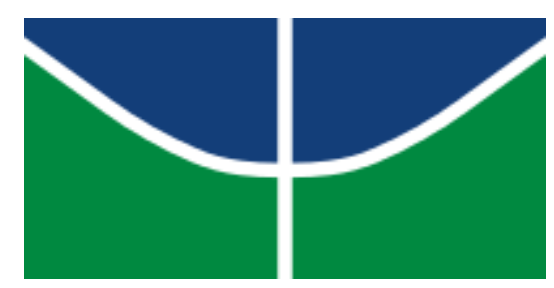

UNIVERSIDADE DE BRASÍLIA

INSTITUTO DE HUMANAS

PROGRAMA DE PÓS GRADUAÇÃO EM HISTÓRIA - PPGHIS

CECÍLIA SIQUEIRA CORDEIRO

LIBERDADE RELIGIOSA NA CONSTITUINTE DE 1823: ATORES E DEBATES

BRASÍLIA, 

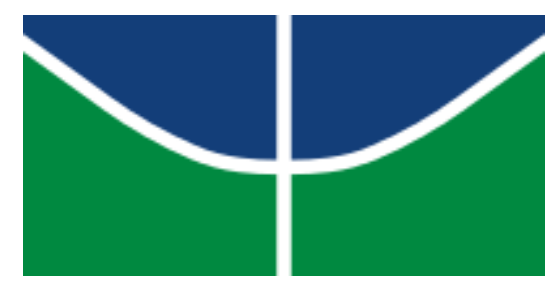

UNIVERSIDADE DE BRASÍLIA

INSTITUTO DE HUMANAS

PROGRAMA DE PÓS GRADUAÇÃO EM HISTÓRIA - PPGHIS

\author{
CECÍLIA SIQUEIRA CORDEIRO
}

\title{
LIBERDADE RELIGIOSA NA CONSTITUINTE DE 1823: ATORES E DEBATES
}

Dissertação apresentada ao Programa de Pós-

Graduação em História - Área de Concentração:

Sociedade, cultura e política. Linha de pesquisa:

Cultura, política e identidades da Universidade de Brasília para a obtenção do título de Mestre em História.

Orientadora: Prof. ${ }^{a}$ Dr. ${ }^{a}$ Diva do Couto Gontijo Muniz

BRASÍLIA, 


\section{CECÍLIA SIQUEIRA CORDEIRO}

\section{LIBERDADE RELIGIOSA NA CONSTITUINTE DE 1823: ATORES E DEBATES}

Dissertação apresentada ao Programa de Pós-

Graduação em História - Área de Concentração:

Sociedade, cultura e política. Linha de pesquisa:

Cultura, política e identidades da Universidade de Brasília para a obtenção do título de Mestre em História.

BANCA EXAMINADORA

Prof. ${ }^{a}$ Dr. ${ }^{a}$ Diva do Couto Gontijo Muniz (PPGHIS-UnB - orientadora)

Prof. ${ }^{\text {a }}$ Dr. ${ }^{\text {a }}$ Maria Elizabeth Ribeiro Carneiro (UFU)

Prof. ${ }^{\text {a Dr. }}{ }^{\text {a }}$ Tereza Cristina Kirschner (PPGHIS-UnB)

Prof $^{a}$ Dr. $^{a}$ Léa Maria Carter Iamashita (PPGHIS-UnB - Suplente)

BRASÍLIA, 


\section{Agradecimentos}

Em outubro de 2013 recebi, com grande alegria, a notícia de que havia sido aprovada no Mestrado em História da UnB. A partir de então iniciou-se um período de muito conhecimento e aprofundamento de um tema que já me acompanhava desde a monografia da graduação. Ao final de cada aula, sentia-me realizada e plena com a formação que escolhi para a vida. Dois anos e alguns percalços depois, concluo essa dissertação com a sensação de dever cumprido. Mais uma etapa acadêmica se encerra com a certeza de que amadureci, profissional e pessoalmente.

Não poderia deixar de agradecer às pessoas que, de uma forma ou de outra, me ajudaram a trilhar este caminho e a concluir este trabalho. Em primeiro lugar, gostaria de agradecer imensamente a meus pais pelo apoio incondicional, pela confiança e pelo amor que recebo todos os dias. Sou grata por cada incentivo - seja um sanduíche para "ajudar a inspirar a escrita", seja o patrocínio de livros e congressos - e cada exemplo que vocês me passam diariamente, demonstrando o valor do trabalho e da dedicação. Estendo esse agradecimento a toda a minha família que, mesmo longe, torce por mim. Em especial agradeço à minha avó Yara por ser meu dicionário de sinônimos preferido e ao meu namorado Thiago pelos momentos de felicidade e riso entre um capítulo e outro.

À minha orientadora, professora Diva. Já são alguns anos trabalhando juntas e a cada dia que passa admiro ainda mais a sua coragem, competência e dedicação. Sou grata por todos os conselhos e sugestões, sutilezas que são fruto de sua vasta experiência e que, com toda a certeza, fazem enorme diferença na formação de um aluno. Um grande exemplo de professora, historiadora e mulher que tive a sorte de conviver.

Aos demais professores e funcionários do PPGHIS-UnB, por disporem de todo o seu conhecimento e solicitude, ajudando-me a cultivar o gosto pela História. Aos colegas da pós, por dividirem comigo as angústias e alegrias de ser uma mestranda, as aflições dos prazos e as emoções de enviar um artigo no último instante.

Aos amigos e amigas que fiz por conta da História e que faço questão de levar comigo para a vida toda. Em especial, ao melhor time de Imagem e Ação de Brasília, capaz de adivinhar a mímica de qualquer presidente brasileiro em poucos segundos. Às "paçaras", amigas de longa data, que aguentam as minhas problematizações quase diárias, que estiveram ao meu lado quando mais precisei e que produzem os melhores e mais vergonhosos memes.

Meus mais sinceros agradecimentos a todos e todas vocês. 


\section{Resumo}

O presente estudo propõe-se a analisar os debates acerca da liberdade religiosa na Assembleia Geral, Legislativa e Constituinte do Império do Brasil de 1823, bem como identificar os seus principais atores políticos. Tais debates serão historicizados considerando-se o tempo histórico que os presidem, ou seja, admitindo-os dentro de uma cultura política comum partilhada por seus atores. Essa cultura política, por sua vez, insere-se nas "mitigadas Luzes portuguesas" e no campo político do liberalismo lusobrasileiro, considerado, à primeira vista, ambíguo. Nesse sentido, os deputados da primeira experiência parlamentar brasileira admitiam e conciliavam, de forma mais ou menos tensionada, elementos modernos - como a noção de representação nacional - com vestígios, práticas e liturgias do Antigo Regime - como a manutenção do catolicismo como religião oficial por excelência, única mantida pelo Estado. Assim, admitia-se uma razoável liberdade religiosa, estendida apenas às comunhões cristãs, fruto de uma lógica pragmática e utilitarista que prezava pela migração de "estrangeiros úteis" ao país.

Palavras-chave: Liberdade religiosa. Assembleia Constituinte de 1823. Liberalismo. Elites Políticas. 


\section{Abstract}

The present study proposes to analyze the debates surrounding religious freedom in the General, Legislative and Constituent Assembly of the Brazilian Empire, in 1823, and to identify its main political actors. These debates will be historicized, considering the historical time that presides, that is, admitting them whitin a common political culture shared by its actors. This political culture, on the other hand, is inserted in the "mitigated portuguese Lights" and the luso-brazilian political liberalism field, considered, at first sight, ambiguous. In this sense, the members of the first brazilian parliamentary experience admitted and conciliated, in a more or less tensioned way, modern elements such as the notion of national representation - with traces, practices and liturgies of the Old Regime - such as maintaining catholicism as the official religion by excellence, the only maintained by the state. Thus, it was admitted a reasonable religious freedom, extended only to christian communions, the result of a pragmatic and utilitarian logic that valued the migration of "useful foreigners" to the country.

Keywords: Religious Freedom. Constituent Assembly of 1823. Liberalism. Political Elites. 


\section{Sumário}

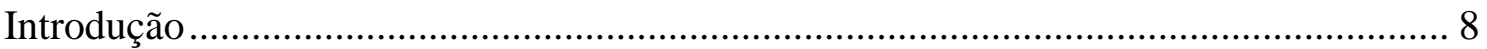

Capítulo 1: Modernidade e tradição: a experiência de uma "Assembleia brasílica"...... 15

“Cortes e Constituição!”: o grito que ecoou por todo o Império luso ...................... 16

As “novas" do Porto chegam ao Brasil ................................................................. 20

A tumultuada regência de d. Pedro................................................................ 35

O fim da cooperação entre "irmãos": os decretos das Cortes................................ 39

Os brasileiros clamam antes por uma "Assembleia brasílica" do que pela

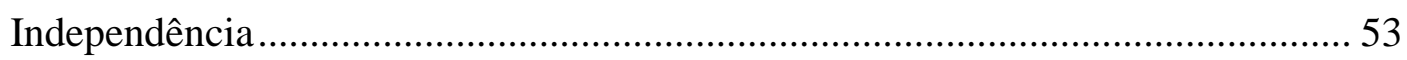

Capítulo 2: Os atores dos debates sobre a liberdade religiosa na Constituinte de 1823. 64

As elites políticas no contexto da Independência e na construção do edifício legal e

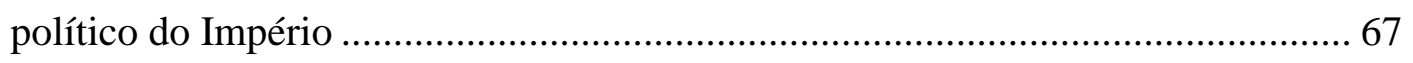

Os espectros políticos dos atores da Constituinte de 1823 .................................. 88

Capítulo 3: Os debates sobre liberdade religiosa na Constituinte ............................... 114

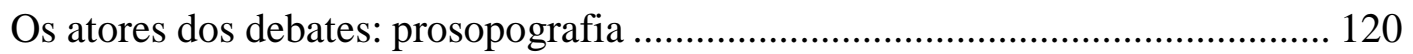

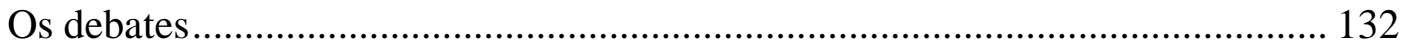

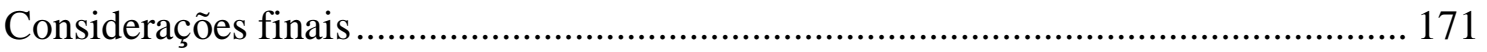

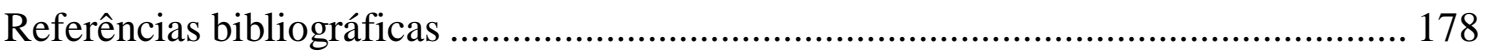




\section{Introdução}

Quando para qualquer matéria se pode arrastar o nome de liberdade, inflamam-se logo os espíritos. ${ }^{1}$

A Igreja Católica constitui uma das instituições capitais do mundo Ocidental. Seu papel estruturante, no entanto, manteve-se relativamente intocado desde os seus primórdios até o crepúsculo do século XVIII, quando eclodiram a Revolução Francesa (1789) e as demais revoluções liberais. Assim, a emergência do século XIX se deu em meio à distância cada vez maior que foi sendo estabelecida entre, de um lado, a religião - e por conseguinte a Igreja Católica - e, de outro, a razão, “ou a capacidade dos homens agirem e transformarem o ambiente em que vivem"2.

É bem verdade que a Igreja católica enfrentara desde sua institucionalização lutas, confrontos, questionamentos e cismas internos e externos. Talvez um dos mais duros golpes sofridos tenha ocorrido no século XVI, com a chamada Reforma Protestante e seus desdobramentos. Com a ascensão da doutrina do direito divino dos reis e com estes tornando-se absolutos por quase toda a Europa, a Igreja foi sendo esvaziada de sua histórica função estruturante. "O absolutismo reduz a Igreja a funções meramente decorativas", criticaria em 1940 o padre Miguel de Oliveira, autor de História Eclesiástica de Portugal. Não por acaso, foi naquele contexto que o regalismo - ou a ingerência do Estado nos assuntos da Igreja - ganha força, sobretudo na França, sendo apoiado inclusive pelo clero nacional: data de 1682 a Declaração do clero galicano $^{4}$ sobre o poder eclesiástico que negava ao Papa todo o direito sobre os assuntos temporais na França e reafirmava a autoridade absoluta de Luís XIV.

\footnotetext{
${ }^{1}$ João Severiano Maciel da Costa, Marquês de Queluz, em discurso proferido no Senado em 10 de junho de 1828 apud RIBEIRO, Gladys Sabina; PEREIRA, Vantuil. O Primeiro Reinado em revisão. In: GRINBERG, Keila; SALLES, Ricardo (orgs.). O Brasil Imperial, volume I: 1808-1831. Rio de Janeiro: Civilização Brasile-+ ira, 2009, p. 138.

${ }^{2}$ NEVES, Guilherme Pereira das. A religião do império e a Igreja. In: GRINBERG, Keila e SALLES, Ricardo (orgs.). O Brasil Imperial..., op. cit., p. 379.

${ }^{3}$ OLIVEIRA, Miguel de. História Eclesiástica de Portugal. $2^{\text {a }}$ ed. Lisboa: União Gráfica, 1948, p. 286.

${ }^{4}$ Galicanismo é o nome que se dá para a tendência do clero francês em afirmar a hegemonia do Estado sobre os assuntos da Igreja. O auge deste movimento acontece ao longo do reinado de Luís XIV (16431715), onde o clero nacional, liderado pelo bispo Jacques Bossuet (1627-1704), redige uma declaração reduzindo a autoridade da Santa Sé no território francês.
} 
Contudo, até então tratavam-se de conflitos de jurisprudência entre a autoridade papal e monárquica, em razão de a Igreja ser uma instituição universal que, por definição, "desconhece" as fronteiras nacionais. É somente a partir da Revolução Francesa e da atmosfera intelectual do Iluminismo que a Igreja passa a ser profundamente questionada. O padre Miguel de Oliveira descreveria esse momento histórico sem esconder o seu desgosto:

\begin{abstract}
Morto Luís XIV, formou-se uma espécie de conjuração geral, não só contra a Igreja, mas contra o próprio Cristianismo. Durante a menoridade de Luís XV, a Regência abre os salões e organiza festas em que pontificam os chamados "filósofos", que se entregam a todas as excentricidades intelectuais e morais: Voltaire, Montesquieu... (...) Veio logo a Revolução Francesa (1789) como tempestade resultante de duas nuvens que se encontraram - a incredulidade e a licença de costumes -, para destruir o que os "filósofos" chamavam o fanatismo e o despotismo: a Religião e a Monarquia (...) $\mathrm{O}$ espírito revolucionário conquista todos os países. A Igreja parece definitivamente arruinada. ${ }^{5}$
\end{abstract}

A crescente modernização do mundo Ocidental tendeu à secularização e o papel outrora exercido pelos religiosos passou gradativamente a ser atribuído a cientistas e burocratas, na medida em que os próprios limites geográficos do Globo se expandiram, a partir da descoberta da América. Essas transformações levaram à substituição das formas de compreensão do mundo, que, mais do que nunca, passaram a buscar inspiração no passado. Hans-Georg Gadamer, em 1949, escreveria sobre o "aparecimento de uma consciência propriamente histórica":

Nenhuma das ciências modernas, nem mesmo aquelas que fomentaram tão poderosamente a nossa consideração da natureza e a nossa instalação técnica do mundo equipararam-se em termos de significação revolucionária à formação do sentido histórico por meio da consciência histórica. Saber a si mesmo, historicamente, ser com consciência um ente condicionado, essa verdade do relativismo histórico é de uma seriedade vital e frutífera, se ela não é pensada apenas academicamente, mas praticada politicamente. ${ }^{6}$

No Brasil oitocentista, particularmente no caso de sua primeira experiência parlamentar, a Assembleia Constituinte de 1823, os debates acerca da liberdade religiosa,

\footnotetext{
${ }^{5}$ OLIVEIRA, Miguel de. op. cit., p. 286-287.

${ }^{6}$ GADAMER, H-G. Os limites da razão histórica. In: Hermenêutica em retrospectiva (1949). Petrópolis: Editora Vozes, 2007 apud NEVES, Guilherme Pereira das. “A religião do império...”, op. cit., p. 381.
} 
bem como seus atores, apontam-nos para a emergência daquelas transformações e cobram-nos sua historicização. Afinal, é justamente no contexto da Independência que a disputa em torno da montagem do edifício legal e político do Estado imperial é travada. Dois universos mentais disputavam entre si: aqueles que eram favoráveis à liberdade de culto - já impregnados pela literatura antirreligiosa e liberal do século - e aqueles que não o eram - e que ainda viam na religião católica o fundamento moral da sociedade.

No referido debate na Constituinte, não há como ignorar o tempo histórico que o preside, pressionado por embates decorrentes de diferentes espaços de experiências e horizontes de expectativas. Essa relação entre experiências e expectativas, como teorizou Reinhart Koselleck ${ }^{7}$, é assimétrica e tensionada, uma vez que novas experiências - como a vinda da família Real para o Brasil em 1808, a elevação do país ao posto de Reino Unido em 1815, a Revolução do Porto em 1820 e a Independência em 1822 - modificaram as projeções de futuro, bem como os usos que os contemporâneos faziam do passado. Em momentos de significativas mudanças políticas, portanto, passado e futuro tornam-se passíveis de diferentes leituras e interpretações, tornando-se objetos de lutas de representação. Um palco privilegiado dessas lutas de representação é a Assembleia Geral, Legislativa e Constituinte de 1823.

Nesse sentido, voltamo-nos, no capítulo 1, para as transformações que tiveram lugar no Império luso-brasileiro no início do século XIX. Deparamo-nos com um cenário de "mitigadas luzes" e de um liberalismo limitado, à primeira vista paradoxal, na medida em que a introdução de elementos da modernidade - como a instituição de Cortes Constituintes, a noção de representantes do povo e o culto às liberdades civis, políticas e individuais - conviviam com tradições e figuras representativas do Antigo Regime, como a manutenção da monarquia - se bem que constitucional - e da Igreja. Ou seja, mesmo após as agitações liberais que sacudiram Portugal e Brasil, o Trono e o Altar continuavam intactos, concebidos como elementos que garantiam a coesão e mesmo a sustentação daquela sociedade. É por isso que os panfletos e cartazes revolucionários davam vivas tanto à Constituição e às liberdades modernas, quanto à "el rei constitucional", ao "príncipe real" e à "santa religião".

No Império luso-brasileiro, diferentemente do que ocorrera na França revolucionária, as elites políticas, a tropa e o povo clamariam por reformas e regeneração,

\footnotetext{
7 KOSELLECK, Reinhart. “'Espaço de experiência' e 'horizonte de expectativa': duas categorias históricas". In: . Futuro passado: contribuição à semântica dos tempos históricos. Rio de Janeiro: Contraponto/PUC-Rio, 2006, p. 305-328.
} 
jamais por revolução, tendo em vista o contexto histórico em que se inseriam. A Europa vivia uma ação/reação restauradora com a Santa Aliança, e a fase do "terror" da Revolução Francesa ainda assombrava o imaginário da época. Sendo assim, o movimento vintista que eclodiu no Porto e se estendeu ao Brasil tinha um caráter regenerador. Não havia mais lugar para o absolutismo e o despotismo - este último identificado muito mais com o ministério do que com o próprio monarca, que ainda era visto como grande responsável pela felicidade e tranquilidade pública. Reformas faziam-se necessárias e urgentes, e a Coroa não teve outra alternativa a não ser ceder uma parcela de sua soberania a ser partilhada com o povo e com o poder Legislativo que se formava.

$\mathrm{O}$ fato de os liberais luso-brasileiros não atacarem a figura do rei, mas a de seus ministros, considerados inescrupulosos e ineptos porque o aconselhavam mal, e de continuarem vendo na religião católica o fundamento moral da sociedade - uma vez que não defendiam, sob nenhuma hipótese, o estado laico - caracterizou o que chamamos de “mitigadas Luzes” portuguesas. Esse Iluminismo praticado em Portugal e, por extensão, no Brasil, apresentava características singulares, disposto, no que diz respeito à autoridade real, a aparar algumas arestas do poder absoluto, e, quanto à autoridade eclesiástica, admitir uma razoável liberdade religiosa, desde que reservadas as prerrogativas de exterioridade do culto e de oficialidade à religião católica, religião do Estado por excelência. Evidencia-se, portanto, que a obra de secularização política, tão característica do século XIX, ainda se encontrava incompleta durante o processo de emancipação política e da construção do edifício político e legal do Brasil.

Os atores que levaram a cabo esse liberalismo, sem dúvida constitucionalista, de inícios da década de 1820 são o tema do capítulo 2 desta dissertação. Ao longo das profundas mudanças políticas processadas nesse curto período de tempo (1820-1824), percebemos a formação de fluídas alianças que defendiam alguns projetos políticos e alternativas de futuro para o Brasil. O leque de possibilidades que se abriu neste momento, vencidos os arroubos absolutistas de alguns ministros e conselheiros de d. João, devidamente despachados para Portugal, permitiu que os atores políticos se posicionassem mais à esquerda, ao centro ou à direita do espectro político liberal. Era o triunfo do liberalismo constitucionalista: haviam-se convocado Cortes Gerais em Lisboa e uma Assembleia Constituinte no Brasil. Nesse sentido, identificamos dentro do campo político do liberalismo posições ora mais radicais, ora mais conservadoras, ou ainda moderadas - no sentido de que há um trânsito entre esses dois extremos, muitas vezes praticado em um mesmo discurso, que assume ares conciliadores. Vale ressaltar, campo 
político deve ser aqui entendido na perspectiva de Bourdieu, qual seja, como "um microcosmo autônomo no interior do macrocosmo social",

como um campo de forças, cuja necessidade se impõe aos agentes que nele se encontram envolvidos, e como um campo de lutas, no interior do qual os agentes se enfrentam, com meios e fins diferenciados conforme sua posição na estrutura do campo de forças, contribuindo assim para a conservação ou a transformação de sua estrutura. ${ }^{9}$

Assim sendo, os atores dos debates sobre liberdade religiosa na Assembleia Constituinte de 1823 empreenderam lutas de representações dentro do campo político do liberalismo, posicionando-se como contrários ou favoráveis à liberdade de culto. Conservavam alguns aspectos identificados com o antigo sistema, como a manutenção de uma religião oficial e a visão de que a Igreja era capaz de civilizar e moralizar a sociedade, estando, portanto, fora de cogitação a opção de um estado laico. Ao mesmo tempo, transformavam estruturas ao admitirem a liberdade religiosa para brasileiros, ainda que, salvo as comunhões cristãs, reservada ao culto doméstico e particular, e ao condenarem qualquer tipo de perseguição ou violência por motivo de crença pessoal.

Os debates sobre a liberdade religiosa propriamente ditos foram tratados no capítulo 3, no esforço de apreender melhor a posição de seus atores. Nenhum deputado constituinte, representante do povo brasileiro e membro da elite política do país, mostrase interessado em abdicar da condição de súdito de uma nação católica. Pelo contrário, aqueles que se posicionam a favor da liberdade de culto fazem questão de explicitar em seus discursos que são "mui católicos". Há também uma crença de que tal liberdade não seria uma demanda dos "povos do Brasil", já que, na visão de praticamente todos os preopinantes, a nação formava-se inteiramente por católicos. Preocupavam-se, porém, com os futuros imigrantes e seus descendentes - "estrangeiros úteis" - que viessem a se instalar no país, tanto por motivos de povoação do território quanto de substituição futura para a mão de obra escrava.

A locomotiva das transformações estruturantes e liberais do século XIX já havia imprimido sua marca no mundo, de forma que as elites políticas brasileiras acabaram, em maior ou menor grau, embarcando em seus vagões. Por isso, vemos inúmeros discursos exaltando a consciência e o pensamento como verdadeiros santuários, os quais nenhum

\footnotetext{
${ }^{8}$ BOURDIEU, Pierre. O campo político. In: Revista Brasileira de Ciência Política, no ${ }^{\circ}$. Brasília: julho de 2011, p. 195.

${ }^{9}$ BOURDIEU, Pierre. Razões práticas: sobre a teoria da ação. $9^{\text {a }}$ ed. Campinas: Papirus, 1996, p. 50.
} 
poder humano poderia penetrar. A liberdade religiosa, embora escandalizasse alguns deputados, foi aprovada como direito individual dos brasileiros porque a Assembleia entendeu que a relação entre a criatura e o Criador é uma relação íntima e pessoal, portanto, inatingível pelo Estado. Nenhum cidadão poderia ser forçado a professar a religião católica, tampouco a Constituinte apoiaria que existissem perseguições e torturas como aconteciam nos "hórridos tempos" da Inquisição. As "Luzes" do século não permitiam tal disparate. Porém, quando se entrou em discussão e votação os artigos 14, 15 e 16 do projeto constitucional, referentes à liberdade religiosa, percebe-se que a grande influência da Igreja católica, tradição herdada do Antigo Regime, prevalecia, mesmo entre os espíritos mais ilustrados.

O artigo 14 delimitaria a liberdade religiosa, estendendo-a apenas às seitas cristãs, nomeadamente, ao catolicismo e protestantismo. Este, por sua vez, já era permitido no Brasil desde os tratados firmados com a Inglaterra em 1810, admitido em razão das fortes relações comerciais e econômicas entre os dois países. Concediam-se direitos políticos aos praticantes dessas seitas, o que gerou intenso debate entre os deputados. Já o artigo 15 promulgava que as demais religiões seriam apenas toleradas, inibindo-se os direitos políticos daqueles que as professassem. Vale ressaltar que as "demais religiões" a que se referiam seriam aquelas não derivadas do cristianismo, como o judaísmo, islamismo e outras "seitas heréticas", as quais chamavam "Idolatrias". Em seus discursos, os deputados ignoravam as religiões de matriz africana que, sem dúvida, eram praticadas Brasil a fora por muitos escravos e também por muitos livres e libertos, negros e mestiços de ambos os sexos. Como já foi assinalado, os constituintes consideravam-se parte de uma nação inteiramente católica, que não contava no seio de sua grande família com uma só religião diferente do catolicismo. Nesse sentido, o artigo 16 não levantou nenhuma contestação por parte dos parlamentares, uma vez que estabelecia o óbvio: a religião católica continuaria sendo a religião oficial do Império e única mantida pelo Estado.

Ao fim e ao cabo, após muitas emendas aos artigos 14 e 15 e quase 70 intervenções, estabeleceu-se que tratar-se-iam dos direitos políticos na parte da Constituição para isso destinada - que, porém, jamais chegou a ser discutida, haja vista a dissolução da Assembleia poucos dias depois. Quanto à liberdade religiosa, permitia-se o culto externo, em Igrejas e templos, apenas à comunhão oficial. As religiões cristãs poderiam ser professadas em recintos para isso destinados, sem forma exterior de templo (por exemplo, campanários), como já se havia estabelecido em 1810 com relação aos 
protestantes ingleses. Já às religiões não cristãs reservava-se o culto doméstico, sendo essas toleradas caso não fossem "destrutivas da moral" e dos bons costumes.

Nesse contexto, as discussões sobre a liberdade religiosa que tiveram como palco a primeira experiência parlamentar do Brasil evidenciavam a coexistência, mais ou menos tensionada, de elementos típicos do Antigo Regime e da modernidade, identificada principalmente no liberalismo. Os atores que se posicionaram nos debates eram filhos de seu tempo - e por conta disso apresentavam algumas divergências, principalmente com relação aos "níveis" do campo político do liberalismo, professado por todos. Esses atores, que compartilhavam um repertório político abrigado sob uma cultura política comum, aqui entendida como "pressupostos socialmente partilhados a respeito de comportamentos políticos" 10 , ora se aproximam, ora se afastam do objetivo principal de montagem do edifício do Estado imperial: o desafio de acabar com os entraves coloniais, empreendendo as reformas necessárias, sem, contudo, fazer tábula rasa de todo o passado.

${ }^{10}$ GRAHAM, Sandra Lauderdale. O Motim do Vintém e a Cultura Política do Rio de Janeiro, 1880. In: Revista Brasileira de História: Reforma e Revolução. São Paulo: ANPUH/Marco Zero, v. 10, nº. 20, 1990, p. 212. 


\title{
Capítulo 1: Modernidade e tradição: a experiência de uma "Assembleia brasílica"
}

\author{
Quando o Brasil acordou \\ Do sono em que jazia, \\ Já no Douro se dizia: \\ - O Despotismo acabou. \\ O Brasil logo entoou \\ Vivas à Religião, \\ À hemisférica união \\ A el rei constitucional \\ Ao príncipe real \\ À feliz Constituição. ${ }^{1}$
}

Aos 14 de maio de 1822, o jornal baiano $O$ Espelho brindava seus leitores com décimas alusivas à "questão do tempo", ou seja, à regeneração constitucional pela qual passava o mundo luso. Esses versos exprimem, em poucas linhas, as características peculiares e aparentemente paradoxais do liberalismo luso-brasileiro. Davam-se vivas à religião e aos representantes da monarquia, elementos constitutivos do que se convencionou chamar de Antigo Regime, mas também à Constituição, que passava a exprimir o espírito da racionalidade e da modernidade, enfim, das "Luzes" que se propagavam desde a Revolução Francesa $(1789)^{2}$.

Foi nesse cenário de "mitigadas Luzes" ou de um liberalismo limitado, conforme estudado por diversos autores ${ }^{3}$, que se deram o processo de emancipação política do Brasil e os primeiros passos da construção do edifício político e legal do Primeiro Reinado. Compartilhando das reflexões de Tereza Kirschner de que o século XIX no Brasil inaugurou "uma nova relação dos contemporâneos com o passado em função das

\footnotetext{
1 O Espelho, no 51, 14 de maio de 1822 apud NEVES, Lúcia M. Bastos Pereira das. Corcundas $e$ constitucionais: a cultura política da Independência (1820-1822). Rio de Janeiro: Revan/FAPERJ, 2003, p. 152.

${ }^{2}$ Para os usos antigos e modernos da palavra Constituição, cf. NEVES, Lúcia M. Bastos Pereira das. "Constituição: usos antigos e modernos de um conceito no Império do Brasil". In: CARVALHO, José Murilo de; NEVES, Lúcia M. Bastos Pereira das (orgs.). Repensando o Brasil do Oitocentos: cidadania, política e liberdade. Rio de Janeiro: Civilização Brasileira, 2009, p. 181-205.

${ }^{3}$ Cf. COSTA, Emília Viotti da. Da Monarquia à República: momentos decisivos. 9a ed. São Paulo: UNESP, 2010; RODRIGUES, José Honório. Independência: revolução e contra-revolução. A evolução política. v. 1. Rio de Janeiro: Francisco Alves, 1975; NEVES, Lúcia M. Bastos Pereira das. op. cit.; OLIVEIRA, Cecília Helena L. de Salles. A astúcia liberal. Relações de mercado e projetos políticos no Rio de Janeiro (1820-1824). Bragança Paulista: EDUSF/Ícone, 1999.
} 
transformações processadas no presente" ${ }^{\text {, }}$ pretendemos analisar como novas experiências - como a vinda da Família Real para o Brasil em 1808, a elevação do país ao posto de Reino Unido em 1815, as repercussões da Revolução do Porto de 1820 e a Independência em 1822 - engendraram as projeções de futuro, bem como os usos que os contemporâneos faziam do passado. Em momentos de significativas mudanças políticas, portanto, passado e futuro tornam-se objetos de lutas de representações, configurando a assimétrica e tensa relação entre espaço de experiências e horizonte de expectativas, conforme teorizou Reinhart Koselleck ${ }^{5}$.

Um palco privilegiado dessas lutas de representações, de embates entre "universos mentais" distintos - por exemplo, entre aqueles favoráveis à liberdade de culto, já impregnados com a literatura liberal do século, e aqueles que não o eram e que ainda viam na religião o "fundamento moral" da sociedade -, foi a Assembleia Geral, Legislativa e Constituinte do Império do Brasil (1823). Porém, até que a Assembleia tomasse assento, em 3 de maio, que o Projeto de Constituição fosse apresentado, aos 15 de setembro, e que os artigos referentes à liberdade de culto fossem discutidos, a partir de 7 de outubro, vários foram os eventos que contribuíram para as mudanças políticas que transformaram o Brasil em uma nação independente.

\section{“Cortes e Constituição!": o grito que ecoou por todo o Império luso}

Aos 24 de agosto de 1820, eclodia na segunda cidade em importância de Portugal, Porto, um movimento liberal e constitucionalista que "deu início à agonia do Antigo Regime português"7 . Apesar e por conta de a Europa presenciar, no início do século XIX, uma conjuntura restauradora e conservadora representada pela Santa Aliança, a década

\footnotetext{
${ }^{4}$ KIRSCHNER, Tereza Cristina. Um pouco de historiografia: a representação do passado colonial brasileiro a partir da Independência. In: Anais do XXVI Simpósio Nacional de História - ANPUH. São Paulo, julho de 2011, p. 11.

${ }^{5}$ KOSELLECK, Reinhart. Futuro passado: contribuição à semântica dos tempos históricos. Rio de Janeiro: Contraponto/PUC-Rio, 2006.

${ }^{6}$ A expressão foi usada por Guilherme Neves. NEVES, Guilherme Pereira das. "A religião do Império e a Igreja”. In: GRINBERG, Keila; SALLES, Ricardo (orgs.). O Brasil Imperial, volume I: 1808-1831. Rio de Janeiro: Civilização Brasileira, 2009, p. 388.

${ }^{7}$ NEVES, Lúcia M. Bastos Pereira das. op. cit., p. 229. Muitos autores trabalharam a noção de "crise colonial" ou de "crise do antigo sistema", cf. MOTA, Carlos Guilherme (org.). 1822: dimensões. São Paulo: Perspectiva, 1972; COSTA E SILVA, Alberto da (coord.). Crise colonial e Independência: 1808-1830, v. 1. Rio de Janeiro: Objetiva, 2011 (Coleção História do Brasil Nação: 1808-2010, dir. SCHWARTZ, Lilia Moritz); LYRA, Maria de Lourdes Viana. A unidade brasileira: uma questão preliminar no processo de Independência. In: Revista do Instituto de Estudos Brasileiros, vol. 34. São Paulo, 1992, p. 121-138.
} 
de 1820 trouxe um novo ímpeto, se não revolucionário nos moldes da Revolução Francesa, por certo regenerador e reformista. A começar pela Espanha, a onda de revoltas se espalhou também por Portugal e pela Península Itálica.

Segundo nos conta a historiadora Lúcia Neves, as autoridades portuguesas escreviam alarmadas para d. João VI denunciando o crescente ingresso de exemplares da Constituição espanhola em território luso, buscando diligências para prevenir o "contágio das ideias liberais" que encontravam terreno, sobretudo, nas províncias do Norte. Como observou Lesseps, encarregado de negócios da França em Lisboa,

os espíritos fermentam; fala-se mais livremente do que nunca; fazem-se votos de uma mudança próxima; mas Lisboa não será o lugar de onde partirá a primeira explosão. As províncias do Norte, cuja opinião parece ter sido mais fortemente levada pelo exemplo [espanhol], meditam surdamente em segui-lo e tudo anuncia que a tal se dispõem. Escritos, reuniões clandestinas, descontentamento ostensivo, tais são os prelúdios de um código que em breve se propagará para o Sul. ${ }^{8}$

Desde a vinda da Corte para o Rio de Janeiro, em 1808, Portugal encontrava-se em uma posição, no mínimo, desconfortável, percebendo-se na "situação de colônia de uma colônia"9 . Desgastadas após a resistência ao avanço napoleônico e descontentes com os mandos e desmandos da Inglaterra ${ }^{10}$ e de seu general Beresford, as elites lusas reuniram-se com as tropas no movimento que ficou conhecido como vintismo. Contribuíram para tal descontentamento a situação humilhante de Portugal, que desde a abertura dos portos do Brasil perdera os lucros do comércio colonial, afundando-se em uma grave crise econômica. O "estado de coisas" em que o país se encontrava agravou a insatisfação das elites locais em relação ao Antigo Regime e ao Estado absolutista, que se mostrava incapaz de "elaborar uma estratégia política que articulasse os interesses da

\footnotetext{
${ }^{8}$ Ofício de Lesseps, 27 de março de 1820 apud NEVES, Lúcia M. Bastos Pereira das. op. cit., p. 232.

${ }^{9}$ RODRIGUES, José Honório. Independência... A evolução política, v. 1. op. cit., p. 69.

${ }^{10}$ Segundo o historiador português Valentim Alexandre, o sentimento nacionalista e a reação contrária à presença inglesa só surgem em Portugal a partir de 1815. Até a derrota definitiva das tropas napoleônicas na Europa, a imprensa e burguesia lusas experimentaram uma "anglomania", onde a intervenção inglesa era vista como uma "grande empresa comum", permitindo uma "nova época de prestígio e grandeza nacional" a Portugal. O "desencanto" viria após o país obter "a menor das indenizações" no Congresso de Viena: "Longe de ganhar uma posição de maior relevo no sistema internacional, Portugal aparecia manifestamente como um país sob a tutela britânica". Sobre o assunto, cf. ALEXANDRE, Valentim. "O nacionalismo vintista e a questão brasileira: esboço de análise política". In: PEREIRA, Miriam Helpern; FERREIRA, Maria de Fátima Sá e Melo; SERRA, João B. (coords.). O Liberalismo na Península Ibérica na primeira metade do século XIX, v. 1. Lisboa: Sá da Costa, 1982, p. 287-307.
} 
antiga metrópole" ${ }^{\prime 1}$. Escrevendo em 1912, Manuel Gomes de Carvalho assim expôs a situação degradante de Portugal:

\begin{abstract}
Em consequência da invasão francesa e da abertura dos portos do Brasil às nações amigas, a miséria no Reino ia em crescimento assustador. Cada ano assinalava nova redução na Marinha; aumentava a importação dos gêneros de primeira necessidade, a começar pelo trigo; fechavam-se as fábricas, os produtos vencidos da concorrência inglesa no ultramar, e os operários, famintos, tornavam-se mendigos ou ladrões. Em 1820 a penúria atingia o extremo. Esgotado inteiramente, o erário não pagava aos funcionários públicos (...), à miséria ajuntava-se a humilhação. Humilhação no Exército, onde a presença de oficiais europeus fazia acreditar na incapacidade do português para defender só a terra natal; humilhação em todas as classes, porque a gloriosa nação se achava reduzida à colônia do Brasil, constituído o centro da monarquia, por abrigar o soberano. ${ }^{12}$
\end{abstract}

O descontentamento geral e o entusiasmo com que os vizinhos espanhóis haviam acolhido o juramento da Constituição de Cádiz pelo rei, em março de 1820, induziram as elites locais, auxiliadas pela guarnição, "a se revoltarem em 24 de agosto contra o absolutismo, com programa verdadeiramente moderado"13. Era urgente a realização de reformas. Cortes e Constituição transformaram-se, então, nos "símbolos mágicos para a solução de toda a crise portuguesa" ${ }^{14}$, uma vez que o despotismo foi apontado como a principal causa do declínio português. Despotismo, vale ressaltar, identificado no ministério, e não na figura do monarca, que era visto mais como "uma vítima nas mãos de ministros inescrupulosos, que o aconselhavam mal e o enganavam" ${ }^{15}$. Pretendia-se articular

a monarquia a uma Constituição que estabelecesse limites ao poder real e garantisse direitos e liberdades civis e políticas aos cidadãos do Império. Pretendia-se, por essa via, entre outras exigências, contestar o absolutismo representado por d. João VI e o "despotismo" exercido por ministros, por conselheiros e pela Corte radicada no Rio de Janeiro desde $1808 .{ }^{16}$

\footnotetext{
${ }^{11}$ NEVES, Lúcia M. Bastos Pereira das. op. cit., p. 234.

12 CARVALHO, Manuel E. Gomes de. Os deputados brasileiros nas Cortes Gerais de 1821. Brasília: Senado Federal, 1979, p. 7.

13 Idem.

${ }^{14}$ NEVES, Lúcia M. Bastos Pereira das. op. cit., p. 236.

15 Ibidem, p. 235.

16 OLIVEIRA, Cecília Helena L. de Salles. "Repercussões da revolução: delineamento do império do Brasil, 1808/1831”. In: GRINBERG, Keila; SALLES, Ricardo (orgs.). op. cit., p. 18-19.
} 
Fruto do liberalismo moderado ou "mitigado" da Ilustração portuguesa, o movimento clamava por reformas e por regeneração nacional, jamais por revolução, já que esta levaria inevitavelmente ao caos e à anarquia - o exemplo da fase do "terror" da Revolução Francesa ainda assombrava o imaginário das elites da época. É por isso que o tom dos periódicos, dos panfletos e até dos discursos dos líderes do movimento preza pela moderação e pela manutenção da ordem e tranquilidade públicas, como avalia Lúcia Neves:

\begin{abstract}
Mesmo após o movimento do Porto, evitava-se tanto a linguagem quanto atos revolucionários, preferindo-se apresentar as novas ideias sob uma roupagem regeneradora. No Manifesto da Nação portuguesa aos soberanos povos da Europa, afirmava-se que os acontecimentos em Portugal não tinham raízes na ideologia da Revolução Francesa, só pretendendo o país a "restituição de suas antigas e saudáveis pretensões". Reconhecia, contudo, que as instituições deviam ser "corrigidas e aplicadas segundo as Luzes do século e as circunstâncias do mundo civilizado". ${ }^{17}$
\end{abstract}

Nesse sentido, a proposta das elites burguesas ${ }^{18}$ envolvidas na regeneração portuguesa, embora influenciada pelas "Luzes do século", não negava nem a monarquia, nem a religião católica. Gomes de Carvalho destaca que os revoltosos

não pregavam a república nem mesmo a substituição da monarquia, a despeito de haver o rei abandonado a nação, em fuga precipitada para o Brasil; ao contrário, referiam-se a ele com expressões de respeito, simpatia e dedicação, que certamente não merecia o chefe que já não podia justificar sua ausência da pátria. Manteriam a religião católica. O que queriam era a participação do povo nos negócios públicos. ${ }^{19}$

Tratava-se, portanto, apenas de reformar as instituições vigentes, sendo essas reformas garantidas legalmente com a elaboração da nova Constituição e com o retorno do rei a Portugal a fim de que o país recuperasse a posição de centralidade no/do Império Português. Também não se falava em fragmentação do Império ou separação de Portugal e do Brasil ${ }^{20}$,já que se tratavam de duas nações “irmãs” que deveriam permanecer unidas.

\footnotetext{
${ }^{17}$ NEVES, Lúcia M. Bastos Pereira das. op. cit., p. 236.

${ }^{18}$ Para muitos autores, os grupos que encabeçaram a regeneração portuguesa foram, primeiramente, os grandes comerciantes e a burguesia portuguesa, prejudicados com o fim do exclusivismo comercial, apoiados pela tropa e, por fim, por todos os setores da sociedade, insatisfeitos com a redução de Portugal à colônia do Brasil. Cf., por exemplo, LYRA, Maria de Lourdes Viana. A unidade brasileira... op. cit.; ALEXANDRE, Valentim. "O nacionalismo vintista...". op. cit.

${ }^{19}$ CARVALHO, Manuel E. Gomes de. op. cit., p. 7.

${ }^{20}$ Valentim Alexandre, escrevendo sobre a perspectiva dos regeneradores portugueses, afirmaria que estes desejavam a união com o Brasil, embora em “termos diferentes” do que acontecia até então, já que Portugal
} 
As Bases da Constituição política da Nação Portuguesa, juradas por d. João VI ainda no Brasil, são significativas desse projeto:

16. A Nação portuguesa é a união de todos os portugueses de ambos os hemisférios.

17. A sua religião é a católica romana.

18. O seu governo é a monarquia constitucional hereditária, com leis fundamentais que regulem o exercício dos três poderes políticos. $^{21}$

Adotava-se, assim, uma perspectiva de conciliação entre a tradição e algumas exigências da modernidade, operada por meio de uma mudança gradual que não implicava transformações profundas na estrutura da sociedade. Tal conciliação deveria ser conduzida pelo monarca, ainda visto como responsável pelo bem-estar de seus súditos e felicidade pública, numa ótica típica de Antigo Regime. Segundo o historiador português Valentim Alexandre, escrevendo na década de 1980 sobre a perspectiva dos regeneradores,

a simples ausência do rei, personagem sacralizado, reputado a fonte de toda a justiça, provocava mal-estar, que mesmo um jornal liberal como o Campeão Português refletia, quando dizia estarem os portugueses "órfãos", por lhes faltar a "natural proteção do rei". ${ }^{22}$

Sendo assim, as figuras representativas da monarquia, o Trono e o Altar, continuavam intactas mesmo após as agitações do Porto, embora ganhasse espaço, de forma mais ou menos articulada, a moderna noção de soberania do povo, personificada na ideia de representantes da nação e de Cortes constituintes.

\section{As "novas" do Porto chegam ao Brasil}

Quando as notícias da sublevação do Porto chegaram ao Rio de Janeiro, em outubro de 1820, os conselheiros de d. João VI sabiam que reformas se faziam necessárias

não queria continuar sendo uma "simples província" brasileira. A separação passou a ser uma opção
possível somente mais à frente, sem que, contudo, houvesse um "plano nesse sentido: a hipótese é sempre
colocada como alternativa possível, mas indesejável, e de modo nenhum como objetivo a atingir ou sequer
como realidade inelutável". ALEXANDRE, Valentim. "O nacionalismo vintista...". op. cit.
${ }^{21}$ Bases da Constituição Política da Monarquia Portuguesa, aprovadas em 10 de março de 1821 . O
documento serviu provisoriamente de Constituição, sendo elaborado pelos deputados constituintes reunidos
desde janeiro de 1821 em Assembleia, e assentava a substituição das "velhas leis fundamentais" pelo "novo
pacto social", pautado por um legime liberal, disponível em: http://arqnet.pt/portal/portugal/liberalismo/bases821.html. Acesso: 19/11/2015.

22 ALEXANDRE, Valentim. “O nacionalismo vintista...”. op. cit., p. 291. 
- sobretudo para impedir as perturbações revolucionárias -, embora divergissem em alguns pontos cruciais. O ministro dos Negócios, Estrangeiro e da Guerra, Silvestre Pinheiro Ferreira ${ }^{23}$, aconselhou d. João a declarar-se rei constitucional de Portugal, como fizeram “Luís XVIII em França, o príncipe Orange na Holanda, o rei de Witemberg, o imperador da Rússia à Polônia, o rei da Suécia e como prometeu o rei da Prússia nos seus estados", já que essa era a "dominante do tempo", que consistia em "dar alguns privilégios e prerrogativas aos Povos, para consolidarem as suas" ${ }^{24}$. Tratava-se de conceder, pela magnânima bondade do soberano, uma Carta Constitucional, a fim de sanar as inquietações de seus súditos, sem, contudo, ceder aos anseios de convocação de Cortes modernas, que ratificavam a vontade de representatividade da nação.

Postura parecida apresentava o conde de Palmela. Testemunha ocular da Revolução do Porto, Pedro de Sousa e Holstein, mais conhecido como conde de Palmela ${ }^{25}$, chegava à Corte em dezembro de 1820 para assumir a pasta dos Negócios, Estrangeiro e da Guerra. O novo ministro "acalentava o projeto de uma monarquia, com Carta constitucional nos moldes franceses de Luís XVIII, favorável, portanto, ao poder do rei e da nobreza". Acreditava ser esta "a tendência geral das Nações da Europa", sendo melhor "adotá-la o quanto antes, para que o império luso-brasileiro não caísse em desvarios democráticos" ${ }^{26}$, chegando inclusive a oferecer as bases de uma Constituição ao rei onde estava assegurada a participação do monarca no poder Legislativo. Defendia ainda o retorno de d. João VI a Portugal, permanecendo o príncipe herdeiro no Brasil, pois "continuava vendo na antiga metrópole o centro do sistema luso-brasileiro"27.

Por sua vez, Tomás Antônio de Vilanova Portugal ${ }^{28}$, que havia acumulado as pastas dos Negócios, Estrangeiro e da Guerra até a chegada do conde de Palmela, adotava

\footnotetext{
${ }^{23}$ Silvestre Ferreira assumiu o ministério em 26 de fevereiro de 1821, sendo sucedido pelo conde dos Arcos, já ministro da regência de d. Pedro. Para uma breve biografia de Silvestre Ferreira cf. verbete do Arquivo Nacional, disponível em http://linux.an.gov.br/mapa/?p=6525. Acesso: 25/11/2015.

${ }^{24}$ NEVES, Lúcia M. Bastos Pereira das. "O governo de D. João: tensões entre ideias liberais e as práticas do Antigo Regime”. In: CARVALHO, José Murilo de; CAMPOS, Adriana Pereira (orgs.). Perspectivas de cidadania no Brasil Império. Rio de Janeiro: Civilização Brasileira, 2011, p. 211-212.

25 Palmela assumiu o ministério em 20 de dezembro de 1820, sendo sucedido por Silvestre Ferreira. Para uma breve biografia do conde de Palmela, cf. verbete do Arquivo Nacional, disponível em http://linux.an.gov.br/mapa/?p=6520. Acesso: 25/11/2015.

${ }^{26}$ NEVES, Lúcia M. Bastos Pereira das. op. cit., p. 243.

27 Idem.

${ }^{28}$ Vilanova Portugal assumiu o ministério, bem como a presidência do Real Erário, de 30 de novembro de 1817 a 20 de dezembro de 1820, sendo sucedido pelo conde de Palmela. Para uma breve biografia de Vilanova Portugal cf. verbete do Arquivo Nacional, disponível em: http://linux.an.gov.br/mapa/?p=6528. Acesso: 25/11/2015.
} 
uma postura "mais intransigente" 29 . Vilanova Portugal seria o porta-voz de uma corrente que

encarava a sublevação como "um ato de tresloucada temeridade", que devia ser sumariamente sufocado com a ajuda da intervenção militar das potências europeias da Santa Aliança ou com a volta do marechal Beresford para retomar o comando do Exército e restabelecer a ordem. ${ }^{30}$

A saber se a "Sede da Monarquia se há de estar em Portugal ou no Brasil", Vilanova Portugal defendia que deveria haver uma figura real "em cada um destes Continentes" 31 , sendo da opinião que d. Pedro partisse para Portugal e d. João VI permanecesse no Brasil. Desta forma, mantinha a "ilusão de preservar todas as prerrogativas reais na América, sufocando qualquer tentativa revolucionária" 32 . O fato deste ministro permanecer "fiel a seus princípios de não ceder nem um palmo da autoridade real" 33 teria ocasionado sua substituição pelo conde de Palmela, espírito mais ilustrado, que, contudo, viria a ser substituído apenas três meses depois por Silvestre Ferreira, demonstrando a instabilidade política do período.

Em novembro, porém, aportava no Brasil o paquete com a notícia da adesão de Lisboa à Revolução do Porto em 15 de setembro, sendo a regência destituída e, em seu lugar, instauradas uma Junta Provisional do Governo Supremo do Reino e uma Junta Provisional Preparatória das Cortes. O governo interino, aclamado pelo povo e pelas tropas reunidas no Rossio, tratou de convocar, por meio de um manifesto redigido em 30 de outubro de 1820, Cortes Gerais, Extraordinárias e Constituintes da Nação Portuguesa, esclarecendo, nessa convocação, que se tratavam de Cortes modernas, deliberativas:

Portugueses! Não foi para ressuscitar as antiquadas formas do feudalismo e um vão simulacro de Cortes que nos dias 24 de Agosto e 15 de Setembro, eternamente memoráveis e gloriosos, tomastes a postura terrível de um Povo, que, resgatando-se por sua própria virtude dos ferros, hipoteca suas vidas para segurar sua liberdade (...) Embora a surda voz de um ou outro que só tem abusos por patrimônio reclame frustrantemente o estilo das Cortes antigas, para ele de tão saudosa memória, o clamor geral,

\footnotetext{
${ }^{29}$ A expressão foi usada por NEVES, Lúcia M. Bastos Pereira das. op. cit., p. 241 e SILVA, M. Beatriz Nizza da. A repercussão da revolução de 1820 no Brasil: eventos e ideologias. In: Revista de História das Ideias, v. 2 (1978-1979). Coimbra, p. 7.

${ }^{30}$ NEVES, Lúcia M. Bastos Pereira das. op. cit., p. 241.

${ }^{31}$ Carta de Vilanova Portugal a d. João VI, 28 de outubro de 1820 apud Documentos para a História da Independência, v. 1 (Lisboa - Rio de Janeiro). Rio de Janeiro: Oficinas Gráficas da Biblioteca Nacional, 1923, p. 174.

${ }^{32}$ NEVES, Lúcia M. Bastos Pereira das. “O governo de D. João...”. op. cit., p. 217.

${ }^{33}$ NEVES, Lúcia M. Bastos Pereira das. op. cit., p. 245.
} 
de mãos dadas com o bem comum decreta, sanciona e publica outras Leis. ${ }^{34}$

Essa nova lei, prometida pelos liberais, "não se liga à vontade do Soberano", posto que "um povo, que vai organizar-se, confirma, derroga e altera como lhe parece", como a experiência das demais "Nações constituídas" demonstrava. Com Portugal não seria diferente, e por isso afirmavam: “ Portugueses! (...) Marchareis ao nível do ilustre século, em que tendes a ventura de vos constituirdes". Para tanto, convocavam eleições para as Cortes Gerais, tendo como base as instruções contidas na Constituição espanhola de 1812, aplicáveis a Portugal continental e "às ilhas adjacentes, ao Brasil e aos Domínios Ultramarinos", para que todos os irmãos da grande família portuguesa se reunissem em um único Congresso:

Limita-se a rogar a seus Irmãos Ultramarinos, em nome da Pátria, de tão íntimas e sagradas relações que nos ligam na mesma família; em nome de hábitos que a uns e a outros nos são tão caros; em nome finalmente dos mútuos e recíprocos interesses que nos prendem, não tardem em vir cooperar conosco, em um mesmo Congresso, na regeneração imortal do Império Lusitano. $^{35}$

Algumas províncias brasileiras não hesitaram em responder ao chamado dos liberais. Em janeiro de 1821, o Grão-Pará enviava um ofício à Junta Provisional do Governo Supremo do Reino aderindo à regeneração portuguesa:

Chamados pelo voto livre e espontâneo dos habitantes dessa cidade ao governo provisional da capitania, temos a honra de participar às Vossas Excelências que no dia $1^{\circ}$ de janeiro do corrente, o clero, o povo, as tropas e todas as autoridades constituídas desta capital aclamaram e solenemente juraram obediência a el rei, o Senhor d. João VI, e à augusta Casa de Bragança, às Cortes nacionais e à Constituição, que por elas for estabelecida, mantida a religião católica. ${ }^{36}$

Significativa, na proclamação do Grão-Pará, é a referência a símbolos típicos do Antigo Regime. No intuito de dar legitimidade ao manifesto, recorria-se à aclamação das três ordens típicas de sociedades do antigo sistema, quais sejam, o clero, o povo e a tropa - responsáveis, respectivamente, pela salvação, pelo sustento e pela proteção de todos.

\footnotetext{
34 Proclamação Constitucionalista (30 de dezembro de 1820), disponível em: http://www2.senado.leg.br/bdsf/item/id/242806. Acesso: 26/11/2015.

35 Proclamação Constitucionalista... s/ página.

${ }^{36}$ Apud NEVES, Lúcia Bastos Pereira das. op. cit., p. 244.
} 
Além do mais, aderia-se à Constituição a ser elaborada pelas Cortes portuguesas com a única condição de que a religião católica fosse respeitada e mantida. Infere-se, portanto, mais uma vez, que a introdução de elementos modernos tais como Cortes e Constituição coexistia com a permanência de tradições bem assentadas na sociedade luso-brasileira, nomeadamente o catolicismo e a obediência ao monarca, agora el rei constitucional, aclamado por clero, povo e tropas.

Em 10 de fevereiro era a vez da Bahia manifestar apoio aos portugueses. Na jurada obediência ao rei, a adesão das províncias do Norte e Nordeste evidencia que estas sentiam-se mais ligadas a Lisboa do que ao Rio de Janeiro, que desde 1808 pesava a mão nos impostos cobrados das demais províncias e centralizava todo o poder, configurando o processo que Maria Odila Dias chamou de "interiorização da metrópole":

Como metrópole interiorizada, a Corte do Rio de Janeiro lançou os fundamentos do novo Império português chamando a si o controle e a exploração das outras "colônias" do continente, como o Nordeste. Não obstante a elevação a Reino Unido, o surto de reformas que marca o período joanino visa à reorganização da metrópole na colônia e equivale, de resto, no que diz respeito às demais capitanias, apenas a um recrudescimento dos processos de colonização portuguesa do século anterior. ${ }^{37}$

Ainda segundo esta historiadora, tão ou mais importante do que as reverberações da Revolução do Porto na emancipação política do Brasil seria o processo interno ocorrido na colônia desde a vinda da Corte para o Rio de Janeiro. A interiorização da metrópole foi levada a cabo como "única solução aceitável para as classes dominantes em meio à insegurança que lhes inspiravam as contradições da sociedade colonial" 38 , nomeadamente o “sentimento de insegurança social e o 'haitianismo', ou seja, o pavor de uma insurreição de escravos ou mestiços como a que se dera no Haiti em 1794"39. O enraizamento da metrópole tendo por base o Rio de Janeiro indicava inclusive que a volta da Família Real para Portugal não se daria tão cedo, como as cartas de Luís dos Santos Marrocos deixam entrever:

Não é porque crescem aqui as obras de melhor acomodação futura, mas há cousas particulares e não sei se expressões de autoridade, que fazem recear uma mui prolongada permanência

\footnotetext{
37 DIAS, Maria Odila L. da Silva. “A interiorização da metrópole”. In: metrópole e outros estudos. $2^{\mathrm{a}}$ ed. São Paulo: Alameda, 2005, p. 22.

38 Ibidem, p. 19.

${ }^{39}$ Ibidem, p. 23. A interiorização da
} 
nesse clima. Por todas as repartições eclesiásticas, civis e militares há estas aparências. ${ }^{40}$

Entre as mudanças na nova Corte, citam-se a reforma do arsenal da Marinha, a construção de um palácio no sítio do Andaraí para d. Carlota residir, a expansão do palácio de São Cristóvão para a Família Real passar o verão, a construção do palácio de Santa Cruz para as jornadas de fevereiro, julho e novembro, além do palácio no sítio da Ponte do Caju que consumiria 77 milhões, de uma cadeia nova e de um picadeiro de 50 milhões ${ }^{41}$. Tais reformas e construções, como vimos, foram levadas a cabo graças ao aumento de impostos sobre as demais províncias e apontam para um projeto de permanência da Família Real no país. Não obstante, as notícias das adesões das províncias do Norte e Nordeste à regeneração portuguesa chocaram a Corte; o ministro Silvestre Ferreira lamentaria em uma de suas cartas: "Decidiu-se enfim a sorte do Brasil; quebrouse o nexo que unia suas províncias em comum, e com a dissolução do Brasil se consuma a dissolução da monarquia" ${ }^{42}$.

Aos 26 de janeiro, no Convento das Necessidades, em Lisboa, as Cortes Gerais reuniam-se pela primeira vez, sem, contudo, contar com alguma deputação do ultramar. Apesar da Proclamação Constitucionalista prever eleições às Cortes aplicáveis aos domínios ultramarinos de Portugal, a inércia da Corte frente aos acontecimentos dos meses finais de 1820 contribuiu para que a Assembleia se reunisse contando apenas com deputados portugueses. O jornalista Hipólito José da Costa, escrevendo em Londres, criticaria em seu Correio Braziliense a postura do governo joanino:

Cansados estamos de repetir que os Ministros d'El Rei devem prevenir as revoluções, adotando reformas convenientes ao tempo em que vivemos (...) e se a Corte do Rio de Janeiro continua no mesmo sistema, muito teremos de lamentar a chegada dos males, que nunca temos declarado, mas que nos parece termos suficientemente indicado, para quem está em termos de nos entender. ${ }^{43}$

O jornalista via com maus olhos os efeitos da revolução vintista no Brasil. Descrevia a movimentação constitucionalista ocorrida em $1^{\circ}$ de janeiro no Pará temendo

\footnotetext{
${ }^{40}$ Carta de Luís dos Santos Marrocos a sua família em Lisboa (1811-1821) apud DIAS, Maria Odila L. da Silva. op. cit., p. 20.

41 Ibidem, p. 20-21.

${ }^{42}$ Apud NEVES, Lúcia M. Bastos Pereira das. op. cit., p. 245.

${ }^{43}$ Correio Braziliense, vol. 26, p. 339-345, março de 1821 apud LIMA SOBRINHO, Barbosa. Antologia do Correio Braziliense. Rio de Janeiro: Cátedra; Brasília: Instituto Nacional do Livro, 1977, p. 285.
} 
que se espalhasse pelas demais províncias brasileiras. Clamava ao governo que tomasse as rédeas da situação a fim de "poder dar uma direção" menos perniciosa para o Brasil e para a monarquia e impedir a "dilaceração do Estado" e "uma convulsão geral":

Pode alguém duvidar que a mesma cena se represente em outras capitais do Brasil? Pode haver dúvida que o único partido da Corte é entrar ela mesma na revolução, para lhe poder dar uma direção, que seja a menos perniciosa possível no Brasil? (...) Não pode haver a menor dúvida de que se generalizem em toda a Monarquia os princípios constitucionais; e, contudo, vendo assim cair aos pedaços a sua autoridade ainda não aparece a menor providência no Gabinete para impedir a dilaceração do Estado obstando a uma convulsão geral. ${ }^{44}$

Quanto às Cortes, denunciava a direção "mui errada" que, no seu modo de ver, estavam tomando. Hipólito da Costa criticava o regulamento ${ }^{45}$ para as eleições dos deputados - "copiado da Constituição Espanhola" -, pois excluíam-se "todos os artigos que diziam respeito aos domínios ultramarinos”. Questionava, então, o real fundamento da revolução em Portugal: se era para "melhorar o estado da Monarquia, sem dúvida a primeira consideração devia ser a preservação de toda a mesma Monarquia, e conservação de sua integridade". Ora, como conservar a união de todo o reino sem uma Constituição que o contemplasse em sua totalidade, feita por deputados de todas as partes, e não apenas de uma?, questionava o jornalista, provocando os constitucionalistas. E, nesse mesmo tema, prosseguia:

E se o povo de Portugal assenta, que como povo tem o direito de escolher para si a Constituição que quiser e não a que outrem lhe imponha, seguramente deve convir que não tem direito de ir impor essa Constituição que fizer ao povo do Brasil que nela não teve parte. E que maior causa de divisão e discórdia se pode apresentar a duas porções de uma monarquia, do que tentar uma delas ditar leis constitucionais sem primeiro buscar de ouvir o voto da outra? ${ }^{46}$

Enquanto isso, o Senado da Câmara de Belém tomaria a iniciativa de enviar um representante para "requerer perante as Cortes tudo quanto conviesse ao Pará" ${ }^{47}$. As

\footnotetext{
${ }^{44}$ Correio Braziliense, vol. 26, p. 339-345, março de 1821 apud LIMA SOBRINHO, Barbosa. op. cit., p. 286.

${ }^{45}$ As instruções eleitorais datam de 22 de novembro. Sobre os critérios eleitorais, cf. RODRIGUES, José Honório. Independência... A evolução política, v. 1. op. cit., p. 75.

${ }^{46}$ Correio Braziliense, vol. 26, p. 339-345, março de 1821 apud LIMA SOBRINHO, Barbosa. op. cit., p. 286-287.

${ }^{47}$ CARVALHO, Manuel E. Gomes de. op. cit., p. 14.
} 
comissões de Constituição e de Poderes, porém, indeferiram Felipe Alberto Patroni como deputado, afirmando que a documentação que o instruíra não o nomeava representante da nação. Aceitavam, todavia, que a Assembleia o ouvisse, por exceção, como delegado do governo paraense; Patroni viria a ser, então, o primeiro brasileiro a falar às Cortes em sessão de 5 de abril de 1820. Em seguida, Manuel Fernandes Thomás, um dos líderes do movimento vintista e deputado português, propôs, unanimemente aplaudido, que o Pará passasse a ser considerado província de Portugal, porquanto "se a imensa distância nos separava, o amor fraternal e a comunidade de sentimentos nos uniam"48.

O mesmo Fernandes Thomás, "um liberal cheio de discriminações e preconceitos", nos dizeres de José Honório Rodrigues, viria a ser "o adversário mais ferrenho, sagaz e obstinado dos brasileiros" ${ }^{\prime 4}$ nas Cortes. Como a preocupação primeira dos deputados constituintes foi o retorno do rei a Portugal, Fernandes Thomás escreveria, sob o pseudônimo de "O Impostor Verdadeiro", uma carta-resposta ao jornal Astro de Lusitânia defendendo a volta de d. João VI a Lisboa e desmerecendo o Brasil:

Mas, Senhor Compadre, eu quero agora ser mais generoso e mais liberal que o Astro da Lusitânia; quero ponderar-lhe as razões que devem assistir a S. Majestade para vir estabelecer antes a sua Corte em Lisboa, do que no Rio; (...) Primeiramente o Brasil por vasto, por igual que seja a extensão de toda a Europa, é nada comparado a Portugal, isto é, a sua população, porque eu não meço terreno, meço povos; é um Gigante, em verdade, mas sem braços, sem pernas; não falando no seu clima ardente, e pouco sadio, o Brasil está hoje reduzido a umas poucas hordas de negrinhos, pescados na costa d'África, cínicos, e só capazes de suportar (e não por muito tempo) os dardejantes raios de uma zona abrasada; seu terreno interior está inculto, e seria preciso que decorressem séculos para cultivar-se. ${ }^{50}$

Com efeito, é sob tal visão que Fernandes Thomás defenderia o retorno da Corte a Portugal, descrito como "o jardim das Hespérides, os Elísios deste pequeno mundo chamado Europa!":

Agora destes princípios há de ser Vmcê. mesmo quem há de tirar a conclusão, que não os áulicos do Rio; ora, diga, diga, qual dos dois Reinos está convidando com mais meiguice a S. Majestade para vir estabelecer ele sua Corte: o Brasil ou Portugal? A terra

\footnotetext{
48 Ibidem, p. 15.

${ }^{49}$ RODRIGUES, José Honório. Independência... A evolução política, v. 1. op. cit., p. 77.

${ }^{50}$ Ibidem, p. 78. Para a íntegra da Carta do compadre de Lisboa em resposta a outra do compadre de Belém ou juízo crítico sobre a opinião pública, dirigida pelo Astro de Lusitania cf. CARVALHO, José Murilo de; NEVES, Lúcia Maria B. Pereira das; BASILE, Marcelo (orgs.). Guerra literária: panfletos da Independência (1820-1823), v. 1 (Cartas). Belo Horizonte: UFMG, 2014, p. 160-173.
} 
dos macacos, dos pretos e das serpentes, ou o país de gente branca, de povos civilizados e amantes de seu Soberano? Aquele despovoado e inculto, ou este povoado, ridente e delicioso? (...) Puxe, Senhor Astro, tenha ânimo, tire, tire logo a conclusão! E se não quer, as Cortes cá tirarão. ${ }^{51}$

Sob a liderança de Fernandes Thomás, os deputados portugueses aprovariam decretos recolonizadores ou, no mínimo, antibrasileiros, na medida em que buscavam reduzir a autonomia do Brasil no Reino Unido. Em primeiro lugar, exigiram o retorno imediato do rei a Lisboa. A questão da sede da monarquia era fundamental, do ponto de vista político e simbólico, e não por acaso a questão foi polemizada e devidamente comentada nas folhas dos periódicos e panfletos da época, dos dois lados do Atlântico. O folheto francês atribuído a Cailhé de Geine ${ }^{52}$, Le Roi et la Famille Royalle de Bragance doivent-ils, dans les circonstances présentes, retourner en Portugal, ou bien rester au Brésil?, por exemplo, escrito nos últimos dias de 1820, sugeria a manutenção da Família Real no Brasil dada a predominância deste no Reino Unido:

\begin{abstract}
Parece-nos que se não pode deixar de chegar a esta solução: Que a família de Bragança não deve deixar o Brasil. (...) 1. Que Portugal, no seu estado atual, não pode absolutamente passar sem o Brasil; entretanto que o Brasil, pelo contrário, não tira a menor vantagem da sua União com Portugal. 2. Que a partida da Família Real para a Europa seria o prelúdio da Independência do Brasil, resultado inevitável de um passo tão impolítico. 3. Que Sua Majestade pode conservar Sua Autoridade Real toda inteira no Brasil, e fundar nele um Império florescente de muito grande peso na balança política do Mundo. ${ }^{53}$
\end{abstract}

\footnotetext{
${ }^{51}$ RODRIGUES, José Honório. Independência... A evolução política, v. 1. op. cit., p. 79.

52 “Coronel François Étienne Raymond Cailhé de Geine. Emigrado francês, domiciliado em Paris, que recebeu autorização para servir em Portugal em 1816. Teria chegado a oficial durante a Revolução Francesa. Veio para o Rio de Janeiro a fim de estabelecer uma casa de jogo. Transformou-se em informante da Intendência Geral de Polícia da Corte do Rio de Janeiro". A Cailhe de Geiné é atribuído o folheto francês, mandado imprimir, segundo José Murilo de Carvalho, Lúcia Neves e Marcello Basile, pelo ministro Vilanova Portugal. Apud CARVALHO, José Murilo; NEVES, Lúcia M. Bastos Pereira das; BASILE, Marcello (orgs.). Às armas cidadãos. Panfletos manuscritos da Independência do Brasil. São Paulo: Companhia das Letras, 2012.

${ }^{53}$ Documentos para a História da Independência... op. cit., p. 201-208. Cf. também CARVALHO, José Murilo de; NEVES, Lúcia M. Bastos Pereira das; BASILE, Marcelo (orgs.). Guerra literária... vol. 2 (Análises), op. cit., p. 38-47. No original: 'Il nous semble qu'on ne peut manquer d'arriver à cette solution: Que la famille de Bragance ne doit pas quitter le Brésil. (...) 1. Que le Portugal, dans son état actuel, ne peut absolutement point se passer du Brésil, tandis que le Brésil ne relève au contraire pas le moindre avantage de son union avec le Portugal. 2. Que le Départ de la famille Royale pour l'Europe serait le prélud de l'Independace du Brésil résultant inévitable d'une démarche aussi impolitique. 3. Que Sa Majesté peut conserver son Autorité Royale toute entière au Brésil et y fonder un Empire florissant d'um très grand poids dans la balance du Monde".
} 
Como resposta a esse folheto, surgia outro escrito na Bahia, em 1821, intitulado Exame crítico-analítico da solução da questão: o Rei e a Família Real de Bragança devem, nas circunstâncias presentes, voltar a Portugal, ou ficar no Brasil?. O autor, por sua vez, mostrava-se favorável ao regresso de d. João VI à Europa, bem como assumia uma postura otimista com relação à Constituição a ser elaborada pelas Cortes - o que se revela bastante significativo da adesão da Bahia ao movimento constitucionalista português. O Exame analítico-crítico atribuía as proposições contidas no folheto francês a um "indigno filho (...) Réu de alta traição contra seu Rei e sua Pátria"; reconhecia a decadência econômica e política portuguesa, mas afirmava que "o Brasil generoso não quer vê-los rotos e famintos: espera-os como Irmãos, com quem está unido". Por fim, solicitava o retorno do rei para o "Berço da Monarquia":

Diga a El Rei Nosso Senhor que volte para o Berço da Monarquia, para a terra que o viu nascer; que vá visitar os veneráveis Túmulos de Seus Augustos Avós, e sobretudo consolar as saudades, e limpar as lágrimas de seus fiéis Vassalos. Que se contemple no meio deles como o Ínclito Afonso Primeiro subscrevendo as determinações da Nação, e jurando a Constituição para a paz de seus Reinos, e consolação de seus amantíssimos filhos. ${ }^{54}$

Após muito hesitar, com a chegada da notícia da adesão baiana ao movimento constitucionalista, a Corte se vê obrigada a tomar uma posição. Em 23 de fevereiro publica-se um decreto, datado de 18, determinando o envio de d. Pedro a Portugal, a fim de "pôr logo em execução medidas e providências" para "restabelecer a tranquilidade geral daquele Reino" e assegurar "as reformas e melhoramentos e as Leis que possam consolidar a Constituição portuguesa". O decreto reconhecia, porém, que a futura Constituição não poderia ser "igualmente adaptável e conveniente em todos os seus artigos e pontos essenciais, à povoação, localidade e mais circunstâncias tão ponderosas como atendíveis deste Reino do Brasil”55. Tratava-se, assim, de seguir a orientação do ministro Vilanova Portugal de manter d. João VI no Brasil e poupar o país do contágio revolucionário, preservando a autoridade real na América.

Na mesma data, publicou-se um segundo decreto que convocava os procuradores das câmaras das cidades e das principais vilas do Brasil a formarem cada uma delas sua

\footnotetext{
${ }^{54}$ Documentos para a História da Independência... op. cit., p. 208-215. Cf. também CARVALHO, José Murilo de; NEVES, Lúcia M. Bastos Pereira das; BASILE, Marcelo (orgs.). Guerra literária... vol. 2 (Análises), op. cit., p. 126-146.

${ }^{55}$ Apud NEVES, Lúcia M. Bastos Pereira das. op. cit., p. 246.
} 
Junta de Cortes, instância que examinaria as leis provenientes dos trabalhos do Soberano Congresso de Lisboa. Tais decretos foram mal recebidos por grande parte dos portugueses residentes no Brasil e por simpatizantes do movimento constitucionalista, já que sugeria que a Constituição deixaria de ser obra da nação para se tornar uma dádiva do soberano, além de contrariar a exigência das Cortes quanto ao retorno do rei a Portugal. Acirraramse os ânimos de tal modo que o próprio monarca reconheceu a necessidade de apaziguar os espíritos: "Agora acaba de falar-me o comandante da Polícia, dizendo-me que o que

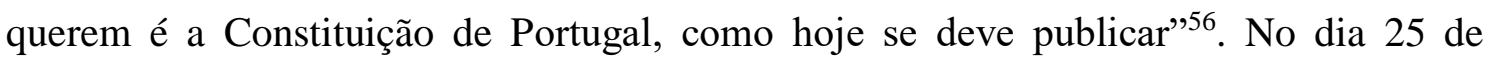
fevereiro, d. João solicitaria ao conde de Palmela que redigisse as bases de uma Constituição a fim de evitar a revolução na Corte. Porém, era tarde demais.

Na madrugada do dia 26 de fevereiro, reuniram-se tropa e povo no Largo do Rossio (atual Praça Tiradentes); era a adesão do Rio de Janeiro ao movimento constitucionalista. Exigiam o juramento do soberano às bases da futura Constituição portuguesa, a demissão de seus ministros e a adoção temporária da Constituição espanhola de 1812, até a elaboração da nova Carta pelas Cortes. Em verdade, o movimento foi liderado pela Divisão Auxiliadora portuguesa, comandada pelo tenentegeneral Jorge de Avilez, Governador das Armas da Corte. Segundo correspondência do ministro Silvestre Ferreira, os militares foram levados a esse "fatal descontentamento" por acreditarem que a demora do governo em aceitar o constitucionalismo português não passava de um meio para "cortar todas as relações com aquele Reino", retirando "às tropas da Divisão portuguesa todas as esperanças de a ele tão cedo e porventura jamais poderem regressar" ${ }^{, 57}$.

Representando o rei, d. Pedro compareceu ao Rossio para ouvir as reivindicações dos revoltosos, agindo com muita habilidade. Segundo Oliveira Lima, nessa ocasião, d. Pedro fez "em ponto pequeno o que em ponto grande faria com relação à Independência: pôs-se à cabeça do movimento" ${ }^{58}$. Designou, em nome de seu pai, novos ministros e jurou a futura Constituição portuguesa. Evitou, porém, que se adotasse a Constituição espanhola e que se procedesse à formação de uma Junta governativa popular, a exemplo das juntas baiana e paraense. Era o início do protagonismo do jovem príncipe na vida política do Brasil: quando a província de maior importância do Brasil, o Rio de Janeiro, adere ao movimento constitucionalista português, é d. Pedro quem assume a liderança

\footnotetext{
${ }^{56}$ Apud NEVES, Lúcia M. Bastos Pereira das. op. cit., p. 246.

${ }^{57}$ Apud NEVES, Lúcia M. Bastos Pereira das. op. cit., p. 247.

${ }^{58}$ Apud NEVES, Lúcia M. Bastos Pereira da. op. cit., p. 249.
} 
dos acontecimentos, enquanto seu pai permaneceria recluso no palácio de São Cristóvão com seus ministros, oscilando quanto às ações que deveria tomar. Tal comportamento certamente influenciou a identificação da figura do príncipe com a causa liberal e, mais tarde, com a Independência do Brasil.

Segundo Lúcia Neves, o movimento constitucionalista de 26 de fevereiro ganhou as páginas de vários pasquins. As folhas narravam a alegria do público, afirmando ser impossível "explicar os transportes de prazer e satisfação com que todos se abraçavam, dando-se mútuos parabéns e não podendo conter o alvoroço em que nadavam seus corações" "59; descrevia-se o dia 26 como o "dia de salvação e de Regeneração do Reino do Brasil!" ${ }^{60}$. Igualmente em Portugal, a notícia da adesão do Rio de Janeiro ao movimento causou grande júbilo, "iluminando-se voluntariamente a cidade de Lisboa"61.

Os liberais portugueses tiveram um novo motivo para comemorar quando, a 7 de março, d. João assinou decreto anunciando seu tão aguardado regresso à velha metrópole, a fim de ali "cooperar com os deputados procuradores dos povos na gloriosa empresa de restituir à briosa Nação portuguesa aquele grau de esplendor, com que tanto se assinalou nos tempos antigos" ${ }^{\prime 2}$. Em outro decreto do mesmo dia, o rei determinou que se procedessem às eleições dos deputados brasileiros às Cortes portuguesas: "Hei por bem Ordenar que neste Reino do Brasil e Domínios Ultramarinos se proceda desde logo a nomeação dos respectivos Deputados" ${ }^{\prime 63}$, seguindo, mais uma vez, as instruções contidas na Constituição espanhola. Seu regresso, porém, não se daria tão cedo, sendo sempre adiado: d. João ainda hesitava quanto aos rumos políticos do Império luso-brasileiro.

Antes de partir, o rei ainda enfrentou um "incidente na praça do Comércio", que teve lugar entre os dias 21 e 22 de abril, quando da realização das eleições para os eleitores de comarca ${ }^{64}$. As instruções contidas no decreto de 7 de março afirmavam que a reunião

\footnotetext{
${ }^{59}$ Gazeta do Rio de Janeiro, $\mathrm{n}^{\circ}$ 17, 28 de fevereiro de 1821 apud NEVES, Lúcia M. Bastos Pereira das. op. cit., p. 249.

${ }^{60}$ O Conciliador do Reino Unido, $\mathrm{n}^{\circ} 1,1^{\circ}$ de março de 1821 apud NEVES, Lúcia M. Bastos Pereira das. op. cit., p. 249.

${ }^{61}$ NEVES, Lúcia M. Bastos Pereira das. op. cit., p. 250.

${ }^{62}$ Apud NEVES, Lúcia M. Bastos Pereira das. op. cit., p. 251.

${ }^{63}$ Gazeta do Rio de Janeiro, no 22, 17 de março de 1821.

${ }^{64}$ Segundo as instruções, as eleições se davam em quatro graus. Primeiramente, os votantes elegiam os compromissários da freguesia; estes elegiam os eleitores paroquias que, por sua vez, elegiam os eleitores da comarca; estes últimos elegeriam os deputados. Segundo José Murilo de Carvalho, o primeiro e o segundo graus de votantes era amplo, uma vez que a única exigência era ser cidadão (homem livre) residente e domiciliado na respectiva freguesia. Nos graus seguintes, além do domicílio na freguesia, requeria-se ter mais de 25 anos. Neste momento, não existiam critérios censitários, tratando-se quase de um "voto universal masculino". Cf. CARVALHO, José Murilo de. "A involução da participação eleitoral no Brasil: 1821-1930”. In: CARVALHO, José Murilo de; CAMPOS, Adriana Pereira (orgs.). op. cit., p. 40.
} 
dos eleitores deveria se dar no domingo, 22, a tempo da chegada à Corte dos eleitores vindos das diferentes regiões da província. Contudo, como nos conta Cecília de Salles Oliveira, entre os dias 19 e 20 "foram afixados editais, nos principais lugares públicos da cidade" 65 , antecipando a reunião para a tarde do dia 21. Os mentores dessa decisão, como o conde dos Arcos, barão de Santo Amaro e Carneiro de Campos - todos homens ligados ao governo regencial que se formava - pretendiam enfatizar que a partida do Rei era irreversível e conseguir o apoio dos eleitores para a instauração da regência. $\mathrm{O}$ autor de uma Memória sobre os acontecimentos dos dias 21 e 22 de Abril de 1821 na praça do Comércio do Rio de Janeiro, escrito em Maio do mesmo ano por uma testemunha presencial que representa a indignação do liberal radical perante a narrativa publicada na Gazeta relataria que o ouvidor da comarca havia convocado por edital a junta eleitoral a fim de se "reunir extravagantemente" um dia antes do previsto, afirmando que a mudança repentina de data "causou grande surpresa" 66 a todos.

Assim que os eleitores chegaram ao local marcado, foram informados do conteúdo de um decreto, já assinado pelo rei, "que determinava as atribuições de d. Pedro e a relação das pessoas que comporiam o 'governo provisório"”67. Segundo Cecília Oliveira,

apesar de os editais de convocação mencionarem que aos representantes dos "povos da província" caberia apresentar sugestões e pareceres sobre as medidas que a regência poderia tomar, não se cogitava sua interferência na composição do governo. Ou seja, ao mesmo tempo em que solicitava a participação dos eleitores, esta deveria se limitar à aceitação daquilo que já estava decidido. ${ }^{68}$

Nesse sentido, tanto o autor da Memória quanto Silvestre Ferreira em sua correspondência classificariam a Assembleia como "plenamente consultiva"69, e não deliberativa, dando tonalidade a uma monarquia ainda nos moldes do Antigo Regime. Quando a reunião perdeu o controle, clamando por soberania popular, a repressão foi violenta. No dia seguinte, todavia, aos 23 de abril, a "versão oficial" dos fatos negaria o caráter consultivo da Assembleia, uma vez que a Proclamação do Rei aos habitantes do Rio de Janeiro acentuaria apenas o intuito eletivo da reunião: "iludiram-vos com direitos

\footnotetext{
${ }^{65}$ OLIVEIRA, Cecília H. de Salles. op. cit., p. 138.

${ }^{66}$ Apud SILVA, M. Beatriz Nizza da. A repercussão da revolução... op. cit.., p. 41.

${ }^{67}$ OLIVEIRA, Cecília H. de Salles. op. cit., p. 139.

${ }^{68}$ Idem.

${ }^{69}$ NEVES, Lúcia M. Bastos Pereira das. op. cit., p. 253.
} 
que não vos competem. Os eleitores das paróquias só os tinham para a eleição dos de comarca e o povo nenhum mais tinha depois de eleitos os compromissários"70.

Cecília de Salles Oliveira demonstra a astúcia de homens como Gonçalves Ledo e Clemente Pereira - eleitores de comarca, proprietários rurais fluminense -, que tramaram para que a reunião da junta eleitoral se transformasse em uma espécie de Assembleia Legislativa. Contando com o apoio do ouvidor da comarca, Joaquim José de Queiroz, transferiram o local da reunião do interior de uma Igreja para o amplo e luxuoso edifício da praça do Comércio. A intenção era reunir um grande número de pessoas para se utilizar da pressão do "povo"71 não só "para indicar os eleitores de comarca e os deputados junto às Cortes, mas para 'eleger' um governo que atendesse a suas pretensões" ${ }^{\text {72 }}$. O grupo de Ledo incitava os populares a exigirem a adoção imediata da Constituição espanhola até que se aprontasse a Carta portuguesa, bem como a nomeação de uma Junta de governo, indicada pela Assembleia, para acompanhar o governo do príncipe regente:

\begin{abstract}
Ansioso por exercer o poder, o grupo de Ledo não pretendia aguardar por decisões das Cortes em Lisboa (...) já que não estava disposto a aceitar que, pela mediação da regência de d. Pedro, seus principais adversários continuassem na direção dos negócios públicos. A Constituição espanhola continha dispositivos que permitiriam a esses liberais concretizar pelo menos algumas das propostas que defendiam. O primeiro deles constituía um dos fundamentos sobre os quais alicerçava-se a prática política que exerciam: o poder soberano pertencia aos "cidadãos". A esses e a seus representantes cabia o direito de elaborar as leis e de determinar as pessoas e a forma com que deveriam governar. ${ }^{73}$
\end{abstract}

Na luta política travada, o grupo de Ledo pretendia controlar a administração, manipulando a seu favor as reivindicações dos mais variados setores da sociedade, como os soldados, os funcionários públicos, os artesãos, os comerciantes, os pequenos proprietários e os homens pobres. Nessa luta "contra dirigentes da monarquia e os 'grandes' da província, a arma seria a canalização das pressões ‘populares",774. Entretanto,

\footnotetext{
${ }^{70}$ Apud NEVES, Lúcia M. Bastos Pereira das. op. cit., p. 253.

${ }^{71}$ Sobre a noção de "povo" na cultura política da Independência, cf. NEVES, Lúcia M. Bastos Pereira das. op. cit., especialmente capítulo 3. "Povo" era caracterizado por setores da sociedade que não eram nem as tropas, nem as elites ilustradas. Acabavam instruídos ou pela leitura dos periódicos e folhetos (quando alfabetizados) ou pelo "boca-a-boca", pela troca de informações que aconteciam nos diferentes espaços de sociabilidades do Oitocentos, como as sociedades secretas, as praças, os cafés, as igrejas e etc.

${ }^{72}$ OLIVEIRA, Cecília H. de Salles. op. cit., p. 141.

${ }^{73}$ Idem.

${ }^{74}$ Ibidem, p. 142.
} 
no decorrer da Assembleia, nas palavras do autor da Memória, "todo o mundo julgou que devia ter parte nesta eleição; a confiança apoderou-se dos cidadãos"75; Ledo e seu grupo não enfrentaram apenas os seus adversários políticos, mas as exigências da multidão congregada na praça. O "povo" revelou que "nem sempre estaria disposto a partilhar dos projetos defendidos por proprietários e em vez de se submeter passivamente às decisões, passou a intervir na discussão travada entre os eleitores"76.

"Advogados, meirinhos, boticários e alfaiates" questionavam a organização do governo provisório indicado pelo grupo de Ledo. Ao mesmo tempo, comerciantes e artesãos defendiam o fechamento dos portos do Rio de Janeiro, requerendo que nenhuma embarcação deixasse o porto da cidade "antes de ser vistoriada pelos oficiais das fortalezas da barra, para evitar a saída de moedas e remessa de valores para o exterior"77. A reunião da junta eleitoral prolongara-se madrugada adentro, aflorando exigências desencontradas em meio às idas e vindas das comissões encarregadas de apresentar ao rei as decisões tomadas na Assembleia. O caráter altamente democrático do incidente da praça do Comércio alarmou as autoridades reunidas no Palácio de São Cristóvão, entre elas o conde dos Arcos e d. Pedro, gerando uma repressão foi violenta. Segundo Silvestre Ferreira, o êxito da liquidação do movimento cabia "principalmente a d. Pedro", já que a ordem do ataque partira do próprio príncipe, “que, no fundo, já dava mostras de não ser tão adepto das ideias de um liberalismo mais democrático"78.

Quatro dias depois, aos 26 de abril, d. João VI enfim partiria com sua comitiva para Portugal, deixando o governo nas mãos de seu filho de vinte e dois anos. "Pedro, se o Brasil se separar, antes seja para ti, que me hás de respeitar, que para algum desses aventureiros"79, teria dito d. João dois dias antes de partir. O artista francês J. Baptiste Debret assim descreveu a partida do monarca:

O Rei, tomado de terror e pânico, esqueceu a felicidade de reinar sossegadamente na América e, dominando a repugnância supersticiosa que o dominava, de uma segunda travessia, consentiu finalmente em embarcar. A nobreza deveria acompanhá-lo e assim o encorajava ainda, fazendo-o crer que sua presença em Lisboa iria trazer calma e obediência (...) o tímido monarca embarcou em S. Cristóvão às seis horas da manhã, no próprio dia da partida, acompanhado de d. Miguel e da jovem

\footnotetext{
${ }^{75}$ Apud SILVA, M. Beatriz Nizza da. A repercussão da revolução... op. cit., p. 41.

${ }^{76}$ OLIVEIRA, Cecília H. de Salles. op. cit., p. 143.

${ }^{77}$ Idem.

${ }^{78}$ NEVES, Lúcia M. Bastos Pereira das. op. cit., p. 254.

${ }^{79}$ Carta de 19 de junho de 1821 apud RODRIGUES, José Honório. Independência... A evolução política, v. 1, op. cit., p. 169 ;
} 
viúva (...) O príncipe regente e sua família encontravam-se a bordo para receber o Rei e apresentar as despedidas. O príncipe só deixou seu pai quando o navio atingiu a saída da barra. A flotilha compunha-se de cinco embarcações portuguesas. Às oito horas e três quartos do dia 26 de abril de 1821 as salvas de artilharias dos fortes da baía anunciaram aos habitantes do Rio de Janeiro a partida definitiva do soberano fundador do Reino do Brasil. $^{80}$

O governo regencial encontrava-se nas mãos do jovem príncipe, que já vinha assumindo o protagonismo político desde a adesão do Rio de Janeiro ao movimento constitucionalista, aos 26 de fevereiro. Tratando pessoalmente com as tropas do Largo do Rossio enquanto seu pai aguardava notícias no palácio de São Cristóvão, d. Pedro negociaria um novo ministério com os revoltosos e juraria a Constituição portuguesa a ser elaborada, evitando que se adotasse a Constituição de Cádiz e se formasse uma junta provisória da cidade, a exemplo do que ocorrera na Bahia e Grão-Pará. Demonstraria, portanto, forte espírito de liderança que o levaria a ser um grande protagonista de nossa Independência. Já nas suas primeiras ações políticas evidencia-se o seu caráter liberal, ainda que avesso a um radicalismo e às aspirações democráticas, como o fato de ter ordenado a violenta repressão e dissolução da reunião de eleitores da praça do Comércio ratifica.

\section{A tumultuada regência de d. Pedro}

D. João fora impelido pelo medo, e pelo medo, à pátria regressava. Sua regência em Portugal resultara na ocupação do país; sua regência no Brasil, na perda da colônia. (...) D. Pedro não era assim. Era um conquistador amoroso, um sedutor de povos, gozava de popularidade e, desde 24 a 26 de fevereiro de 1821, ainda com o pai como rei, era ele, de fato, a autoridade, e começava a encarnar, apesar das hesitações, a Revolução Brasileira. $^{81}$

Assim o historiador José Honório Rodrigues descreveria d. Pedro, o regente que assumia o governo constitucional do Brasil com amplos poderes, concedidos pelo decreto régio de 22 de abril. $\mathrm{O}$ mesmo decreto nomeava um Conselho de Estado que o ajudaria a governar, formado por dois ministros - Marcos de Noronha e Brito, conde dos Arcos

\footnotetext{
${ }^{80}$ Apud FALCÓN, Francisco C.;MATTOS, Ilmar R. de. "O Processo de Independência no Rio de Janeiro". In: MOTA, Carlos Guilherme (org.). op. cit., p. 292-293.

${ }^{81}$ RODRIGUES, José Honório. Independência... A evolução política, v. 1. op. cit., p. 170.
} 
(Reino e Estrangeiros) e Diogo de Menezes, conde de Lousã (Fazenda) - e por dois secretários - marechal Carlos Frederico de Caula (Guerra) e major general Manuel Antonio Farinha (Marinha) ${ }^{82}$. Estava formado o governo da regência, uma autoridade central emanada do Rio de Janeiro que deveria congregar todas as demais províncias.

Entre suas novas atribuições, além dos poderes normais de administração da Justiça, Fazenda e Economia, cabia ao regente comutar e perdoar penas de morte, prover lugares vagos de letras e demais dignidades eclesiásticas (à exceção dos bispados), fazer guerra ofensiva e defensiva contra qualquer inimigo, bem como proclamar trégua, e ainda conferir como graças e honoríficos os hábitos das três ordens militares (São Tiago da Espada, de Cristo e de São Bento de Avis). Previu-se a hipótese de sua morte, sucedendolhe a princesa Leopoldina, "medida sumamente importante, pois a ela coube presidir o Conselho de Estado na reunião decisiva de 2 de setembro, quando d. Pedro estava em São Paulo e medidas urgentes eram necessárias", resultando na Independência ${ }^{83}$.

No dia seguinte à partida do pai, d. Pedro lançou uma proclamação aos brasileiros, redigida, ao que tudo indica, pelo conde dos Arcos, na qual resumia o programa de reformas que pretendia executar. Cuidaria da "felicidade do Brasil até que de Portugal chegasse a Constituição", promovendo a educação, a agricultura, o comércio e as demais reformas que garantissem a prosperidade pública ${ }^{84}$. A prioridade do governo, inicialmente, seria a de estabilizar a economia; o biógrafo de d. Pedro, Octávio Tarquínio de Souza, descreveria o "caos financeiro que lhe herdara o pai", com o Banco do Brasil próximo da bancarrota e o numerário partindo juntamente com a Família Real para Lisboa $^{85}$.

Em seus primeiros meses de governo, d. Pedro baixou decretos que confirmavam o liberalismo econômico que professava, como o de 21 de maio, que proibia a desapropriação de bens particulares tendo em vista o respeito ao "sagrado direito de propriedade". Tal decreto foi completado pelo de 23 do mesmo mês que versava sobre a liberdade individual, ordenando que nenhuma pessoa livre (os escravos estavam naturalmente excluídos) pudesse jamais ser presa no Brasil sem ordem por escrito do juiz ou magistrado; que nenhum juiz expedisse ordem de prisão sem preceder culpa formada; que o processo se fizesse dentro de 48 horas confrontando o réu com as testemunhas,

\footnotetext{
${ }^{82}$ NEVES, Lúcia M. Bastos Pereira das. op. cit., p. 256.

${ }^{83}$ RODRIGUES, José Honório. Independência... A evolução política, v. 1. op. cit., p. 170.

${ }^{84}$ SOUZA, Octávio Tarquínio de. História dos Fundadores do Império do Brasil, vol. 2 (A vida de d. Pedro I), tomo I, $3^{\text {a }}$ ed. Rio de Janeiro: José Olympio, 1957, p. 270.

${ }^{85}$ Ibidem, p. 272.
} 
facilitados todos os meios de defesa; e que em hipótese nenhuma "alguém fosse 'lançado em segredo ou masmorra estreita, escura e infecta', abolido para sempre 'o uso de correntes, algemas, grilhões e outros ferros" " usados para martirizar homens ainda não julgados ${ }^{86}$.

Tais decretos que amparavam a propriedade e a liberdade individual de todos os homens livres causaram uma impressão favorável do novo governo. Porém, o fato de não haver um só brasileiro no Conselho de Estado colocava sob suspeita os verdadeiros interesses da nova administração, gerando desconfianças. A separação política de Portugal e do Brasil ia lentamente se desenhando, na medida em que se acirravam os ânimos entre os portugueses - que estavam no poder e contavam com o auxílio militar da Divisão Auxiliadora - e os brasileiros - membros da elite local que pleiteavam posições de poder junto ao príncipe.

O conde dos Arcos, figura central neste momento - tido pelos contemporâneos como um "primeiro ministro ou quase ministro único" 87 -, era considerado pelos portugueses como "partidário decidido do Brasil", e pelos brasileiros como "um reinol, com todos os seus preconceitos" $" 88$. O clima de desconfianças dos dois lados provocou um novo levantamento militar dos soldados portugueses estabelecidos no Rio de Janeiro, a "Bernarda" de 5 de junho. O novo levante das tropas levou d. Pedro a jurar as bases da Constituição portuguesa, chegadas de Lisboa em fins de maio, e a demitir seus ministros, que haviam sido nomeados por seu pai. José Honório Rodrigues conta que o príncipe, com “sua inabalável coragem", enfrentou o general Avilez, recusando-se a jurar as bases até "saber se tal era a vontade do povo" 89 , mandando convocar os eleitores e o Senado da Câmara para tal fim. Em carta ao pai, d. Pedro narraria os acontecimentos de 5 de junho:

Já suspeitando que a tropa auxiliadora me queria fazer um requerimento para eu consentir que se ajuntassem para jurarem as bases (...) às cinco horas da madrugada montei no meu cavalo e fui ao batalhão 3 para ver se eles me pediam alguma coisa sobre isto; (...) Chegando, vieram todos os oficiais com o general à testa e eu lhes perguntei: "Quem é que fala aqui?" (...) Disse o general: "Eu, pela tropa". "Que querem?". Disse ele: "Jurarmos a bases constitucionais portuguesas". Respondi (...): "Eu não juro sem saber a vontade do povo que estou governando, porque a tropa é

\footnotetext{
${ }^{86}$ Ibidem, p. 271.

87 A observação sobre o conde dos Arcos foi feita pelo diplomata inglês em visita ao Brasil Edward Thornton apud SOUZA, Octávio Tarquínio de. História dos fundadores do Império... vol. 2 (A vida de d. Pedro I), op. cit., p. 269.

${ }^{88}$ NEVES, Lúcia M. Bastos Pereira das. op. cit., p. 256.

${ }^{89}$ RODRIGUES, José Honório. Independência: revolução e contra-revolução. As forças armadas, v. 3. Rio de Janeiro: Biblioteca do Exército, 2002, p. 183.
} 
uma parte da nação, por isso não valia de nada querer sem eu saber a vontade da nação para então deliberar" 90

Para Octávio Tarquínio de Souza, o fato de d. Pedro ir sozinho enfrentar a tropa em armas era bastante característico de seu feitio psicológico: "não se deteria na quinta da Boa Vista, a esperar, indeciso, o que pudesse suceder, como faria d. João VI"91 . Em sessão continuada nos dias 8, 9 e 14 de junho, o Senado da Câmara aprovou as bases e d. Pedro, depois de "saber que o voto do povo era aquele, não por medo, mas por convicção própria" ${ }^{92}$ procedeu também ao juramento, expedindo decreto no dia seguinte para que todas as províncias do Brasil seguissem seu exemplo. A segunda reivindicação das tropas também foi acatada pelo regente, que demitiu o conde dos Arcos, substituindo-o pelo desembargador do Paço, Pedro Álvares Diniz. Antes de deixar o batalhão, no Largo do Rossio, d. Pedro disse-lhes, por fim: "arranjem-se desta vez como bem lhe parecer, porque eu, terceira vez, não venho cá, e Deus sabe onde eu irei"93.

Desde 16 de abril, as Cortes autorizavam a formação de governos provisórios e juntas governativas submetidas à Lisboa, como as que já haviam sido formadas nas províncias da Bahia e do Pará. Após a "Bernarda" de 5 de junho, d. Pedro baixaria decreto autorizando a formação dessas juntas, atendendo às "razões que Me foram ponderadas pelo Povo e Tropa desta cidade" 94 . Em verdade, antes mesmo do decreto régio, várias foram as províncias que criaram juntas governativas, minando a autoridade central do Rio de Janeiro, considerando-se que muitas se submetiam antes às Cortes do que ao príncipe. O governo enfrentou problemas com "o espírito de autonomia e liberdade" 95 das juntas do Maranhão, Piauí, Ceará, Pernambuco e Minas Gerais, para citar alguns exemplos. A Junta Provisional da Bahia chegou inclusive a formalizar seu desligamento do Rio de Janeiro, acusando o "abusivo" decreto de 22 de abril, que vinculava as províncias do Brasil ao Rio, de um

desejo mal coberto de semear a cizânia e gerar divisões entre portugueses dos dois hemisférios. Acostumar os portugueses do Brasil a nada terem em comum com os portugueses da Europa

\footnotetext{
${ }^{90}$ Carta de d. Pedro a d. João, 8 de junho de 1821 apud LIMA JÚNIOR, Augusto de. Cartas de d. Pedro a d. João VI relativas à Independência do Brasil. Rio de Janeiro: Jornal do Comércio, 1941, p. 17-18.

${ }^{91}$ SOUZA, Octávio Tarquínio de. História dos fundadores do Império... vol. 2 (A vida de d. Pedro I), op. cit., p. 281.

92 Carta de d. Pedro a d. João, 8 de junho de 1821 apud LIMA JÚNIOR, Augusto de. op. cit., p. 19.

${ }^{93}$ Carta de d. Pedro a d. João, 8 de junho de 1821 apud LIMA JÚNIOR, Augusto de. op. cit., p. 18.

94 Apud SOUZA, Octávio Tarquínio de. História dos fundadores do Império... vol. 2 (A vida de d. Pedro I), op. cit., p. 284.

${ }^{95}$ NEVES, Lúcia M. Bastos Pereira das. op. cit., p. 269
} 
era calçar a estrada para uma projetada e fácil separação das duas partes do Império. ${ }^{96}$

Assim sendo, de um modo geral, durante o ano de 1821, as províncias brasileiras tenderam a uma

autonomia interna, ora ligando-se diretamente às Cortes de Lisboa, como o Pará, o Maranhão, o Piauí e a Bahia; ora adotando uma postura marginal no curso dos fatos, devido à distância ou isolamento, a exemplo de Goiás, Mato Grosso e Rio Grande do Sul. ${ }^{97}$

Enquanto isso, no Rio de Janeiro, d. Pedro escrevia ao pai desesperançado - em nada parecido com o perfil corajoso traçado por Octávio Tarquínio de Souza e por José Honório Rodrigues ${ }^{98}$-, descrevendo a delicada situação do Brasil e pedindo urgentemente que as Cortes, "de comum acordo com Vossa Majestade, deem as providências tão necessárias a este reino, de que eu fiquei regente, e hoje sou capitãogeneral, porque governo só a província" 99 . Dois meses depois, em 21 de setembro, d. Pedro rogaria a seu pai, "por tudo que há de mais sagrado", para que o dispensasse "deste emprego, que seguramente me matará", devido às "tristes, lamentáveis cenas e circunstâncias em que me acho"100. Alguns dias depois, as Cortes acabariam por atender a vontade do príncipe, determinando a sua volta à Portugal. Porém, tal notícia só chegaria ao Rio de Janeiro em inícios de dezembro, quando a situação já se mostrava bastante diferente.

\section{0 fim da cooperação entre "irmãos": os decretos das Cortes}

Foi ainda no longo ano de 1821 que se deram as eleições dos deputados brasileiros às Cortes de Lisboa. O processo eleitoral era um indicativo da "nova ordem das coisas"

\footnotetext{
${ }^{96}$ Ibidem, p. 268-269.

97 Ibidem, p. 271-272.

98 Vale ressaltar que José Honório Rodrigues, em seu livro Independência: revolução e contra-revolução (v. 1, "A evolução política"), de 1975, traça um perfil bastante corajoso e enérgico de d. Pedro, sobretudo quando comparado a seu pai. Já em sua obra A Assembleia Constituinte de 1823, escrita em 1974, o historiador destacaria o absolutismo de d. Pedro que resultou na dissolução da Assembleia, freando a revolução da Independência brasileira. Segundo Rodrigues, "a Assembleia Geral Legislativa e Constituinte soube enfrentar com tranquilidade, com destemor, com dignidade, a indignidade de d. Pedro I e de seus janízaros, na maioria oficiais portugueses". RODRIGUES, José Honório. A Assembleia Constituinte de 1823. Petrópolis: Editora Vozes, 1974, p. 221-222.

${ }^{99}$ Carta de d. Pedro a d. João, 17 de julho de 1821 apud LIMA JÚNIOR, Augusto de. op. cit., p. 22.

${ }^{100}$ Carta de d. Pedro a d. João, 21 de setembro de 1821 apud LIMA JÚNIOR, Augusto de. op. cit., p. 28.
} 
estabelecida pela monarquia constitucional, e era bastante significativo, na medida em que depositava "nas mãos do povo a responsabilidade pela escolha dos membros do poder legislativo". Tal processo absorvia "todo o simbolismo dos novos valores do homem liberal" ${ }^{101}$. No Brasil, os critérios para as eleições foram regulados pelo decreto de 7 de março. Neste momento, as Cortes já estavam em pleno funcionamento. Aos 13 de julho, após a chegada da comitiva de d. João a Lisboa com as notícias da adesão do Rio de Janeiro ao movimento constitucionalista, os portugueses trataram de elaborar uma proclamação aos brasileiros convocando-os a escolherem seus representantes para o Soberano Congresso. Assim, declaravam ser possível "completar o quadro da representação nacional para auxiliar as Cortes em suas laboriosas tarefas, e tomar as deliberações a parte que devem ter"102.

Iniciaram-se, portanto, as eleições em diversas províncias brasileiras, sem que, contudo, fosse seguido um calendário eleitoral comum. Se a província do Rio de Janeiro foi a primeira a realizar as eleições, foram os deputados pernambucanos a precederem todos os demais brasileiros no Soberano Congresso de Lisboa, tomando assento aos 29 de agosto de 1821. O historiador Fernando Tomaz escreveria que "desde a chegada da primeira deputação brasileira às Cortes, portugueses e brasileiros falaram, na verdade, linguagens diferentes sob a aparência de intenções convergentes" ${ }^{" 103}$. Antes mesmo que os deputados pernambucanos tomassem assento, as Cortes haviam decidido sobre a remessa de tropas portuguesas para o Brasil, destinadas a substituírem as que já há muito tempo serviam no Rio de Janeiro:

\footnotetext{
O aparente objetivo dessa expedição militar era reforçar o poder de d. Pedro contra as correntes mais democráticas, mas, na realidade, na visão dos líderes vintistas, afastar a Divisão portuguesa que, em 21 de abril, se mostrara um instrumento dócil nas mãos do príncipe regente. ${ }^{104}$
}

Quando as notícias da "Bernarda" de 5 de junho chegaram à Lisboa, em início de agosto, tal apreciação das tropas portuguesas foi reformulada e exaltada. Nesse contexto, ainda sem a presença da deputação brasileira, aos 21 de agosto a Comissão do Ultramar apresentava um parecer com as "linhas gerais do regime que se devia estabelecer para as

\footnotetext{
${ }^{101}$ NEVES, Lúcia M. Bastos Pereira das. op. cit., p. 258.

102 Apud NEVES, Lúcia M. Bastos Pereira das. op. cit., p. 259.

103 TOMAZ, Fernando. “Brasileiros nas Cortes constituintes de 1821-1822”. In: MOTA, Carlos Guilherme (org.). op. cit., p. 75.

${ }^{104}$ NEVES, Lúcia M. Bastos Pereira das. op. cit., p. 285
} 
relações com o Brasil"105. O parecer reconhecia as juntas provinciais ligadas ao governo de Lisboa e julgava desnecessária a presença de d. Pedro no Brasil, exigindo seu retorno e considerando "até indecorosa a demora de sua Alteza, o príncipe real, no Rio de Janeiro" ${ }^{106}$. Buscando enfraquecer qualquer concentração de poder no Brasil, o parecer também recomendava a extinção de todos os tribunais superiores no ultramar, retirando as prerrogativas de Reino Unido concedidas ao Brasil em 1815, submetendo-o a uma única autoridade central em Lisboa.

Nem todos os deputados portugueses foram favoráveis às medidas anunciadas no parecer, gerando intenso debate. Quanto ao envio de tropas ao Brasil, muitos mostraramse receosos, acreditando não ser possível nem necessária a submissão do país pela força, sobretudo após os “sucessos” conseguidos pela Divisão portuguesa frente ao príncipe em 5 de junho. Deputados como Manuel Fernandes Thomás acreditavam que os descontentamentos dos brasileiros eram direcionados unicamente aos malefícios do Antigo Regime, de forma que desapareceriam tão logo a "sábia Constituição" fosse elaborada. Na visão deste deputado e de outros que o apoiavam, o "mito da Constituição, aplicada igualmente aos brasileiros e portugueses, evitava qualquer possibilidade de uma opressão colonial", de forma que a Lei superaria qualquer diferença entre "europeus" e "americanos"107. Para Valentim Alexandre, embora os deputados portugueses reconhecessem “uma certa 'fermentação de ideias' e a existência de um 'partido da Independência' no Rio" ${ }^{108}$, consideravam ser este um movimento residual, destinado a desaparecer com a instauração do regime constitucional:

\footnotetext{
Segundo os "regeneradores", a extensão ao Brasil da mesma Constituição, a aplicação aos brasileiros das leis, direitos e garantias concedidos a portugueses, eliminava qualquer possibilidade de exercício, pelas Cortes, de uma opressão de tipo colonial. Integrando-se no tronco comum da nação, as províncias brasileiras acenderiam à liberdade, na medida em que contribuíam para a formação da vontade geral, consubstanciada na lei. (...) Esta concepção permitia articular ideologicamente os princípios liberais com o restabelecimento da hegemonia portuguesa (através de uma "vontade geral" em cuja formação a metrópole teria um peso determinante). ${ }^{109}$
}

\footnotetext{
105 Idem.

${ }^{106}$ Ibidem, p. 286.

${ }^{107}$ Ibidem, p. 287, grifo nosso.

${ }^{108}$ ALEXANDRE, Valentim. “O nacionalismo vintista...”. op. cit., p. 296.

${ }^{109}$ Idem.
} 
Nesse sentido, a forte motivação nacionalista que caracterizou a regeneração vintista impossibilitou a percepção do Brasil, por parte de Portugal, como uma entidade autônoma, reduzindo a opressão colonial ao despotismo com que o antigo sistema tinha administrado o território brasileiro ${ }^{110}$. Aos 29 de setembro de 1821, as Cortes aprovariam decretos com as medidas do parecer, sem contar, contudo, com grandes objeções dos poucos brasileiros que se encontravam presentes. Nem os deputados fluminenses, nem os pernambucanos - bancadas já assentadas - levantaram-se contra as medidas, nem mesmo quando da determinação da "remoção" de d. Pedro do Brasil. Gomes de Carvalho comenta o silêncio da deputação brasileira diante da discussão dos decretos:

Os americanos não formularam protesto mais tímido contra a medida que dissociava as províncias; os próprios fluminenses conservaram-se quedos, não sentindo a degradação da categoria de capital resultante do berço com a destruição da regência e a perda iminente dos tribunais. ${ }^{111}$

Como explicar a postura dos deputados brasileiros? Simples "miopia intelectual", timidez ou convergência de interesses e objetivos entre os deputados dos dois lados do Atlântico? De fato, não parecia haver divergências entre os portugueses da Europa e da América no sentido de que buscavam a preservação da integridade do Império lusobrasileiro. Lúcia Neves demonstrou, mediante análise de folhetos políticos e periódicos da época, que somente a partir do segundo semestre de 1821 começam a surgir os primeiros textos que tomavam o partido da Independência. Até então, mesmo as figuras mais radicais como Gonçalves Ledo e José Clemente Pereira, por meio de seu jornal Revérbero Constitucional Fluminense, evitavam falar em separação política dos dois reinos, devido à forte influência da noção de indissolubilidade do Império no imaginário das elites da época.

Além do mais, com a demora na comunicação entre Portugal e Brasil, sendo necessário "por volta de seis a oito meses para as notícias irem e voltarem através do Atlântico" ${ }^{112}$, os deputados pernambucanos e fluminenses acreditavam estar decretando nada mais, nada menos, que a vontade dos "brasileiros" - ou dos portugueses americanos -, apenas sancionando "o que fora estabelecido espontaneamente pelos povos do Brasil no ato de aclamação do regime constitucional"113. Afinal, a população já havia eleito

\footnotetext{
${ }^{110}$ NEVES, Lúcia M. Bastos Pereira das. op. cit., p. 287.

111 CARVALHO, Manuel E. Gomes de. op. cit., p. 83.

${ }^{112}$ NEVES, Lúcia M. Bastos Pereira das. op. cit., p. 285.

${ }^{113}$ GOMES, Manuel E. Gomes de. op. cit., p. 83.
} 
juntas governativas a fim de acatar ordens vindas diretamente de Lisboa, e não da autoridade do príncipe regente. Até mesmo o combativo jornalista Hipólito da Costa não deixou de aceitar as resoluções das Cortes:

Se a estada de S.A.R. no Brasil tendesse a formar um centro comum de união entre aquelas províncias e as de Portugal, a retirada que se ordena pelas Cortes seria para lamentar; mas pelo que se tem passado vemos que para a desejada união é preciso recorrer a outras medidas; e assim a sua residência no Brasil vem, neste sentido, a ser perfeitamente inútil. ${ }^{114}$

Desta feita, aprovaram-se os decretos de 29 de setembro que regulamentavam a organização política do território luso-brasileiro, voltando Portugal a ocupar a posição central dentro do Império. Saía vitoriosa a corrente favorável à hegemonia de Portugal, mantendo-se a união entre este país e o Brasil, cuja visão permaneceria dominante nas Cortes nos meses subsequentes, “embora submetida a uma pressão cada vez maior, com a evolução dos acontecimentos no Brasil e com as novas posturas apresentadas pelos deputados brasileiros" $" 115$.

Após a "Bernarda", cresceria o antagonismo entre portugueses e brasileiros no Rio de Janeiro, de forma que as notícias dos decretos de 29 de setembro aportaram na cidade, em inícios de dezembro, sob uma atmosfera de descontentamento e hostilidades. Cada vez mais definiam-se e separavam-se as identidades de portugueses e brasileiros, estes comprometidos com a "causa do Brasil". De forma geral, os portugueses mostravam-se favoráveis às determinações da Cortes e amparavam-se nas tropas da Divisão portuguesa ancoradas no Rio; já os brasileiros preocupavam-se com a sorte do Brasil e receberam negativamente as medidas de Lisboa, consideradas "recolonizadoras", sobretudo porque viam na permanência de d. Pedro a chance de acenderem ao poder. Em ofício de 24 de outubro, o barão de Mareschal apontava dois partidos como responsáveis pela afixação de cartazes e pasquinas pelas ruas do Rio de Janeiro: um, português, acusava o príncipe regente de querer se tornar independente junto com os brasileiros; outro, brasileiro, exortava a todos a se libertarem do "jugo das Cortes e da soldadesca"116.

Portanto, não é de se espantar que a repercussão do decreto das Cortes no Rio de Janeiro viesse a provocar o clamor geral da população e o acirramento das disputas entre

\footnotetext{
${ }^{114}$ Correio Braziliense, vol. 27, p. 431-432, novembro de 1821 apud SOBRINHO, Barbosa Lima. op. cit., p. 336.

115 NEVES, Lúcia M. Bastos Pereira das. op. cit., p. 289.

${ }^{116}$ Apud NEVES, Lúcia M. Bastos Pereira das. op. cit., p. 289.
} 
os dois "partidos" antagônicos. Segundo Emília Viotti da Costa, "as decisões tomadas pelas Cortes repercutiram no Brasil como uma declaração de guerra, provocando tumultos e manifestações de desagrado"117. Na percepção do manifesto contemporâneo Despertador Brasiliense:

As notícias, que há pouco nos chegavam de Lisboa, têm produzido uma fermentação tão grande e tão geral nos ânimos dos habitantes desta cidade, que é muito para recear ocasionarem desordens de não pequena monta. ${ }^{118}$

O autor do manifesto denunciava as atitudes do Congresso, afirmando que os brasileiros haviam sido enganados, uma vez que "estavam eles convencidos de que abraçando a causa de Portugal nada perderiam da sua representação política", pelo contrário, achavam que "ganhariam muito, não só pela reforma dos males, que são inerentes ao Governo Despótico, e absoluto, como também pela requisição de novos direitos civis, e políticos"119. Porém, o que se sucedia era que as Cortes fomentavam "o Cisma político que tão propício lhes era para estenderem a sua influência neste vasto Continente", transformando as províncias do Brasil em províncias de Portugal, mandando tropas, subordinando as juntas administrativas à Lisboa, extinguindo os tribunais e, por fim, fruto de um "ciúme mal-entendido mandam recolher agora com toda brevidade possível, e sem terem consultado primeiro a parte mais importante da Nação, o nosso Amável Príncipe, o único apoio que restava a nossas esperanças" 120.

Tratava-se, enfim, de uma tentativa de ver "as nossas belas e florescentes Províncias reduzidas ao universal estado de Colônias". A única saída para o Brasil, que já havia perdido seu rei - "talvez mal aconselhado, e por interesses particulares de seu Ministério" -, seria confiar no príncipe regente, "o penhor das suas esperanças"; ele jamais consentiria com a medida das Cortes, considerada "ilegal, injuriosa e impolítica". O próprio d. Pedro confessaria em carta ao pai temer que a "opinião pública” o impedisse de cumprir os decretos:

Dou parte a Vossa Majestade que a publicação dos decretos fez um choque mui grande nos brasileiros e em muitos europeus aqui estabelecidos, a ponto de dizerem pelas ruas: "Se a Constituição

\footnotetext{
${ }^{117}$ COSTA, Emília Viotti da. "Introdução ao estudo da emancipação...”. op. cit., p. 47.

118 Apud CARVALHO, José Murilo de; NEVES, Lúcia M. Bastos Pereira das; BASILE, Marcelo (orgs.). Guerra literária... vol. 2 (Análises), op. cit., p. 120.

${ }^{119}$ Apud CARVALHO, José Murilo de; NEVES, Lúcia M. Bastos Pereira das; BASILE, Marcelo (orgs.). Guerra literária... vol. 2 (Análises), op. cit., p. 120.

${ }^{120}$ Apud CARVALHO, José Murilo de; NEVES, Lúcia M. Bastos Pereira das; BASILE, Marcelo (orgs.). Guerra literária... vol. 2 (Análises), op. cit., p. 121.
} 
é fazer-nos mal, leve o Diabo a tal cousa, havemos fazer um termo para o príncipe não sair, sob pena de ficar responsável pela perda do Brasil para Portugal, e queremos ficar responsáveis por ele não cumprir os dois decretos publicados". ${ }^{121}$

Outro folheto, intitulado $O$ Brasil indignado contra o projeto anticonstitucional sobre a privação das suas atribuições, por um filopátrico, escrito no início de 1822, mas certamente anterior ao dia do "Fico", também critica a postura das Cortes. Afirma que a vinda da Família Real em 1808 teria concedido ao Brasil a "carta de sua emancipação", gerando "um grande ciúme"122 em Portugal, que tratou de armar

todos os planos para o privarem da Coroa, de todas as suas atribuições e darem-lhe um pobre chapéu de grosseira palha; era bem de esperar que os seus Deputados fossem chamados para assistirem mudos, e com os braços cruzados à sanção das Leis, que em tábuas de pedras deviam trazer ao Brasil: era bem de esperar enfim que a menor oposição de nossa parte fosse considerada como um atentado de Lesa-Nação. ${ }^{123}$

Quando os brasileiros acudiram ao grito da regeneração portuguesa deram provas de sua fidelidade, inclusive "deixaram com lágrimas sair dos seus braços o Senhor d. João VI, esperando que a Sua Presença no Soberano Congresso (...) apertasse mais e mais os laços de nossa união, e servisse de penhor à permanência de nossas atribuições" ${ }^{124}$. Porém, as Cortes haviam retribuído com "providências anticonstitucionais a nosso respeito" e basta apenas anunciá-las para perceber que são "inteiramente opostas às ideias liberais de qualquer Constituição", levantando "suspeitas sobre as vistas pouco favoráveis que se começam a lançar contra nós" ${ }^{25}$. Entre as providências a serem tomadas, o autor sugeria, primeiramente, que se enviassem

a nossos Deputados instruções decisivas sobre o verdadeiro objeto de sua representação a fim de que se estabeleça nossa união Constitucional, sem a mais pequena, sem a mais ligeira suspeita de ofensa daquelas direitos, que nós não podemos perder

\footnotetext{
${ }^{121}$ Carta de d. Pedro a d. João, 14 de dezembro de 1821 apud JÚNIOR, Augusto de Lima. op. cit., p. 39.

${ }^{122}$ Apud CARVALHO, José Murilo de; NEVES, Lúcia M. Bastos Pereira das; BASILE, Marcelo (orgs.). Guerra literária... vol. 2 (Análises), op. cit., p. 358-359.

${ }^{123}$ Apud CARVALHO, José Murilo de; NEVES, Lúcia M. Bastos Pereira das; BASILE, Marcelo (orgs.). Guerra literária... vol. 2 (Análises), op. cit., p. 360.

${ }^{124}$ Apud CARVALHO, José Murilo de; NEVES, Lúcia M. Bastos Pereira das; BASILE, Marcelo (orgs.). Guerra literária... vol. 2 (Análises), op. cit., p. 360.

${ }^{125}$ Apud CARVALHO, José Murilo de; NEVES, Lúcia M. Bastos Pereira das; BASILE, Marcelo (orgs.). Guerra literária... vol. 2 (Análises), op. cit., p. 363-364.
} 
porque são constitutivos de nossa experiência política e moral na hierarquia dos povos civilizados. ${ }^{126}$

Em segundo lugar, sugeria o "empenho mais decidido pela conservação da Sua Alteza Real no Brasil", juntamente com um "Conselho Deliberativo" formado por "Deputados de todas as nossas Províncias centrais", escolhidos entre "a classe dos homens mais conhecedores deste Continente", que sancionaria "o plano de regulamento" mais apropriado para o país. Novamente, a esperança residia na figura do príncipe regente - que "nós dá as mais lisonjeiras esperanças de uma prosperidade inalterável"127 -, acrescido de um elemento novo, o germe de um Conselho de Procuradores, de caráter deliberativo, e não mais consultivo, o qual seria convocado tempos depois, através do decreto de 16 de fevereiro de 1822.

Outra reação imediata aos decretos das Cortes foi o aparecimento de representações das províncias do Rio de Janeiro, São Paulo e Minas Gerais solicitando a permanência do príncipe regente no Brasil. Essas representações intentavam convencer d. Pedro - que até então mostrava-se resistente quanto a desobedecer às ordens das Cortes - de que sua conservação no país evitaria a separação dos dois Reinos e, consequentemente, a desintegração do território nacional em republiquetas, como acontecia na América hispânica. Segundo Lúcia Neves, o Senado da Câmara do Rio de Janeiro, não julgando prudente que a província fizesse "a representação por si só, porque não havia força necessária, muito mais existindo no Rio de Janeiro uma força portuguesa assaz forte"128, convocaria a cooperação das províncias de Minas Gerais e São Paulo.

Nesse sentido, aos 29 de dezembro, elaborou-se um Manifesto do Povo do Rio de Janeiro sobre a residência de S. A. Real no Brasil expondo os motivos para "suspender a execução do Decreto das Cortes sobre o regresso de Sua Alteza Real para a antiga Sede da Monarquia Portuguesa". O texto afirmava que o "Brasil, conservado na sua categoria, nunca perderá de vista as ideias de seu respeito para com a sua ilustre e antiga metrópole, nunca se lembrará de romper esta cadeia de amizade e de honra" que liga os dois Reinos. Contudo, protestava contra os decretos do Congresso, alegando que só a presença do príncipe garantiria a união das províncias do Brasil e dos dois Continentes:

\footnotetext{
${ }^{126}$ Apud CARVALHO, José Murilo de; NEVES, Lúcia M. Bastos Pereira das; BASILE, Marcelo (orgs.). Guerra literária... vol. 2 (Análises), op. cit., p. 366-367.

${ }^{127}$ Apud CARVALHO, José Murilo de; NEVES, Lúcia M. Bastos Pereira das; BASILE, Marcelo (orgs.). Guerra literária... vol. 2 (Análises), op. cit., p. 367.

${ }^{128}$ Apud NEVES, Lúcia M. Bastos Pereira das. op. cit., p. 294-295.
} 
O povo do Rio de Janeiro, conhecendo bem que estes são os sentimentos de seus coirmãos, protesta à face das nações pelo desejo que tem de ver realizada esta união, tão indispensável para consolidar as bases da prosperidade nacional; entretanto, o mais augusto penhor da infalibilidade destes sentimentos é a pessoa do príncipe real no Brasil, porque nela reside a grande ideia de toda aptidão para o desempenho destes planos, como o primeiro vingador do sistema constitucional. ${ }^{129}$

Ao final do manifesto, seguiam-se oito mil assinaturas. Em 8 de janeiro, o Senado da Câmara do Rio de Janeiro, temeroso de que houvesse alguma reação por parte Divisão Auxiliadora, favorável ao regresso de d. Pedro à Portugal, publicou um edital com instruções aos fluminenses que quisessem apresentar representações, "que devem subir à presença de Sua Alteza Real”. O edital preocupava-se em manter a ordem pública, rogando ao povo para que não houvesse nenhum incidente, recomendando a todos que "se conservem em boa paz e não soltem vozes, nem vivas de qualquer natureza, e que confiem no mesmo Senado, que desempenhará perfeitamente os seus desejos"130.

Ao meio dia de 9 de janeiro, o Senado da Câmara, por meio de seu presidente José Clemente Pereira e de "homens bons" e muitos cidadãos, dirigiu-se até o Paço da cidade para a entrega do manifesto a d. Pedro. Na vigorosa fala que precedeu à entrega, o presidente

uma vez mais advertia que a partida do príncipe real seria "o fato decreto que [sancionaria] a independência deste reino", criticando o Congresso, ao mesmo tempo, por ter principiado a decretar medidas para o Brasil antes que todos os seus deputados estivessem reunidos, em desacordo com as bases da Constituição. ${ }^{131}$

Descrevia a situação de forma dramática: relembrava a Revolução de 1817 em Pernambuco, afirmando que a província poderia se levantar novamente em razão "das matérias-primas da Independência que um dia proclamou"; citava também Minas Gerais e São Paulo, províncias que agiam com grande autonomia, sendo que esta última manifestara "sobejamente (...) os sentimentos livres que possui nas políticas instruções que ditou aos seus ilustres deputados". Por fim, denunciava a existência de um "partido da Independência que não dorme”, que se aproveitaria da ausência de d. Pedro para

\footnotetext{
${ }^{129}$ Manifesto do povo do Rio de Janeiro sobre a residência de S. A. Real no Brasil, dirigida ao Senado da Câmara, s/ página, grifo nosso, disponível em: http://www.efecade.com.br/1821-manifesto-do-povo-dorio-de-janeiro/. Acesso: 02/12/2015.

${ }^{130}$ Apud NEVES, Lúcia M. Bastos Pereira das. op. cit., p. 295.

${ }^{131}$ NEVES, Lúcia M. Bastos Pereira das. op. cit., p. 296.
} 
efetivar suas ideias separatistas. A única solução estava sendo protestada pela opinião pública: "Dê-se ao Brasil um centro próximo de união e atividade; dê-se-lhe uma parte do corpo legislativo e um ramo do poder executivo [para que] possa Portugal e o Brasil fazer sempre uma família irmã, um só povo, uma só nação e um só Império" ${ }^{132}$.

Naquele momento, portanto, a permanência do príncipe d. Pedro no Brasil, negligenciando-se as ordens advindas das Cortes de Lisboa, representava não a sua Independência frente à Portugal, mas sim a única possibilidade de se manterem unidos os dois países. Era o ideal de uma monarquia dual, solução apoiada por grande parte das elites brasileiras da época que não desejavam o retorno do Brasil à condição colonial, mantendo-se, assim, os direitos e a autonomia conquistados desde a abertura dos portos às nações amigas, em 1810, e de sua elevação à Reino Unido, em 1815. Não se aspirava, ainda, à separação política daquele reino luso, considerada uma ponte importante entre o Brasil e o "mundo civilizado" da Europa.

Ou seja, diante dos decretos das Cortes que, do ponto de vista dos brasileiros, cerceavam a autonomia do Brasil, o "partido brasileiro"133 se insurgiu contra o Soberano Congresso, sentindo-se ludibriado. O golpe final teria sido o decreto exigindo o retorno de d. Pedro, que acabaria por despojar o Brasil de um membro da monarquia, retornando à condição colonial anterior a 1808. Temia-se que a ausência de uma autoridade central no Rio de Janeiro quebrasse o elo que unia as províncias do Brasil, que a esta altura se mostrava bastante frágil. Entretanto, não se propunha a separação definitiva entre os dois reinos, a não ser como último recurso, caso o Congresso continuasse adotando posturas intransigentes e insistisse em rebaixar o Brasil ao estado de colônia. Somente assim seria inevitável - embora lamentável - quebrar os grilhões e ferros da escravidão brasileira.

Segundo Cecília de Salles Oliveira, "no início do século XIX, independência não se confundia com a emancipação e autonomia administrativa”, apesar de essa identificação "se acentuar no decorrer do século". A transferência da sede da monarquia para o Brasil e a elevação deste à condição de reino eram consideradas, "por diferentes interlocutores do jogo político na América, entre 1821 e 1822, o reconhecimento, de fato e de direito, da autonomia das diversas partes do território", entendendo-se que o Brasil “não só era autônomo como ocupava estatuto igual ao de Portugal”. É por isso que era viável a possibilidade “de que a Independência pudesse ser alcançada sem que os vínculos

\footnotetext{
${ }^{132}$ Apud NEVES, Lúcia M. Bastos Pereira das. op. cit., p. 296.

${ }^{133}$ Os partidos políticos do período da Independência serão estudados mais detalhadamente no capítulo 2.
} 
com Portugal fossem rompidos"134, pelo menos até as vésperas da Independência formal do país, catalisada pelos decretos "recolonizadores"135 das Cortes.

"União" e "Independência", portanto, constituiriam o discurso político do Brasil na transição entre os anos 1821 e 1822. Até os últimos meses de 1821 e a chegada das notícias dos decretos provenientes de Lisboa, as palavras de ordem da imprensa e dos folhetos políticos eram união e integridade do Império luso-brasileiro. Contudo, a partir de dezembro daquele ano, houve "mudança nas palavras e ideias que divulgavam a linguagem política, constituindo-se um novo ideário relacionado a algumas propostas de separatismo"136. Redefiniram-se alguns pontos essenciais da cultura política com o (res)surgimento de um vocabulário político que ia dando forma à noção de Independência. Porém, a ideia separatista, ainda em 1822, aparecia como uma medida extrema que se devia evitar. Mesmo as folhas mais radicais como o Revérbero Constitucional Fluminense, às vésperas do grito do Ipiranga, relutavam em falar em separação:

Ainda nenhum brasileiro disse: eu não quero Constituição; nenhum exclamou também: separemo-nos da Mãe Pátria; mas o capricho de alguns deputados nas Cortes de Lisboa tem-nos grandemente aproximado de um termo, em que os brasileiros todos gritaremos unânimes: temos pátria, temos Constituição, temos Rei e bastante denodo para defendermos a nossa liberdade, para conservarmos as nossas leis e a nossa política gloriosa de representação nacional. ${ }^{137}$

Segundo a análise do historiador José Honório Rodrigues,

durante os primeiros meses de 1822 discutiu-se muito esta questão política, da união ou a separação, e suas vantagens e desvantagens. As posições foram-se extremando, e aos brasileiros foi-se tornando claro que não havia vantagem na união, pois o Brasil podia passar sem Portugal, e as Cortes não queriam reconhecer a perfeita igualdade de direitos. ${ }^{138}$

\footnotetext{
134 OLIVEIRA, Cecília H. de Salles. op. cit., p. 20.

135 A historiografia brasileira convencionou chamar os decretos das Cortes que restituíam a posição hegemônica da metrópole no Império português de "recolonizadores". Cf., por exemplo, COSTA, Emília Viotti da. "Introdução ao estudo da emancipação"... op. cit.; RODRIGUES, José Honório. Independência... A emancipação política, v. 1. op. cit.; NEVES, Lúcia M. Bastos Pereira das. op. cit.; HOLANDA, Sérgio Buarque de; CAMPOS, Pedro Moacyr (dirs.). História Geral da Civilização Brasileira. O Brasil Monárquico. O processo de emancipação, t. II, v. 1. 4ª ed. São Paulo: Difusão Europeia do Livro, 1974.

${ }^{136}$ NEVES, Lúcia M. Bastos Pereira das. op. cit., p. 199.

137 Revérbero Constitucional Fluminense, n 15, 3 de setembro de 1822 apud NEVES, Lúcia M. Bastos Pereira das. op. cit., p. 199.

${ }^{138}$ RODRIGUES, José Honório. Independência... A emancipação política, v. 1. op. cit., p. 227.
} 
Significativa também é a mudança de postura de d. Pedro frente às pressões da opinião pública, como pode ser apreendido de sua correspondência com o pai. Em carta datada de 15 de dezembro, descrevia as representações do Rio de Janeiro, Minas Gerais e São Paulo, resumindo seu teor deste modo: “Ou vai [para Portugal], nós nos declaramos independentes, ou fica [no Brasil], e então continuamos a estar unidos e seremos responsáveis pela falta de execução das ordens do Congresso". Deixava claro, porém, que "só a força será capaz de me fazer faltar ao meu dever", assinando, como sempre fazia, "seu súdito fiel e filho obedientíssimo, que lhe beija a sua real mão - Pedro"139. Já em 2 de janeiro, o príncipe mudaria o tom: "Farei todas as diligências por bem para haver sossego e para ver se posso cumprir os decretos $\mathrm{n}^{\circ} .124$ e 125, o que me parece impossível, porque a opinião é toda contra por toda a parte" ${ }^{140}$.

Sete dias depois, aos 9 de janeiro, assim que recebeu da comitiva do Senado da Câmara o manifesto pedindo sua permanência no Brasil, d. Pedro descreveria a seu pai a sua célebre resposta: "Como é para bem de todos e felicidade geral da Nação, estou pronto, diga ao povo que fico". Continuava sua carta, contando que após receber "imensos vivas", teria recomendado ao povo "união e tranquilidade"141. Curioso notar que, após a reunião, um edital do Senado da Câmara fora afixado nos lugares públicos contendo um relato um pouco diferente daquele que o príncipe fizera a seu pai; segundo o edital, d. Pedro teria se mostrado bastante hesitante:

Convencido de que a presença de minha pessoa no Brasil interessa ao bem de toda a nação portuguesa e conhecendo que a vontade de algumas províncias o requer, demorarei minha saída até que as Cortes e meu augusto pai e senhor deliberem a este respeito com perfeito conhecimento das circunstâncias que têm ocorrido. ${ }^{142}$

Todavia, no dia seguinte, outro edital do Senado da Câmara veio à luz, declarando ter publicado na véspera, "com notável alteração de palavras", a resposta do príncipe. Pedia desculpas ao público e justificava o erro nascido unicamente "do transporte de alegria que se apoderou de todos que estavam no salão de audiências". Retificava a resposta, substituindo-a pela célebre frase: “diga ao povo que fico”. Para Lúcia Neves, o erro foi fruto da própria indecisão de d. Pedro, "preocupado em garantir a segurança da

\footnotetext{
${ }^{139}$ Carta de d. Pedro a d. João, 15 de dezembro de 1821 apud LIMA JÚNIOR, Augusto de. op. cit., p. 40.

${ }^{140}$ Carta de d. Pedro a d. João, 2 de janeiro de 1822, grifo nosso, apud LIMA JÚNIOR, Augusto de. op. cit., p. 42.

${ }^{141}$ Carta de d. Pedro a d. João, 9 de janeiro de 1822 apud LIMA JÚNIOR, Augusto de. op. cit., p. 43.

142 Apud NEVES, Lúcia M. Bastos Pereira das. op. cit., p. 297.
} 
nação portuguesa com sua permanência, mesmo se em desobediência às Cortes e ao pai, mas ainda não comprometido com a Independência do Brasil"143. José Honório Rodrigues, por sua vez, acredita na identificação do jovem d. Pedro com o país:

O que teria feito d. Pedro mudar em tão poucos dias? O processo de transformação de sua personalidade política nada sofrera, e sim seus novos valores e novos objetivos, enfim, sua identificação com o país, aonde chegara com nove anos e quatro meses, e onde vivera até os 23 anos, que tinha então. A retirada de d. Pedro do processo de opressão portuguesa, do seu supremo esforço de conservação colonial, como o denominou Oliveira Lima, decidia a revolução em favor do Brasil. ${ }^{144}$

Independentemente dos motivos, o "Fico" acelerou a marcha da emancipação política do Brasil. Porém, naquele momento, na percepção das elites - grandes interessadas nos rumos políticos do país, haja vista a possibilidade de acenderem ao poder -, não obstante as conotações separatistas que iam surgindo, a data assegurava a preservação da ideia de um único e integrado Império luso-brasileiro. Embora anunciado como o "dia regenerador", as fontes da época "são parcimoniosas quanto à contribuição do Fico no desencadeamento de um ideal separatista", focando muito mais nas críticas às Cortes. Os escritos, em sua grande maioria, continuavam "propugnando por uma 'união de todos os portugueses de ambos os hemisférios" "145.

Para as tropas portuguesas, contudo, a resposta do príncipe soou como um desafio à autoridade das Cortes e o primeiro passo para a separação política dos dois reinos. Oficiais da Divisão Auxiliadora ameaçaram levar d. Pedro preso, à ponta de suas espadas, para embarcar rumo a Portugal. Soldados foram vistos arrancando os editais afixados pelo Senado da Câmara e, na noite de 11 de janeiro, quebraram as vidraças das janelas que se haviam iluminado em comemoração à decisão do príncipe. "O clima de animosidade sinalizava o prenúncio de uma nova Bernarda, semelhante às que tinham ocorrido em 26 de fevereiro e 5 de junho de $1821 "$ " Escreveu d. Pedro ao pai que o general Avilez fora aos quartéis no dia 11 "dizer falsamente aos soldados que estava demitido do governo das armas, e que assim ele sentia muito deixar um comando que tanto o honrava"147. Narrava as vidraças quebradas pelos soldados e os gritos de "Viva o general constitucional!" que ecoavam pelas ruas. Descrevia, a seguir, a reação da "tropa da terra, milícia e povo" que

\footnotetext{
${ }^{143}$ NEVES, Lúcia M. Bastos Pereira das. op. cit., p. 298.

${ }^{144}$ RODRIGUES, José Honório. Independência... A evolução política, v. 1. op. cit., p. 193.

${ }^{145}$ NEVES, Lúcia M. Bastos Pereira das. op. cit., p. 299.

${ }^{146}$ Ibidem, p. 300.

${ }^{147}$ Carta de d. Pedro a d. João, 23 de janeiro de 1822 apud LIMA JÚNIOR, Augusto de. op. cit., p. 44.
} 
também pegaram em armas "e não se quiseram desarmar sem que a Divisão se desarmasse" $" 148$.

Enfrentaram-se no Campo de Santana, no Rio de Janeiro, de um lado, a Divisão Auxiliadora, composta por cerca de 1600 homens que afirmavam querer a "unidade e indivisibilidade da monarquia"; de outro, um número cada vez maior de pessoas que afluíam para o local, "em um entusiasmo geral pela causa da Nação". Este último grupo somava algo em torno de quatro a seis mil homens, "pela maior parte destituídos de disciplina, mas animados todos de um espírito verdadeiramente patriótico e marcial" ${ }^{149}$. A iminente guerra civil levou d. Pedro a enviar a princesa e seus filhos para a fazenda de Santa Cruz e a interferir, mais uma vez, pessoalmente nos acontecimentos. No dia 12 de janeiro, respaldado pelas tropas brasileiras concentradas no Campo de Santana, d. Pedro encontrou-se com os oficiais da Divisão portuguesa, convencendo-os a embarcarem para Praia Grande (atual Niterói), com o objetivo de eliminar a "indisposição geral que [havia] entre as tropas de Portugal e as desta cidade, querendo poupar quanto esteja de sua parte a efusão de sangue" ${ }^{\prime 150}$. A ameaça que pairava o Rio de Janeiro enfim dissipava-se.

Este episódio, juntamente com o "Fico", demonstrava que o Rio de Janeiro começava a agir independentemente de Lisboa, aproximando-se cada vez mais da emancipação política. Ademais, pela primeira vez desde 26 de fevereiro de 1821, a regência de d. Pedro no Brasil via-se livre da coerção militar portuguesa. Os decretos "recolonizadores" das Cortes e a reação violenta da Divisão Auxiliadora acabaram por acirrar a animosidade entre portugueses e brasileiros, que se desiludiam cada vez mais com a ideia de Império luso-brasileiro:

Ressentida a opinião pública com as atitudes das Cortes e de seus agentes, convencida a elite política da necessidade de garantir uma autonomia para o Brasil e decidido d. Pedro a libertar-se do jugo do Congresso de Lisboa, lançavam-se enfim as bases do movimento separatista. ${ }^{151}$

É por isso que Cecília de Salles Oliveira pondera que, no Brasil de início dos anos 1820, já havia o reconhecimento, por parte “dos protagonistas da Independência e da construção do Estado imperial"152, de uma tangibilidade da nação, cada vez mais

\footnotetext{
${ }^{148}$ Carta de d. Pedro a d. João, 23 de janeiro de 1822 apud LIMA JÚNIOR, Augusto de. op. cit., p. 45.

${ }^{149}$ Apud NEVES, Lúcia M. Bastos Pereira das. op. cit., p. 301.

${ }^{150}$ Apud NEVES, Lúcia M. Bastos Pereira das. op. cit., p. 302.

${ }^{151}$ NEVES, Lúcia M. Bastos Pereira das. op. cit., p. 305.

152 OLIVEIRA, Cecília Helena L. de Salles. "Estado, nação e escrita da História: propostas para debate". In: CARVALHO, José Murilo de; NEVES, Lúcia M. Bastos Pereira das (orgs.). op. cit., p. 241.
} 
identificada como comunidade nacional emergente, distinta da nação portuguesa. A "Causa do Brasil" começava a ser tutelada pelas elites políticas e até mesmo pelo príncipe português, futuro Imperador. Segundo essa historiadora,

no início da década de 20 , a cena política teria abrigado o aparecimento da nação que, investindo contra o Estado de caráter absolutista, imprimiu outros rumos aos negócios públicos, dada a construção de espaços para o exercício da liberdade política pelos cidadãos. E, se num primeiro desdobramento, a nação se constituiu dos dois lados do Atlântico, o respaldo conferido ao projeto separatista promoveu uma mudança de percurso, redefinindo-se internamente à América portuguesa o pacto que então se instaurava. ${ }^{153}$

Outro resultado do enfrentamento das tropas portuguesas e brasileiras foi a nomeação de um novo ministério, aos 16 de janeiro. Apesar de ser considerado o "primeiro gabinete nacional”, somente José Bonifácio de Andrada e Silva (ministro do Reino e dos Estrangeiros) era brasileiro, natural de Santos; Caetano Pinto de Miranda Montenegro (Fazenda e Justiça), Joaquim de Oliveira Alvares (Guerra) e Manuel Antônio Farinha (Marinha), o único remanescente do antigo ministério, eram todos portugueses. Foi esse gabinete, liderado pelo icônico José Bonifácio, que impulsionaria d. Pedro a bradar, às margens do Ipiranga, o grito de Independência.

\section{Os brasileiros clamam antes por uma "Assembleia brasílica" do que pela Independência}

"A política do príncipe regente junto ao novo ministério (...) tinha como objetivo fundamental impor d. Pedro como efetivo governante do Reino do Brasil, ainda que reconhecendo a soberania de d. João VI"154. Para tanto, a primeira atitude do novo gabinete foi enfraquecer a Divisão portuguesa, ainda acantonada em Praia Grande, "concedendo baixas aos soldados, fazendo-os alistar-se no Brasil, sitiá-la, impedi-la de qualquer ação" 155 , até que embarcasse definitivamente de volta para Portugal em 17 de fevereiro.

Mal empossado no cargo de ministro, José Bonifácio teria sido o mentor do decreto de 21 de janeiro, que ordenava ao desembargador do Paço que, daquela data em

\footnotetext{
${ }^{153}$ Ibidem, p. 247.

${ }^{154}$ NEVES, Lúcia M. Bastos Pereira das. op. cit., p. 314.

${ }^{155}$ RODRIGUES, José Honório. Independência... A evolução política, v. 1. op. cit., p. 227.
} 
diante, "não fizesse remessa a repartição alguma das leis vindas de Portugal, sem que fossem antes submetidas ao conhecimento do príncipe regente", de forma que este, ““achando-se análogas às circunstâncias’ do Brasil, determinasse a sua execução”. Outro decreto de 30 do mesmo mês concitava os governos provisórios de todas as províncias a promoveram a união mediante a "sujeição à regência de d. Pedro"156.

Aos 16 de fevereiro, um novo decreto, também atribuído ao ministro, criaria o Conselho de Procuradores Gerais das Províncias do Brasil. Tratava-se de uma espécie repaginada de Conselho de Estado, que seria presidida pelo príncipe regente, embora pudesse ser convocada extraordinariamente por seus membros. Segundo Emília Viotti da Costa, o Conselho surgia para

analisar as decisões das Cortes e examinar a sua aplicabilidade ao Brasil, bem como promover dentro dos limites impostos pelo Poder Executivo as reformas e melhoramentos necessários à prosperidade e desenvolvimento do território brasileiro. ${ }^{157}$

Enquanto a adesão do Rio de Janeiro à causa do príncipe parecia inquestionável, sobretudo após o despacho da Divisão Auxiliadora para Portugal, o mesmo não se pode dizer das outras províncias, especialmente as do Norte e Nordeste. As maiores resistências vieram da Bahia e do Maranhão, que se declaravam inteiramente favoráveis às Cortes de Lisboa e que interpretaram o decreto de 16 de fevereiro como um "embrião de uma Assembleia Legislativa, que conflitava o Soberano Congresso e a própria representação brasileira presente nesse órgão"158. O Conciliador do Maranhão, transcrevendo artigo do Semanário Cívico da Bahia, questionaria a funcionalidade do decreto:

Como é que uma província, a qual tem em Cortes os seus deputados ou procuradores para cuidarem na formação das leis e prosperidade geral da Nação, e, em particular, da sua respectiva província, mande agora ao Rio de Janeiro novos procuradores para cuidarem do mesmo objeto? Esta contradição salta aos olhos: é admitir na mesma causa dois juízes e haver dois poderes legislativos: porque, ou os procuradores, que mandarmos para o Rio, juntos com o príncipe, têm autoridade para fazerem as novas reformas, que precisa o Brasil, ou não: no primeiro caso, usurpam o poder legislativo das Cortes e são rebeldes à Constituição; e, no segundo caso, se tornam estes nulos e desnecessários. ${ }^{159}$

\footnotetext{
${ }^{156}$ SOUZA, Octávio Tarquínio de. História dos Fundadores do Império do Brasil, vol. 1 (A vida de José Bonifácio), $2^{\text {a }}$ ed. Rio de Janeiro: José Olympio, 1957, p. 179.

157 COSTA, Emília Viotti da. "José Bonifácio: homem e mito". In: MOTA, Carlos Guilherme (org.). op. cit., p. 124.

${ }^{158}$ NEVES, Lúcia M. Bastos Pereira das. op. cit., p. 318

${ }^{159}$ Apud NEVES, Lúcia M. Bastos Pereira das. op. cit., p. 319.
} 
Para assegurar a adesão de todas as províncias que resistiam a se submeter à autoridade do príncipe e do Rio de Janeiro, José Bonifácio enviaria "emissários com a incumbência de aliciar entre as categorias dominantes elementos que oferecessem o apoio necessário" ${ }^{160}$, aconselharia d. Pedro a viajar para Minas Gerais a fim de garantir fidelidade e mandaria tropas à Bahia para combater o general Madeira, que só sairiam vitoriosas em 2 de julho ${ }^{161}$. Segundo José Honório Rodrigues, se d. Pedro mostrava-se hesitante até então, após sua importante viagem a Minas Gerais teria decidido, finalmente, pela causa brasileira. "Tinha-se completamente naturalizado brasileiro, e de tal começou a ufanar-se perante seu próprio pai. Bastava ler suas cartas (...) para ver que ele era agora mais brasileiro que português"162. A unidade nacional em torno de um centro único de poder - o Rio de Janeiro - ia aos poucos e sob duras penas sendo conquistada.

Após a bem-sucedida viagem de d. Pedro a Minas Gerais ${ }^{163}$, os deputados mineiros eleitos ao Soberano Congresso resolveram adiar sua viagem a Lisboa, justificando que preferiam ficar no Brasil a "engrossar o número de deputados do ultramar, que assaz pequeno para a pluralidade vencedora, seria contudo suficiente para sancionarem a escravidão do nosso país" ${ }^{\prime 64}$. Essa postura foi seguida pelo deputado eleito pelo Espírito Santo, João Bernardino de Almeida. Em março, dava-se mais um passo rumo à emancipação política com a proibição do desembarque de tropas portuguesas no Rio de Janeiro, enviadas para substituir a Divisão Auxiliadora. Em carta ao pai, d. Pedro justificaria sua atitude afirmando que "se desembarcasse a tropa, imediatamente o Brasil se desunia de Portugal e a Independência me faria aparecer bem contra a minha vontade por ver a separação", completando que assim garantia "a elevação do Brasil a Reino,

\footnotetext{
${ }^{160}$ COSTA, Emília Viotti da. "José Bonifácio: homem e mito”... op. cit., p. 124.

161 Para os movimentos de resistência à centralização do poder nas mãos de d. Pedro, cf. MOTA, Carlos Guilherme (org.). op. cit., especialmente caps. 9 (Norte), 10 (Nordeste), 11 (Bahia), 12, (Goiás), 13 (Minas Gerais), 15 (São Paulo) e 16 (Rio Grande do Sul); NEVES, Lúcia M. Bastos Pereira das. op. cit., p. 315334; MELLO, Evaldo Cabral de. A outra Independência. O federalismo pernambucano de 1817 e 1824. São Paulo: Editora 34, 2004.

${ }^{162}$ RODRIGUES, José Honório. Independência... A emancipação política, v. 1. op. cit., p. 232, amparandose em Varnhagen.

163 José Honório Rodrigues escreveu sobre a importância da viagem do príncipe a Minas Gerais. Desconfiava-se, à época, de que havia uma conspiração em uma das mais importantes e ricas províncias brasileiras. Com a viagem de d. Pedro e as sucessivas "falas aos briosos mineiros", o príncipe havia desmantelado a conspiração, substituindo membros do governo mineiro, e garantido a adesão da província ao movimento levado a cabo pelo Rio de Janeiro e por São Paulo: "A viagem de d. Pedro foi um triunfo, obtendo apoio mineiro por toda a parte. Só em Vila Rica, é que triunfara a facção separatista. (...) Mas não houve coragem para enfrentar o príncipe, apoiado pelo povo e pelas milícias que o acompanhavam, e a submissão foi total". RODRIGUES, José Honório. Independência... A emancipação política, v. 1. op. cit., p. 230-233.

${ }^{164}$ Apud NEVES, Lúcia M. Bastos Pereira das. op. cit., p. 332.
} 
donde nunca descerá" ${ }^{165}$. A posição do príncipe era clara: a união entre as duas nações só seria possível enquanto mantida a autonomia política e econômica adquirida pelo Brasil com a sua elevação a Reino, em 1815.

Enquanto isso, em março e abril de 1822, chegavam à Lisboa as notícias da desobediência de d. Pedro aos decretos do Congresso, da proibição do desembarque das tropas portuguesas e da incipiente mobilização brasileira para concentrar em território americano, além do poder Executivo (personificado na figura do príncipe), uma parcela do poder Legislativo, por meio do Conselho de Procuradores. Para a opinião pública portuguesa, a antiga colônia transformara-se "no filho ingrato que recusava os benefícios da regeneração política"166. Tanto para os deputados portugueses, quanto para a imprensa lusa, os protestos vindos do Brasil "reduziam-se a mera conspiração contra o regime liberal, desconhecendo-se aí quaisquer aspirações autênticas" ${ }^{" 167}$.

O drama da emancipação política atingia seu clímax. Pela primeira vez, os redatores do Revérbero Constitucional Fluminense admitiam, de forma clara e explícita, a possibilidade de criação de um Império exclusivamente brasileiro:

Sim, Príncipe, rasguemos o véu dos mistérios, rompa-se a nuvem que encobre o sol, que deve raiar na esfera do Brasil. Eleva, eleva o templo da Liberdade brasileira; forme-se nele o livro da lei, que nos deve reger (...) o Deus dos cristãos, a Constituição brasílica e Pedro, eis os nossos votos (...) Príncipe, só assim baquearão de uma vez os cem dragões que rugem e procuram devorar-nos... Não desprezeis a gloria de ser o fundador de um novo Império. ${ }^{168}$

Até mesmo Hipólito José da Costa, ferrenho defensor do ideário do grande Império luso-brasileiro, converteu-se à "causa do Brasil” após os decretos regeneradores para uns, recolonizadores para outros - das Cortes. Em fevereiro de 1822 já denunciava que os deputados portugueses conspiravam "para que o Brasil continue em sujeição a Portugal" e descrevia com entusiasmo a atuação dos deputados brasileiros, que começavam a se impor nas Cortes:

O Deputado de São Paulo, Andrada [Antônio Carlos de Andrada Machado e Silva, irmão de José Bonifácio], respondeu-lhe cabalmente que (...) o Brasil não continuará mais a ser colônia de Portugal, e que se declarará independente tanto mais depressa,

\footnotetext{
165 Carta de d. Pedro a d. João, 14 de março de 1822, grifo nosso, apud LIMA JÚNIOR, Augusto de. op. cit., p. 59.

${ }^{166}$ NEVES, Lúcia M. Bastos Pereira das. op. cit., p. 311.

${ }^{167}$ Ibidem, p. 335.

${ }^{168}$ Apud NEVES, Lúcia M. Bastos Pereira das. op. cit., p. 340.
} 
quantas mais forem as medidas, que as Cortes adotarem para o conservar no estado de sujeição. ${ }^{169}$

Em abril, Hipólito da Costa lamentaria os procedimentos das Cortes concernentes ao Brasil, os quais haviam forçado "mudar também nosso modo de raciocinar" quanto à insustentável união entre Portugal e Brasil:

É chegado o tempo de entrar seriamente no exame da importante medida da união dos dois Reinos de Portugal e do Brasil, que tanto temos recomendado, e a que infelizmente as Cortes, em Lisboa, não tem prestado aquela atenção que na nossa opinião este poderoso objeto merece. (...) Enquanto estivemos persuadidos que os erros cometidos pelas Cortes eram involuntários e acidentais, sempre nos achamos dispostos a passar por eles; mas quando nos convencemos, que eram efeito de sistema, que constantemente se não tem desmentido, forçoso nos foi mudar também nosso modo de raciocinar. ${ }^{170}$

Paralelamente, no Rio de Janeiro, mais um passo se dava em direção à emancipação política do Brasil. A iniciativa partira novamente do Senado da Câmara daquela cidade, que articularia para que d. Pedro fosse agraciado com o título de Protetor e Defensor Perpétuo do Brasil, aos 13 de maio, quando se festejava o aniversário de d. João VI. Apresentada ao príncipe a aclamação, d. Pedro aceitou apenas o título de Defensor Perpétuo do Brasil, recusando o de Protetor, justificando que "o Brasil não precisa da proteção de ninguém, protege-se a si mesmo”. Identificava-se, cada vez mais, como brasileiro e defensor da "Causa do Brasil", escrevendo ao pai sobre a ocasião: "Defenderei o Brasil que tanto me honrou, como a V. M., porque tal é o meu dever como brasileiro e como príncipe" ${ }^{171}$. Uma vez agraciado com o título de Defensor Perpétuo, "a autoridade do príncipe deixava de derivar exclusivamente de um poder hereditário para ser confirmada pela vontade popular"172, que mais tarde também o coroaria e aclamaria Imperador.

Por esta época ganhava força, através da imprensa e da opinião pública, a necessidade de reunião de um Congresso brasiliense concomitantemente às Cortes de Lisboa. Somente uma representação totalmente nacional seria capaz de produzir o melhor "regulamento" para o Brasil, adequado a suas necessidades. O Conselho de Procuradores

\footnotetext{
${ }^{169}$ Correio Braziliense, v. 28, fevereiro de 1822, p. 269-280 apud LIMA SOBRINHO, Barbosa. op. cit., p. 379-380

${ }^{170}$ Correio Braziliense, v. 28, abril de 1822, p. 472-475 apud LIMA SOBRINHO, Barbosa. op. cit., p. 389.

${ }^{171}$ Apud RODRIGUES, José Honório. Independência... A evolução política, v. 1. op. cit., grifo nosso, p. 234.

${ }^{172}$ NEVES, Lúcia M. Bastos Pereira das. op. cit., p. 340.
} 
passou a ser visto como um embrião de uma Assembleia Legislativa, que ainda por cima ajudava a garantir a unidade das províncias do Brasil. Segundo José Honório Rodrigues, o Conselho de Procuradores não fora recebido, "nos meios liberais", como uma "medida satisfatória", posto que apresentava apenas caráter consultivo, "e cada vez mais se pensava na necessidade de criar-se no Brasil um poder Legislativo" ${ }^{173}$. Os liberais propugnavam que a "nova ordem de coisas" só era compatível com conselhos deliberativos, e não apenas consultivos, ganhando força a defesa de uma Assembleia Legislativa. Alguns veículos da imprensa, ligados a esses liberais, foram os grandes defensores dessa ideia. O Correio do Rio de Janeiro, editado pelo polêmico João Soares Lisboa, foi um dos periódicos que empreendeu forte campanha pela convocação de Cortes no Brasil:

Concidadãos, a nossa liberdade está em perigo, nosso risco é iminente, o remédio deve ser pronto e legal. Temos o mais legítimo de todos os legítimos poderes executivos, na pessoa do nosso regente; não podemos dispensar-nos de ter o Legislativo. Só gozando os mesmos direitos e liberdade que gozam os nossos irmãos de Portugal, podemos conservar com ele a união. Só assim seremos como eles felizes. Seja uma voz de todos e representemos ao nosso regente que queremos, porque precisamos, já, já e já, Cortes, Cortes e Cortes. ${ }^{174}$

Em carta ao pai, d. Pedro narraria o "justo" e "muito constitucional" pedido dos brasileiros, o qual não se recusaria a acatar:

É necessário que o Brasil tenha Cortes suas; esta opinião generaliza-se cada dia mais. O povo desta capital prepara uma representação que me será entregue para suplicar que as convoque, e eu não posso a isso recusar-me, porque o povo tem razão, é muito constitucional... Sem Cortes o Brasil não pode ser feliz. As leis feitas tão longe de nós, por homens que não são brasileiros, e que não conhecem as necessidades do Brasil, não poderão ser boas... O Brasil deve ter Cortes (...) não posso recusar este pedido do Brasil porque é justo, funda-se no direito das gentes, é conforme os sentimentos constitucionais, oferece enfim mais um meio para manter a união, que de outro modo breve cessará inteiramente. Sem igualdade de direito, em tudo e por tudo não há união. ${ }^{175}$

${ }^{173}$ RODRIGUES, José Honório. Independência... A evolução política, v. 1. op. cit., p. 234.

${ }^{174}$ Correio do Rio de Janeiro, $\mathrm{n}^{\circ}$ 29, 22 de abril de 1822 apud NEVES, Lúcia M. Bastos Pereira das. op. cit., p. 344.

${ }^{175}$ Carta de d. Pedro a d. João, 21 de maio de 1822 apud RODRIGUES, José Honório. Independência... A evolução política, v. 1. op. cit., p. 236. 
Em um primeiro momento, pensava-se ainda na possibilidade de uma "monarquia dual", mantendo-se as duas Coroas unidas, se bem que com poderes Legislativos autônomos. Aos 23 de maio, o Senado da Câmara do Rio de Janeiro redigia uma representação para que fosse convocada uma Assembleia Geral das Províncias do Brasil "com o objetivo, entre outros, de deliberar sobre as justas condições com que o Brasil deveria permanecer unido a Portugal" ${ }^{176}$. O documento, elaborada pelo grupo de Ledo ${ }^{177}$ - que defendia, sem sucesso, desde o incidente na praça do Comércio de 26 de fevereiro de 1821, que se formasse um órgão de representação popular -, insistia na eleição direta dos deputados à Assembleia, que teria como atribuição examinar as ordens advindas de Lisboa e estabelecer as alterações necessárias para sua aplicação no Brasil. Não se falava, ainda, em Cortes constituintes, embora se tratasse, sem dúvida, de um poder Legislativo derivado da soberania popular.

Na audiência com o príncipe, o então presidente do Senado da Câmara do Rio de Janeiro, José Clemente Pereira, declararia que "se a Lei Suprema da Salvação da Pátria exigiu a Ficada de V.A.R. neste Reino, como remédio único de o conservar unido, esta mesma lei impera, hoje, que se convoque já nesta Corte uma Assembleia”. Segundo José Honório Rodrigues, a fala detalhava o plano da convocação, as atribuições da Assembleia e enumerava as muitas queixas do Brasil às Cortes, e finalizava, profético: "Está escrito, no Livro das leis eternas, que o Brasil deve passar hoje, oh! Grande Dia! À lista das Nações livres"178. Joaquim Gonçalves Ledo, eleito procurador da cidade do Rio de Janeiro, reiterou a necessidade de convocação de uma Assembleia brasílica em reunião do Conselho de Procuradores, a 3 de junho:

Senhor. A Salvação Pública, a Integridade da Nação, o Decoro
do Brasil, a Glória de Vossa Alteza Real instam, urgem e
imperiosamente comandam que Vossa Alteza Real faça convocar
com a maior brevidade possível uma Assembleia Geral dos
Representantes das Províncias do Brasil (...) Não precisamos,
Senhor, neste momento fazer a enumeração das desgraças com
que o Congresso [de Lisboa], postergando os mesmo princípios
que lhe deram nascimento, autoridade e força, ameaçava as ricas
províncias deste Continente. A Europa, o Mundo todo que as tem

${ }^{176}$ COSTA, Emília Viotti da. "Introdução ao estudo da emancipação...". op. cit., p. 49.

177 O grupo de Ledo é formado por personalidades políticas que se reuniram em torno de Joaquim Gonçalves Ledo, comerciante fluminense, como Januário da Cunha Barbosa, José Clemente Pereira e João Soares Lisboa. Tratar-se-á mais detidamente sobre os grupos políticos da Independência no capítulo 2 desta dissertação.

${ }^{178}$ Apud RODRIGUES, José Honório. Independência... A evolução política, v. 1. op. cit., p. 236. 
observado as conhece (..) O Brasil já não pode, já não deve esperar que de alheias mãos provenha a sua felicidade. ${ }^{179}$

Reafirmava, por meio de uma frase aparentemente paradoxal, mas que, à época, fazia muito sentido entre as elites brasileira que "o Brasil quer independência, mas firmada sobre a União bem entendida com Portugal'. Para tanto, era urgente a convocação de uma Assembleia Geral, entendida como a "Âncora que pode segurar a Nau do Estado, a Cadeia que pode ligar as Províncias do Brasil ao Trono de Vossa Alteza Real" ${ }^{180}$. Nesse sentido, percebe-se que a convocação de uma "Assembleia brasílica" surgia como solução tanto para a garantia de manutenção dos direitos e da autonomia do Brasil ante Portugal, quanto para a conservação da união entre as províncias do país. D. Pedro, por sua vez, "ciente da vontade do Rio de Janeiro desde 23 de maio, apenas aguardava que se pronunciassem as Câmaras ou os procuradores" ${ }^{181}$, e assim feito, anuiu ao pedido. Baixou decreto no mesmo dia convocando uma Assembleia Geral, Constituinte e Legislativa composta de deputados de todas as províncias do Brasil, que deveriam ser eleitos conforme instruções a serem fixadas. Foi o decreto do príncipe que falou, pela primeira vez, em Cortes Constituintes no Brasil, ampliando os poderes legislativos dos deputados.

Enquanto a ala mais radical do liberalismo brasileiro, o grupo de Ledo, instava por uma Assembleia Legislativa, de certo apta a revisar e produzir uma legislação aplicável à nação brasileira, mantendo-se a Constituição portuguesa como dispositivo regulador supralegal, o príncipe português convocaria uma Assembleia Legislativa e Constituinte. Dessa forma, ampliavam-se os poderes da primeira experiência parlamentar nacional brasileira que, além da obra legislativa, estaria investida de elaborar a primeira Constituição do Brasil.

A polêmica, que tomou os jornais e folhetos políticos, bem como opôs os homens mais próximos ao príncipe naquele momento, travou-se em torno do formato das eleições às Cortes. Em sessão do Conselho dos Procuradores aos 10 de junho, Gonçalves Ledo defenderia eleições diretas, seguindo o exemplo do pleito ao Congresso lisbonense. Pautava sua posição na Representação entregue pelo Senado da Câmara do Rio de Janeiro aos 23 de maio. Dos 2.982 assinantes do documento, 2.545 optaram por eleições diretas, 11 por eleições indiretas e 426 não se manifestaram a respeito ${ }^{182}$. Aconselhava, portanto,

\footnotetext{
179 BRASIL. Atas do Conselho de Estado. Conselho dos Procuradores Gerais das Províncias do Brasil, 1822-1823. (Direção: José Honório Rodrigues). Brasília: Senado Federal, 1973, p. 7-8.

${ }^{180}$ Ibidem, p. 8.

${ }^{181}$ NEVES, Lúcia M. Bastos Pereira das. op. cit., p. 348

${ }^{182}$ Ibidem, p. 349.
} 
que o príncipe ouvisse a opinião pública, que se mostrava a favor da nomeação direta: "É do meu dever aconselhar Vossa Alteza Real que se não oponha à torrente impetuosa da opinião pública, não se irritem ânimos, que começam a acalmar-se" ${ }^{\text {183 }}$. A ele opôs-se o procurador de Minas Gerais, Estevão Ribeiro de Rezende, que apresentou projeto de eleições semidiretas, ancorado no pressuposto de que os votantes no Brasil eram ignorantes e poderiam causar tumultos. Posto em votação, o Conselho de Procuradores decidiu-se pela adoção do método de eleições indiretas. Aos 19 de junho, da pena de José Bonifácio saíam as instruções, indicativas da vitória de uma postura mais moderada e menos democrática.

Lúcia Neves é incisiva ao destacar que a convocação para as Cortes brasílicas causou maior efusão de júbilo na imprensa do que a própria Independência “oficial”, aos 7 de setembro. Comemorou-se o dia 3 de junho como aquele em que o Brasil acabava de "para sempre despedaçar as cadeias da escravidão", considerado o "magno aniversário, o dia natalício de sua Regeneração política" ${ }^{184}$. Louvava-se a atitude de d. Pedro como sendo "o passo mais acertado, que vai cobrir de glórias os brasileiros, tão indignamente desprezados no Congresso de Lisboa", o "eterno monumento do liberalismo do nosso Augusto Regente" ${ }^{185}$. Para os portugueses, a convocação de Cortes brasílicas foi considerada "o selo final da separação do Brasil e de Portugal, antes mesmo de sua proclamação oficial" ${ }^{186}$. Paradoxalmente e muito significativamente, as atitudes que, "do lado de cá do Atlântico apareciam como demonstração do constitucionalismo de d. Pedro, do lado de lá revelavam-se como tendências despóticas e anticonstitucionais" ${ }^{187}$. Cresciam os embates e confrontos entre os deputados portugueses e brasileiros no Congresso de Lisboa, chegando estes últimos a abandonarem seus assentos; segundo Gomes de Carvalho, a essa altura, os brasileiros “já nada esperavam do Congresso se não licença para se irem embora" 188 .

Ao longo dos meses de junho, julho e agosto, chegavam ao Rio de Janeiro as notícias de adesão das demais províncias do Brasil à regência constitucional de d. Pedro. Até mesmo a Bahia dava mostras de que caminhava cada vez mais para a expulsão do general Madeira e adesão ao governo regencial. Vários “atos hostis a Portugal”, cujo

\footnotetext{
183 BRASIL. Atas do Conselho de Estado... op. cit., p. 11.

184 Apud NEVES, Lúcia M. Bastos Pereira das. op. cit., p. 352.

185 Apud NEVES, Lúcia M. Bastos Pereira das. op. cit., p. 353.

${ }^{186}$ NEVES, Lúcia M. Bastos Pereira das. op. cit., p. 355.

${ }^{187}$ Ibidem, p. 360.

${ }^{188}$ CARVALHO, Manuel E. Gomes de. op. cit., p. 262.
} 
maior exemplo é o manifesto de $1^{\circ}$ de agosto, atribuído a Gonçalves Ledo, que considerava inimigas as tropas portuguesas e afirmava ser o rei d. João um prisioneiro das Cortes de Lisboa, "cavaram ainda mais o fosso da separação"189 entre as duas nações. O texto declarava a independência política do Brasil, embora ainda assegurasse as relações comerciais amigáveis entre os dois reinos. Outro manifesto endereçado às "nações amigas", datado de 6 agosto, dessa vez escrito por José Bonifácio, adotava uma postura mais moderada, proclamando a Independência do Brasil, "salvo a devida e

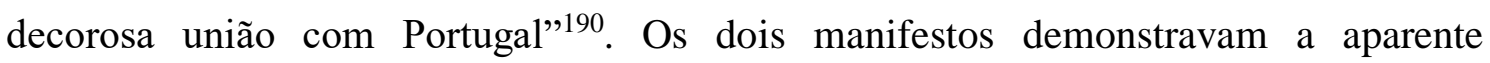
contradição do termo Independência, que "representava a autonomia política, mas não implicava obrigatoriamente a separação total de Portugal, até porque quem a decretara era o herdeiro natural da Coroa lusitana"191.

Em meio a esse clima político, os acontecimentos posteriores transformaram-se em formalidades do reconhecimento da separação. Em 28 de agosto de 1822, chegavam de Portugal as notícias das últimas medidas que o Soberano Congresso havia tomando com relação ao Brasil, a ponto de reduzir d. Pedro a um mero delegado das Cortes, com secretários de Estados nomeados por Lisboa, e a processarem José Bonifácio e o príncipe por insubordinação. As notícias foram remetidas ao regente por cartas da princesa Leopoldina - a esta altura presidente do Conselho de Procuradores, já que d. Pedro se achava em viagem a São Paulo - e de José Bonifácio. A carta da princesa afirmava que "as notícias de Lisboa são péssimas" e que o povo daquela cidade "tem-se permitido toda a qualidade de expressões indignas contra a sua pessoa", requerendo "com a maior brevidade" o retorno de d. Pedro, cuja "energia e rigor" eram a única forma de salvar o Brasil da ruína ${ }^{192}$. José Bonifácio escreveria ao príncipe no mesmo sentido:

Senhor, o dado está lançado: de Portugal não temos a esperar senão escravidão e horrores. Venha V.A.R. quanto antes e decida-se, porque insuflações e medidas dessas normas, à vista de um contrário que não nos poupa, para nada servem e um momento perdido é uma desgraça. ${ }^{193}$

As cartas do Rio de Janeiro chegaram em São Paulo na manhã de sábado, 7 de setembro. Conta o padre Belchior, acompanhante do príncipe em sua viagem, que d.

\footnotetext{
${ }^{189}$ RODRIGUES, José Honório. Independência... A evolução política, v. 1. op. cit., p. 238.

${ }^{190}$ Apud COSTA, Emília Viotti da. “Introdução ao estudo da emancipação...”. op. cit., p. 55.

${ }^{191}$ NEVES, Lúcia M. Bastos Pereira das. op. cit., p. 364.

192 Apud RODRIGUES, José Honório. Independência... A evolução política, v. 1. op. cit., p. 247.

${ }^{193}$ Apud RODRIGUES, José Honório. Independência... A evolução política, v. 1. op. cit., p. 249.
} 
Pedro, após ouvir a leitura das cartas recém-chegadas, "tremendo de raiva, arrancou de minhas mãos os papéis e, amarrotando-os, pisou-os, deixou-os na relva". Depois, abotoando-se e fardando-se, "pois vinha de quebrar o corpo à margem do riacho do Ipiranga, agoniado por uma desinteria, com dores, que o apanhara em Santos”, virou-se e respondeu:

As Cortes me perseguiram, chamam-me com desprezo de Rapazinho e de Brasileiro. Pois verão quanto vale um Rapazinho. De hoje em diante estão quebradas as nossas relações; nada mais quero do governo português e proclamo o Brasil para sempre separado de Portugal! ${ }^{194}$

Estava declarado o célebre "grito do Ipiranga", que hoje é solenizado como a data definitiva da Independência do Brasil. Porém, para os contemporâneos, segundo nos conta Lúcia Neves, "este ato não teve significado especial, não sendo sequer noticiado pela imprensa da época" ${ }^{195}$. Na verdade, os jornais já consideravam o Brasil como nação independente desde o decreto de 3 de junho (convocação da Assembleia Geral, Legislativa e Constituinte), ou, pelo menos, desde os manifestos de agosto de 1822. Restava, agora, iniciar a construção do edifício legal e político sobre o qual alicerçar-seia o Império brasileiro, enfim separado de Portugal.

194 Apud RODRIGUES, José Honório. Independência... A evolução política, v. 1. op. cit., p. 250.

195 NEVES, Lúcia M. Bastos Pereira das. op. cit., p. 370. 


\title{
Capítulo 2: Os atores dos debates sobre a liberdade religiosa na Constituinte de 1823
}

\begin{abstract}
Um Brasileiro liberal podia crer em 1817 ser necessário aderir a republicanos, que só então nos prometiam emancipação. Hoje, graças à Providência, S.A.R. conhece os seus verdadeiros interesses, e está convencido, que a emancipação do Brasil é o passo preliminar da sua prosperidade, e da glória do seu reinado, e tem desta maneira ajuntado em roda de si os verdadeiros patriotas. E desta arte obtendo-se na monarquia o mesmo que se buscava nas repúblicas federadas, não pasma que um republicano mude de partido. ${ }^{1}$
\end{abstract}

Desta forma defendeu-se o deputado às Cortes de Lisboa, Antonio Carlos Ribeiro de Andrada Machado e Silva, irmão de José Bonifácio, acerca das “mentirosas asserções” que o jornal luso Astro de Lusitânia havia publicado sobre ele. A imprensa lusitana, bem como alguns deputados portugueses ao Soberano Congresso, na tentativa de desqualificar um dos mais opinativos deputados brasileiros, lançou sobre Antonio Carlos um olhar de desconfiança, já que o deputado paulista havia participado da Revolução Pernambucana de 1817, de caráter republicano. Segundo Gomes de Carvalho, em sessão das Cortes de 20 de setembro de 1822, o deputado português Manoel Gonçalves de Miranda teria dito que "se havia constituinte a quem não cabia o labéu" era Antonio Carlos, que "aplaudira a Revolução de 1817 e por ela sofrera"². O Astro de Lusitânia também o atacara em razão de seu passado "democrático", ao que Antonio Carlos respondera, através de carta enviada ao Correio Braziliense:

\footnotetext{
Mas quero dar como certo, que [se] eu fosse conselheiro de S.A.R. onde está a contradição com os primeiros princípios, a que chama o Astro de democrático (sic)? Ignora alguém que a liberdade civil e política tanto pode dar-se em formas republicanas como nas monarquias representativas? ${ }^{3}$
}

\footnotetext{
${ }^{1}$ Declaração do deputado Antonio Carlos Ribeiro D'Andrada, sobre o que dele publicou em Lisboa o Astro da Lusitânia, 5 de novembro de 1822, Correio Braziliense, vol. 29, p. 547-549, novembro de 1822 apud LIMA SOBRINHO, Barbosa. Antologia do Correio Braziliense. Rio de Janeiro: Cátedra; Brasília: Instituto Nacional do Livro, 1977, p. 595.

${ }^{2}$ CARVALHO, Manuel E. Gomes de. Os deputados brasileiros nas Cortes Gerais de 1821. (1912) Brasília: Senado Federal, 1979, p. 264.

${ }^{3}$ Declaração do deputado Antonio Carlos... op cit., p. 595.
} 
Monarquia representativa, república, democracia e liberalismo: tais noções compunham o vocabulário político do Oitocentos em boa parte da Europa e da América, possibilitando o surgimento de diversos projetos políticos. Uma boa metáfora do longo e veloz século XIX seria, como apontaram Lilia Schwarcz e Heloisa Starling, a invenção da locomotiva, em 1804. Nas telas dos pintores William Turner e Claude Monet, ela surgia como

um fantasma escuro que rompia drasticamente a bruma da manhã, numa alusão aos prognósticos mais alvissareiros dos contemporâneos, certos de viverem numa época que representava o fim dos entraves do passado e, por suposto, das amarras com o atraso. ${ }^{4}$

A mentalidade vigente no século que irrompia era a de que "nada segurava as novidades e transformações estruturais que então se acumulavam", sobretudo após a agenda de fatos revolucionários que fecharam o Setecentos e que ampliaram o leque de projetos políticos possíveis. Em 1776, as treze colônias inglesas declararam sua independência da Grã-Bretanha, incorporando a noção de "república" à modernidade política e demonstrando que a condição colonial não era um estatuto perene. Ao longo do século XVIII, a Revolução Industrial iniciada na Inglaterra transformaria material e economicamente o mundo para sempre, por meio de inovações tecnológicas e de novas relações de trabalho. Em 1789, no final do século, era a vez da França empreender sua revolução, derrubando "o que parecia estável como a ordem da natureza", questionando a procedência divina da monarquia e todos os elementos que se relacionavam com o chamado Antigo Regime. Na América Central, a Revolução Haitiana (1791-1804) abolia a escravidão e formava a primeira república de africanos fora de seu continente, demonstrando que o sistema escravista também era uma "perversa circunstância histórica, e por isso mutável"5.

O início do século XIX, embora marcado por uma ação/reação conservadora, concretizado pela formação da Santa Aliança - coalizão formada pelos Impérios da Rússia, Áustria e Prússia que buscava frear o ímpeto revolucionário que tomava conta da Europa -, não conseguiu impedir a locomotiva das transformações estruturantes de seguir seu caminho. Os espaços de experiência acumulavam-se com uma rapidez nunca antes

\footnotetext{
${ }^{4}$ SCHAWRCZ, Lilia M.; STARLING, Heloisa M. Brasil: uma biografia. São Paulo: Companhia das Letras, 2015, p. 151.

${ }^{5}$ Ibidem, p. 151-152.
} 
presenciada, projetando com a mesma velocidade os horizontes de expectativas dos contemporâneos. As experiências limitam-se ao que foi experimentado no passado, podendo apenas ser recolhidas e recordadas, mas nunca revistas ou modificadas; já as expectativas são experimentadas de forma diferente, quer estejam carregadas de esperança ou medo: são passíveis de modificações, já que não passam de previsões, sem, contudo, perder de vista, em maior ou menor grau, as experiências que as geraram ${ }^{6}$.

A relação entre horizontes de expectativas e espaços de experiências é esclarecedora para pensarmos os grupos políticos que atuavam no Brasil nas primeiras duas décadas do Oitocentos preconizando o surgimento de diversos projetos políticos, ou, nas palavras de István Jancsó e João Paulo Pimenta, de "alternativas de futuro", engendradas a partir de "múltiplas identidades políticas" conflitantes ou complementares entre si. Para estes autores,

a instauração do Estado brasileiro se dá em meio à coexistência, no interior do que fora anteriormente a América portuguesa, de múltiplas identidades políticas, cada qual expressando trajetórias coletivas que, reconhecendo-se particulares, balizam alternativas de seu futuro. Essas identidades políticas coletivas sintetizavam, cada qual à sua maneira, o passado, o presente e o futuro das comunidades humanas em cujo interior eram engendradas, cujas organicidades expressavam e cujos futuros projetavam. Nesse sentido, cada qual referia-se a alguma realidade e a algum projeto de tipo nacional. ${ }^{7}$

Essas identidades políticas - unidades de "peças de um mosaico" - carregavam em si mais ou menos elementos de modernidade, sem, contudo, abandonar totalmente a tradição, que ainda moldava as expectativas de futuro, os usos do passado, e se fazia presente cotidianamente. Um exemplo significativo foi a manutenção da religião católica como culto oficial do nascente Império, que sequer foi questionada, apesar de ser anunciada sob os princípios do Iluminismo, reconhecidamente laico e anticlerical.

No que diz respeito especificamente aos projetos políticos defendidos pelos primeiros deputados constituintes do Brasil, o leque de expectativas ou de identidades políticas era amplo: iam de aspirações republicanas a monarquistas, passando por uma corrente mais democrática, que defendia a soberania popular, e outra mais conservadora

\footnotetext{
6 KOSELLECK, Reinhart. “'Espaço de experiência' e 'horizonte de expectativa': duas categorias históricas". In: Futuro passado: contribuição à semântica dos tempos históricos. Rio de Janeiro: Contraponto/PUC-Rio, 2006, p. 311-312.

7 JANCSÓ, István; PIMENTA, João Paulo G. Peças de um mosaico ou apontamentos para o estudo da emergência da identidade nacional brasileira. In: Revista de História das Ideias, vol. 21, 2000, p. 392.
} 
ou moderada, defensora da soberania da nação, partilhada entre os representantes da nação e o Imperador aclamado pelo povo. Em comum, porém, não admitiam o despotismo ou o absolutismo dos reis, traço característico do Antigo Regime e símbolo maior dos “entraves do passado". Era o triunfo do liberalismo, que moldava tanto as posturas mais radicais, quanto as mais moderadas - muito embora o cenário das "mitigadas Luzes portuguesas", como vimos, tenha identificado o despotismo mais na figura dos ministros do que na do próprio monarca. Foi nesse cenário de transformações estruturantes, se bem que mantidas as prerrogativas da autoridade real e da Igreja, que nasceram, formaram-se e atuaram os deputados que tomaram assento na Assembleia Geral, Legislativa e Constituinte do Império do Brasil, atores dos debates sobre a liberdade religiosa nesse momento de construção do edifício político e legal do Império.

\section{As elites políticas no contexto da Independência e na construção do edifício legal e político do Império}

Foi o historiador José Murilo de Carvalho, autor do já clássico livro A construção da ordem: a elite política imperial, que analisou a formação das elites políticas no Brasil Império. Segundo este autor, a elite imperial era bastante homogênea, menos por sua condição de classe e mais pelo fato de partilhar formas comuns de socialização (clubes, sociedades secretas, associações políticas), treinamento (educação superior na Universidade de Coimbra) e carreira (muitos eram funcionários públicos, elegendo-se deputados e posteriormente senadores, assumindo também como ministros). A "ideologia" que as elites partilhavam levavam-nas a agir de forma coesa, assumindo regimes de compromisso ao estilo de uma "modernização conservadora" ${ }^{8}$, que marcaria todo o período imperial.

Apesar e por conta da suposta homogeneidade da elite no Império, outros autores preocuparam-se em demonstrar suas clivagens internas. O próprio José Murilo de Carvalho reconheceu, no último capítulo de seu livro, a existência de tendências políticas diversas entre os membros das elites, que formariam os "partidos políticos imperiais" a partir da abdicação de d. Pedro, em 1831. Ilmar de Mattos também analisou dois "partidos" bem definidos ao longo do Segundo Reinado, os "saquaremas"

\footnotetext{
${ }^{8}$ CARVALHO, José Murilo de. A construção da ordem: a elite política imperial. Brasília: UnB, 1981, p.
} 32. 
(conservadores) e os "luzias" (liberais)"; Marcelo Basile, por sua vez, analisou as "tendências políticas" dos deputados da Regência, que se identificavam como caramurus, liberais exaltados ou liberais moderados ${ }^{10}$.

Com relação ao período da Independência e aos primeiros anos do governo de d. Pedro I, o delineamento das posições, tendências, facções ou partidos políticos torna-se mais complexo. Diante das significativas mudanças políticas que se desenrolaram entre 1820 e 1824, muitos grupos e alianças formaram-se e, de forma bastante fluída, desfizeram-se em questões de meses. Talvez o maior exemplo dessa "fluidez política" seja a trajetória dos Andradas, especialmente de José Bonifácio, que de ministro de d. Pedro passou a criticar sua postura através do jornal $O$ Tamoio, chegando a ser preso e exilado após a dissolução da Constituinte, em 1823, por ordens diretas do Imperador. O velho conselheiro seria reconduzido à cena política brasileira alguns anos depois como tutor do filho de d. Pedro, em meio à turbulência do período regencial.

Não obstante tal fluidez, alguns historiadores assumiram a tarefa de delimitar as tendências políticas atuantes no período da Independência e dos primeiros anos da formação do edifício político e legal do Primeiro Reinado. Caio Prado Júnior, por exemplo, buscou identificar as diferentes "forças políticas" polarizadas no Brasil após 1820. Para ele, existiam três grupos distintos: o primeiro, caracterizado como "revolucionário, democrático e liberal", representado pelas classes médias e baixas da população (excetuando-se os escravos, “cuja atitude será passiva”), formava a classe que mais ativamente sustentaria o movimento constitucionalista no Brasil. O segundo grupo era composto por indivíduos responsáveis pela "reação" à tendência revolucionária. Entre suas fileiras, encontravam-se elementos que defendiam "intransigentemente as prerrogativas reais", cujo expoente máximo seria o ministro Vilanova Portugal, bem como sujeitos "mais complacentes" que "aceitavam reformas da estrutura absolutista da monarquia", de forma a "aparar o poder real em seu benefício", como o conde de Palmela.

Um terceiro e último grupo seria o "partido brasileiro", que também tomaria o lado da "reação": "É um grupo menos definido e mais hesitante em suas atitudes. Formase daqueles que a permanência da Corte no Rio de Janeiro favorecera mais direta e

\footnotetext{
9 MATTOS, Ilmar Rohloff. O tempo saquarema: a formação do Estado Imperial. $2^{\mathrm{a}}$ ed. São Paulo: Haucitec, 1990.

${ }^{10}$ BASILE, Marcelo. "Deputados da Regência: perfil socioprofissional, trajetórias e tendências políticas". In: CARVALHO, José Murilo de; CAMPOS, Adriana Pereira (orgs.). Perspectivas de cidadania no Brasil Império. Rio de Janeiro: Civilização Brasileira, 2011, p. 87-122.
} 
largamente"11. Teria se alinhado em razão de interesses mercantis e financeiros diretamente ligados à conservação da Corte no Brasil, e buscavam apenas a "consolidação da posição alcançada" através de algumas reformas, mas jamais de revolução. Após a partida de d. João e de sua comitiva reacionária, esse partido se veria "só e isolado no campo da reação", inclinando-se, portanto, para a Independência, a fim de "impedir o contágio revolucionário e o progresso da democracia no Brasil" ${ }^{12}$. Passaram a se reunir ao redor do Clube da Resistência, enquanto os democratas fizeram-se ouvir através do Revérbero Constitucional Fluminense. Segundo Caio Prado Júnior, a "atitude inábil das Cortes" teria levado esses dois grupos a se unirem, momentaneamente, em favor da separação política entre Brasil e Portugal:

A ideia de separação ganha terreno entre os próprios democratas, que são afinal arrastados em bloco por ocasião dos acontecimentos do Fico. Realiza-se então a unificação das forças políticas brasileiras na base de um programa de emancipação do país. ${ }^{13}$

Embora a análise de Caio Prado Júnior fosse bastante inovadora para o seu tempo, na visão de Gladys Ribeiro faltavam-lhe, porém, “elementos para melhor definir aqueles que chama de democratas, de reacionários e os participantes do partido brasileiro"14. Cecília de Salles Oliveira, por sua vez, oferece-nos um estudo mais aprofundado do grupo a que Caio Prado denominou "revolucionário, democrático e liberal". Em seu livro $A$ astúcia liberal, a autora demonstra que os representantes dessa força política eram proprietários de lavouras comerciais e donos de engenho do Recôncavo e de Goitacazes, no Rio de Janeiro, bem como alguns negociantes atacadistas, burocratas e comerciantes varejistas que a eles se aliaram. Seus principais interlocutores formaram o chamado "grupo de Ledo", e incluíam, além do próprio Joaquim Gonçalves Ledo, Januário da Cunha Barbosa, José Clemente Pereira, Luís Pereira da Nóbrega de Souza Coutinho e Manuel dos Santos Portugal.

Tratavam-se de "homens que, desde fins do século XVIII, buscavam construir fortunas e ascender à esfera pública". Ao longo do governo joanino, aproveitando-se da

\footnotetext{
${ }^{11}$ PRADO JÚNIOR, Caio. “O Tamoio e a Política dos Andradas na Independência do Brasil”. In: A evolução política do Brasil e outros estudos. 12a ed. São Paulo: Brasiliense, 1980, p. 181-182.

${ }^{12}$ Ibidem, p. 184.

${ }^{13}$ Idem.

${ }^{14}$ RIBEIRO, Gladys Sabina. "Nação e cidadania no jornal O Tamoio. Algumas considerações sobre José Bonifácio, sobre a Independência e sobre a Constituinte de 1823”. In: cidadãos: modernidade política, 1822-1930. São Paulo: Alameda, 2008, p. 40. (org.). Brasileiros $e$
} 
reorganização da monarquia, passaram a ocupar cargos de maior influência, graças a relações pessoais e comerciais. No início da década de 1820, articularam "no interior das repartições do governo e das tropas" ${ }^{15}$, amparados pelos jornais Revérbero Constitucional Fluminense e Correio do Rio de Janeiro, um movimento de oposição à continuidade da política imposta pelos setores que concentravam o poder na Corte e na província. "Ou seja, contestavam o domínio exercido por nobres emigrados”"16, como Tomás Antônio Vilanova Portugal, por altos burocratas e pelas famílias mais poderosas do Rio de Janeiro, como a de Nogueira da Gama, Carneiro de Campos e Carneiro Leão.

Em busca de maior controle sobre a regulamentação do mercado interno, de forma a favorecer seus interesses comerciais, o grupo de Ledo, em um primeiro momento, aproximou-se das reivindicações dos liberais vintistas no sentido da “"regeneração' da monarquia, da partilha do poder e da construção de um novo governo que representasse a nação portuguesa"17. É por isso que a primeira manifestação articulada pelos liberais fluminenses - contando com o apoio da tropa portuguesa -, ocorrida na madrugada de 26 de fevereiro de 1821, resultou na adesão do Rio de Janeiro ao movimento constitucionalista português, exigindo o reconhecimento das Cortes de Lisboa, a adoção imediata da Constituição de Cádiz, a substituição dos ministros de d. João e a eleição de uma Junta de governo eleita pelo povo para acompanhar os próximos passos políticos.

Por considerarem que os nobres emigrados e os altos burocratas pretendiam a continuidade das instituições "antigas" colocavamse na condição de defensores da "felicidade da nação", identificada com a construção de um governo representativo que estreitasse as relações entre os dois reinos. Ou seja, nesse momento, a expressão "independência nacional" aparecia associada à proposta de atuação conjunta dos liberais em Portugal e no Rio de Janeiro no sentido da derrubada das leis e instituições que sustentavam a monarquia absoluta e o poder dos "grandes do reino". ${ }^{18}$

Outra manifestação organizada pelo grupo de Ledo, o incidente na praça do Comércio, de 21 de abril de 1821, configurou-se em nova tentativa de os liberais ascenderem ao poder. Gonçalves Ledo e Clemente Pereira procuraram transformar a reunião dos eleitores em uma Assembleia Legislativa, a fim de pressionarem por

\footnotetext{
15 OLIVEIRA, Cecília Helena L. de Salles. A astúcia liberal. Relações de mercado e projetos políticos no Rio de Janeiro (1820-1824). Bragança Paulista: EDUSF/Ícone, 1999, p. 107.

${ }^{16}$ Ibidem, p. 108.

${ }^{17}$ Idem.

${ }^{18}$ Ibidem, p. 113.
} 
mudanças, tais como "indicar homens de confiança que representassem suas proposições em Portugal; promover a definitiva partida da Família Real; e compor uma Junta de governo no Rio de Janeiro eleita pelos legítimos representantes do 'povo""19. Porém, à medida em que a Assembleia foi se tornando mais democrática e que o "povo" começou a efetivamente querer tomar parte do processo político, as contradições do grupo de Ledo revelaram-se:

Ao mesmo tempo em que Ledo e Clemente Pereira, entre outros, afirmavam os direitos naturais de todos os homens livres, negavam a possibilidade de os homens livres agirem por iniciativa própria e independente. Nas manifestações de fevereiro, o "povo" foi qualificado de "ordeiro", agindo de forma "legítima" ao concentrar-se nas ruas da cidade, mas, por ocasião dos acontecimentos de abril, foi apontado como "plebe", "turba", "populaça desenfreada", cujas reivindicações eram absurdas e desorganizadoras da "ordem". 20

Desta forma, Cecília de Salles Oliveira demonstrou que o rótulo de "democráticos" ou de "defensores da soberania popular", conferida ao grupo de Ledo tanto por seus inimigos, quanto pela historiografia tradicional, não representava, de fato, os reais interesses desse grupo - pelo menos não neste momento. A fluidez e ambiguidade de seu posicionamento político ficam em evidência no episódio do "Fico", aos 9 de janeiro de 1822. De acordo com a autora, os liberais posicionaram-se contrários à permanência de d. Pedro no Brasil porque acreditavam que a desobediência aos decretos das Cortes traria riscos à unidade do Império português, bem como permitiria que seus adversários políticos permanecessem no poder ao redor do príncipe. Clemente Pereira, a esta altura presidente do Senado da Câmara do Rio de Janeiro, diante das pressões da opinião pública, se viu obrigado a assumir a iniciativa de apresentar a d. Pedro a representação do povo fluminense exigindo a sua permanência no Brasil. Contudo, nos bastidores, "não se desfizeram as tratativas para evitar a concretização do "Fico"” por parte do grupo de Ledo. Cecília de Salles Oliveira sugere uma nova associação entre os liberais e as tropas portuguesas que, aos 11 de janeiro, protestaram contra a decisão do príncipe de ficar no Brasil, dando início a uma "guerra civil" no Campo de Santana. Nesse jogo político se observa a "astúcia liberal” do grupo de Ledo, já que, segundo a avaliação da historiadora,

\footnotetext{
${ }^{19}$ Ibidem, p. 132.

${ }^{20}$ Ibidem, p. 147.
} 
caso a resistência fosse derrotada - o que efetivamente ocorreu Clemente Pereira e seus companheiros de luta não poderiam ser acusados diretamente de se posicionarem contra o "Fico" (...) a reunião das tropas no centro da cidade, para todos os efeitos, fora efetuada pelos chefes da Divisão portuguesa. ${ }^{21}$

A partir da derrota no episódio do "Fico", os liberais reorganizaram-se e acabaram por perceber a "importância política de d. Pedro e o apoio do 'povo' ao príncipe"22, aproximando-se, enfim, do regente. Com a reformulação do ministério, que trazia à cena uma nova figura, o paulista José Bonifácio, e o decreto que convocava o Conselho de Procuradores (16 de fevereiro), Ledo e seu grupo vislumbraram uma nova oportunidade para assumirem o poder. De fato, Gonçalves Ledo elegeu-se procurador do Rio de Janeiro, atuando enfim no governo da Regência. Comenta Cecília de Salles Oliveira que "não foi casual o fato de, em maio de 1822, a produção do Revérbero", anteriormente feita em uma tipografia particular, "tenha sido transferida para a Tipografia Nacional" 23.

A função social dos jornais, periódicos e panfletos foi analisada por diversos autores $^{24}$. A imprensa do período da Independência é uma fonte valiosíssima para se apreender a participação dos diversos atores desse processo político, já que muitas personalidades políticas faziam-se ouvir mediante a publicação de jornais, periódicos e panfletos. Nesse contexto histórico, as folhas impressas, além de funcionarem como porta-vozes de correntes políticas, possuíam um caráter altamente pedagógico, uma vez que se preocupavam em "preparar o povo para a nova era que ali se iniciava" 25 . Muitos eram os verbetes e artigos direcionados a explicar o "fazer política" para seus leitores, seja elucidando conceitos-chave como Constituição e representação, seja informando e analisando os principais acontecimentos políticos do Brasil. Por fim, os periódicos funcionavam como uma "porta aberta", ainda nos dizeres de Lustosa, para que "gente das mais diversas origens e formações" aproveitassem a imprensa para "se lançar na vida pública”, valendo-se da publicação das cartas, anônimas ou não, enviadas pelos leitores.

\footnotetext{
${ }^{21}$ Ibidem, p. 185.

${ }^{22}$ Ibidem, p. 186.

${ }^{23}$ Ibidem, p. 196.

${ }^{24}$ Cf., por exemplo, RIBEIRO, Gladys Sabina; FERREIRA, Tânia Maria Bessone Cruz (orgs.). Linguagens e práticas de cidadania no século XIX. São Paulo: Alameda, 2010; NEVES, Lúcia M. Bastos Pereira das. Corcundas e constitucionais: a cultura política da Independência (1820-1822). Rio de Janeiro: Revan/FAPERJ, 2003; CARVALHO, José Murilo de; NEVES, Lúcia Maria B. Pereira das; BASILE, Marcelo (orgs.). Guerra literária: panfletos da Independência (1820-1823), 4 v. Belo Horizonte: UFMG, 2014.

${ }^{25}$ LUSTOSA, Isabel. “O debate sobre os direitos do cidadão na imprensa da Independência”. In: RIBEIRO, Gladys Sabina; FERREIRA, Tânia Maria Bessone Cruz (orgs.). op. cit., p. 11.
} 
O jogo político modificava-se, surgindo assim novas alianças e novos adversários políticos. É neste momento que o grupo de Ledo aproxima-se do jornalista radical João Soares Lisboa - redator do Correio do Rio de Janeiro, periódico que desde seu primeiro número defendia a convocação de uma Assembleia Legislativa com eleições diretas de seus representantes. A atuação do procurador Gonçalves Ledo será neste sentido, propondo no Conselho que se adote o método direto de votação, afirmando ser esta a vontade do "povo" do Rio de Janeiro, proposta que será combatida pelo poderoso José Bonifácio e seus partidários. Ledo e Soares Lisboa acabam derrotados, não sem antes serem acusados de "republicanos", "democratas", "conspiradores" e "anarquistas". A frágil aliança surgida entre Ledo e Bonifácio em torno da Independência - os liberais fluminenses, ao longo do segundo semestre de 1821, haviam se distanciado dos portugueses por conta dos decretos das Cortes que usurpavam a soberania do Brasil desfazia-se no momento em que Soares Lisboa era processado por "abuso de liberdade de imprensa" e Ledo e seus companheiros eram exilados do Brasil.

Já para o historiador Renato Lopes Leite, o grupo formado por Gonçalves Ledo, Cunha Barbosa, Clemente Pereira e Soares Lisboa deve ser caracterizado como "republicano". O fato de, após o "Fico", terem se rearranjado em torno da autoridade de d. Pedro e professado a defesa de uma "monarquia constitucional representativa" não nega a existência, nem diminui a importância do republicanismo naquele momento. Para este autor, antes da dissolução da Constituinte - o "18 de Brumário brasileiro"26 -, em novembro de 1823, Soares Lisboa, o grupo de Ledo e até frei Caneca eram comedidos e cautelosos na defesa que faziam do republicanismo. Raramente falavam de forma explícita em "república", já que, à época, a palavra guardava um sentido pejorativo, sendo associada à ação de "anarquistas", “carbonários" e desordeiros ${ }^{27}$. Discursavam, isso sim, a favor de um regime constitucional representativo, onde a autoridade tanto do Executivo, quanto do Legislativo estaria limitada pela lei, que por sua vez seria elaborada por representantes eleitos pelo povo.

Após a medida arbitrária que dissolveu a Constituinte ${ }^{28}$, o tom do discurso mudaria, tornando-se mais radical, fazendo uma intransigente defesa de um governo

\footnotetext{
${ }^{26}$ LEITE, Renato Lopes. Republicanos e libertários: pensadores radicais no Rio de Janeiro (1822). Rio de Janeiro: Civilização Brasileira, 2000, p. 37. A expressão é de frei Caneca.

27 Ibidem, p. 33.

${ }^{28}$ No dia 12 de novembro, por volta de uma hora da tarde, chegava à Assembleia o decreto que ordenava a dissolução da mesma. Os deputados, cercados pela tropa, retiraram-se do prédio da Cadeia Velha de forma pacífica. Foram presos ao saírem do plenário os deputados Antonio Carlos, Martim Francisco, Belchior Fernandes Pinheiro, José Joaquim da Rocha Franco e Francisco Gê Acayaba Montesuma. José Bonifácio
} 
republicano ou federativo, cuja luta de maior expressão foi a Confederação do Equador (1824). Nesta, o Imperador seria acusado de déspota e tirânico, e os republicanos denunciariam a tendência absolutista e centralizadora da Constituição outorgada de 1824. Segundo Renato Leite, "apenas em momentos de extrema violência e ruptura do tecido social", como foi a dissolução armada da Constituinte, seguida da prisão de alguns deputados, os republicanos expressariam "publicamente a ideia de república, notadamente com o uso da palavra 'federação' ou 'confederação"”29. "República" passaria, então, a ser entendida como um "contraponto ao governo sem leis e nãoconstitucional da monarquia absolutista" 30 professada por d. Pedro. Porém, isso não significa afirmar que os republicanos não tinham atuado ativamente na cena política até a eclosão da Confederação do Equador. A ideia defendida por Renato Leite é que houve a ação de "republicanos e libertários" já em 1822, envolvidos ativamente nos episódios do "Fico" e da convocação da Assembleia Constituinte.

O autor nos conta que, aos 19 de setembro de 1821, quatro dias após a publicação do primeiro número do Revérbero Constitucional Fluminense, houve um jantar entre os dois redatores daquele jornal, Joaquim Gonçalves Ledo e Januário da Cunha Barbosa, e o deputado eleito às Cortes, Antonio Carlos Ribeiro de Andrada Machado, que se encontrava no Rio de Janeiro a caminho de Lisboa. As testemunhas deste encontro inquiridas em processo contra os redatores do Revérbero -, corroboram com a ideia de que os dois republicanos tentaram convencer aquele deputado a engendrar, junto às Cortes, a partida do príncipe real para Portugal, quer dizer, do "tigrezinho filho de outro grande tigre que já tinha saído do Brasil"31. A expressão "tigrezinho" ou "leãozinho" foi citada por várias testemunhas, referindo-se a d. Pedro, o que é bastante sintomático do apreço daqueles redatores pela república e de sua oposição ao regime monárquico absolutista e ao monarca em questão. Ou seja, também para Renato Leite o grupo de Ledo era, nos bastidores, contrário ao "Fico", inclusive tentou obstar a permanência do regente no país, apelando para o ex-revolucionário de 1817, Antonio Carlos Ribeiro.

\footnotetext{
foi preso em casa, na rua do Catete, e encaminhado à fortaleza de Santa Cruz, onde encontrara os demais deputados e o jornalista e amigo íntimo Vasconcellos de Drummond. Alguns dias depois seriam exilados. Igualmente presos, mas depois libertados, foram os deputados Muniz Tavares, Henriques de Resende, Carneiro da Cunha, Alencar, Cruz Gouveia Xavier de Carvalho e Luís Inácio de Andrade Lima. Segundo José Honório Rodrigues, o ministro dos Negócios e Estrangeiros à época, constituinte Carneiro de Campos, teria se recusado a assinar o ato de dissolução. Sobre o assunto e o ato de dissolução, cf. RODRIGUES, José Honório. A Assembleia Constituinte de 1823. Petrópolis: Editora Vozes, 1974.

${ }^{29}$ LEITE, Renato Lopes. op. cit., p. 54.

${ }^{30}$ Ibidem, p. 37.

${ }^{31}$ Depoimento de Antônio Vieira da Soledade, testemunha no 26 apud LEITE, Renato Lopes. op. cit., p. 74.
} 
Segundo o depoimento do próprio deputado, tratou-se, neste jantar, "sobre a Constituição própria, e organização do Governo do Brasil”. Antonio Carlos afirmou ainda que Ledo e Cunha Barbosa assentavam “que a forma Monárquica era a precisa nas atuais circunstâncias, todavia teoricamente se inclinavam para um governo federal uma vez que as circunstâncias o permitissem". Eximia-se da alcunha de republicano, a qual the era atribuída desde 1817, garantindo às autoridades que havia demonstrado, naquela noite, "a impossibilidade de toda a casta de governo republicano no Brasil, não só pela experiência que tinha do Brasil, como pelos princípios gerais teoréticos”, à qual Ledo e Cunha Barbosa haviam aparentemente anuído. Relatou também que os redatores do Revérbero revelaram "desconfianças sobre a tendência de algumas medidas tomadas por S.M. o Imperador para o estabelecimento do poder absoluto", e ao mesmo tempo algum "desejo de escaparem deste perigo pela remoção de S.M. para Portugal" 32 . Todas as testemunhas do processo, portanto, não desmentiram as "evidências de republicanismo" 33 dos dois acusados e o fato de aspirarem a partida de d. Pedro para Portugal, sem possibilidade de retorno.

A astúcia daqueles indivíduos revela-se quando, apesar de serem contrários à permanência do príncipe no Brasil, constata-se que foi o republicano José Clemente Pereira quem esteve por trás da Representação do povo do Rio de Janeiro pedindo a "ficada neste Reino" do regente, já que, "após muitas reflexões”, utilizando-se do "pretexto pouco airoso de recear ser comprometido [como contrário à causa nacional]" 34 , concluiu pela conveniência de se ter d. Pedro no Brasil, sob a condição de que uma Junta de Governo fosse criada para auxiliá-lo em sua regência. Ledo e Cunha Barbosa, por sua vez, escrevem no Revérbero que "o Brasil adotando o Príncipe, adotou o partido mais seguro; vai gozar dos bens da Liberdade sem as comoções da Democracia, e sem as violências das Arbitrariedades" 35 . Ou seja, na avaliação de Renato Leite, existia "um abismo entre o que a imprensa republicana publica, e a ação concreta e pragmática dos republicanos, entre o que se faz, e o que se diz" ${ }^{36}$. Dessa forma, "a tão proclamada

\footnotetext{
32 Depoimento de Antonio Carlos Ribeiro de Andrada Machado, testemunha $\mathrm{n}^{\mathrm{o}} 63$ apud LEITE, Renato Lopes. op. cit., p. 76-77.

${ }^{33}$ LEITE, Renato Lopes. op. cit., p. 78.

${ }^{34}$ Apud LEITE, Renato Lopes. op. cit., p. 79

${ }^{35}$ Revérbero Constitucional Fluminense, no 11, 22 de janeiro de 1822 apud LEITE, Renato Lopes. op. cit., p. 92.

${ }^{36}$ LEITE, Renato Lopes. op. cit., p. 54.
} 
unanimidade em torno do Fico é uma invenção simbólica do imaginário político da época" 37 , já que não representava os interesses reais dos republicanos naquele momento.

Após o "Fico", o grupo de Ledo teria se rearranjado em torno do príncipe regente e do projeto de uma monarquia constitucional representativa, divorciando-se finalmente das Cortes de Lisboa e pressionando para que um "Congresso Constituinte" brasileiro fosse convocado:

Ao defenderem o retorno do regente Pedro a Portugal, os pensadores do republicanismo provavelmente tinham em mente $o$ ideal de igualdade entre o Brasil e Portugal. Com a permanência do príncipe no Brasil, somente um Congresso Constituinte poderia zelar pela igualdade e autonomia entre Brasil e Portugal, pensam os republicanos. ${ }^{38}$

Desta feita, o grupo de Ledo aproxima-se do jornalista e libertário João Soares Lisboa. Na ótica daquele historiador, essa associação "acabou desencadeando o processo de convocação da Assembleia Constituinte e Legislativa do Brasil" ${ }^{39}$, em razão de terem conseguido, por meio das páginas do Correio do Rio de Janeiro - que aos poucos substituía o Revérbero como porta-voz dos republicanos -, convencer a sociedade e, sobretudo, a maior parte da classe política acerca da importância de um Congresso brasílico. Neste momento, porém, tal posição contrariava a opinião de muitos indivíduos que estavam no poder, como o futuro visconde de Cairu e censor régio, José da Silva Lisboa, e o então ministro José Bonifácio. Ambos se posicionavam contrários à convocação de Cortes. Este último temia o que chamava de "desordens das Assembleias Constituintes" 40 , enquanto Silva Lisboa, "atormentado pelo espectro do Conselho dos Notáveis e dos Estados Gerais Franceses" ${ }^{\text {, }}$, receava que a convocação de Cortes pudesse levar a uma Revolução Francesa no Brasil. É o que se apreende do trecho a seguir, atribuído a ele:

Assim desadoro, clamo, e protesto, contra o projeto anticonstitucional e incendiário, de sedição Popular, e de tremenda responsabilidade, anunciado no Correio [do Rio de Janeiro] e ora corrente pelo Prelo (...) A requerida Assembleia é mera farsa e paródia da que perdeu a França e a Europa, principiando pelo Ajuntamento dos Notáveis, e acabando por

\footnotetext{
${ }^{37}$ Ibidem, p. 51.

38 Ibidem, p. 95.

${ }^{39}$ Ibidem, p. 25.

${ }^{40}$ SOUZA, Octávio Tarquínio de. História dos Fundadores do Império do Brasil, vol. 1 (A vida de José Bonifácio), 2a ed. Rio de Janeiro: José Olympio, 1957, p. 195.

${ }^{41}$ LEITE, Renato Lopes. op. cit., p. 21.
} 
Governo Despótico Militar do Tirano Corso, depois de passar o Corpo Legislativo por tantas horrendas fases de Assembleia Nacional. ${ }^{42}$

De forma semelhante ao que havia acontecido no início do ano com o "Fico", aos 18 de maio de 1822, o Correio do Rio de Janeiro convocava os cidadãos fluminenses a irem à Tipografia Silva Porto, local onde o jornal era impresso, para assinarem uma Representação elaborada por Gonçalves Ledo, Cunha Barbosa, Soares Lisboa e Clemente Pereira. Essa espécie de "petição" pedia a convocação de "Cortes Brasilianas" com no mínimo 100 deputados, a terem lugar na "sede da Soberania do Brasil" (Rio de Janeiro), e cujas sessões deveriam ser públicas. Essa "Assembleia Geral Representativa" exerceria o poder Legislativo, emendando, alterando e reformando a Constituição elaborada pelas Cortes de Lisboa, e promoveria a união com Portugal ${ }^{43}$. Havia ainda uma solicitação mais polêmica: que as eleições se dessem de forma direta. Em sessão do Conselho de Procuradores aos 10 de junho, Ledo defenderia essa proposta - segundo ele a preferida pela "opinião pública" - que, contudo, não sairia vitoriosa. Os republicanos, todavia, já haviam conseguido uma importante vitória - a convocação de uma Assembleia Legislativa e Constituinte -, revelando sua atividade e força política no período anterior à Confederação do Equador:

Tudo leva a crer que a ação dos personagens do republicanismo (...) e a pressão da imprensa republicana induziram/forçaram os dirigentes do Estado brasileiro a renderem-se à exigência de convocação de uma Constituinte no Brasil ${ }^{44}$.

Quanto à posição daqueles aos quais a historiografia convencionou chamar de “adversários políticos do grupo de Ledo", Emília Viotti é talvez quem mais precisamente dimensione suas posições políticas. Buscando mostrar a construção do "homem e mito" José Bonifácio, destacaria as diferentes visões que os contemporâneas e a própria historiografia lançaram sobre o velho Andrada. Ainda em 1822, várias foram as imagens forjadas acerca de José Bonifácio, tido por muitos como "timoneiro da Independência", "Pai da Pátria" e "Patriarca" do Brasil, e, por outros, como "ministro dos menos liberais: arbitrário, vaidoso, discricionário" ${ }^{45}$.

\footnotetext{
${ }^{42}$ Reclamação do Brasil Parte XIV apud LEITE, Renato Lopes. op. cit., p. 21.

${ }^{43}$ LEITE, Renato Lopes. op. cit., p. 125-126.

${ }^{44}$ Ibidem, p. 159.

${ }^{45}$ COSTA, Emília Viotti da. “José Bonifácio: homem e mito”. In: MOTA, Carlos Guilherme (org.). 1822: dimensões. São Paulo: Perspectiva, 1972, p. 106.
} 
Pouco após a Independência, desentendimentos com d. Pedro forçaram o ministro a pedir demissão, de forma que "apareceram várias representações e panfletos pleiteando sua recondução" ao cargo, assegurando ser ele "a única âncora (junto ao Trono) do novo Império"46. Parte da imprensa fazia coro às representações populares, como é o caso do jornal O Tamoio, editado pelo amigo íntimo dos Andradas, Vasconcellos de Drummond. Em um de seus editoriais, afirmou-se que José Bonifácio fora o primeiro a "trovejar contra a perfídia das Cortes portuguesas, (...) a pregar a Independência e a liberdade do Brasil”, enfrentando tanto "representantes do partido lusitano", quanto "democratas republicanos que se aliavam no intuito de mandar de volta a Portugal o príncipe regente" ${ }^{47}$. Em um artigo publicado no Diário do Rio de Janeiro, em 18 de março de 1835, José da Silva Lisboa, o visconde de Cairu, exaltava o "Patriarca da Independência", para quem, dizia ele, "a História imparcial resguardará o título de Salvador do Brasil pelos conselhos dados a d. Pedro I, o Salvador do Império Constitucional da América"48. Assim, criava-se o mito, muito explorado pela historiografia brasileira, de que a Independência seria um "fruto da ação deliberada de d. Pedro e José Bonifácio"49.

Contudo, não faltaram na época inimigos políticos que forjaram o que a autora chamou de "lenda negra" sobre José Bonifácio. Diatribes contra o ministro e sua política apareciam com frequência no Correio do Rio de Janeiro, no Revérbero Constitucional Fluminense e no Malagueta, que reprovavam suas "atitudes aristocráticas, sua aversão à representação popular e a oposição que fazia à convocação de uma Constituinte" Comentava-se que somente diante da pressão popular José Bonifácio cedera e convocara uma Assembleia nacional, que pretendia manter o Brasil unido à Portugal a qualquer custo e que perseguia os elementos mais liberais, desejosos de ampliar as liberdades civis. A “versão antiandradina" encontrou acolhida posteriormente na historiografia, como na obra do historiador clássico Francisco Adolfo de Varnhagen, matriz dessa construção discursiva que apresentou o ministro como "um personagem vingativo e arbitrário, minimizando sua participação política no país" ${ }^{51}$. Construção cuja continuidade observa-

\footnotetext{
${ }^{46}$ Ibidem, p. 104.

${ }^{47}$ Ibidem, p. 105.

${ }^{48}$ Apud COSTA, Emília Viotti da. “José Bonifácio...”. op. cit., p. 105.

${ }^{49}$ COSTA, Emília Viotti da. “José Bonifácio...”. op. cit., p. 105.

${ }^{50}$ Ibidem, p. 106.

${ }^{51}$ Ibidem, p. 107.
} 
se na obra de Francisco Assis Cintra, para o qual José Bonifácio seria o "pseudo-patriarca da Independência", um político "caviloso, violento, cruel, maquiavélico"52.

Ao ressaltar que as lendas andradinas forjaram-se "no calor dos acontecimentos, fruto das perspectivas contraditórias dos participantes", Emília Viotti propõe uma "análise das condições estruturais" do período da Independência, capaz de "ultrapassar os limites da crônica subjetiva" para assim poder redefinir objetivamente "o papel real de José Bonifácio"53 na emancipação do Brasil. Após uma breve análise da educação ilustrada que recebera em Coimbra - ponto que também será crucial para as análises de José Murilo de Carvalho e Lúcia Neves -, a autora destaca que José Bonifácio - que havia passado brevemente pela França de 1791, "guardando uma penosa impressão dos movimentos revolucionários e da agitação das massas" - seria "um liberal, mas nunca um democrata" ${ }^{, 54}$. Quando enfim voltou ao Brasil e assumiu como ministro de d. Pedro, logo após seu protagonismo na Junta de São Paulo, a situação é bastante crítica; três grupos disputavam a liderança dos acontecimentos naquele momento.

O primeiro deles, formado em sua maioria por comerciantes portugueses ansiosos em restabelecer os antigos privilégios, concentrados, em sua maioria, no Rio de Janeiro e em cidades portuárias do Norte e Nordeste, aos quais se juntavam militares e alguns funcionários da Coroa, estavam decididos a apoiar a política das Cortes de Lisboa. O segundo grupo, composto de brasileiros e portugueses recrutados entre os elementos mais poderosos em posses e empregos de representação, como altos funcionários, fazendeiros e comerciantes ligados ao mercado externo, almejava a autonomia do país, embora encarasse com simpatia a fórmula da monarquia dual; diante da impossibilidade dessa solução, aceitaram a ruptura definitiva com Portugal. Finalmente, um terceiro grupo, composto de elementos mais radicais e democratas, em sua maioria ligados a atividades urbanas e setores médios da sociedade, sonhava com um regime republicano à semelhança do que acontecia na América hispânica. Esse último grupo "viu-se enfraquecido a partir do momento em que se ofereceu a possibilidade de realização da Independência sob a direção do príncipe", não sendo poucos os que, como o irmão de José Bonifácio e ex-revolucionário de 1817, Antonio Carlos, sentiram-se “à vontade para

\footnotetext{
${ }^{52}$ CINTRA, Francisco Assis. O homem da Independência: história documentada de José Bonifácio, do seu pseudo-patriarcado e da política do Brasil em 1822. São Paulo: Companhia Melhoramentos, 1921, p. 33.

${ }_{53}^{53}$ COSTA, Emília Viotti da. “José Bonifácio...”. op. cit., p. 107.

${ }^{54}$ Ibidem, p. 112, grifo nosso.
} 
adotar em 1822 a solução monárquica, que oferecia a garantia de uma revolução de cima para baixo, dispensando grande mobilização popular" ${ }^{\circ 5}$.

Em um primeiro momento, o ministro aproximar-se-ia do "partido monarquista", aliando-se aos grandes proprietários de terra e altos funcionários, haja vista o "horror que votava às revoluções de massa, ao que considerava excessos de liberdade" e a sua "antipatia invencível pelas soluções democráticas" ${ }^{56}$. Tal posição reflete-se em sua defesa de eleições indiretas para a Constituinte e sua obstinação em reprimir as agitações perturbadoras da ordem pública, como aquelas causadas pelos democratas. Tratava-se, porém, de uma "aliança precária", já que José Bonifácio se posicionava a favor da emancipação gradual dos escravos, o que ia de encontro aos interesses dos grandes proprietários que então apoiava. A atitude ameaçadora das Cortes, por sua vez, aproximou o ministro dos grupos mais radicais, de forma que "todos se uniram em torno de José Bonifácio e do príncipe contra o inimigo comum", resultando na Independência do Brasil.

Garantida a emancipação do país, suas frágeis alianças se desfizeram porque, segundo a referida historiadora, o velho Andrada aplicara-se com energia na tarefa de

$$
\begin{aligned}
& \text { reprimir tanto as agitações promovidas pelos elementos do } \\
& \text { "partido português" - "pés de chumbo" e "corcundas" como os } \\
& \text { chamava -, elementos contrários ao príncipe e à causa da } \\
& \text { Independência, quanto as reivindicações dos liberais que } \\
& \text { ultrapassavam os limites que lhe pareciam corretos: os } \\
& \text { "demagogos", "anarquistas", aqueles que mais tarde na } \\
& \text { Assembleia Constituinte chamaria de "mentecaptos } \\
& \text { revolucionários". Aumentou o número de espias na política, } \\
& \text { mandou vigiar casas, apreender panfletos, prender jornalistas } \\
& \text { (...). Tais medidas antagonizaram-no mais ainda com os setores } \\
& \text { radicais que passaram abertamente à oposição, castigando-o pela } \\
& \text { imprensa, disputando-lhe a simpatia do príncipe, intrigando-o } \\
& \text { sempre que possível. }{ }^{57}
\end{aligned}
$$

Os adeptos de um liberalismo mais radical, como Gonçalves Ledo, passam a se reunir em torno da loja maçônica Grande Oriente, agraciando d. Pedro com o título de Grão-Mestre, antes pertencente a José Bonifácio. Este, por sua vez, “desconfiado do radicalismo dos membros do Grande Oriente" 58 , funda a sociedade secreta Apostolado, cujos membros obedeciam à linha política do ministro de frear as reivindicações mais liberais e radicais do momento: juravam fidelidade ao Império constitucional,

\footnotetext{
55 Ibidem, p. 122-123.

${ }^{56}$ Ibidem, p. 123.

${ }^{57}$ Ibidem, p. 128.

${ }^{58}$ Ibidem, p. 130.
} 
comprometendo-se a fazer oposição "tanto ao despotismo que o altera, quanto à anarquia que o dissolve" $" 59$. O ministro consegue ordenar o fechamento da loja maçônica dos radicais e a deportação do jornalista João Soares Lisboa por abuso de liberdade de imprensa. Ledo, porém, contando com o apoio de José Clemente Pereira, presidente do Senado da Câmara do Rio de Janeiro, manobra no sentido de conferir a d. Pedro o título de Defensor Perpétuo do Brasil e consegue reabrir o Grande Oriente e reverter a ordem de deportação do redator do Correio do Rio de Janeiro. Sentindo-se desprestigiado, José Bonifácio apresenta sua demissão, sendo acompanhado por seu irmão Martim Francisco, à época ministro da Fazenda.

Os membros do Apostolado e partidários dos Andradas empreendem forte campanha a favor da reintegração dos ministros, levando parte da população do Rio de Janeiro a apoiar os manifestos e representações espalhados pelas ruas da cidade. Os demissionários são apresentados como 'vítimas da conspiração dos radicais, inimigos do trono". Ainda segundo a autora, "não faltou quem na época qualificasse o grupo de Ledo de democrata" ${ }^{\circ 0}$, embora isso não fosse verdade:

\begin{abstract}
A oposição que o grupo de Ledo fazia à monarquia não era tão fundamental. Visava apenas cercear o poder real e submetê-lo ao parlamento. Tanto é assim que, mais tarde, acomodaram-se à ordem monárquica. Durante a Regência, outros grupos mais radicais passaram a fazer-lhes oposição, em nome de um liberalismo mais democrático, criticando o latifúndio, o trabalho escravo, a aristocracia e os privilégios. ${ }^{61}$
\end{abstract}

Reintegrado ao ministério, sentindo-se apoiado por d. Pedro e por uma parcela da sociedade fluminense, que se manifestara ruidosamente a seu favor, José Bonifácio investiu novamente contra os liberais radicais, efetuando prisões, devassas e penas de exílio para José Clemente Pereira, Januário da Cunha Barbosa e Gonçalves Ledo, "furiosos demagogos e anarquistas". Desta feita, rompia publicamente com os radicais, apoiando-se mais uma vez nos membros do Apostolado. Porém, essa aliança também duraria pouco. Segundo Emília Viotti, tendo vivido mais de trinta anos na Europa, José Bonifácio identificar-se-ia com vários princípios da Ilustração, assimilando "a visão crítica da burguesia europeia, condenando o latifúndio improdutivo, o trabalho escravo", além de sua aversão aos privilégios e títulos de nobreza e a crença na educação, inclusive

\footnotetext{
${ }^{59}$ Ibidem, p. 131.

${ }^{60}$ Ibidem, p. 132.

${ }^{61}$ Ibidem, p. 133.
} 
feminina. Todavia, não apoiaria "soluções revolucionárias, encarando com desconfiança o que considerava "excessos liberdade". Para ele, o chefe de Executivo "devia menos ser um líder revolucionário, um representante do povo do que um déspota esclarecido, e menos um déspota esclarecido do que um monarca constitucional" ${ }^{62}$. Ou seja, ao mesmo tempo em que abominava os excessos da república, não desejava tampouco um governo absolutista. Significativamente, opôs-se "em 1823 ao Imperador como se opusera às intenções republicanas de Ledo e Januário da Cunha Barbosa"63, já que passara a considerar as atitudes de d. Pedro despóticas. Curioso notar que, neste momento, partilharia das mesmas críticas dos radicais que tanto perseguira, aproximando-se deles, sem, contudo, aderir à Confederação do Equador.

Adepto da liberdade, fruto das luzes do século, José Bonifácio, porém, "não avançaria muito no seu liberalismo, cujo limite era dado pelas reivindicações da 'suja e caótica democracia', como dizia" ${ }^{64}$. Talvez a frase que melhor defina sua posição política - porque seu programa político mostra-se mais conservador do que seu programa social - , seja a seguinte:

\footnotetext{
Nas reformas deve haver muita prudência, se conhecer o verdadeiro estado dos tempos, o que estes sofrem que se reforme, e o que deve ficar do antigo. Nada se deve fazer aos saltos, mas tudo por graus, como obra da Natureza. ${ }^{65}$
}

José Honório Rodrigues, por sua vez, analisa a Independência do Brasil como uma revolução que, como sempre, "trazia consigo os germes da contra-revolução"66, de forma que as "ideologias" imperantes no momento - o liberalismo, o conservadorismo e o radicalismo - avançavam e recuavam, disputando entre si a primazia ou o predomínio entre as elites políticas. Essas ideologias organizar-se-iam em quatro facções, "que eram grupos pré-partidários" ${ }^{\prime 67}$ : os liberais, os conservadores, os absolutistas e os radicais. A primeira facção, oriunda do liberalismo vitorioso da Revolução do Porto de 1820, tinha uma tonalidade conservadora. "Isso significa que era moderado no pensamento político,

\footnotetext{
${ }^{62}$ Ibidem, p. 134.

${ }^{63}$ Ibidem, p. 135.

${ }^{64}$ Ibidem, p. 136.

${ }^{65}$ Apud COSTA, Emília Viotti da. “José Bonifácio...”. op. cit., p. 136.

${ }^{66}$ RODRIGUES, José Honório. Independência: revolução e contra-revolução. A evolução política. v. 1. Rio de Janeiro: Francisco Alves, 1975, p. 1.

${ }^{67}$ Ibidem, p. 10.
} 
que não queria destruir a monarquia, nem queria implantar o republicanismo"68, mas apenas reformar o que fosse possível reformar, respeitando as estruturas tradicionais.

\begin{abstract}
Para isso, a primeira missão era destruir a monarquia absoluta, o absolutismo e os mitos que o acompanhavam, como a crença na origem divina dos reis e na legitimidade da continuidade real. Para o liberalismo moderado - que foi o português e o brasileiro - o rei é apenas um elemento do Estado, com uma função determinada e relevante. Para limitar a sua autoridade e estabelecer legalmente sua função, era necessária uma Constituição escrita, que definisse também toda a organização estatal, os poderes e os direitos e deveres do rei e do povo. ${ }^{69}$
\end{abstract}

Segundo aquele historiador, no Brasil, a princípio, o liberalismo apresentou-se dividido em duas tendências, uma mais moderada, e outra "um pouco mais avançada". Ambas começaram sustentando a união, desde que assegurada a autonomia executiva e legislativa, mas depois passaram a defender a Independência. O príncipe, por sua vez, jamais fora um liberal, apenas "serviu-se dos liberais para atingir seus objetivos, assim com os liberais se serviram dele para alcançar seus fins" ${ }^{\circ 0}$, desmascarando-se em novembro de 1823 com a dissolução da Constituinte - duro golpe para o liberalismo, que só ressurgiria com a reabertura do Parlamento, em 1826, e com a queda de d. Pedro I, em 1831.

Tanto Rodrigues como Emília Viotti compartilham da ideia de que se tratava de um liberalismo limitado, sendo seu maior limite a convivência com a escravidão. Esta "falta de consciência social" caracterizou os liberais brasileiros, que professavam

um liberalismo o menos liberal possível, entendido que isso significava que as liberdades e garantias que constituíam sua essência atingiam o grupo social mais selecionado possível e não se estendiam às camadas mais populares. ${ }^{71}$

Já a facção dos conservadores era composta por elementos da classe dominante, ligados à grande propriedade, à riqueza, à defesa do status quo e de privilégios. Posicionam-se como contrários às mudanças e às revoluções que rompem a continuidade entre passado e presente, trazendo grandes riscos às posições econômicas e políticas que ocupavam. Segundo aquele historiador, os conservadores não queriam a contra-

\footnotetext{
${ }^{68}$ Ibidem, p. 31.

${ }^{69}$ Ibidem, p. 32.

${ }^{70}$ Ibidem, p. 36.

${ }^{71}$ Ibidem, p. 40.
} 
revolução, almejando apenas "a manutenção das estruturas essenciais" "72, aceitando mudanças somente no que fosse indispensável, e ainda assim de forma gradual. Aos poucos passaram a aceitar e defender a monarquia constitucional, opondo-se aos absolutistas e tradicionalistas. Estes sim empreenderam a "contra-revolução" brasileira, reagindo à ação dos liberais que levou à Independência do Brasil.

Os absolutistas, contra-revolucionários ou tradicionalistas opunham-se a qualquer liberalismo. Diferentemente dos conservadores, defendiam o estado atual de coisas e, quando perturbado, tratavam de refazê-lo, obstando a realização de mudanças, ainda que gradativas. Defendiam governos autoritários, invocando as origens divinas do poder, acreditando que somente os reis possuíam a soberania, a qual não deveria ser partilhada. Não admitiam a separação dos poderes, considerada uma "heresia liberal"73, e só aceitavam a convocação de Cortes consultivas, jamais deliberativas.

No extremo oposto, encontravam-se os radicais, republicanos ou democratas. $\mathrm{O}$ republicanismo vinha sendo fermentado no Brasil desde a Conjuração Mineira de 1789, mas devido à grande repressão e perseguição do governo, seus partidários mantinham-se cautelosos e discretos. Graças aos escritos da época, a historiografia tendeu a "encaixar" nessa corrente de pensamento homens como Gonçalves Ledo, Januário da Cunha Barbosa e José Clemente Pereira. Porém, para José Honório Rodrigues, esses "não eram os verdadeiros republicanos", eram apenas "liberais radicais". O fato de defenderem a doutrina da soberania popular os caracterizava como liberais, embora isso os aproximasse dos republicanos e democratas. Havia uma grande mobilidade entre os liberais, que ora podiam "ficar mais à direita e aceitar as conciliações que José Bonifácio propunha para se atingir a Independência", ora caminhavam "mais para a esquerda, aliando-se aos extremados" ${ }^{\prime 74}$. Os exemplos mais visíveis de liberais que tomaram o rumo do radicalismo foram Cipriano Barata e Joaquim do Amor Divino Caneca, o frei Caneca, para os quais a soberania residiria no povo, e não no Imperador.

José Honório Rodrigues deixa em evidência a linha tênue que separava as "facções" políticas daquele momento, demonstrando que muitos personagens transitavam livremente entre elas, ao sabor da agenda política. Isso fica claro quando afirma, por exemplo, que frei Caneca seria "o representante mais esclarecido de um liberalismo

\footnotetext{
${ }^{72}$ Ibidem, p. 41.

73 Ibidem, p. 47.

${ }^{74}$ Ibidem, p. 50.
} 
radical, ou radicalismo nacional"75, ou quando considera José Bonifácio um “conservador sensível às reformas" que havia caminhado "para um liberalismo constitucional, ou melhor, para um monarquismo constitucional, ao contrário de seus adversários, que seguiram rotas radicais ou extremadas"76. Ao falar de José da Silva Lisboa, futuro visconde de Cairu, o autor destaca seu liberalismo econômico, ancorado nas ideias de Adam Smith, ao mesmo tempo em que pontua seu conservadorismo político, inspirado em Edmund Burke. Silva Lisboa defenderia "uma liberdade ligada à ordem, não podendo existir sem ela", sendo este um princípio "extremado na carreira da Silva Lisboa, e moderado na de José Bonifácio"77. Nesse sentido, as elites políticas que pleiteavam o poder no momento da Independência flutuavam entre três facções, ora sensíveis a agendas mais liberais, ora mais conservadoras, alguns chegando ao extremo de se posicionarem de forma radical e democrática em relação ao projeto político para o país.

Ao caracterizar os atores do processo político da Independência Lúcia Neves divide a elite política e intelectual em dois grupos: a elite coimbrã e a elite brasiliense. A primeira constituir-se-ia de nomes que compunham, preferencialmente, a elite política, ocupando altos cargos e funções no governo, além de partilharem uma cultura política ilustrada devido aos estudos na Universidade de Coimbra. Contava com um número expressivo de advogados e assumia uma postura de "crítica em face da estrutura do poder estabelecido, o Antigo Regime, sem traduzir, porém, sua proposta de uma ordem nova por meios revolucionários", acreditando em "um ideal reformista de cunho pedagógico, compatível com as Luzes portuguesas". Buscavam a consolidação do Império lusobrasileiro, embora tenham aceitado, em meados de 1822, a opção da monarquia dual, pois "significava a única maneira de continuarem ligados à civilização ilustrada europeia"78. Entre os membros deste grupo distinguiam-se os irmãos Andrada - José Bonifácio, Antonio Carlos e Martim Francisco -, Hipólito José da Costa, Estevão Ribeiro de Rezende, José da Silva Lisboa, Nicolau dos Campos Vergueiro, entre outros.

Já a elite brasiliense provinha, sobretudo, de famílias sem grande poder aquisitivo, setores médios e urbanos. Compunham-se principalmente de sacerdotes, bem como de funcionários públicos sem cargos de maior projeção e de professores. Em sua maioria, estudaram no Brasil, tendo acesso à Ilustração por meio da leitura de livros proibidos e

\footnotetext{
75 Ibidem, p. 51.

76 Ibidem, p. 37.

${ }^{77}$ Ibidem, p. 4.

${ }^{78}$ NEVES, Lúcia M. Bastos Pereira das. op. cit., p. 84.
} 
censurados. "Aceitavam a monarquia, porém, desejavam um rei antes de tudo um cidadão respeitador da soberania popular, ou seja, uma monarquia que fosse a melhor das repúblicas". Preocupados com a soberania do Brasil, defendiam as ideias liberais ainda que essas sacrificassem a unidade do Reino Unido: "nesse sentido, transformaram-se nos ideólogos da Independência do Brasil" ${ }^{\text {79 }}$. Os maiores destaques deste grupo são Joaquim Gonçalves Ledo, Januário da Cunha Barbosa, José Clemente Pereira, João Soares Lisboa, frei Joaquim do Amor Divino Caneca, Luís Augusto May, Cipriano José Barata, José Martiniano de Alencar, Diogo Antônio Feijó, Francisco Muniz Tavares e Francisco Gomes Brandão Montesuma, transformado em Francisco Gê Acayaba de Montesuma.

Foi a elite brasiliense, "sentindo-se a senhora da situação", quem arquitetara tanto o "Fico", quanto a Independência - solução evitada até então pela elite coimbrã -, e ainda pressionara para a convocação "de uma assembleia verdadeira", impondo "suas concepções mais democráticas" e sugerindo a substituição do Conselho de Procuradores, "esse Conselho de Estado disfarçado, "cheirando a Antigo Regime"" 80 por uma Assembleia Legislativa do Império do Brasil. Por fim, conseguiriam convencer o príncipe e a elite coimbrã da necessidade da Independência e da convocação de Cortes brasílicas. Porém, sua rápida ascensão ao poder acabaria após disputas com o grupo coimbrão pelo protagonismo político.

Por sua vez, a elite coimbrã articulou-se em torno do Apostolado, já que pretendia “deter os arroubos democráticos do grupo brasiliense. Se não havia mais como evitar a separação do Brasil", devido à intransigência das Cortes, "era necessário mantê-lo monárquico e católico, submisso às ordens de um rei constitucional": daí a inclinação mais "conservadora" dos membros dessa sociedade secreta. Em 1823, frei Caneca compararia o Apostolado a um "clube de aristocratas servis" que até no "santuário" da Assembleia Constituinte haviam penetrado. Desta feita, os dois grupos - o coimbrão e o brasiliense - disputavam "algum espaço público em que pudessem não só elaborar um discurso político, mas também atuar nas decisões da construção do Império brasileiro" $"$.

Segundo Lúcia Neves, apesar de as duas elites do contexto da Independência concordarem quanto à solução monárquica constitucional - nem mesmo os setores mais radicais da elite brasiliense cogitavam a possibilidade de um governo republicano em tão

\footnotetext{
${ }^{79}$ Ibidem, p. 85.

${ }^{80}$ Ibidem, p. 342.

${ }^{81}$ Idem.
} 
vasto território ${ }^{82}$-, abriu-se um "profundo abismo" entre estes dois segmentos logo após a separação formal do Brasil. As divergências acirraram-se quando o grupo de Ledo tentou impor a d. Pedro um "juramento prévio de guardar, manter e defender a Constituição" que seria elaborada pela Assembleia Constituinte, a ser pronunciado no dia de sua aclamação (12 de outubro), à semelhança do que acontecera em Portugal. A proposta era desagradável não só para o grupo coimbrão como para o próprio regente, "que já se rebelara contra o despotismo das Cortes [de Lisboa] ao considerar seu pai prisioneiro desse faccioso organismo". Além do mais, o grupo de Ledo insistia na noção de soberania popular, reforçando a ideia de que a aclamação seria uma delegação da "vontade universal de todo o povo brasileiro" 83 , e não uma condição natural e hereditária.

A "reação" às vitórias da elite brasiliense veio rapidamente. Um dia depois da aclamação, baixou-se decreto que determinava a fórmula que deveria principiar todos os atos do governo, que seriam assinados por "d. Pedro, pela graça de Deus e unânime aclamação dos povos, Imperador Constitucional e Defensor Perpétuo do Brasil”. Segundo Lúcia Neves, "roubava-se ao povo o direito soberano de ter aclamado seu Imperador. Voltava-se aos usos antigos, em que o monarca retirava seu poder de Deus e, em segundo lugar, dos homens" ${ }^{\text {"84. Aos }} 20$ de outubro de 1822, João Soares Lisboa - que havia escrito no Correio do Rio de Janeiro que se "os povos manifestarem geral desejo de serem republicanos, não encontrarão em mim oposição, antes farei quanto puder para que o consigam" ${ }^{85}$-, viu a circulação de seu jornal ser suspensa. José Bonifácio passou a empreender forte campanha contra o grupo brasiliense, o qual foi taxado de anarquista, democrático e republicano. Aos 2 de novembro, o Imperador e seu ministro autorizaram uma devassa contra os "facciosos e perturbadores" da opinião pública, acarretando a deportação dos principais elementos da elite brasiliense - Ledo, Cunha Barbosa, Soares Lisboa e Clemente Pereira -, que sequer puderam se defender, já que os principais veículos de suas ideias, o Revérbero e o Correio do Rio de Janeiro, encontravam-se fora de circulação por ordens de José Bonifácio.

Em $1^{\circ}$ de dezembro, d. Pedro seria coroado Imperador do Brasil, "através de uma cerimônia digna das monarquias europeias do Antigo Regime. Eram passos para situar o Brasil na tradição do absolutismo ilustrado", professado pelo Imperador, afinado com os

\footnotetext{
${ }^{82}$ Ibidem, p. 377.

${ }^{83}$ Ibidem, p. 388.

${ }^{84}$ Ibidem, p. 395.

${ }^{85}$ Apud NEVES, Lúcia M. Bastos Pereira das. op. cit., p. 395.
} 
interesses da elite coimbrã. Tratava-se de um evento bem diverso do que havia sido a aclamação, até porque "restringia bastante a participação ativa de alguns segmentos" 86 mais populares e revestia-se de muito luxo e pompa. $\mathrm{O}$ juramento do Imperador à Constituição era condicional, já que somente a aceitaria se essa fosse "digna do Brasil e digna de seu Imortal Defensor como a pedem os votos dos verdadeiros amigos da Pátria" 87 - a fórmula repetir-se-ia em sua "Fala do Trono" proferida por ocasião da instalação dos trabalhos da Assembleia Constituinte, em 3 de maio do ano seguinte. Desta feita, d. Pedro colocava-se na qualidade de "juiz e revisor da Constituição" que viria a ser elaborada pelos representantes da nação, ideia que era contrária àquela defendida pelos membros da elite brasiliense, para os quais a Assembleia Constituinte sobrepunha-se ao Imperador, justamente por conter os representantes legitimamente eleitos pelo povo brasileiro.

Nesse sentido, o Império brasileiro afastava-se por completo da opção democrática, consolidando-se como uma monarquia constitucional "nos moldes daquelas que a Europa da Restauração conhecia desde 1815”. Daí em diante, os acontecimentos internacionais, especialmente o retorno do absolutismo em Portugal, com a vitória da Vila Francada, em 1823, "serviram de estímulo a d. Pedro para revelar as facetas mais autoritárias de seu caráter”. O Imperador deixava claro que aceitava uma Constituição, mas jamais admitiria "converter-se em um mero instrumento nas mãos dos representantes da nação" ${ }^{\$ 8}$, o que ao longo de 1823 o oporia a membros da própria elite coimbrã, notadamente aos irmãos Andrada.

\section{Os espectros políticos dos atores da Constituinte de 1823}

O fato de os autores e autoras anteriormente citados divergiram quantos aos grupos, partidos ou facções existentes à época da Independência aponta-nos para a volatilidade das alternativas de futuro e dos projetos políticos que se apresentavam naquele contexto histórico. Desta feita, a definição e composição exata desses grupos, partidos ou facções tornam-se muito difíceis. Contudo, diante do exposto, é possível delinear os espectros políticos pelos quais transitavam os membros das elites políticas da época. Como já afirmamos, um mesmo ator político poderia ser revolucionário e

\footnotetext{
${ }^{86}$ NEVES, Lúcia M. Bastos Pereira das. op. cit., p. 411.

${ }^{87}$ Apud NEVES, Lúcia M. Bastos Pereira das. op. cit., p. 409.

${ }^{88}$ NEVES, Lúcia M. Bastos Pereira das. op. cit., p. 411.
} 
republicano em 1817, monarquista constitucional e ferrenho defensor do poder real em 1822 e, em fins de 1823, apresentar-se favorável à supremacia do Legislativo sobre o Executivo.

Os espectros políticos, balizas dos comportamentos políticos da elite, podem ser definidos em dois níveis. No primeiro nível - e isso fica mais evidente na crise dos anos 1820 -, os espectros dividiam-se em dois universos mentais: entre os defensores do absolutismo, ou seja, da conservação irrestrita das prerrogativas reais, e os de orientação mais liberal, que já haviam embarcado na "locomotiva das transformações estruturantes" do século XIX. Entre os primeiros incluíam-se, por exemplo, os ministros e conselheiros de d. João, Tomás Antônio de Vilanova Portugal, Pedro de Sousa e Holstein, o conde de Palmela, e Silvestre Pinheiro Ferreira. Seus conselhos ao rei iam desde a intervenção militar da Santa Aliança até à concessão de uma Carta Constitucional que sanasse as inquietações vintistas e assegurasse plenos poderes ao soberano, inclusive sobre o poder Legislativo. Em comum, viam com desconfiança o constitucionalismo e os ideais regeneradores defendidos pelos liberais.

Por sua vez, os elementos que abraçaram uma orientação liberal estavam ansiosos por partilhar a soberania da nação entre o rei e os representantes do poder Legislativo, inaugurando um novo pacto social firmado em Carta Constitucional. O rei que se recusasse a abrir mão de parcela de sua soberania estaria agindo como um déspota, bem como os ministros que o aconselhassem nesse sentido. Incluíam-se nesse espectro os liberais vintistas e, posteriormente, a maioria das elites políticas do Brasil, unidas finalmente em torno de um consenso quanto à monarquia constitucional como o melhor arranjo para o país. A opção liberal e constitucionalista vai se delineando a partir da Revolução de 1820, quando os liberais do Porto proclamaram a regeneração do Império Português de tal forma que abarcasse todas as partes do vasto Império, evocando a união entre as "nações irmãs" e a participação dos "portugueses d'além-mar". Desta forma, as elites políticas do Brasil, submersas nas transformações que se processavam entre o final do século XVIII e o início do XIX, acataram ao chamado do Douro e apoiaram o coro por "Cortes e Constituição". O triunfo do liberalismo, portanto, se dava por meio de um instrumento, a Constituição, que "exprimia o anseio político de todos os membros das elites política e intelectual, tanto do Brasil, quanto de Portugal" ${ }^{\prime 9}$, como fica claro nas instruções para as eleições às Cortes de Lisboa:

\footnotetext{
${ }^{89}$ Ibidem, p. 148.
} 
Que nos resta, pois, a fazer para complementar o majestoso edifício da nossa Regeneração? O mais espinhoso, sem dúvida, a reunião dos sábios, que formando um Congresso iluminado organize a mais depurada Constituição em que se firme para sempre a segurança pessoal e de liberdade..$^{90}$

Em 1820, quando, finalmente, d. João VI se vê obrigado a satisfazer às ordens do Soberano Congresso de Lisboa e decide retornar a Portugal, juntamente com sua comitiva "reacionária" - para se usar a expressão de Caio Prado Júnior -, o liberalismo consegue sua primeira, e simbólica, vitória. A partir daquele momento, não será mais possível uma configuração política típica de Antigo Regime ${ }^{91}$, justamente por conta desse deslocamento da ideia de soberania. Keith Michael Baker, em verbete para o Dicionário Crítico da Revolução Francesa, descreve esse novo pacto social, no qual

a soberania era considerada ao mesmo tempo algo que emanava do corpo da nação; seu exercício era conferido por contrato mútuo entre o rei e a nação a um monarca, que o exercia submetendo-se às prescrições desse contrato, o qual incluía o princípio de consentimento à legislação, podendo o monarca ser denunciado pela nação, caso não respeitasse os termos desse contrato. Essa concepção essencialmente negativa, defensiva, da soberania da nação ia, infalivelmente, deslocar o locus da identidade política (e, portanto, da soberania) do rei para a nação. ${ }^{92}$

Assim, no início do Oitocentos, a monarquia constitucional passou a ser a "única saída" para as monarquias absolutas. Era o triunfo do liberalismo - ao menos do liberalismo constitucionalista. Ao longo dos primeiros anos do Brasil enquanto nação independente, as elites políticas professariam essa doutrina de forma mais ou menos avançada. Vale ressaltar, porém, como já foi assinalado por diversos historiadores, que esse liberalismo, fruto das "mitigadas Luzes portuguesas", possuía alguns limites que o tornavam, à primeira vista, paradoxal. $\mathrm{O}$ fato de conviver com a escravidão e manter uma

\footnotetext{
${ }^{90}$ Instruções para a inteligência dos Povos nas próximas eleições de Eleitores e Deputados de Cortes apud NEVES, Lúcia M. Bastos Pereira das. op. cit., p. 148.

${ }^{91}$ François Furet definiu a "fórmula Antigo Regime" no contexto da Revolução Francesa: "[a acepção] abrangia tudo o que indicava as resistências ou simplesmente as inércias do passado, opostas ao esforço coletivo para instaurar a ordem nova, condição da felicidade coletiva. Já não era apenas a sociedade feudal o Antigo Regime, em comparação com a sociedade de indivíduos livres; ou um caos de instituições disparatadas, que abafava o reino da lei; ou o despotismo dos reis, em contraste com a República dos cidadãos. Era também um conjunto de traços de mentalidade, de hábitos e de costumes que se opunha ao imperativo da Revolução que consistia em formar um homem novo (...) pois de que valia fazer boas leis, se o atraso dos costumes e dos espíritos as impedia de frutificar?". Cf. FURET, François. "Antigo Regime”. In: FURET, François; OZOUF, Mona (orgs.). Dicionário Crítico da Revolução Francesa. São Paulo: Nova Fronteira, 1989, p. 621-631.

${ }^{92}$ BAKER, Keith Michael. "Soberania". In: FURET, François; OZOUF, Mona (orgs.). op. cit., p. 885-886.
} 
relação de simbiose com a Igreja Católica é significativo deste diagnóstico. Emília Viotti da Costa, por exemplo, destaca estes dois aspectos limitadores do liberalismo brasileiro. Para a autora, a essência das ideias liberais, importadas da Europa, era incompatível, sob muitos aspectos, com a realidade luso-brasileira. Isso se dava porque os maiores transmissores dessas ideias advinham de "categorias rurais e suas clientelas", que não estavam dispostas a renunciar à propriedade escrava ${ }^{93}$. De fato, ao estabelecerem os critérios de cidadania do Império do Brasil, os deputados excluiriam os escravos e, consequentemente, grande parcela da população brasileira. Apesar de muitos reconhecerem a escravidão como o "cancro virulento e mortífero" do Estado brasileiro e vislumbrarem o seu fim próximo, os constituintes não admitiam a cidadania plena para os cativos, como se depreende da fala do deputado Montesuma, mulato baiano ${ }^{94}$ :

E quanto aos crioulos cativos, Deus queira que quanto antes purifiquemos de uma tão negra mancha as nossas instituições políticas; Deus queira que em menos de um ano extirpemos do coração do Estado cancro tão virulento e mortífero; mas enquanto o não fazemos de força havemos confessar que não entram na classe dos Cidadãos, que não são membros de nossa política Comunhão, e, portanto, que não são Brasileiros no sentido próprio, técnico das Disposições Políticas. São homens para não serem tiranizados; mas (permita-me o uso da expressão dos Jurisconsultos, bem que bárbara, mas é política) enquanto ao exercício de direitos na sociedade são considerados coisas, ou propriedade de alguém; como tais as Leis o tratam, e reconhecem..$^{95}$

Para os deputados, os escravos, mesmo aqueles que alcançassem a alforria, eram indignos do "título" de cidadãos, por conta de sua "incivilidade" e "falta de virtudes". É por isso que, quando se discute a liberdade de culto no Brasil, sequer são consideradas as religiões afro-brasileiras, entendidas àquela época como "idolatrias", crenças e superstições que não mereciam maior atenção dos constituintes. Para os primeiros parlamentares do país, a nação brasileira era formada, em sua quase totalidade, por católicos romanos. As outras religiões reconhecidas como tais resumiam-se, no território nacional, ao protestantismo e ao judaísmo, cultos professados por "ilustres e úteis" estrangeiros que por ventura viessem a se instalar no Brasil. A esses, reservava-se a

\footnotetext{
93 COSTA, Emília Viotti da. "Introdução ao estudo da Emancipação Política do Brasil”. In: Da Monarquia à República: momentos decisivos. $9^{a}$ ed. São Paulo: Editora UNESP, 2010, p. 32.

94 A descrição de Francisco de Montesuma é feita pelo historiador José Honório Rodrigues. Cf. RODRIGUES, José Honório. A Assembleia Constituinte... op. cit., p. 123.

${ }^{95}$ Diário da Assembleia Geral, Legislativa e Constituinte... op. cit., t. III, p. 90.
} 
possibilidade de culto particular, sem forma exterior de templo. Às religiões afrobrasileiras restavam o preconceito e a discriminação, como se pode observar na fala do deputado pernambucano e latifundiário Manuel Caetano Almeida e Albuquerque:

E como se entenderá pelo Artigo em discussão que os escravos, pelo simples fato de obterem a Carta de Alforria, se façam Cidadãos? Falará o Artigo também dos escravos que vêm da Costa da África? Não lhes obstará o serem eles Pagãos, e outros Idólatras? Prescindindo desta razão, que me parece mui justa, como é possível que um homem sem Pátria, sem virtudes, sem costumes, arrancado, por meio de um comércio odioso, do seu território, e trazido para o Brasil, possa por um simples fato, pela vontade de seu Senhor, adquirir de repente na nossa sociedade direitos tão relevantes? ${ }^{96}$

Outro aspecto "limitador" do liberalismo brasileiro é a influência da Igreja Católica nos negócios públicos e na vida cotidiana da sociedade. Tal influência torna-se evidente quando não se cogita, na Assembleia Constituinte, a hipótese de um Estado laico, nem mesmo por aqueles que defendiam a liberdade de culto. A Religião Católica, como viria anunciado no art. 16 do Projeto de Constituição, era a "religião do Estado por excelência, e única mantida por ele". Emília Viotti da Costa também destaca o catolicismo como traço bastante característico dos brasileiros ao comentar o teor dos cartazes afixados em Recife por ocasião da Revolução de 1817, em que se liam: "Viva a Pátria", "Viva Nossa Senhora", "Viva a Santa Religião Católica"97. Ou seja, mesmo em contextos revolucionários não se atacavam a religião católica e a instituição da Igreja, situação bem diferente do que acontecera na França de 1789. Para as elites políticas, portanto, o catolicismo continuava sendo o "fundamento moral" da sociedade, especialmente de uma sociedade bastante inculta e incivilizada como era a brasileira de início do Oitocentos. Nesse sentido, Lúcia Neves destaca como um dos valores da cultura política lusobrasileira daquele período a defesa de "uma monarquia constitucional, que continuava aliada à Igreja, colocada doravante a seu serviço, pois ainda se fazia necessária a doutrina cristã para um maior controle dos cidadãos" 98 .

Não surpreende, portanto, que a abertura dos trabalhos constituintes no Brasil fosse revestida de "auspícios religiosos" - a expressão é de Pedro Calmon" ${ }^{99}$-, que

\footnotetext{
${ }^{96}$ Ibidem, p. 134.

${ }^{97}$ COSTA, Emília Viotti da. "Introdução ao estudo da emancipação...”. op. cit., p. 34.

${ }^{98}$ NEVES, Lúcia M. Bastos Pereira das. op. cit., p, 151.

${ }^{99}$ CALMON, Pedro. "Introdução". In: Diário da Assembleia Geral, Legislativa e Constituinte do Império do Brasil (1823). Brasília: Senado Federal, 2003, tomo I, s/ página.
} 
incluem desde a realização de uma missa pelo Bispo Capelão-Mor e deputado constituinte, d. José Caetano da Silva Coutinho, até a entoação do hino Veni Creator Spiritus e do tradicional Te Deum Laudamus, além do juramento sobre os Evangelhos. Ademais, as eleições realizavam-se no interior das paróquias, aos cuidados da Igreja, e a coroação dos imperadores brasileiros dava-se "sob a graça de Deus e aclamação dos povos", de forma que não se abandonavam completamente a liturgia do Antigo Regime. A "sagrada e santa" Constituição aceitava mesclar o sagrado e o profano, sacralizar-se para "se tornar respeitável, temida e venerada"; tal procedimento evidenciava que a obra de secularização política ainda estava incompleta ${ }^{100}$.

A relação íntima entre Estado e Igreja no Brasil remonta ao período colonial, tendo início com a instituição do regime do Padroado. Esse sistema, herdado da monarquia lusa, estabelece-se na América Portuguesa com a criação do primeiro bispado, em 1551, na Bahia, e prevalece até a Proclamação da República, em 1889, quando o país deixa de ter uma religião oficial. O regime jurídico do Padroado é, em sua expressão mais simples, uma "troca de obrigações e de direitos entre a Igreja e um indivíduo, ou instituição, que assume assim a condição de padroeiro" ${ }^{101}$. No caso do Império Português, e posteriormente do Império do Brasil, o padroeiro era o próprio monarca. Era ele quem ordenava a nomeação de bispos, a criação de igrejas, bispados e paróquias, distribuía as côngruas para manutenção do clero e recolhia o dízimo dos devotos. Para que bulas e outros documentos episcopais tivessem validade em território nacional, era necessário o assentimento do Estado por meio do beneplácito; já os recursos à Coroa consistiam em uma apelação para que a justiça civil revisasse qualquer sentença eclesiástica. Desta forma, as relações institucionais entre Estado e Igreja no Brasil eram marcadas por forte regalismo, ou seja, pela ingerência daquele nos assuntos desta ${ }^{102}$.

Em 1936 e 1960, respectivamente, Sérgio Buarque de Holanda e Roque Spencer Barros trouxeram à tona a polêmica do "falso" ou "singular" catolicismo brasileiro do Oitocentos, segundo o qual "nem os imperadores, nem os homens cultos, nem o clero, nem o povo poder-se-iam definir como católicos, na acepção exata do termo, embora

\footnotetext{
${ }^{100}$ NEVES, Lúcia M. Bastos Pereira das. op. cit., p. 155.

${ }^{101}$ NEVES, Guilherme Pereira das. "A religião do império e a Igreja”. In: GRINBERG, Keila; SALLES, Ricardo (orgs.). O Brasil Imperial, volume I: 1808-1831. Rio de Janeiro: Civilização Brasileira, 2009, p. 382.

102 Sobre o regime do Padroado régio, cf. CORDEIRO, Cecília Siqueira. A liberdade religiosa na Assembleia Constituinte de 1823. Monografia de final de curso. Universidade de Brasília, Brasília, 2013, especialmente cap. 2 .
} 
católicos se declarassem todos eles" ${ }^{\prime 103}$. Para os autores, foi justamente esse catolicismo frouxo, quase desrespeitoso e "estranho às almas verdadeiramente religiosas"104 que permitiu o modus vivendi em que se arrastavam as relações entre a Igreja Católica e o Império, sempre marcadas pela crença na supremacia do Estado sobre a Igreja. Segundo Roque Spencer Barros,

assim se explica o aparente paradoxo (...), a contradição entre a lei e a realidade impedindo o conflito potencial entre Igreja e Estado de manifestar-se. Se ninguém, rigorosamente falando, levava a peito a defesa das prerrogativas da Igreja, protestando contra as invasões do Estado no domínio espiritual ou, por outro lado, pretendendo ampliar a jurisdição daquela sobre o domínio temporal deste, como poderia eclodir o conflito de poderes? Reinava assim a paz, embora se tratasse de uma paz precária, que a qualquer instante poderia ser rompida, desde que aparecessem uns poucos campeões da religião romana dispostos a fazer valer no país o catolicismo em sua integridade, para tanto invocando o caráter oficial de sua crença. ${ }^{105}$

Para Roque Spencer Barros, a paz precária teria fim com a eclosão da Questão Religiosa $^{106}$ em meio do movimento de reação ultramontana da década de 1870 , representando o ápice da crise entre Estado e Igreja no Brasil no século XIX. Falso, frouxo ou desrespeitoso, o fato é que a grande maioria da população brasileira se considerava genuinamente católica. Essa precária secularização marcou as relações institucionais do Brasil Império, além, é claro, de definir os traços do catolicismo cotidiano, intimista e familiar. "Essa forma de culto", afirmaria Sérgio Buarque de Holanda, que tem antecedentes na Península Ibérica, aparece com a "decadência da religião palaciana, superindividual, em que a vontade comum se manifesta na edificação dos grandiosos monumentos góticos" e torna-se mais humana e singela. Assim, "cada casa quer ter sua capela própria, onde os moradores se ajoelham ante o padroeiro e protetor", seja ele o Menino Jesus ou a Santa Terezinha - ou Santa Tereza de Lisieux -, caracterizando um culto amável, quase fraterno, característico do "homem cordial"107 brasileiro.

\footnotetext{
${ }^{103}$ BARROS, Roque Spencer M. de. "Vida religiosa". In: HOLANDA, Sérgio Buarque de; CAMPOS, Pedro Moacyr (dirs.). História Geral da Civilização Brasileira. O Brasil Monárquico. Declínio e queda do Império, t. II, v. 4. $2^{\text {a }}$ ed. São Paulo: Difusão Europeia do Livro, 1974, p. 324.

${ }^{104}$ HOLANDA, Sérgio Buarque de. Raízes do Brasil. 26ª ed. São Paulo: Companhia das Letras, 1995, p. 149.

${ }^{105}$ BARROS, Roque Spencer M. de. "Vida religiosa"... op. cit., p. 324.

106 A Questão Religiosa (1872-1875) foi uma crise e ameaça de cisma entre o Estado e a Igreja, protagonizada pelos bispos de Olinda e do Pará, D. Vital e D. Macedo Costa, e pelo Imperador D. Pedro II, que culminaria na prisão dos bispos. Cf. PEREIRA, Nilo. Conflitos entre a Igreja e o Estado no Brasil. $2^{\mathrm{a}}$ ed. Recife: Editora Massangana, 1982.

${ }^{107}$ HOLANDA, Sérgio Buarque de. op. cit., p. 149.
} 
Independente da forma assumida, o fato é que o catolicismo praticado no país adquiriu contornos bem específicos e singulares. Essa forma de expressão religiosa característica da cultura luso-brasileira do Oitocentos também representou um limite ao liberalismo importado da Europa, que acabou por adaptar-se a essa mentalidade, da mesma forma como ocorreu com a escravidão.

Apesar das particularidades, como a convivência com o trabalho compulsório e a ausência de secularização, o que as elites políticas e, mais especificamente, os deputados constituintes professavam no pós-Revolução Constitucionalista era, sem dúvida, o liberalismo. Liberalismo esse que se expressava inclusive no novo vocabulário político, cujas "palavras de ordem" passaram a ser representação, igualdade, Constituição, soberania da nação e, principalmente, liberdade. Tal termo, segundo Lúcia Neves, "tornou-se a essência da vida do homem, não apenas em seus aspectos relativos às instituições e aos costumes, mas nos 'menores atos da vida individual e da vida comum""108. Porém, a medida dessa liberdade, bem como diferentes acepções de soberania, seriam motivos de controvérsia entre os membros das elites políticas, o que nos leva à segunda nuance dos referidos espectros políticos.

Nesse segundo nível, a orientação liberal das elites políticas assumia duas facetas distintas, mais perceptíveis após a crise dos anos 1820. A primeira delas, de caráter mais radical e avançado, admitia uma forma mais irrestrita de liberdade (civil, política, religiosa), e mais facilmente aceitava e defendia a supremacia do poder Legislativo sobre as arbitrariedades do Executivo - associadas, em primeiro grau, aos ministros e, em seguida, ao Imperador. Para os liberais radicais, a soberania emanava mais da nação do que do próprio rei, ainda que fosse partilhada entre os dois. No outro extremo do espectro político, encontrar-se-iam os membros das elites políticas com tendências mais conservadoras. Eram liberais - era impossível não o ser após o triunfo constitucionalista -, mas temiam os "excessos" de liberdade, e para tanto apostavam em uma Coroa forte para conter quaisquer desordens. Para eles, a soberania residia, em primeiro lugar, na pessoa do monarca, que como um verdadeiro pai saberia quais as melhores opções para seus súditos, cabendo-lhe regular o poder Legislativo, quando necessário.

A questão da soberania, como bem nos lembra a historiadora Tereza Kirscher, já havia sido discutida pelos constituintes franceses em 1789. Destacaram-se, naquela época, duas concepções distintas de soberania. A primeira, defendida pelo abade Sieyès,

\footnotetext{
${ }^{108}$ NEVES, Lúcia M. Bastos Pereira das. op. cit., p. 141.
} 
pressupunha "uma monarquia, na qual a nação, representada por uma Assembleia eleita, detinha a soberania absoluta"; ao soberano caberia apenas o papel de executor das leis aprovadas pela Assembleia. A outra corrente, defendida por Mounier, "embora admitisse a soberania nacional como princípio de legitimidade da ordem pública", atribuía à Coroa o "papel de guardiã dos interesses nacionais, a quem caberia o direito de veto às decisões da Assembleia". Desta forma, os "monarquianos" - como eram chamados os partidários de Mounier - inauguravam a modernidade política na França "sem fazer completa tábula rasa do passado"109. As duas concepções de soberania ressoaram na Constituinte brasileira, respondendo aos interesses de diferentes grupos, que aqui nomeamos como radicais e conservadores.

Entre os primeiros, vale ressaltar que seus principais expoentes foram perseguidos e muitos deles se viram obrigados a deixar o país antes mesmo do início da Constituinte, taxados de "republicanos" e "anarquistas", como foi o caso de Januário da Cunha Barbosa, José Clemente Pereira, João Soares Lisboa, Cipriano José Barata e Joaquim Gonçalves Ledo. Estes dois últimos chegaram a ser eleitos para a Assembleia, mas não tomaram assento - o primeiro foi eleito deputado com mais votos pela província da Bahia, e o segundo elegeu-se pelo Rio de Janeiro, obtendo também a maioria dos votos. Foram substituídos, respectivamente, por Carneiro de Campos e Silva Lisboa, figuras que representavam o oposto de um liberalismo radical.

Durante a Assembleia, porém, alguns deputados defenderiam essa corrente de pensamento mais radical, entre eles José Custódio Dias, Francisco Gê Acayaba de Montesuma, padre Venâncio Henriques de Resende e monsenhor Francisco Muniz Tavares. Além de se posicionarem favoráveis à liberdade de culto, outros posicionamentos ao longo da Constituinte permitem localizá-los nesse espectro político de um liberalismo radical. Por exemplo, ainda durante as sessões preparatórias para as Cortes, José Custódio Dias, deputado eleito por Minas Gerais, apresentaria uma emenda para que se substituíssem os termos da fórmula de juramento proposta por Antonio Carlos Ribeiro de Andrada. A fórmula fixava as funções da Assembleia - "fazer a Constituição política do Império do Brasil, e as reformas indispensáveis e urgentes" - e delimitava os poderes dos constituintes. Dias sugeriu a substituição dos termos "reformas indispensáveis e urgentes" pelas seguintes palavras:

109 KIRSCHNER, Tereza Cristina. José da Silva Lisboa, visconde de Cairu. Itinerários de um ilustrado luso-brasileiro. São Paulo: Alameda; Belo Horizonte: PUC-Minas, 2009, p. 235. 
Que os representantes da Nação, que se vai constituir, tendo por fito o melhoramento, e maior bem da mesma, nenhum limite circunscreverão às suas funções, que aqueles que ditados pela razão e justiça estiverem a seu alcance. ${ }^{110}$

Custódio Dias justificava-se como se previsse o fim que a Constituinte acabou levando - sua dissolução abrupta -, esclarecendo que "por maior que sejam o entusiasmo que de presente todos manifestam, eu não cantarei o triunfo antes da vitória". Defendia que as atribuições dos deputados - e, portanto, da Assembleia - fossem ilimitadas. Muitos preopinantes insurgiram-se contra sua fala, demonstrando que "seria absurdo supor que os representantes da nação tenham poderes ilimitados"111. Ao fim e ao cabo, a Assembleia aprovou a fórmula apresentada por Antonio Carlos, que, entre outras coisas, jurava manter “a Religião Católica Apostólica Romana e a Independência do Império, sem admitir com alguma Nação qualquer outro laço de união ou federação, que se oponha à dita Independência", de sorte que seria mantido "o Império Constitucional, e a dinastia do Senhor D. Pedro, nosso primeiro Imperador, e sua descendência"112.

O mesmo Dias acenderia nova polêmica quando da votação dos artigos do Projeto de Regimento concernentes ao cerimonial e formalidades da sessão solene inaugural e do recebimento do Imperador em Plenário ao questionar a posição do trono real nesta sessão. Segundo o exposto no regimento, d. Pedro sentar-se-ia acima do presidente da Assembleia, o que foi imediatamente combatido por aquele constituinte, para quem o representante do poder Executivo deveria "respeitar a nação legitimamente representada da qual só deriva toda a autoridade que pelo pacto social se lhe vai conferir por lei fundamental”. Assim, Dias propunha que a posição que se devia assegurar ao Imperador fosse "distinta, mas no mesmo plano onde estiver o Sr. Presidente [da Assembleia]"113. Sua proposta foi duramente criticada por Antonio Carlos, para o qual haveria uma hierarquia clara entre o "representante hereditário da nação" e seus "representantes temporários", os deputados:

Sr. Presidente, eu estava preparado para ouvir portentos nesta Assembleia, vivemos na idade das maravilhas, e somos mui pouco ilustrados para não ferverem entre nós milagres. Confesso, porém, que o que ouço passa toda a minha expectação, com quanto grande ela fosse. Que paridade há entre o representante hereditário e um único representante temporário, que, bem que

\footnotetext{
${ }^{110}$ Diário da Assembleia Geral, Legislativa e Constituinte... op. cit., t. I, p. 4.

${ }^{111}$ Idem.

112 Ibidem, p. 3-4.

113 Ibidem, p. 5.
} 
condecorado com o título de presidente, não é mais que seus iguais? ${ }^{114}$

Evidentemente, para os constituintes que defendiam um liberalismo mais radical, a autoridade do monarca jamais estaria acima da autoridade do corpo Legislativo, legitimamente escolhido pela nação - e representante dos direitos desta. Temiam as arbitrariedades e exorbitâncias do poder Executivo, criticando, sempre que possível, as atitudes tomadas pelos ministros de d. Pedro. Na sessão de 18 de outubro, por exemplo, quando a crise entre os dois poderes se acirrava, o deputado Francisco de Montesuma apresentaria uma indicação para que se retirasse a concessão de título de Marquês do Maranhão ao escocês Thomas Cochrane, até que a Assembleia estabelecesse por lei a ordem e gradação dos “Títulos que devem fazer a Grandeza e Fidalguia da Nação Brasileira":

\begin{abstract}
A Nação, quando nos mandou para aqui, foi com o fim de provermos ao bem público; e ainda que se não marcassem explicitamente as nossas atribuições, como declarou que queria o sistema de Governo Monárquico-Representativo, declarou que queria a divisão dos três Corpos independentes, tendo cada um destes as atribuições que lhe competem (...) Eu estou persuadido, segundo os meus princípios, que houve positiva ingerência do Poder Executivo na criação do Título de Marquês do Maranhão para Lord Cochrane. Só ao Poder Legislativo pertence marcar ordens de Nobreza para o Império; feito isto, dará então os Títulos o Poder Executivo. ${ }^{115}$
\end{abstract}

E prosseguia, afirmando que "o mesmo Lord Cochrane, que foi embalado no berço da liberdade, e nutrido (...) com leite constitucional" não poderia acusá-lo de desrespeito, já que reconhecia "os bons serviços por ele feitos à Nação Brasileira". Para o deputado, tratava-se apenas de "satisfazer os deveres sagrados da Representação da Nação"116 e da necessidade de se estabelecer primeiro em lei a ordem e gradação dos títulos de nobreza, para que só assim o Executivo possa concedê-los. Em sessão anterior, aos 11 de outubro, Montesuma havia criticado a postura do ministro da Guerra, que queria remeter ao Rio de Janeiro os soldados portugueses feitos prisioneiros na guerra da Bahia para que fossem incorporados ao Batalhão do Imperador. Para ele, o ministro era "inimigo da Causa do Brasil" e "abusa[va] do Nome de seu Monarca", e por isso requeria a sua demissão para "mostrar que não somos mudos espectadores de malversações" e para "evitar que não

\footnotetext{
114 Idem.

${ }^{115}$ Diário da Assembleia Geral, Legislativa e Constituinte... op. cit., tomo III, p. 264.

${ }^{116}$ Ibidem, p. 265.
} 
volte o antigo sistema" ${ }^{\prime 17}$. Vigiava-se, portanto, as recentes conquistas do Constitucionalismo, temendo quaisquer atitudes despóticas dos membros do Executivo, os quais deveriam submeter-se ao novo pacto social, de forma a não interferirem nas questões legislativas.

Quanto aos membros das elites políticas com orientações mais conservadoras no/do espectro político liberal, pode-se afirmar que defendiam a soberania nos moldes formulados por Mounier e pelos “monarquianos" franceses de 1789. Ou seja, para eles, a soberania da nação residiria, em primeiro lugar, na figura do monarca, que havia sido aclamado pelo povo e pelas câmaras municipais - ótica típica de Antigo Regime. O pacto social entre o Imperador e seus súditos surgiria no momento da aclamação, e não pela Constituição; a Assembleia só fora convocada graças à magnânima bondade do soberano, que poderia dissolvê-la a qualquer instante. Aliás, quando do encerramento abrupto dos trabalhos da Constituinte, muitos liberais conservadores mantiveram-se próximos a $\mathrm{d}$. Pedro, inclusive compondo seu ministério e elaborando a Constituição outorgada de 1824, com a promessa de fazê-la "duplicadamente mais liberal"118 do que o projeto que estivera em votação na Assembleia. Entre seus expoentes, destacam-se José Joaquim Carneiro de Campos - que substituiria José Bonifácio na pasta do Império e dos Negócios Estrangeiros -, Luís José de Carvalho e Mello, Manoel Jacinto Nogueira da Gama, João Severiano Maciel da Costa e José da Silva Lisboa.

O próprio Imperador d. Pedro I é um grande defensor, se não o maior, do liberalismo conservador, o que transparece em sua Fala do Trono dirigida aos constituintes por ocasião de sua instalação:

Como Imperador Constitucional e mui principalmente como Defensor Perpétuo deste Império, Disse ao Povo no Dia $1^{\circ}$ de Dezembro do ano próximo passado em que Fui Coroado, e Sagrado, Que com a Minha Espada Defenderia a Pátria, a Nação e a Constituição, se fosse Digna do Brasil, e de Mim. Ratifico hoje mui solenemente perante vós esta promessa, e Espero, que Me ajudeis a desempenhá-la, fazendo uma Constituição sábia, justa, adequada e executável, ditada pela Razão, e não pelo capricho, que tenha em vista somente a felicidade geral, que nunca pode ser grande, sem que esta Constituição tenha bases sólidas, bases que a sabedoria dos séculos tenha mostrado que são as verdadeiras para darem uma justa liberdade aos povos, e toda a força necessária ao Poder Executivo. Uma Constituição em que os três Poderes sejam bem divididos, de forma que não

\footnotetext{
${ }^{117}$ Ibidem, p. 229.

118 Decreto régio de 12 de novembro de 1823 apud RODRIGUES, José Honório. A Assembleia Constituinte... op. cit., p. 305.
} 
possam arrogar direitos que lhe não compitam; mas que sejam de tal modo organizados e harmonizados, que se lhes torne impossível, ainda que pelo decurso do tempo, fazerem-se inimigos, e cada vez mais concorram de mãos dadas para a felicidade geral do Estado. (...) Todas as Constituições, que a maneira das de 1791 e 1792 têm estabelecido suas bases, e se têm querido organizar, a experiência nos tem mostrado que são totalmente teoréticas e metafísicas, e por isso inexequíveis; assim prova a França, Espanha e, ultimamente, Portugal. Elas não têm feito, como deviam, a felicidade geral, mas sim, depois de uma licenciosa liberdade, vemos que em uns Países já apareceu, e em outros ainda não tarda a aparecer o Despotismo em um, depois de ter sido exercido por muitos, sendo consequência necessária ficarem os povos reduzidos à triste situação de presenciarem e sofrerem todos os horrores da anarquia. ${ }^{119}$

Deste modo, d. Pedro somente consentiria com a Constituição elaborada pelos representantes da nação caso fosse digna do Brasil, e dele. Nessa ótica, o soberano, principal elemento do corpo social, saberia exatamente do que a nação precisava, como um pai sabe o que é melhor para os seus filhos: "a vontade do povo fora previamente transmitida ao príncipe e ele era seu interlocutor privilegiado" ${ }^{120}$, nas palavras de Tereza Kirschner. Há também um cuidado na escolha das palavras, principalmente quando se trata da liberdade, que jamais deve ser entendida como irrestrita e "licenciosa", mas antes "justa", ordenada e controlada em prol da "felicidade geral" da nação. Quando se está diante de uma liberdade absoluta, desmedida, sofre-se com o despotismo de um (o monarca), que se vê obrigado a agir assim para conter o despotismo de muitos e os "horrores da anarquia".

Seu discurso gerou alguns constrangimentos aos deputados, surtindo críticas e apoio a sua postura. O deputado pernambucano e padre Luís Inácio de Andrada Lima é o primeiro a questionar o que chamou de "palavras ambíguas" no discurso de Sua Majestade. Para ele, apesar de ter sido "sem dúvida concebida em termos constitucionais", a fala de d. Pedro levava a crer que a Assembleia poderia fazer uma Constituição indigna do Brasil, e, portanto, do Imperador, correndo o risco de estabelecer "bases (...) teoréticas e metafísicas, e por isso inexequíveis" - o que ele discordava completamente, já que dos "sentimentos nobres e patrióticos"121 dos deputados só poderia nascer uma Constituição digna e justa.

\footnotetext{
${ }^{119}$ Diário da Assembleia Geral, Legislativa e Constituinte... op. cit., t. I, p. 18.

${ }^{120}$ KIRSCHNER, Tereza Cristina. op. cit., p. 236.

${ }^{121}$ Diário da Assembleia Geral, Legislativa e Constituinte... op. cit., t. I, p. 27-28.
} 
Custódio Dias, deputado mineiro, também questiona as palavras "demasiadamente gerais" de d. Pedro. Para Dias, o julgamento da Constituição só competia aos representantes da nação. Além do mais, perguntava-se: "se confiamos tudo dele, por que não confia Ele também tudo de nós?" ${ }^{122}$. Já o português José Antônio da Silva Maia, eleito deputado por Minas Gerais, sugeria que o Imperador expressasse à Constituinte "sucinta e brevemente as condições em que quer entrar no Pacto Social", para "que não aconteça trabalharmos e perdermos o tempo", com um possível veto do monarca à Constituição. Justificava-se afirmando que antes mesmo da reunião da Augusta Assembleia, d. Pedro já havia sido aclamado e sagrado Imperador do Brasil, e, portanto, os deputados deveriam considerá-lo um "Contratante de alta e reconhecida dignidade, que deve ser atendido e respeitado na organização da Constituição"123. Muniz Tavares levanta-se imediatamente para combater a fala do deputado Maia, que considera contrária aos ideais liberais:

Nós fomos eleitos para fazer uma Constituição; e para fazermos não se nos mandou pedir bases; uma proposição tal não deve jamais consentir-se que passe entre nós. Se o Monarca, por infelicidade nossa (o que não creio), julgar que a Constituição, que com desvelo pretendemos fazer, não merece a sua aprovação, ele seguirá o que a sua consciência lhe ditar; preferirá antes deixar de reinar entre nós; fará o que a prudência lhe aconselhar, entretanto que nós vamos também fazendo aquilo de que somos incumbidos. ${ }^{124}$

Custódio Dias pede a palavra novamente para defender as prerrogativas da Assembleia Constituinte. Discursando em tom ousado e provocativo, posiciona-se contra o temor do Imperador de que a Constituição garantisse uma liberdade "licenciosa":

O Povo Brasileiro tem posto em nós sua confiança, e espera que façamos uma Constituição digna dele, mas eu me considero e a todos nós em críticas circunstâncias, logo que se suscita a questão se Sua Majestade Imperial merece mais amor ao Público, e tem mais influência na opinião geral do que a Assembleia; pois em tal caso poderá Ele dar uma Constituição, ou pelo meio da força descoberta, ou por qualquer maneira injusta, entretanto que o Povo nos encomendou uma Constituição mui conforme aos seus sentimentos, donde se segue que depois de nos termos exposto a muitos incômodos, e perigos, talvez tenhamos a sorte que quase sempre cabe aos defensores da liberdade. Eu não quero a liberdade licenciosa, mas a liberdade bem entendida; e a favor

\footnotetext{
122 Ibidem, p. 28.

${ }^{123}$ Idem.

${ }^{124}$ Idem.
} 
dela sempre clamarei, como órgão do Povo, sem jamais me desviar deste caminho por temor ou covardia. ${ }^{125}$

José da Silva Lisboa, futuro visconde de Cairu, tomaria assento na Assembleia apenas em agosto, substituindo "seu adversário político e ideológico"126 Cipriano Barata, deputado eleito com mais votos pela província da Bahia. Lisboa acompanharia, por meio da publicação de seu periódico Atalaia, os trabalhos constituintes, inclusive combatendo a postura dos preopinantes que criticaram a fala do Imperador:

\begin{abstract}
Alguns deputados ostentaram liberdade da moderna alquimia de extrair veneno do mel da fala de S.M.I. (...) só porque o Príncipe da Nação também usou de sua inata liberdade, declarando que fazia o aceite da Constituição se fosse digna do Brasil, e de si, para não se submeter ao jugo de ferro do juramento prévio. ${ }^{127}$
\end{abstract}

Quando, em sessão de 9 de junho, o deputado cearense e ex-revolucionário de 1817, José Rodrigues de Carvalho, propõe uma indicação ao Governo para que se processasse o autor de uma carta "anticonstitucional e incendiária", publicada no Diário do Governo, periódico oficial do Estado, José da Silva Lisboa se pronunciaria novamente por meio do Atalaia. A carta, assinada com a iniciais G. P. T, foi considerada ultrajante por Rodrigues de Carvalho, Carneiro da Cunha e Henriques de Rezende, obra de "falsos Constitucionais, que pretendem com o encanto da lisonja envenenar" a alma do Imperador, porque declarava que a nação conferira "a Sua Majestade Imperial um poder sem limites, isto é, absoluto" 128 . Sob tal lógica, a Assembleia constituía-se como um poder delegado pelo monarca, isto é, sem soberania. No Atalaia, Silva Lisboa, que já havia exercido o cargo de censor régio, pronunciou-se favorável à liberdade de opinião, afirmando que as ordens da Assembleia para que autores anônimos de cartas publicadas no Diário do Governo fossem processados causavam um mal-estar desnecessário: "não estando ainda julgadas as bases da Constituição, haveria de se arvorar no Pão de Açúcar, a bandeira vermelha da intolerância de opiniões e da infalibilidade da Assembleia?" ${ }^{129}$.

Desde sua posse na Assembleia, aos 5 de agosto, Silva Lisboa "se tornaria uma das maiores figuras da Constituinte" ${ }^{130}$. Segundo Tereza Kirschner, seus discursos, longos e "entremeados de referências a autores clássicos e contemporâneos e a

\footnotetext{
125 Ibidem, p. 29.

${ }^{126}$ RODRIGUES, José Honório. A Assembleia Constituinte... op. cit., p. 160.

${ }^{127}$ Atalaia, 26 de julho de 1823 apud KIRSCHNER, Tereza Cristina. op. cit., p. 234.

${ }^{128}$ Diário da Assembleia Geral, Legislativa e Constituinte... op. cit., t. I, p. 187.

${ }^{129}$ KIRSCHNER, Tereza Cristina. op. cit., p. 239.

${ }^{130}$ RODRIGUES, José Honório. A Assembleia Constituinte... op. cit., p. 27.
} 
experiências de outros países", eram marcados pela "coerência das suas argumentações e pelo apoio sistemático ao governo"131. Quando finalmente passou-se à discussão do Projeto de Constituição, em inícios de setembro, acenderam-se vigorosas discussões acerca dos conteúdos dos primeiros capítulos. $\mathrm{O}$ artigo $2^{\circ}$, que estabelecia as províncias que fariam parte do Império, suscitou o debate em torno das palavras "federação" e "confederação". Ainda segundo Kirschner, tal embate demarcou as posições entre os defensores do governo e a oposição. Antonio Carlos, Silva Lisboa e Carvalho e Mello, por exemplo, defenderam que as palavras federação ou confederação implicavam "alianças entre estados independentes", além de estarem "implicitamente associadas ao republicanismo ou a algum grau de democracia" ${ }^{132}$. Nesse sentido, uma Constituição que promulgasse a união de províncias confederadas seria incompatível com uma monarquia constitucional. Temiam a dissociação do Império, o republicanismo e a democracia, e por isso apoiavam um governo central forte.

Já os deputados que compunham a "oposição ao governo", como Montesuma, Vergueiro e Carneiro da Cunha, deputados que, nesse aspecto, expressavam um liberalismo mais radical, mostrar-se-iam favoráveis à fórmula da confederação ou federação. Para eles, este formato não ia de encontro com a opção da monarquia constitucional, tampouco favoreceria um governo republicano tal qual acontecia nos Estados Unidos da América. Tratava-se apenas de conceder certa independência às províncias, conservando-se, todavia, a unidade do todo. "Os negócios que pertencem a todos, sejam dirigidos por todos, mas os que pertencem à parte, sejam dirigidos por essa parte" ${ }^{133}$, defenderia Nicolau de Campos Vergueiro.

\footnotetext{
Os defensores de um governo centralizado percebiam a consolidação nacional a partir e por meio do Estado, ao qual caberia disseminar, com sua autoridade, a ideia de nação brasileira no interior das províncias. Os "federalistas domésticos", ao contrário, concebiam a nação a partir do espaço de garantias de direitos e liberdades dos municípios e das províncias. (...) A construção da nação consistiria na dinâmica de ampliação da pátria de cada um, fundindo-se na grande pátria brasileira. ${ }^{134}$
}

\footnotetext{
${ }^{131}$ KIRSCHNER, Tereza Cristina. op. cit., p. 241.

${ }^{132}$ Ibidem, p. 248.

${ }^{133}$ Diário da Assembleia Geral, Legislativa e Constituinte... op. cit., t. III, p. 48.

${ }^{134}$ KIRSCHNER, Tereza Cristina. op. cit., p. 249.
} 
Quanto à pauta social do projeto constitucional, Silva Lisboa, deputado tradicionalmente rotulado como "conservador" pela historiografia, posicionar-se-ia de forma bastante avançada para o seu tempo, em relação ao liberalismo proposto e praticada à época. Quando se debatia o já citado artigo que tratava da cidadania dos escravos libertos, Silva Lisboa "pronunciaria um dos discursos mais notáveis da Assembleia, pela liberalidade das ideias e substância dos argumentos" ${ }^{135}$. Declarava-se contrário a qualquer restrição de cidadania aos escravos forros, tenha sido a liberdade adquirida por carta de alforria ou por quaisquer outros meios legítimos, pois desta forma adquiria-se o estatuto de pessoa civil, mesmo que não se adquirissem direitos políticos. Para Lisboa, os escravos libertos,

uma vez que adquiriram qualidade de pessoa civil, merecem igual proteção da Lei, e não podem ter obstáculo de arrendar e comprar terras, exercer qualquer indústria, adquirir prédio, entrar em estudos públicos, alistar-se na Milícia e Marinha do Império. ${ }^{136}$

Mas, ressaltava: direitos cívicos não correspondiam a direitos políticos. Concedia aos escravos apenas a primeira gama de direitos, que se restringiam a "dar ao homem livre o jus a dizer: tenho uma Pátria, pertenço à tal Cidade ou Villa; não sou sujeito à vontade de ninguém, mas só ao Império da Lei”. Diferentemente de outros deputados, acreditava que "mesmo os africanos, não obstante as arguições de gentilidade e bruteza, são suscetíveis de melhora mental, até por isso mesmo que se podem dizer tábuas rasas". Finalizaria, questionando a Assembleia com uma lógica razoável: "Sr. Presidente, em tempo de liberalismo, será a legislatura menos equitativa que no tempo do despotismo?"137.

Significativamente, outros liberais conservadores não concordariam com Silva Lisboa. É o caso do "ultraconservador" - o termo é utilizado por José Honório Rodrigues ${ }^{138}$ - Maciel da Costa, que afirmaria em Plenário: “espanta-me ver que o Africano [que] apenas obtiver sua carta de alforria, que é um título que simplesmente o habilita para dispor de si e do seu tempo, passe ipso facto para o grêmio da família Brasileira, para [ser] nosso irmão"139. Temia que os africanos não se afeiçoassem ao

\footnotetext{
${ }^{135}$ RODRIGUES, José Honório. A Assembleia Constituinte... op. cit., p. 132.

${ }^{136}$ Diário da Assembleia Geral, Legislativa e Constituinte... op. cit., t. III, p. 135.

${ }^{137}$ Idem.

${ }^{138}$ RODRIGUES, José Honório. A Assembleia Constituinte... op. cit., p. 133.

${ }^{139}$ Diário da Assembleia Geral, Legislativa e Constituinte... op. cit., t. III, p. 136.
} 
Brasil, "onde viveram escravizados", e que, "se sabendo eles que nos são equiparados, apenas forros, não aspirarão a avançar mais adiante na escala dos direitos sociais”, tendo em vista a "sua superioridade numérica e a consciência de sua força..."

Em se tratando de liberalismo conservador, talvez a figura que mais coerente e visivelmente o tenha representado seja José Joaquim Carneiro de Campos, futuro Marquês de Caravelas. Era ele o principal advogado do Poder Moderador, cuja adoção defendera na Constituinte "como meio indispensável, no Brasil, de conciliação entre ordem e liberdade"141, e que acabaria sendo incorporada à Constituição outorgada de 1824, da qual seria o principal redator. Carneiro de Campos substituiria ninguém menos que José Bonifácio no principal ministério do Império, marcando o afastamento dos Andradas de d. Pedro I. Segundo Christian Lynch, o deputado seria "defensor de um projeto constitucional com uma Coroa forte", responsável por expender "na Constituinte os mais sofisticados argumentos na tentativa de convencer os deputados a conferir ao Imperador os poderes políticos que ele julgava necessários para a consolidação do Estado brasileiro".

Avesso "ao construtivismo de um Rousseau ou Sièyes" ${ }^{142}$, Carneiro de Campos buscaria inspiração em Montesquieu, em Mounier e, é claro, em Benjamin Constant. Carneiro de Campos será o "principal introdutor do discurso monarquiano" no Brasil, segundo o qual "o próprio monarca figurava como principal defensor de um bem público constantemente ameaçado pela corrupção das facções" ${ }^{143}$. Ainda na visão de Lynch, Antonio Carlos, principal redator do projeto de Constituição, havia elaborado o projeto de forma "apressada e prolixa". O futuro Marquês de Caravelas, entretanto, "sob o olhar atento do Imperador, que o visitava quase diariamente, e graças a sua vasta cultura política e jurídica", elaborou, "no exíguo prazo de oito dias", um projeto "mais preciso e mais conciso" do que o anterior, "tecnicamente bastante superior" ${ }^{144}$. Sua maior inovação seria justamente a inclusão de um quarto poder, o Moderador, "destinado a assegurar ao Imperador o papel de gerente do sistema constitucional" ${ }^{\prime 145}$.

Nessa ótica, a monarquia constitucional caracterizava-se pela "integração do monarca no processo legislativo, por meio do direito de veto dos projetos de lei que

\footnotetext{
${ }^{140}$ Ibidem, p. 137.

${ }^{141}$ LYNCH, Christian Edward. "A vocação sociológica do legislador: o pensamento político do Marquês de Caravelas”. In: RIBEIRO, Gladys Sabina (org). op. cit., p. 149.

142 Idem.

143 Ibidem, p. 150.

${ }^{144}$ Ibidem, p. 153.

${ }^{145}$ Ibidem, p. 154.
} 
julgasse formal ou materialmente nocivos à causa pública"146. Seguia, portanto, a orientação monarquiana segundo a qual o chefe da nação era o guardião da Constituição, "preservando-a das tendências que tinham as Assembleias de expandir seus poderes". O veto ao poder Legislativo - cujo extremo será a dissolução do parlamento - era uma atribuição do Poder Moderador, entendido por Carneiro de Campos e seus partidários como um "poder de exceção a serviço da salvaguarda do sistema constitucional", responsável por solucionar o

problema central da política moderna: forjar uma ordem institucional capaz de equilibrar as justas aspirações à liberdade, materializadas no reconhecimento dos direitos fundamentais dos cidadãos e da esfera social, de um lado, e a necessidade de ordem, materializada na preservação da segurança pela autoridade pública no âmbito do Estado, de outro. ${ }^{147}$

Carneiro de Campos defenderia abertamente na Constituinte o Poder Moderador, em sessão de 26 de junho:

Cumpre que jamais percamos de vista que o Monarca Constitucional, além de ser o Chefe do Poder Executivo, tem de mais a mais o caráter Augusto de Defensor da Nação: Ele é a sua primeira Autoridade vigilante, guarda dos nossos direitos e da Constituição. Esta Suprema Autoridade, que constitui a sua Pessoa sagrada e inviolável, e que os mais sábios Publicistas deste tempo têm reputado um Poder Soberano distinto do Poder Executivo por sua natureza, fim e atribuições, esta Autoridade, digo, que alguns denominam Poder Neutro, ou Moderador e outros Tribunício é essencial aos governos representativos. ${ }^{148}$

Maciel da Costa, em sessão de 23 de setembro, também reforçaria a defesa do Poder Moderador, postulando que o Imperador seria a "sentinela permanente" da nação:

Sabemos todos que em um Governo Constitucional, o Supremo Chefe, além do Poder Executivo para a simples execução de Leis tem o Supremo Poder Moderador, em virtude do qual ele vigia como de atalaia sobre todo o Império, é a sentinela permanente, que não dorme, não descansa; é o Argos político que com cem olhos tudo vigia, tudo observa, e não só vigia, e observa, mas tudo toca, tudo move, tudo dirige, tudo concerta, tudo compõe, fazendo aquilo que a Nação faria, se pudesse, mas sendo preciso cometê-lo a alguém, tem mostrado a razão, e a experiência, que

\footnotetext{
${ }^{146}$ Ibidem, p. 157-158.

${ }^{147}$ Ibidem, p. 158.

${ }^{148}$ Diário da Assembleia Geral, Legislativa e Constituinte... op. cit., t. I, p. 300.
} 
vale mais cometê-lo a uma pessoa física, que a uma pessoa moral, isto é, uma Corporação. ${ }^{149}$

O quarto poder seria, assim, um poder discricionário exercido "emergencialmente pelo chefe do Executivo para salvar o regime representativo nascente do perigo da desagregação do corpo político; uma espécie de freio de mão leviatânico”, necessário em um Estado constitucional incipiente e frágil, “despido de tradições e por isso ameaçado por seu próprio déficit de legitimidade" 150 . Devido às condições nacionais da época, Carneiro de Campos e Maciel da Costa acreditavam que "o regime de liberdade e de igualdade vinha do alto", haja vista que o povo não estaria pronto para um regime constitucional pleno, "tomando-o como sinônimo de liberdade absoluta, ou seja, como o fim de toda e qualquer hierarquia ou respeito à autoridade" ${ }^{151}$. É por isso que muitos membros das elites políticas defensoras de um liberalismo mais conservador não condenaram a dissolução da Assembleia, tendo inclusive se beneficiado com ela. Acreditavam, portanto, que apenas um governo central forte "poderia superar os impasses que se apresentavam para transformar o Brasil em um país civilizado"152.

No início de novembro, os ânimos da Constituinte acirraram-se ainda mais com a publicação de um artigo veiculado pelo periódico Sentinela da liberdade à beira-mar da Praia Grande, sob o pseudônimo de "Brasileiro Resoluto", que criticava os portugueses que haviam sido incorporados às tropas brasileiras. Alguns oficiais portugueses, alvos das críticas, agrediram, por engano, o boticário Davi Pamplona, acreditando ser ele o autor do artigo. Como avalia Kirschner, "um incidente que em outras circunstâncias não teria tido tanta repercussão, naquela conjuntura adquiriu importância política"153. Pamplona enviaria uma carta à Assembleia relatando os fatos; a leitura de sua carta inflamou os espíritos dos constituintes, entre eles Antonio Carlos, que se mostrava contrário à incorporação de portugueses em tropas brasileiras. À medida que a crise se aprofundava, as galerias da Cadeia Velha, sede da Constituinte, permaneciam abarrotadas de populares, de forma que o deputado Alencar pediu permissão ao Presidente para que as pessoas pudessem entrar no recinto dos deputados, o que foi deferido. Imediatamente José da Silva Lisboa reagiu, receando tumultos:

\footnotetext{
${ }^{149}$ Diário da Assembleia Geral, Legislativa e Constituinte... op. cit., t. III, p. 87.

${ }^{150}$ LYNCH, Christian Edward. “A vocação sociológica...” op. cit., p. 158-159.

${ }^{151}$ Ibidem, p. 162.

${ }^{152}$ KIRSCHNER, Tereza Cristina. op. cit., p. 256.

${ }^{153}$ Ibidem, p. 254.
} 
Senhores, não vamos levar a praça de assalto, não queiramos renovar a cena horrorosa da Praça do Comércio de 21 de Abril, quando os Eleitores foram encurralados e obraram sem liberdade e se precipitaram a desatinos. ${ }^{154}$

Antonio Carlos Andrada Machado replicaria o velho deputado, ironizando-o: "O que me admira é haver tanto medo do Povo, e tão pouco da tropa. No meio do Povo Brasileiro nunca podemos estar mal"155. Sua fala recebeu vários apoiados, tanto de deputados como das galerias. Desde o incidente com Davi Pamplona, havia uma agitação das tropas em torno do prédio da Assembleia, deixando a todos apreensivos. Carneiro de Campos chama à ordem pontuando que não era permitido ao "povo" das galerias que manifestassem seus sentimentos, condenando os gritos de "apoiados" e requerendo o encerramento da sessão.

Na sessão seguinte, temendo os avanços das tropas, o deputado Antonio Carlos propõe que a Assembleia se declarasse em sessão permanente, o que foi aprovado. Discutiu-se ainda a necessidade de chamar o ministro da Guerra para esclarecimentos acerca do incidente envolvendo oficiais portugueses e o boticário, e a possibilidade de a Assembleia reunir-se em outro local, longe do cerco das tropas. A madrugada de 11 para 12 de novembro ficou conhecida como "a longa noite da agonia" ${ }^{156}$, tendo fim com a chegada de um ofício do Imperador, às 11 horas da manhã, pelas mãos de seu ministro Vilela Barbosa. Ao entrar o dito ministro em Plenário, observou-se que deveria deixar sua espada do lado de fora, ao que respondeu: "Esta espada é para defender a minha Pátria, e não para ofender os Membros da Augusta Assembleia; portanto, posso entrar com ela"157. Após um breve interrogatório, em que o português Vilela Barbosa declarava a intenção do Imperador - " $1^{\circ}$, que se coibisse imediatamente a liberdade de imprensa; $2^{\circ}$, (já que me obrigam a referir nomes de pessoas que aliás prezo) que fossem expulsos da Assembleia os Senhores Andradas"158 -, afirmando que Sua Majestade se sentira ameaçado física e politicamente pelo Tamoio, periódico ligado aos irmãos Andradas.

No início da tarde, os deputados retiraram-se pacificamente da Assembleia, atitude que, para José Honório Rodrigues, "honra o Brasil e o Parlamento Brasileiro"159.

\footnotetext{
${ }^{154}$ Diário da Assembleia Geral, Legislativa e Constituinte... op. cit., t. III, p. 389.

155 Idem.

${ }^{156}$ Cf. PEREIRA, Vantuil. “A longa 'noite da agonia'”. In: Revista de História, janeiro de 2012, disponível em: $\quad$ http://www.revistadehistoria.com.br/secao/artigos-revista/a-longa-noite-da-agonia. Acesso: 07/02/2016.

${ }^{157}$ Diário da Assembleia Geral, Legislativa e Constituinte... op. cit., t. III, p. 406.

${ }^{158}$ Ibidem, p. 407.

${ }^{159}$ RODRIGUES, José Honório. A Assembleia Constituinte... op. cit., p. 222.
} 
Logo na saída foram presos, cumprindo ordens do Imperador, os deputados Antonio Carlos Andrada Machado, Martim Francisco Ribeiro de Andrada, Belchior Fernandes Pinheiro, José Joaquim da Rocha e Francisco Gê Acayaba de Montesuma. Foram, então, conduzidos ao cais do Largo do Paço, embarcados em um navio guarnecido de tropa e levados ao Arsenal da Marinha, para depois serem deportados. Antônio Carlos ao sair preso e acompanhado de soldados, "tirou o chapéu a uma peça de artilharia que estava apontada para a porta que ele acabara de franquear, e disse: Respeito muito o seu poder" ${ }^{160}$. José Bonifácio, que não se encontrava presente na Assembleia em razão de licença, foi preso em casa. Acabaram presos, mas depois libertados, os deputados Muniz Tavares, Henriques de Resende, Carneiro da Cunha, Alencar, Cruz Gouveia Xavier de Carvalho e Luís Inácio de Andrade Lima, todos identificados com uma corrente mais radical no/do espectro político do liberalismo. A primeira experiência parlamentar do Brasil conhecia seu fim abrupto e violento.

Segundo Lúcia Neves, a reorganização do governo de d. Pedro, no que diz respeito tanto à substituição do ministério dos Andradas, quanto à dissolução da Assembleia, ganhou fôlego após a chegada de notícias de Portugal. Menos de um ano depois de promulgada a Constituição portuguesa pelas Cortes Gerais, em 3 de junho de 1823, o movimento conhecido como Vila Francada interrompia a experiência liberal naquele país, fechando o Congresso pela força das armas. O infante d. Miguel lideraria o movimento, inspirado no cenário internacional: tropas francesas haviam invadido a vizinha Espanha em nome da Santa Aliança para reconduzir o monarca ao poder e liquidar o regime constitucional. Esse movimento de reação deflagrado em consonância com as decisões do Congresso de Viena e da formação da Santa Aliança assegurou "a restauração dos legítimos soberanos", refez "o mapa da Europa" e criou "um concerto de nações destinado a evitar quaisquer novos focos revolucionários" ${ }^{\prime 61}$.

As restaurações na Europa e, posteriormente, no Brasil não significaram, contudo, o simples retorno ao absolutismo e ao Antigo Regime, uma vez que o liberalismo já havia imprimido a sua marca no mundo, provocando uma definitiva "mutação da política em coisa pública, constituindo um primeiro liberalismo, cujos avatares decisivos, porém, viriam apenas em 1830 e 1848"162. Tratava-se, sim, de uma configuração política receosa dos arroubos democráticos da Revolução Francesa, que tentava conciliar ordem e

\footnotetext{
${ }^{160}$ Idem.

${ }^{161}$ NEVES, Lúcia M. Bastos Pereira das. op. cit., p. 413.

${ }^{162}$ Ibidem, p. 414.
} 
liberdade, e que, para tanto, flertava com alguns elementos do antigo sistema, seja ele a opção do uso repressivo das tropas, a institucionalização do veto do soberano no processo legislativo ou mesmo a manutenção da simbiose entre Igreja Católica e Estado.

Por fim, cabe falar das figuras mais controversas da Constituinte, que ao longo dos seus seis meses de funcionamento movimentaram-se entre os espectros políticos de um liberalismo ora mais conservador, ora mais radical. Os irmãos Andrada - José Bonifácio, Martim Francisco e Antonio Carlos - iniciaram seus trabalhos na Assembleia defendendo fielmente as prerrogativas do soberano. A partir de julho, passaram a criticar o governo de d. Pedro, acusado de tendências absolutistas, por meio das folhas do jornal O Tamoio. Acabaram presos e exilados na França, a mando do Imperador.

A trajetória de Antonio Carlos teve maiores reviravoltas. Em carta para o irmão Martim Francisco, datada de 29 de março de 1817, descreveria o "sucesso de Pernambuco": "Particulares e autoridades, tudo tem reconhecido o novo Governo e a forma republicana"163. À época ouvidor da comarca de Olinda, viu-se seduzido pela bandeira do republicanismo e da Independência, aderindo à Revolução. Quando o movimento foi vencido pelas tropas do Rio de Janeiro, Antonio Carlos, juntamente com outros líderes da revolução, entre eles Muniz Tavares, Frei Caneca e Cipriano Barata, foi enviado a uma prisão na Bahia. Defenderia mais uma vez a "bandeira da Independência" por ter sido eleito deputado às Cortes Gerais, partindo para Lisboa em 1821. Lá, notabilizou-se por advogar pelas prerrogativas nacionais, recusando-se a jurar a Constituição elaborada e fugindo para o Brasil, acompanhado pelo restante da deputação de São Paulo, vindo tomar parte no processo de Independência. Nesse momento, sofrera ataques dos portugueses devido a seu "passado democrático", como visto no início do capítulo.

Passaria então, ao lado de seus irmãos que comporiam o ministério, a empreender forte defesa das prerrogativas reais. Pelo tom de seus discursos na Constituinte, os Andradas viam com otimismo a administração de d. Pedro, acreditando tratar-se de um monarca liberal, envolvido com a "causa da nação". Ao longo dos primeiros meses de Assembleia, defendiam - principalmente Antonio Carlos, um dos mais ativos deputados - a justa e harmoniosa divisão dos poderes. Buscavam a não interferência da Assembleia nos assuntos do Executivo, e em caso de conflitos, tendiam para a superioridade do "poder

\footnotetext{
163 Cartas Andradinas. Correspondência particular de José Bonifácio, Martim Francisco e Antonio Carlos dirigida a A. de M. Vasconcellos de Drummond. Rio de Janeiro: Anais da Biblioteca Nacional do Rio de Janeiro, 1890, p. 73. Disponível em: http://www2.senado.leg.br/bdsf/item/id/242471. Acesso: 08/02/2016.
} 
hereditário" do monarca sobre o "poder temporário" dos deputados. José Bonifácio, em discurso a favor da tão criticada Fala do Trono que abrira os trabalhos da Constituinte, sairia em defesa do Imperador, evidenciando sua posição antagônica com relação aos que ele designava como "mentecaptos revolucionários":

Como é possível que hajam homens que do mel puro do discurso de Sua Majestade Imperial destilem veneno? Eu não acho nas expressões do Imperador se não as nossas próprias expressões, e a vontade geral do Povo do Brasil. Que quer este Povo? E para que tem trabalhado até agora tanto o Governo? Para centralizar a união, e prevenir as desordens que procedem de princípios revoltosos. O Povo do Brasil, Sr. Presidente, quer uma Constituição, mas não quer demagogia e anarquia (...) a guerra terrível que eu poderia fazer seria contra esses mentecaptos revolucionários que andam, como em mercados públicos, apregoando a liberdade, esse bálsamo da vida de que eles só se servem para indispor os encantos. ${ }^{164}$

O biógrafo Octávio Tarquínio de Souza assim descreveria a ação de Bonifácio na Constituinte:

José Bonifácio temia que o espírito demagógico tomasse conta da Assembleia e impusesse soluções inadequadas e inexequíveis. E achava conveniente tornar claro aos deputados que o Imperador, com a instalação da Constituinte, não passara a ser uma figura meramente decorativa: os deputados tinham um mandato do povo para a feitura da Constituição, mas a esse mandato precederam o apelo popular ao príncipe d. Pedro para que ficasse no Brasil e a sua aclamação como Defensor Perpétuo (...) O mandato dos constituintes não era irrestrito e a forma de governo fora predeterminada: só poderia ser a monarquia constitucional. ${ }^{165}$

Mas, por volta de julho de 1823, a situação mudaria. Ainda segundo Tarquínio de Souza, o Imperador, "a exemplo do que acontece sempre com os indivíduos endeusados, fora aos poucos acreditando em todos os louvores, lisonjas e panegíricos", convencendose de que era "o herói da libertação brasileira". Passaria a rodear-se de "bajuladores e áulicos", que insinuavam que o monarca deveria prescindir da companhia de ministros "poderosos e conselheiros opiniáticos. Não agradava ao povo, sussurravam, que se ficasse como um pupilo nas mãos de quem quer que fosse, ainda um velho, um sábio, um grande

\footnotetext{
${ }^{164}$ Diário da Assembleia Geral, Legislativa e Constituinte... op. cit., t. I, p. 30.

165 SOUZA, Octávio Tarquínio. História dos fundadores do Império... op. cit., v. 1 (A vida de José Bonifácio), p. 253.
} 
homem"166. O autor atribui os sussurros a pessoas "da intimidade" de d. Pedro, como ao guarda-roupa João Maria da Gama Freitas Berquó, futuro Marquês de Cantagalo, e Gordilho Barbuda, depois marquês de Jacarepaguá, que teriam criado um "ambiente desfavorável"167. Isso sem falar em Domitila de Castro, amante do Imperador e futura Marquesa de Santos (título, aliás, concedido propositalmente para atingir os Andradas ${ }^{168}$ ), inimiga pessoal do ministro. Segundo Tarquínio de Souza, para abalar a relação entre d. Pedro e José Bonifácio, "melhor instrumento seria por certo uma voz feminina, a mesma das horas de abandono erótico, do que a de qualquer outros intrigantes, áulicos, ministros ou deputados" $" 169$.

Para o biógrafo de d. Pedro e de José Bonifácio, os conspiradores haviam minado o "amor-próprio" do Imperador: "Quem era afinal o monarca, o chefe? O ministro do Império ou d. Pedro? (...) Não queria passar por fraco, por príncipe que se deixasse dirigir fosse por quem fosse. E isto fez timbre em tornar bem claro ao seu grande ministro" ${ }^{170}$. Assim, "para mostrar que não era pupilo, e sim o Imperador”, d. Pedro afastar-se-ia dos Andradas, demitiria seu ministério, reorganizando-o com elementos favoráveis ao "partido português"171. Vale ressaltar que, desde que Muniz Tavares apresentara projeto na Assembleia acerca da situação dos portugueses no Brasil, os ânimos entre o que a historiografia tradicional chamou de "partido português" e "partido brasileiro" acirraramse. Segundo o projeto, os portugueses de "conduta suspeita" deveriam deixar o país em um prazo de três meses. Antonio Carlos e Martim Francisco mostrar-se-iam favoráveis ao projeto. Quanto a José Bonifácio, que não se pronunciaram na ocasião, Tarquínio de Souza é de opinião que o ministro estaria de acordo com o projeto, tendo em vista o estremecimento de sua relação com d. Pedro ${ }^{172}$.

\footnotetext{
${ }^{166}$ Ibidem, p. 257.

${ }^{167}$ SOUZA, Octávio Tarquínio. História dos fundadores do Império... op. cit., v. 3, (A vida de d. Pedro I, $2^{\circ}$ tomo), p. 524.

${ }^{168}$ Em carta para seu amigo Antônio de Menezes Vasconcellos de Drummond, datada de janeiro de 1826, o exilado José Bonifácio criticaria a concessão de títulos nobiliárquicos por parte de d. Pedro, a quem chamava de "imperial criança": "Quem creria possível que, nas atuais circunstâncias, a grã Pata pôr tantos ovos de uma vez, como 19 Viscondes e 22 Barões? Nunca o João pariu tanto na plenitude e segurança de seu poder autocrático. Quem sonharia que a michela Domitila seria Viscondessa da Pátria dos Andradas? Que insulto desmiolado!". Cf. Cartas Andradinas... op. cit., p. 14.

${ }^{169}$ SOUZA, Octávio Tarquínio de. História dos fundadores do Império... op. cit, v. 3, (A vida de d. Pedro I, $2^{\circ}$ tomo), p. 537.

${ }^{170}$ Ibidem, p. 537-538.

${ }^{171}$ SOUZA, Octávio Tarquínio de. História dos fundadores do Império... op. cit., v. 1 (A vida de José Bonifácio), p 262.

${ }^{172}$ Ibidem, p. 259.
} 
Lentamente, portanto, os Andradas se afastariam do governo, desconfiando de posições áulicas ou mesmo absolutistas do monarca, sobretudo após o sucesso do movimento restaurador português. Passariam, então, a contribuir com o periódico editado pelo amigo íntimo Antônio de Menezes Vasconcellos de Drummond, intitulado $O$ Tamoio. O periódico, cujo nome fazia alusão a uma tribo indígena que havia sido bastante hostil aos colonizadores, empreendeu ataques à administração imperial. "Mas, será um ataque indiscriminado e incoerente", uma vez que, para Caio Prado Júnior, José Bonifácio "tomara-se de um ódio que se pode dizer pessoal aos portugueses"173, que resultará na prisão dos Andradas ao final da Constituinte. Nesse sentido, pode-se dizer que José Bonifácio, Martim Francisco e Antonio Carlos moviam-se entre os espectros políticos do liberalismo, e por isso a frase de Emília Viotti da Costa sobre o mais velho dos irmãos nunca fez tanto sentido: para José Bonifácio, o líder do Executivo “devia menos ser um líder revolucionário, um representante do povo do que um déspota esclarecido, e menos um déspota esclarecido do que um monarca constitucional"174.

${ }^{173}$ PRADO JÚNIOR, Caio. “O Tamoio e a política dos Andradas...”. op. cit., p. 189.

${ }^{174}$ COSTA, Emília Viotti da. “José Bonifácio...". op. cit., p. 134. 


\section{Capítulo 3: Os debates sobre liberdade religiosa na Constituinte}

Não sejamos maus Políticos à custa de parecermos mui Católicos. ${ }^{1}$

Segundo José Honório Rodrigues, a primeira Constituição brasileira foi elaborada durante a Revolução Pernambucana, em 1817. A "lei orgânica, provavelmente de autoria do então ouvidor Antonio Carlos"2, continha 28 artigos. Reconhecia a soberania do povo, prometia uma futura Constituição a ser elaborada por uma Assembleia Constituinte, assegurava plena liberdade (inclusive de imprensa) e igualdade, além dos direitos fundamentais do homem e a estabilidade da magistratura. Declarava que a religião do Estado era a católica, tolerando as demais comunhões cristãs e proibindo a inquietação ou perseguição de alguém por "motivos de consciência"3. Quanto à escravidão, os "patriotas pernambucanos"4 admitiam-na como contrária aos ideais de justiça e igualdade, prevendo uma abolição lenta, gradual e legal. A lei orgânica teria curta duração - pouco mais de dois meses - e "influência ideológica" restrita a um "pequeno círculo

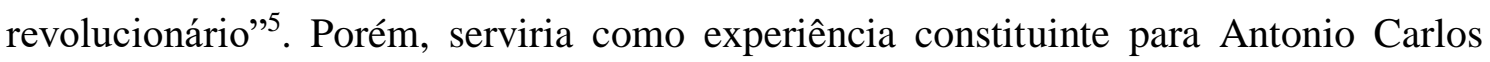
Ribeiro de Andrada Machado e Silva, principal redator do Projeto de Constituição apresentado à Assembleia Constituinte alguns anos depois.

Na sessão de 16 de agosto, Antonio Carlos comunicaria à Assembleia que o Projeto de Constituição, do qual havia sido o redator, estava finalizado. Tal projeto, elaborado por uma comissão composta por ele, Antônio Pereira da Cunha, Pedro de Araújo Lima, José Ricardo da Costa Aguiar, José Bonifácio de Andrada e Silva, Manoel Ferreira da Câmara e Francisco Muniz Tavares, contava com 272 artigos e era assinado por todos os membros - com restrições por Costa Aguiar e Muniz Tavares ${ }^{6}$. Para Homem de Mello, escrevendo em 1862 numa tentativa de restaurar a imagem da primeira

\footnotetext{
${ }^{1}$ Deputado Manoel de Souza França, discurso à Assembleia Constituinte, 29 de outubro de 1823. Apud Diário da Assembleia Geral, Legislativa e Constituinte do Império do Brasil (1823). Brasília: Senado Federal, 2003, tomo III, p. 332.

${ }^{2}$ RODRIGUES, José Honório. A Assembleia Constituinte de 1823. Petrópolis: Editora Vozes, 1974, p. 102. ${ }^{3}$ Idem.

${ }^{4}$ A expressão era utilizada pelos próprios revolucionários. Cf. CABRAL, Flávio José Gomes. Os patriotas. Pernambuco foi palco da primeira República do país. In: Revista de História, novembro de 2009, disponível em: http://www.revistadehistoria.com.br/secao/artigos/os-patriotas. Acesso: 22/02/2016.

${ }^{5}$ RODRIGUES, José Honório. op. cit., p. 102.

${ }^{6}$ Ibidem, p. 104.
} 
Constituinte brasileira, prejudicada pela avaliação negativa de autores como Varnhagen e Armitage $^{7}$, o projeto consagrava "todos os grandes princípios das liberdades constitucionais, todas as novas conquistas do sistema representativo" ${ }^{8}$, demonstrando que a Assembleia estava apta para fazer o seu trabalho, ou seja, para "reconstituir o país segundo a nova ordem das coisas"9.

Até que Antonio Carlos apresentasse, em nome da Comissão de Constituição, a versão finalizada do projeto, os deputados trataram de elaborar projetos de lei abordando os "pontos mais urgentes" 10 para a nação, de forma que foram apresentados, além dos projetos de Constituição e de Regimento, 38 projetos de lei, 147 propostas e 238 pareceres ${ }^{11}$ dos deputados e das diversas c omissões - um número razoável, considerando-se a curta duração da Assembleia. Entre as leis sancionadas ${ }^{12}$, destacam-se a lei que aboliu o Conselho de Procuradores das Províncias e a que regulamentou a liberdade de imprensa. Outros projetos de lei importantes tramitavam quando da dissolução, como por exemplo aqueles referentes à criação de universidades em território nacional, à mudança da capital para o interior do país e à naturalização de estrangeiros e de portugueses.

Finalmente, aos 15 de setembro iniciou-se a discussão do Projeto de Constituição, estendendo-se até 12 de novembro, data da dissolução da Assembleia. Nesse ínterim,

\footnotetext{
${ }^{7}$ O juízo de Varnhagen e Armitage acerca da Constituinte é bastante negativo. Para este último, por exemplo, os constituintes apresentavam "noções acanhadas [e eram] inclinados à realeza. A minoria era composta do clero subalterno e de proprietários de pequenas fortunas, ávidos de liberdade, mas liberdade vaga e indefinida, que cada um interpreta a seu modo, e guiavam-se por seus próprios sentimentos (...) excetuados os três Andradas, que tinham sido eleitos deputados, havia entre todos mui poucos indivíduos, se é que os havia, acima da mediocridade (...) Durante toda a sessão da Assembleia Constituinte, só passaram cinco projetos de leis, todos sobre objetos secundários, e pequeno progresso fez a discussão dos diversos artigos constitucionais". Já Varnhagen refere-se à Constituinte como um "grande erro", tendo em vista que a Assembleia se "emaranhava em largas discussões, em vez de realizar a obra para que principalmente se reunira; e que talvez houvera mal desempenhado, produzindo um parto informe das paixões do momento das votações, em vez de um código harmônico, como veio a ser a nossa atual Constituição". As citações se encontram em MELLO F. I. Marcondes Homem de. A Constituinte perante a História. Brasília: Senado Federal, 1996, p. 2 e 3.

${ }^{8}$ MELLO, F. I. Marcondes Homem de. A Constituinte perante a História (1862). Brasília: Senado Federal, 1996, p. 9.

${ }^{9}$ Ibidem, p. 8.

${ }^{10}$ Idem.

${ }^{11}$ RODRIGUES, José Honório. op. cit., p. 49

${ }^{12}$ Seis leis foram sancionadas e entraram em vigor: lei regulamentando a forma que devia ser observada a promulgação dos decretos da Constituinte, sem dependência da sanção imperial; lei que extinguia o Conselho de Procuradores das Províncias; lei que proibia os deputados de exercerem qualquer outro emprego durante o tempo de sua deputação, salvo os cargos de ministro e de intendente geral de polícia; lei que versava sobre as sociedades secretas, regulamentando-as; lei determinando a manutenção da legislação vigente e lei regulando a forma dos governos provinciais, que passariam a ser administrados por um presidente e um conselho. A lei que regulamentava a liberdade de imprensa foi proposta pela Comissão de Legislação aos 2 de outubro e decretada pelo Imperador em 22 de novembro de 1823. Cf. RODRIGUES, José Honório. op. cit., p. 100; MELLO, F. I. M. Homem de. op. cit., p. 9-10.
} 
foram aprovados 24 artigos. Destes, os artigos 18 (“A lei vigiará sobre as profissões que interessam os costumes, a segurança e a saúde do povo"), 19 ("Não se estabelecerão novos monopólios, antes as leis cuidarão de acabar com prudência os que ainda existem"), 20 ("Ninguém será privado de sua propriedade sem consentimento seu, salvo se o exigir a conveniência pública, legalmente verificada"), 21 ("Neste caso será o privado indenizado com exatidão, atendendo-se não só ao valor intrínseco, como ao de afeição, quando ela tenha lugar"), 22 (“A lei conserva aos inventores a prosperidade de suas descobertas, ou de suas produções, segurando-lhes o privilégio exclusivo temporário, ou remunerando-os em ressarcimento da perda que hajam de sofrer pela vulgarização") e 23 (“Os escritores não estão sujeitos à censura, nem antes nem depois de impressos, e ninguém é responsável pelo que tiver escrito ou publicado, salvo nos casos e pelo modo que a lei apontar”), foram aprovados sem discussão. Para José Honório Rodrigues, “como esses artigos foram discutidos a 7 e 11 de novembro, é natural que o nervosismo daqueles dias tenha impedido o debate"13. Nervosismo que se explicaria pela movimentação das tropas nas proximidades da Cadeia Velha, local onde os deputados se reuniam desde 3 de maio.

O conteúdo desses artigos aprovados sem discussão revela a inspiração liberal do Projeto de Constituição. São delimitadas as "modificações e explicações" ao direito de propriedade, incluídas aí possíveis indenizações e ressarcimentos, bem como à liberdade de expressão e de imprensa, proibindo-se a censura, salvo nos casos apontadas pela lei. Vale ressaltar que o artigo 23, último aprovado pela Assembleia, foi votado pouco antes da chegada das notícias envolvendo David Pamplona e os oficiais portugueses. Estes últimos, sentindo-se ofendidos após artigo publicado sob o pseudônimo de "Brasileiro Resoluto" no Sentinela, no qual seu ator criticava a incorporação de tropas portuguesas ao exército brasileiro, haviam agredido o boticário, apontado erroneamente como autor do artigo, o que acabou reacendendo a polêmica da liberdade de imprensa na Constituinte.

Os demais artigos que chegaram a ser votados antes da dissolução provocaram grandes debates entre os deputados, nomeadamente o artigo $2^{\circ}$, que versava sobre a divisão do território nacional, principalmente no que se refere ao uso da palavra "federação"; $4^{\circ}$, que dividia o país em comarcas; $5^{\circ}$, que definia quem eram os brasileiros - sendo que a discussão se estendeu por oito sessões; $6^{\circ}$, que regulamentava a naturalização dos estrangeiros; $7^{\circ}$, que listava os direitos individuais dos brasileiros e 13 ,

\footnotetext{
${ }^{13}$ RODRIGUES, José Honório. op. cit., p. 107, grifo nosso.
} 
que estabelecia o direito ao juízo dos jurados em matéria criminal. As discussões surgem porque os artigos tratavam de assuntos polêmicos e em voga naquela sociedade. A questão da federação, por exemplo, será associada pelos deputados ora à experiência norte-americana - digna de exemplo, embora muitos acreditassem impossível de se aplicar ao Brasil -, ora à ação de "republicanos, anarquistas e carbonários", ansiosos de estabelecer no país republiquetas à semelhança do que acontecia na América do Sul. A própria divisão do território nacional em comarcas, prevista no artigo $4^{\circ}$, trazia à tona preocupações com a manutenção da unidade territorial e do regime monárquico.

Já o artigo $5^{\circ}$, que delimitava quem eram os cidadãos brasileiros, suscitou o maior debate da Constituinte. A cidadania já havia sido tratada, de forma tangencial, durante as discussões dos projetos de lei que versavam sobre a naturalização dos estrangeiros (assunto reservado ao artigo $6^{\circ}$ do projeto de Constituição) e da admissão dos oficiais portugueses ao exército brasileiro. No caso do artigo $5^{\circ}$, os parlamentares buscaram definir quem eram os brasileiros, identidade que, como vimos, vinha sendo forjada desde fins de 1821, momento crucial de diferenciação entre os portugueses da América e da Europa. Por fim, estabeleceu-se que eram cidadãos brasileiros os homens livres nascidos no Brasil ou naturalizados, segundo critérios de filiação estabelecidos no artigo $6^{\circ}$, e os escravos libertos. Este último ponto geraria intensos e inflamados discursos, conforme abordado no capítulo 2 .

$\mathrm{O}$ artigo $5^{\circ}$, bem como os demais que tratavam de direitos e garantias fundamentais dos cidadãos brasileiros, teve um impacto significativo e imediato na sociedade, como se pode apreender a partir da carta enviada ao Correio do Rio de Janeiro por João José Pereira. Na carta, publicada em 28 de agosto de 1823 - concomitante aos debates travados na Constituinte -, João José, um negro livre, protestava contra a discriminação que sofrera por parte de "indiscretos liberais e mal-educados" em um teatro fluminense:

Tenho ouvido dizer que é cidadão todo o homem livre nascido no território brasileiro, seus filhos e os escravos que alcançam a alforria. Como é, Sr. Redator, que dando-se (sic) ao negro e ao pardo escuro, uma insígnia militar e honras correspondentes ao grau que ocupa ou na Milícia, ou na Igreja, ou nas Letras, se não permite a esse homem estar com sua mulher e filhas num camarote na casa da Ópera, fazendo os indiscretos liberais e maleducados os maiores insultos ao infeliz que se quer divertir e instruir-se naquela casa? (...) Igualdade é nome vão?!14

\footnotetext{
${ }^{14}$ Correio do Rio de Janeiro, $\mathrm{n}^{\mathrm{o}} .23,28$ de agosto de 1823 apud LUSTOSA, Isabel. LUSTOSA, Isabel. "O debate sobre os direitos do cidadão na imprensa da Independência”. In: RIBEIRO, Gladys Sabina;
} 
Percebe-se, portanto, que o "povo" se mantinha atento aos debates travados na Constituinte, cientes de que neste espaço eram garantidos seus direitos fundamentais, pelo menos no tocante à parcela livre da população brasileira. Gladys Ribeiro e Vantuil Pereira destacariam que,

quando começaram a discutir o Projeto de Constituição, as galerias da Assembleia ficaram lotadas. Os populares acompanharam o posicionamento dos parlamentares sobre os direitos civis e a opinião que tinham a respeito de ser membro de uma sociedade política. (...) No decorrer das sessões, centenas de petições foram encaminhadas aos deputados. (...) Indicavam avaliação acurada desses indivíduos com relação ao quadro político que lhes poderia propiciar um alargamento de direitos. (...) Podemos então, constatar que a movimentação nas ruas e nas galerias da Assembleia Constituinte já indicava a preocupação de vários setores com as decisões tomadas pelos constituintes. Ao longo das votações, a concorrência na plateia foi aumentando, a ponto das galerias serem pequenas para tamanha participação. ${ }^{15}$

Nesse sentido, a "ilha de letrados" formada pelos deputados constituintes estava, em tese, à serviço do "mar de analfabetos", do povo em geral. Este, por sua vez, mostravase tão ansioso por assegurar aquela "conquista recente, a ideia de direitos do cidadão", que empreendia uma espécie de vigilância constante para que "nem mesmo nos detalhes houvesse a possibilidade de se voltar ao Antigo Regime" "16. É por isso que em outra carta enviada ao Correio, em maio de 1823, um leitor anônimo, identificado como revisor de passaportes, denunciaria os artifícios de certos homens - "manhosos como jumentos" que teimavam em conservar nos passaportes o termo relativo a um tempo em que havia vassalos e não cidadãos:

Sr. Redator do Correio (...) Deu-me a mania de querer saber a razão porque se teima a escrever nos passaportes "vassalos?" e a que pude descobrir mais coerente ao meu modo de pensar foi a seguinte: que assim como há jumentos manhosos como certos homens, há também certos homens manhosos como jumentos. A Deus, Sr. Redator! Muitas recomendações às senhoras D.D. Imprensas, porque se elas se não compadecerem dos nossos corpos, não sei que será de nossas almas. Sou de V. M. já sabe

FERREIRA, Tânia Maria Tavares Bessone da Cruz. (orgs.). Linguagens e práticas da cidadania no século XIX. São Paulo: Alameda, 2010, p. 11.

${ }^{15}$ RIBEIRO, Gladys; PEREIRA, Vantuil. "O Primeiro Reinado em revisão". In: GRINBERG, Keila; SALLES, Ricardo (orgs.). O Brasil Imperial, volume I: 1808-1831. Rio de Janeiro: Civilização Brasileira, 2009, p.151-153.

${ }^{16}$ LUSTOSA, Isabel. “O debate sobre os direitos...”. op. cit., p. 16. 
quem; um revisor de passaportes; e detestador de tal palavrinha "vassalos". ${ }^{17}$

O tempo era de conquistas e garantias dos direitos fundamentais, adquiridas a partir da "nova ordem de coisas" do Oitocentos. Com relação aos direitos individuais dos brasileiros, elencados no artigo $7^{\circ}$, o parágrafo $3^{\circ}$ do referido artigo e os artigos 14,15 e 16, que versavam sobre a liberdade religiosa e suas limitações, seriam intensamente debatidos pelos deputados, suscitando inúmeras intervenções. A longa discussão iniciouse na sessão de 7 de outubro e, após aparecer na ordem do dia em sete sessões e provocar em torno de 70 manifestações, só seria concluída um mês depois, a menos de uma semana do fechamento da Constituinte. $\mathrm{O}$ debate sobre a liberdade religiosa, portanto, seria o segundo mais extenso da primeira Assembleia Geral, Legislativa e Constituinte do Brasil, ficando atrás apenas da discussão em torno do artigo $5^{\circ}$.

Tal debate revelaria as nuances do liberalismo professado pelos deputados, que flutuavam entre posições ora mais radicais, ora mais conservadoras com relação à matéria. Expressaria, também, as "mitigadas Luzes portuguesas", onde a noção moderna de liberdade religiosa conviveria com tradições próprias do Antigo Regime, como a manutenção de um culto oficial, único mantido pelo Estado. A Igreja católica mantinhase como aspecto fundamental da fisionomia da América portuguesa, agora Império do Brasil, entendida como fundamento moral da sociedade e um importante agente civilizador e moralizar da mesma.

Ao fim e ao cabo, os artigos, tal como foram aprovados, concediam uma razoável liberdade religiosa, uma vez que esta estendia-se apenas às comunhões cristãs. Quanto às demais religiões, caso não fossem destrutivas da moral e dos bons costumes, reservavase o culto particular e doméstico. Além do mais, muitos parlamentares preocuparam-se com a futura vinda de imigrantes - seja por motivos de povoamento do território, seja pela substituição da mão de obra escrava -, concedendo ao liberalismo que praticavam um caráter bastante pragmático e utilitarista, como a historiadora Maria Odila Dias ${ }^{18}$ já havia apontado.

A liberdade religiosa também despertaria o interesse da sociedade. Aos 5 de novembro de 1823 o Correio do Rio de Janeiro publicaria dois sonetos acerca da "ordem

\footnotetext{
${ }^{17}$ Correio do Rio de Janeiro, $\mathrm{n}^{\circ}$. 38, 24 de maio de 1822, apud LUSTOSA, Isabel. "O debate sobre os direitos...". op. cit., p. 16.

${ }^{18}$ DIAS, Maria Odila Leite da Silva. "Aspectos da ilustração no Brasil”. In: metrópole e outros estudos. $2^{\mathrm{a}} \mathrm{ed}$. São Paulo: Alameda, 2005. A interiorização da
} 
do dia" da Assembleia. Um dos poemas, assinado por "Corifeus amantes da Liberdade Religiosa", expressava em poucas linhas o pensamento majoritário da Constituinte sobre o tema, e que acabou vitorioso. Os autores destacavam a importância de se "atrair estranhos Povoadores ao Império do Brasil”, os quais nos discursos dos deputados eram chamados de estrangeiros úteis, referindo-se principalmente a protestantes ingleses e alemães. Condenavam, também, os "Despóticos ditames corruptores" dos tempos de servilismo e de Inquisição, pontos “obscuros” da história da Igreja que foram relembrados pelos constituintes, bem como o "execrável Fanatismo" de outras religiões, louvando a “Assembleia da Nação" por tê-lo suplantado e sustentado a religião católica:

Para atrair estranhos Povoadores Ao Império do Brasil, mimo de Jové, Sim, é preciso sim, que hoje se inove Sistema de Direitos Protetores;

Graças, Brasil, que teus Legisladores Das Leis etéreas, que um Deus nos chove Desde já vão banindo o que promove Despóticos ditames corruptores:

E vós, amantes vis do Servilismo Que quereis ver surgir a Inquisição Aferrados ao antigo Despotismo, Conheci, que a Assembleia da Nação Suplantando o execrável Fanatismo Sustenta, e não destrói a Religião. ${ }^{19}$

\section{Os atores dos debates: prosopografia}

Discursaram a respeito dos artigos referentes à liberdade de culto cerca de 25 deputados, ou 1/3 dos 84 constituintes, sendo seis representantes de Minas Gerais, cinco da Bahia, cinco de São Paulo, três de Pernambuco, três do Rio de Janeiro, um da Paraíba, um do Alagoas e um de Goiás, conforme indicado na tabela abaixo.

\footnotetext{
${ }^{19}$ Correio do Rio de Janeiro, $\mathrm{n}^{\circ}$ 80, 5 de novembro de 1823, p. 320.
} 


\begin{tabular}{|c|c|}
\hline \multicolumn{2}{|l|}{ Tabela 1 - Procedência dos deputados } \\
\hline Nome do deputado & Província \\
\hline José Custódio Dias & \multirow{6}{*}{ Minas Gerais } \\
\hline João Severiano Maciel da Costa & \\
\hline Manuel Rodrigues da Costa & \\
\hline Antonio da Rocha Franco & \\
\hline José Teixeira de Fonseca Vasconcelos & \\
\hline João Evangelista de Faria Lobato & \\
\hline José da Silva Lisboa & \multirow{5}{*}{ Bahia } \\
\hline Francisco Carneiro de Campos & \\
\hline Francisco Gê Acayaba de Montesuma & \\
\hline Luís José de Carvalho e Mello & \\
\hline Felisberto Caldeira Brant Pontes & \\
\hline Antonio Carlos Ribeiro de Andrada Machado e Silva & \multirow{5}{*}{ São Paulo } \\
\hline José Ricardo da Costa Aguiar & \\
\hline Nicolau Pereira de Campos Vergueiro & \\
\hline Manoel Joaquim de Ornellas & \\
\hline Francisco de Paula Souza e Mello & \\
\hline Venâncio Henriques de Resende & \multirow{3}{*}{ Pernambuco } \\
\hline Francisco Muniz Tavares & \\
\hline Manuel Caetano de Almeida e Albuquerque & \\
\hline Bispo Capelão-Mor & \multirow{3}{*}{ Rio de Janeiro } \\
\hline José Joaquim Carneiro de Campos & \\
\hline Manoel José de Souza França & \\
\hline Joaquim Manuel Carneiro da Cunha & Paraiba \\
\hline Caetano Maria Lopes Gama & Alagoas \\
\hline Silvestre Álvares da Silva & Goiás \\
\hline
\end{tabular}

Os maiores oradores, embora em campos opostos, foram José da Silva Lisboa, representante da Bahia, e Antonio Carlos de Andrada Machado, representante paulista. Quase tão participativos foram os deputados Montesuma, da Bahia, os padres Henriques de Resende e Muniz Tavares, eleitos por Pernambuco, o magistrado Manoel de Souza França, do Rio de Janeiro, e os representantes mineiros João Severiano Maciel da Costa e Manuel Rodrigues da Costa, também padre. É possível observar uma proeminência de deputados representantes de Minas Gerais e da Bahia, não por acaso as duas maiores bancadas da Assembleia Constituinte, a primeira com 20 e a segunda com 11 deputados.

Digna de nota é a tradição revolucionária, combatente e federalista das províncias do Nordeste, especialmente da Bahia e de Pernambuco, que enviaram expressivo número de deputados de orientação mais radical, como o baiano Montesuma e os pernambucanos Muniz Tavares e Henriques de Resende. Percebe-se na fala dos deputados, sobretudo quando da discussão sobre o local a serem fundadas universidades no Brasil, um forte 
ressentimento daquelas províncias do Norte do país com relação às do Sul, especialmente o Rio de Janeiro. Tal "descompasso de aspirações políticas”, como escreverá Evaldo Cabral de Melo, "originou a assimetria regional do processo de emancipação" ${ }^{20}$, do qual a Bahia será o maior exemplo, resistindo à autoridade central de d. Pedro até meados de 1823. A explicação de Cabral de Mello para o desacerto de interesses interprovincial será a existência, no Nordeste, de "sentimentos decididamente republicanos, reforçados sem dúvida pelo constante intercâmbio com os Estados Unidos"21. Não por acaso eclodiria, em 1824, a Confederação do Equador, movimento revolucionário federalista que teve como centro irradiador Pernambuco.

Um segundo aspecto importante para compor a prosopografia dos deputados é a faixa etária, cujos dados podem ser observados na tabela 2:

\begin{tabular}{|l|r|}
\hline \multicolumn{2}{|c|}{ Tabela 2 - Faixa etária dos deputados } \\
\hline Faixa etária & \multicolumn{1}{|c|}{ № } \\
\hline Até 30 anos & 3 \\
\hline 31 a 40 anos & 3 \\
\hline 41 a 50 anos & 5 \\
\hline 51 a 60 anos & 8 \\
\hline Acima de 60 anos & 2 \\
\hline Idade desconhecida & 4 \\
\hline Total & $\mathbf{2 5}$ \\
\hline
\end{tabular}

A partir dos dados especificados na tabela acima, observa-se que a maioria dos oradores possuía entre 51 e 60 anos - oito no total de 25 -, como é o caso, por exemplo, do Bispo Capelão-Mor, D. José Caetano da Silva Coutinho, e do mineiro João Severiano Maciel da Costa, que à época da Constituinte contavam 55 e 54 anos, respectivamente. Em segundo lugar, aparecem os deputados cujas idades variavam entre 41 e 50 anos cinco no total -, entre eles Antonio Carlos de Andrada Machado, que completara 50 anos poucos dias antes da dissolução da Assembleia, e Nicolau de Campos Vergueiro, que possuía 44 anos em 1823. As gerações nascidas nas décadas de 1760 e 1770, maioria na Constituinte, atingiram a vida adulta em meio à turbulência da Inconfidência Mineira e do avanço napoleônico em solo europeu, acompanharam a transferência da Corte para o Rio de Janeiro e acabaram adquirindo cargos na administração joanina.

\footnotetext{
${ }^{20}$ MELLO, Evaldo Cabral de. A outra Independência. O federalismo pernambucano de 1817 e 1824 . São Paulo: Editora 34, 2004, p. 29.

${ }^{21}$ Apud MELLO Evaldo Cabral de. op. cit., p. 29.
} 
Três são os deputados que se enquadram na faixa etária de 31 a 40 anos, como o padre Venâncio Henriques de Resende, que havia participado da Revolução de 1817 com 33 anos, contando 39 na época da Assembleia, e o sobrinho dos irmãos Andrada, José Ricardo da Costa Aguiar, que completou 36 anos durante a Constituinte. O grupo dos mais novos - até 30 anos - também conta com três representantes, entre eles o cônego Francisco Muniz Tavares, revolucionário de 1817, e o baiano Francisco Acayaba de Montesuma, que combatera as tropas do General Madeira na Bahia, demonstrando que havia espaço para a chamada "geração de 1790 "22 e para jovens lideranças na Constituinte. Muniz Tavares, "um dos vultos mais notáveis" ${ }^{23}$ da Revolução de Pernambuco, havia sido preso por conspiração e participação na revolução, juntamente com Antonio Carlos, Frei Caneca e Henriques de Resende. Segundo Sacramento Blake, "quando minoraram os rigores com que eram tratados ele e seus companheiros" 24 de prisão, permitiu-se a entrada de "livros de instrução", estabelecendo-se ali uma "espécie de ateneu" 25 , onde Antonio Carlos lecionava língua inglesa, direito natural e direito civil e Muniz Tavares ensinava lógica. É deste período o Soneto à Liberdade, escrito por Antonio Carlos, que diria muito sobre a atuação futura desses ex-revolucionários na Constituinte, avessos a qualquer "déspota sanhudo":

\author{
Sagrada emanação da Divindade, \\ Aqui do cadafalso eu te saúdo, \\ Nem com tormentos, com revezes mudos, \\ Fui teu votario e sou, ó liberdade! \\ Pode a vida brutal ferocidade \\ Arrancar-me em tormento mais agudo; \\ Mas das fúrias do déspota sanhudo \\ Zomba d'alma a nativa dignidade. \\ Livre nasci, vivi e livre espero \\ Encerrar-me na fria sepultura, \\ Onde Império não tem mando severo. \\ Nem da morte a medonha catadura \\ Incutir pó de horror a um peito fero, \\ Que aos fracos tão somente a morte é dura. ${ }^{26}$
}

\footnotetext{
${ }^{22}$ Sobre ao assunto, cf. MAXWELL, Kenneth. "A geração de 1790 e a ideia do império luso-brasileiro". In: _. Chocolate, piratas e outros ensaios tropicais. Rio de Janeiro: Paz e Terra, 1999, p. 157-207.

${ }^{23}$ BLAKE, Augusto Vitorino Sacramento. Dicionário bibliográfico brazileiro. Rio de Janeiro: Typographia Nacional, 1883, vol. 3, p. 59. Os 7 volumes da obra encontram-se no acervo digital da Câmara dos Deputados, disponível em: http://bd.camara.gov.br/bd/handle/bdcamara/14856. Acesso: 31/03/2016.

24 Idem.

${ }^{25}$ BLAKE, Augusto Vitorino Sacramento. op. cit., vol. 1, p. 120.

${ }^{26}$ Ibidem, p. 130.
} 
Já os deputados com mais de 60 anos eram poucos: apenas José da Silva Lisboa (67 anos) e o padre Manuel Rodrigues da Costa (69 anos). Nascidos na década de 1750, a trajetória política desses dois indivíduos foi bastante diversa. Enquanto o primeiro notabilizou-se por acumular cargos administrativos na monarquia lusa, demonstrando grande "lealdade à Coroa"27, o segundo envolver-se-ia na Inconfidência Mineira, valendo-se de "seu estado sacerdotal para não sofrer pena maior do que a de ser mandado para Lisboa em 1792, ficar preso na fortaleza de S. João da Barra por quatro anos e só obter a liberdade ao cabo de dez" 28 . A avançada idade de José da Silva Lisboa fazia com que os demais deputados o considerassem "ultrapassado e retrógrado" ${ }^{29}$, embora respeitassem a sua erudição. Para José Honório Rodrigues, o futuro Visconde de Cairu era a única figura da Constituinte comparável, em importância, a Antonio Carlos. Descrevia-o como um grande orador, que, contudo, era motivo de "riso" aos outros deputados:

Os grandes discursos de Silva Lisboa, na extensão e no conhecimento, são sempre coerentes. Ele não era temido como Antonio Carlos, antes provocava surpresa e riso. Quando se discutia, por exemplo, o preâmbulo do projeto de Constituição, ele criticou [que] se tivesse invocado apenas a Sabedoria Divina e não se tivesse feito nenhum ato de culto externo, como the parecia indispensável; e, para dar força à afirmativa, ajoelhou-se em plenário. (...) Quando censurava os figurantes da Revolução de 1817 e denunciava Pernambuco como foco do jacobinismo, muitos deputados o apartearam, e Silva Lisboa respondeu: "Tenho peito triplicado para resistir à rapaziada" 30 .

A análise das faixas etárias dos deputados envolvidos nos debates sobre liberdade religiosa permite-nos identificar algumas tendências. A primeira delas consiste em afirmar que os parlamentares mais idosos, como Rodrigues da Costa e Silva Lisboa, ambos com mais de 60 anos, posicionavam-se, nesta questão, mais próximos do campo político do liberalismo conservador. Fariam, portanto, uma defesa intransigente da Igreja católica, por eles entendida como fundamento moral e civilizar da sociedade, condenando, assim, a liberdade religiosa contida no projeto constitucional. Já os preopinantes mais jovens, que à época da Constituinte não contavam com 50 anos

\footnotetext{
${ }^{27}$ KIRSCHNER, Tereza Cristina. José da Silva Lisboa, visconde de Cairu. Itinerários de um ilustrado lusobrasileiro. São Paulo: Alameda; Belo Horizonte: PUC-Minas, 2009, p. 7.

${ }^{28}$ BLAKE, Augusto Vitorino Sacramento. op. cit., vol. 6, p. 188.

${ }^{29}$ KIRSCHNER, Tereza Cristina. op. cit., p. 241.

${ }^{30}$ RODRIGUES, José Honório. op. cit., p. 270.
} 
completos, como Muniz Tavares (30 anos), Henriques de Resende (39 anos), Montesuma (29 anos) e Costa Aguiar (36 anos), apresentam posições localizadas no extremo mais radical do campo político do liberalismo. Apesar de não abdicarem da condição de súditos de uma nação católica, criticarão os "abusos" cometidos pelos membros da Igreja no passado, chegando inclusive a considerar um "favor muito especial" o estabelecer-se, na Constituição política do Brasil, a religião católica como culto oficial. Logo, mostrar-seão favoráveis a uma liberdade religiosa mais irrestrita do que aquela esboçada no projeto, segundo a qual restringe-se o culto exterior apenas ao catolicismo, permitindo-se os demais em casas para isso destinadas.

Já a maioria dos deputados envolvidos nos debates sobre o tema será composta por cinquentenários que, por sua vez, adotarão uma postura mais moderada, conciliando posições ora do liberalismo radical, ora do liberalismo conservador. Ou seja, homens como Antonio Carlos (50 anos), Maciel da Costa (56 anos) e os irmãos Francisco e José Joaquim Carneiro de Campos (58 e 55 anos, respectivamente), defenderão a liberdade religiosa como direito individual dos brasileiros, princípio baseado na máxima de que a consciência e convicção pessoal são um santuário onde o Estado não deveria penetrar. Para esses deputados, a relação da criatura com o Criador transcende o poder humano, não sendo possível obrigar a nenhum cidadão seguir uma religião diferente do que a sua consciência o ditar. Contudo, sobretudo quando em discussão os artigos 14, 15 e 16 do projeto, defenderão limites e restrições à liberdade religiosa, como o culto externo restrito apenas aos católicos. Demonstram, também, em suas manifestações grande preocupação com os chamados "estrangeiros úteis", nomeadamente com os protestantes ingleses, importantes para o povoamento do país e a gradual substituição da mão de obra escrava. Ao fim e ao cabo, seus discursos - considerados menos "inconsequentes" do que os dos jovens parlamentares e menos "caducos" do que os defendidos pelos mais idosos convencerão os demais deputados, sendo a posição moderada a solução que sairia vitoriosa dos debates acerca da liberdade religiosa no Brasil.

Um terceiro aspecto analisado foi a formação superior dos deputados que tomaram parte no debate sobre a liberdade de culto, como especificado na tabela abaixo: 


\begin{tabular}{|l|r|}
\hline \multicolumn{2}{|c|}{ Tabela 3 - Formação superior dos deputados (Instituições) } \\
\hline Instituições & \multicolumn{1}{|c|}{ № } \\
\hline Universidade de Coimbra & 14 \\
\hline Academia Real dos Guardas-Marinhas (Lisboa) & 10 \\
\hline Não especificado & $\mathbf{2 5}$ \\
\hline Total & \\
\hline
\end{tabular}

Dos dados coletados, verifica-se que a maioria (15 dos 25 representantes) cursou o ensino superior em universidades europeias. Dentre as instituições de ensino, a Universidade de Coimbra foi o destino preferido dos deputados: 14 concluiriam seus estudos nessa universidade. Apenas o militar Felisberto Caldeira Brant Pontes, o “descobridor da conspiração mineira em 1789"31, foge à regra. Seguindo a carreira militar, formar-se-ia na Academia Real dos Guardas-Marinhas, localizada em Lisboa. Francisco Muniz Tavares, padre e revolucionário de 1817, obteria o grau de doutor em Teologia pela Universidade de Paris somente em 1825, durante seu exílio na França, não possuindo ensino superior durante a Constituinte. Não há registro de que os demais deputados (10) tenham concluído algum curso superior. Entre esse grupo, destacam-se os que seguiram a carreira eclesiástica, como os padres Venâncio Henriques de Resende, Manuel Rodrigues da Costa, José Custódio Dias, Antonio Rocha Franco e Silvestre Álvares da Silva. Provavelmente aprenderem as primeiras letras e lições de teologia, história, geografia, retórica e filosofia em seminários organizados por ordens religiosas, responsáveis pelo ensino secundário à época.

Seguindo a trilha de José Murilo de Carvalho, Lúcia Neves afirma que o forte regalismo do Marquês de Pombal, que procurou “assegurar o controle do Estado sobre as instituições educacionais" ${ }^{32}$ reformando os estatutos da Universidade de Coimbra, em 1772, acabou por transformar essa instituição em um centro formador de indivíduos aptos a ocupar altos cargos na administração. Com a reforma, a universidade "passou a servir como principal instrumento de homogeneização, em termos de valores e padrões de comportamento dos indivíduos que pertenciam à elite", formando uma verdadeira "ilha de letrados num mar de analfabetos" 33 e perpetuando a cultura política das mitigadas Luzes portuguesas. Cultura política, vale ressaltar, entendida aqui na acepção que lhe dá Serge Berstein:

\footnotetext{
${ }^{31}$ BLAKE, Augusto Vitorino Sacramento. op. cit., vol. 2, p. 327.

32 NEVES, Lúcia M. Bastos Pereira das. op. cit., p. 29.

${ }^{33}$ CARVALHO, José Murilo de. A construção da ordem: a elite política imperial. Brasília: UnB, 1981, p. 51.
} 
Para os historiadores, a noção de cultura política tem uma acepção bem diversa. Por meio de seus estudos empíricos, eles constatam a existência, num dado momento da história, de vários sistemas de representações coerentes, rivais entre si, que determinam a visão que os homens que deles participam têm da sociedade (...) sistemas que motivam e que explicam seus comportamentos políticos. (...) Mas o essencial reside no fato de que, num dado momento da história, uma cultura política constitui um todo homogêneo cujos elementos são interdependentes e cuja apreensão permite perceber o sentido dos acontecimentos em sua complexidade, graças à visão de mundo das pessoas que compartilham essa cultura. ${ }^{34}$

Trata-se, portanto, de uma construção histórica que "se adapta e se transforma em sintonia tanto com os acontecimentos quanto com as atitudes dos indivíduos e dos grupos, cujos objetivos, por sua vez, ela define" ${ }^{\text {35 }}$. Nesse sentido, os membros das elites políticas partilhavam uma cultura política comum, mais ou menos articulada, cujo objetivo principal era acabar com os entraves coloniais impostos pela metrópole, reconhecendo a tangibilidade da nação ${ }^{36}$, "quer entendida, em um primeiro momento, como 'nação portuguesa', quer referida a uma nova comunidade nacional emergente" ${ }^{37}$, sem, contudo, abalar totalmente as estruturas vigentes, nomeadamente a monarquia e a Igreja. Essa cultura política estava sendo forjada desde a administração pombalina, ganhando fôlego com a reforma da Universidade de Coimbra, em 1772, e com a nomeação de d. Rodrigo de Souza Coutinho ao cargo de Ministro de Estado dos Negócios da Marinha e dos Domínios Ultramarinos, cuja

preocupação fundamental, nascida da experiência da Independência dos Estados Unidos e da Revolução Francesa, tornou-se a de manter, através de criação de um império-luso brasileiro, a colônia do Brasil ligada a Portugal, do qual este seria o centro comercial e aquela, o corpo produtivo, mas em condições de igualdade social com a metrópole e liberdade, enfim, da maior parte dos entraves característicos do sistema colonial. $^{38}$

D. Rodrigo Coutinho reuniria a sua volta um círculo de intelectuais brasileiros, que passaram a desempenhar funções públicas para o Estado português, cujo exemplo

\footnotetext{
${ }^{34}$ BERNSTEIN, Serge. "Culturas políticas e historiografia”. In: AZEVEDO, Cecília [et al.] (orgs.). Cultura política, memória e historiografia. Rio de Janeiro: Editora FGV, 2009, p. 32-33.

${ }^{35}$ NEVES, Lúcia M. Bastos Pereira das. op. cit., p. 25.

${ }^{36}$ OLIVEIRA, Cecília Helena L. de Salles. "Estado, nação e escrita da História: propostas para debate". In: CARVALHO, José Murilo de; NEVES, Lúcia M. Bastos Pereira das. Repensando o Brasil do Oitocentos: cidadania, política e liberdade. Rio de Janeiro: Civilização Brasileira, 2009, p. 241-265.

${ }^{37}$ Ibidem, p. 241.

${ }^{38}$ NEVES, Lúcia M. Bastos Pereira das. op. cit., p. 31.
} 
máximo será José Bonifácio. Esses intelectuais, egressos de Coimbra e imbuídos do espírito de reformas pombalinas, buscaram aplicar a disseminação das ideias ilustradas no cotidiano da colônia, dando vida ao caráter pragmático da ilustração brasileira, estudado por Maria Odila Dias ${ }^{39}$. Assim, foram encomendados pela Coroa inúmeros relatórios sobre os processos empregados no preparo e cultivo dos gêneros exportáveis, levantamentos de plantas nativas a serem remetidas para o Reino, explorações mineralógicas pelo território brasileiro, além da distribuição de prêmios aos lavradores mais industriosos e àqueles que promovessem a introdução do arado e se dedicassem à cultura de novos gêneros na colônia, para citar alguns exemplos ${ }^{40}$.

O despertar da preocupação com a realidade social brasileira é um fruto da ilustração da época, e o processo do seu desenvolvimento torna-se inclusive mais claro quando estudado nesse panorama mais amplo: principalmente se procurarmos suas origens nos trabalhos práticos e nos estudos pragmáticos dos brasileiros dos fins do século XVIII, em que parece evoluir de forma mais diretamente relacionada com a realidade do mundo que tentavam transformar. ${ }^{41}$

A finalidade desses estudos era, ao mesmo tempo, buscar alternativas para a crise econômica vivida pela metrópole, que enfrentava as oscilações do preço do açúcar internacionalmente e o esgotamento do ciclo do ouro, e reformar as estruturas coloniais a fim de evitar novos movimentos sediciosos. As recentes revoluções na França e em Santo Domingos atormentavam as autoridades portuguesas; a solução encontrada por $d$. Rodrigo Coutinho era a construção de um Império luso-brasileiro composto por diversas províncias, "condecoradas com as mesmas honras e privilégios... Todas reunidas ao mesmo sistema administrativo, todas estabelecidas para contribuir para a mútua e recíproca defesa da monarquia" 42 . Para tanto, assegurava aos membros das elites políticas brasileiras que tomassem parte na Ilustração portuguesa, melhorando a condição geral da colônia, sem, contudo, abalar as estruturas vigentes da monarquia e o ideal de Império luso-brasileiro.

As ideias de seu braintrust luso-brasileiro ficaram bastante evidentes no plano de Império proposto pelo secretário de Estado. (...) D. Rodrigo percebeu mais agudamente que a maior parte dos demais a oportunidade oferecida pelas circunstâncias, e discerniu (...) entre a necessidade de reformas esclarecidas e os

\footnotetext{
${ }^{39}$ DIAS, Maria Odila Leite da Silva. “Aspectos da ilustração...”. op. cit., p. 39-126.

${ }^{40}$ Ibidem, p. 56-58.

${ }^{41}$ Ibidem, p. 77.

${ }^{42}$ Apud MAXWELL, Kenneth. “A geração de 1790...”. op. cit., p. 185.
} 
perigos colocados pelas palavras de ordem revolucionárias da Revolução Francesa. ${ }^{43}$

Nesse sentido, as elites políticas foram formadas e aprenderam pragmaticamente que o meio para atingir seus objetivos consistia na adoção de medidas reformadoras de caráter militar, técnico, educacional e administrativo - jamais revolucionário. É por isso que a partir da vinda da Família Real, fundam-se a Academia da Marinha (1808) e a Academia Real Militar (1810), dedicadas à formação de oficiais para a defesa militar da colônia, além dos cursos de medicina (1810) na Corte, e de economia (1808) e agricultura (1817) na Bahia, juntamente com a instalação da Biblioteca Nacional, da Imprensa Régia e do Jardim Botânico no Rio de Janeiro ${ }^{44}$. A Ilustração chegava, enfim, ao Brasil. Porém, esses intelectuais, embora esclarecidos, "não puderam deixar de considerar a religião como um dos esteios do Estado" 45 e por isso mostra-se bastante significativa a fundação do Seminário de Olinda, em 1800, o mais importante dos seminários da época, cuja fundação se deu com o apoio de d. Rodrigo Coutinho:

Por um lado, significava utilizar as Luzes para formar uma elite na colônia capaz de participar de uma aristocracia de mérito, destinada a substituir a nobreza de sangue, mas sem abalar as estruturas vigentes, e habilitada para colaborar, ao mesmo tempo, no projeto do império luso-brasileiro. Por outro, significava recorrer à religião para garantir uma formação mental adequada desses indivíduos, que só poderiam ser "bons cidadãos" se também fossem "bons cristãos" 46 .

É por essa formação inscrita na cultura política da Ilustração portuguesa que se pode afirmar que os membros das elites políticas pós-1820 professavam o liberalismo, e, ao mesmo tempo, não estavam dispostos, porém, a renunciar da condição de súditos de uma nação católica. Muito embora os valores, símbolos e normas dessa cultura política não se expressassem de forma idêntica e única para todos os membros da elite, ocorria um compartilhamento comum dessa visão de mundo, a qual permitia e conciliava a coexistência de antigas e novas formas de pensar e de agir. Na base comum dessa cultura política coexistiam novos elementos, novos discursos e novas ideias com valores, práticas e liturgias típicas do Antigo Regime, como o não abandono da religião católica, entendida

\footnotetext{
${ }^{43}$ MAXWELL, Kenneth. "A geração de 1790...”. op. cit., p. 185-186.

${ }^{44}$ Sobre o assunto, cf. WEREBE, Maria José Garcia. "A Educação". In: HOLANDA, Sérgio Buarque de; CAMPOS, Pedro Moacyr (dirs.). História Geral da Civilização Brasileira. O Brasil Monárquico. Declínio e queda do Império, t. II, v. 4. 2 $2^{\text {a }}$ ed. São Paulo: Difusão Europeia do Livro, 1974, p. 366-383.

${ }^{45}$ NEVES, Lúcia M. Bastos Pereira das. op. cit., p. 32.

${ }^{46}$ Idem.
} 
como o fundamento moral da sociedade brasileira, indispensável à conservação da mesma, e a solução monárquica, ainda que sob os cuidados de uma família real portuguesa.

Ainda sobre a formação dos deputados, outro aspecto analisado foram os cursos escolhidos, intimamente ligados à carreira que acabaram seguindo, como se pode observar nas tabelas 4 e 5 , expostas abaixo:

\begin{tabular}{|c|c|c|c|c|c|}
\hline \multirow{2}{*}{ Nome } & \multicolumn{5}{|c|}{ Cursos } \\
\hline & \begin{tabular}{|l|} 
Cânones \\
\end{tabular} & Engenharia Militar & Filosofia & Leis & Não especificado \\
\hline Antonio Carlos Ribeiro de Andrada Machado e Silva & & & & $\mathrm{X}$ & \\
\hline Antonio da Rocha Franco & & & & & $\mathrm{X}$ \\
\hline Bispo Capelão-Mor & $\mathrm{X}$ & & & & \\
\hline Caetano Maria Lopes Gama & & & & $\mathrm{X}$ & \\
\hline \begin{tabular}{|l|} 
Felisberto Caldeira Brant Pontes \\
\end{tabular} & & $\mathrm{X}$ & & & \\
\hline Francisco Carneiro de Campos & & & & $\mathrm{X}$ & \\
\hline Francisco de Paula Souza e Mello & & & & & $\mathrm{X}$ \\
\hline Francisco Gê Acayaba de Montesuma & & & & $\mathrm{X}$ & \\
\hline Francisco Muniz Tavares & & & & & $\mathrm{X}$ \\
\hline João Evangelista de Faria Lobato & & & & $\mathrm{X}$ & \\
\hline João Severiano Maciel da Costa & $\mathrm{X}$ & & & $\mathrm{X}$ & \\
\hline Joaquim Manuel Carneiro da Cunha & & & & & $\mathrm{X}$ \\
\hline José Custódio Dias & & & & & $\mathrm{X}$ \\
\hline José da Silva Lisboa & $\mathrm{X}$ & & $\mathrm{X}$ & & \\
\hline José Joaquim Carneiro de Campos & & & & $\mathrm{X}$ & \\
\hline José Ricardo da Costa Aguiar & & & & $\mathrm{X}$ & \\
\hline José Teixeira de Fonseca Vasconcelos & & & $\mathrm{X}$ & $\mathrm{X}$ & \\
\hline Luís José de Carvalho e Mello & & & & $\mathrm{X}$ & \\
\hline \begin{tabular}{|l|} 
Manoel Joaquim de Ornellas \\
\end{tabular} & & & & & $\mathrm{X}$ \\
\hline Manoel José de Souza França & & & & & $\mathrm{X}$ \\
\hline Manuel Caetano de Almeida e Albuquerque & & & & $\mathrm{X}$ & \\
\hline Manuel Rodrigues da Costa & & & & & $\mathrm{X}$ \\
\hline Nicolau Pereira de Campos Vergueiro & & & & $\mathrm{X}$ & \\
\hline Silvestre Álvares da Silva & & & & & $\mathrm{X}$ \\
\hline Venâncio Henriques de Resende & & & & & $X$ \\
\hline Total & 3 & 1 & 2 & 12 & 10 \\
\hline
\end{tabular}

\begin{tabular}{|l|r|}
\hline \multicolumn{2}{|c|}{ Tabela 5 - Ocupação profissional dos deputados } \\
\hline Profissão & \multicolumn{1}{|c|}{ o } \\
\hline Clérigo & 7 \\
\hline Magistrado & 14 \\
\hline Militar & 1 \\
\hline Professor & 1 \\
\hline Não identificado & 2 \\
\hline Total & $\mathbf{2 5}$ \\
\hline
\end{tabular}

Chama atenção a predominância do curso de direito, escolhido por 14 deputados, seja em Cânones (dois) ou Leis (12), este último equivalente ao direito civil. A graduação em direito era a preferida dos membros da elite política porque abria oportunidades de 
emprego na estrutura administrativa da colônia. $\mathrm{O}$ segundo curso mais procurado entre os deputados era o de filosofia, tendo sido concluído por José da Silva Lisboa e por José Teixeira de Fonseca Vasconcelos, ambos também graduados em direito - o primeiro em Cânones e o segundo em Leis.

Muitos bacharéis em direito trilharam a magistratura, ocupando cargos de ouvidor, juiz de fora, juiz do crime, juiz de órfãos, intendente, desembargador e, eventualmente, ministro da Justiça, da Fazenda ou dos Negócios e Estrangeiros. Francisco Carneiro de Campos, por exemplo, que se matriculou na Faculdade de Leis da Universidade de Coimbra em 1790, ingressaria na magistratura como ouvidor da comarca de Porto Seguro, sendo em seguida designado juiz de órfãos da cidade da Bahia. Em 1821 seria nomeado intendente do ouro e desembargador da relação da Bahia, cargo que não pôde exercer em razão dos acontecimentos que se desenrolaram naquela província, tomada pelas tropas do general Madeira; assumiria, um ano depois, como secretário da Junta Provisória da Bahia. Em decreto de 5 de março de 1823, d. Pedro o enviaria para o Rio de Janeiro para que tomasse assento na Casa da Suplicação e assumisse como desembargador de Agravos. Em 1830 assumiria a pasta de Negócios e Estrangeiros, e em 1835 tornar-se-ia ministro do Supremo Tribunal de Justiça. Além do mais, seria eleito senador pela Bahia desde a primeira legislatura $(1826)^{47}$. Semelhante seria a trajetória de outros magistrados que tomaram parte na discussão da liberdade religiosa na Constituinte, como, por exemplo, Antonio Carlos, Costa Aguiar e Maciel da Costa.

Entre os sete clérigos envolvidos no debate, havia um bispo (José Caetano da Silva Coutinho, natural de Caldas da Rainha, Portugal), um futuro monsenhor (Francisco Muniz Tavares) e cinco padres. É digna de nota a grande presença de membros do clero não só no debate sobre a liberdade religiosa, mas na Constituinte como um todo: em um universo total de 84 constituintes, 22 (ou 26\%) eram clérigos. ${ }^{48} \mathrm{O}$ expressivo número de padres eleitos como deputados constituintes é significativo da importância desses indivíduos para a sociedade brasileira do Oitocentos. As próprias eleições, vale ressaltar,

\footnotetext{
${ }^{47}$ Informações disponíveis em: http://www.stf.jus.br/portal/ministro/verMinistro.asp?periodo=stj\&id=259. Acesso: 05/03/2016.

${ }^{48}$ Lista de clérigos eleitos para a Assembleia Constituinte de 1823: José Antônio Caldas (Alagoas); Francisco Agostinho Gomes (Bahia); José Martiniano de Alencar, José Joaquim Xavier Sobreira e Manuel Ribeiro Bessa de Holanda Cavalcanti (Ceará); Silvestre Álvares da Silva (Goiás); Belchior Pinheiro de Oliveira, Manuel Rodrigues da Costa, José Custódio Dias, José de Abreu e Silva, Francisco Pereira de Santa Apolônia e Antônio da Rocha Franco (Minas Gerais); José Ferreira Nobre (Paraíba); Francisco Muniz Tavares, Inácio de Almeida Fontana, Francisco Ferreira Barreto, Venâncio Henriques de Resende e Luís Inácio de Andrada Lima (Pernambuco); Bispo Capelão-Mor, d. João Caetano da Silva Coutinho (Rio de Janeiro). Cf. PIRES, Heliodoro. Temas de História Eclesiástica do Brasil. São Paulo: São Paulo Editora S/A, 1946, p. 360.
} 
eram realizadas no interior das paróquias, e sem dúvida o clero nacional possuía, como apontaram João Fagundes Hauck ${ }^{49}$ e Emília Viotti da $\operatorname{Costa}^{50}$, uma consciência política bastante apurada, envolvendo-se fortemente em revoluções e conspirações nacionais não por acaso, a Revolução de 1817 é chamada "Revolução dos padres".

Seguindo a carreira eclesiástica, os clérigos geralmente ocupavam os cargos de presbíteros seculares, vigários, capelões e/ou cônegos. Muniz Tavares seria enviado para Roma entre 1826 e 1832, encarregado de conduzir o reconhecimento do Padroado Régio na figura de d. Pedro e da Independência do Brasil pela Santa Sé. Já o único militar envolvido no debate seria o marechal Felisberto Caldeira Brant Pontes, também senador, eleito por três províncias, Bahia, Minas Gerais e Alagoas, sendo nomeado pela última, chegando a ocupar brevemente a pasta da Fazenda em 1829 ${ }^{51}$. Quanto ao único professor da lista, trata-se de José da Silva Lisboa, futuro visconde de Cairu. Graças a sua vasta erudição, Lisboa seria professor régio, além de ocupar o cargo de desembargador do Paço e de censor da Imprensa Régia. Eleito senador pela Bahia na primeira legislatura, editaria alguns periódicos, como $O$ Conciliador (1821) e Sabatina Familiar dos amigos do bem comum (1821-1822), e publicaria livros sobre História do Brasil ${ }^{52}$.

Analisando os dados contidos nas tabelas acima, não há dúvidas de que os deputados constituintes envolvidos no debate da liberdade religiosa integravam as elites políticas da época. Além de possuírem uma formação baseada no reformismo ilustrado de Pombal e de d. Rodrigo Coutinho, de caráter pragmático e avesso aos excessos revolucionários - que faz com que mesmo os liberais mais radicais primassem pela ordem e tranquilidade públicas e por uma "bem entendida liberdade" -, estavam inseridos na administração pública desde o governo joanino, pelo menos aqueles cuja ocupação era a magistratura. Homens que haviam presenciado os movimentos sediciosos de fins do século XVIII e que haviam reconhecido a tangibilidade da nação, primeiramente inserida na noção de Império luso-brasileiro, logo em seguida reconhecida como uma comunidade nacional emergente, da qual eram os legítimos representantes eleitos.

\section{Os debates}

\footnotetext{
${ }^{49}$ HAUCK, João Fagundes. "Quarto período: a Igreja na emancipação (1808-1840)". In: et al. História da Igreja no Brasil. Ensaio de interpretação a partir do povo. Segunda Época: A Igreja no Brasil no século XIX. Petrópolis: Editora Vozes, 1980.

${ }^{50}$ COSTA, Emília Viotti da. Da Monarquia à República: momentos decisivos. $9^{\text {a }}$ ed. São Paulo: UNESP, 2010.

${ }^{51}$ BLAKE, Augusto Vitorino Sacramento. op. cit., vol. 2, p. 327.

${ }^{52}$ BLAKE, Augusto Vitorino Sacramento. op. cit., vol. 5, p. 193-203.
} 
Foi na sessão de 7 de outubro de 1823, sob a presidência de Martim Francisco Ribeiro de Andrada, que o artigo $7^{\circ}$ do projeto de Constituição entrou para a ordem do dia, concebido nos seguintes termos: "A Constituição garante a todos os Brasileiros os seguintes direitos individuais, com as explicações e modificações anexas" ${ }^{53}$. Assim que o presidente leu o $\S 1^{\circ}$ do artigo, "A liberdade pessoal”, o mineiro Maciel da Costa criticou que se enumerassem os direitos individuais para só depois explicá-los e limitá-los em artigos subsequentes. Sua posição foi apoiada por outros oradores, como Manoel de Souza França e o padre Henriques de Resende. Maciel da Costa, futuro redator da Constituição de 1824 , considerava necessário, já no artigo $7^{\circ}$, que aos direitos se seguisse uma breve descrição ou definição de seus termos, pois acreditava ser importante

fixar com clareza no espírito dos Povos, que pela maior parte não têm instrução, uma ideia clara do que eles devem entender por liberdade pessoal, a fim de poderem defendê-la, trazendo-a sempre na memória, assim contra os ataques de seus concidadãos como das autoridades, quando elas passarem de tutelares a opressoras. ${ }^{54}$

Já para Manoel de Souza França, a enumeração dos direitos era adequada a obras didáticas, mas dispensáveis em uma Constituição, podendo inclusive ser prejudicial, porque "se pode daí concluir que somente esses direitos individuais hão de ser guardados,

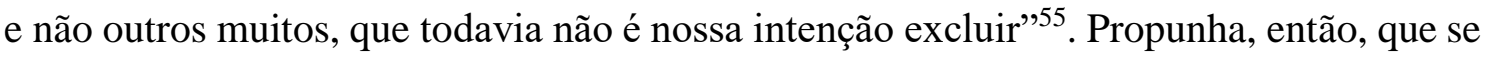
suprimisse todo o artigo $7^{\circ}$, o que não foi apoiado pela Assembleia. Antonio Carlos de Andrada Machado, principal redator do projeto, defenderia o artigo, afirmando que as definições aos direitos individuais se faziam desnecessárias, uma vez que "toda a pessoa entendia o que era liberdade pessoal". Além do mais, para o deputado, "quando se definiam coisas de si claras, ordinariamente se escureciam ao invés de se iluminarem" 56 .

Consultada a Assembleia, a emenda de Manoel de Souza França foi rejeitada e os $\S \S 1^{\mathrm{o}}$ e $2^{\mathrm{o}}$, que versavam sobre a liberdade pessoal e o juízo de jurados, foram aprovados sem alterações. Em seguida, passou-se para o $\S 3^{\circ}$, “A liberdade religiosa”, tendo início o segundo maior debate da Assembleia acerca dos artigos constitucionais. O primeiro a se manifestar sobre a matéria foi, novamente, Antonio Carlos. Para o constituinte, a liberdade religiosa era a "liberdade de adorar cada um o Ente Supremo pela forma que

\footnotetext{
${ }^{53}$ Diário da Assembleia Geral, Legislativa e Constituinte..., op. cit., t. III, p. 183.

${ }^{54}$ Idem.

${ }^{55}$ Ibidem, p. 184.

${ }^{56}$ Idem. Por falar com bastante rapidez, muitas vezes os taquígrafos não conseguiam acompanhar o discurso de Antonio Carlos, sendo comum transcreverem um pequeno resumo de sua fala.
} 
melhor lhe parece". "Este direito é tão sagrado", continuava ele, "que eu creio nem deveria entrar no catálogo dos direitos garantidos porque a relação da criatura com o criador está fora do alcance político" 57 . Deixava claro, portanto, logo em sua primeira fala, ser favorável à liberdade de culto por tratar-se de uma escolha íntima e consciente de cada indivíduo, sobre a qual a sociedade não pode intervir:

Quando os homens se ajuntaram, e por convenção sacrificaram uma porção de sua liberdade para conservar a outra, seguramente não cederam do direito de adorar a Deus do modo que lhes parecesse melhor, para se sujeitaram à forma que lhes fosse determinada. Porém, uma vez que a Sociedade chegou a essa desgraça, uma vez que até se tem usurpado o domínio do pensamento, é preciso com cuidado estabelecer este direito. Por isso a Comissão declarou a sua garantia, para evitar o absurdo de se obrigar o cidadão a praticar o contrário do que lhe dita a sua consciência, em negócio de que não tem poder a Sociedade, e de que ninguém deve pedir contas. ${ }^{58}$

O padre e constituinte Henriques de Resende se manifestaria criticando, tal como já haviam feito Maciel da Costa e Manoel França, a disposição dos artigos, visto que a todos os direitos elencados no artigo $7^{\circ}$ cabiam exceções e limites. Mas, “como já passaram os $\S \S 1^{\circ}$ e $2^{\circ}$, , concordava que se fizesse o mesmo com o $\S 3^{\circ}$, ponderando que "no estado atual do Brasil, é preciso apresentar aos Povos logo a princípio essas garantias assim mesmo genericamente concebidas", para só depois declarar "os termos e limites desta liberdade", bem como "as exceções necessárias" 59 . É importante frisar que os artigos 14, 15 e 16 também versavam sobre a liberdade religiosa, limitando-a às comunhões cristãs e concebendo direitos políticos apenas àqueles que professassem tais comunhões (art. 14), determinando que as demais seitas religiosas fossem apenas toleradas (art. 15) e especificando que a religião católica era a religião oficial do Império e a única mantida por ele (art. 16). Ou seja, tratava-se, no projeto de Constituição, de uma razoável liberdade de culto, que somente tolerava as demais religiões, cujos praticantes não poderiam gozar de direitos políticos, e que convivia com um credo oficial, mantido pelo Estado.

Maciel da Costa, depois de posicionar-se contrário à forma de exposição do artigo, toma a palavra novamente para criticar o conteúdo do $\S$. Para o representante mineiro, afiançar que a liberdade religiosa é um direito individual dos brasileiros equivale a

\footnotetext{
${ }^{57}$ Ibidem, p. 185.

${ }^{58}$ Idem.

${ }^{59}$ Idem.
} 
ofender o culto nacional. Só aceitava a liberdade de culto para os "homens úteis ao nosso Império", ou seja, para os estrangeiros, mas jamais para os brasileiros, que têm "a felicidade de não contar no seio de sua grande família nem uma só Seita das infinitas que há de Protestantes, e que por condição essencial sine qua non de seu pacto social jura manter a Religião Católica Apostólica Romana"60.

Para quem legislamos nós? Para Brasileiros, isto é, para Católicos Romanos. (...) E para quê? Para decretarmos que nós, eles, nossos filhos, nossa posteridade teremos o direito de apostatar da verdadeira Religião, da Religião de nossos gloriosos maiores? Não, Sr. Presidente, não. (...) Mas os Brasileiros, animados de princípios liberais e generosos, não querem excluir de seu seio homens úteis a nosso Império nascente, só porque eles não são católicos, venham esses estrangeiros, e serão nossos irmãos, seja qual for a sua crença. ${ }^{61}$

Percebe-se na fala de Maciel da Costa um princípio que será defendido por vários deputados, qual seja, a do caráter utilitário e pragmático da liberdade religiosa. Na visão desses constituintes, admitia-se a liberdade de culto mais para atrair estrangeiros para o Brasil - úteis tanto para o povoamento de seu vasto território, quanto para substituir gradativamente a mão de obra escrava -, do que para atender propriamente a uma demanda dos brasileiros. Vale ressaltar, como veremos adiante, que havia uma preocupação dos parlamentares em garantir condições jurídicas favoráveis aos protestantes ingleses que residiam ou que viessem a residir no país, sobretudo devido às fortes relações "de amizade e comércio" que mantinham com a Inglaterra.

Ainda com relação aos estrangeiros - únicos que, na grande família da nação da brasileira, não eram católicos, segundo o deputado -, Maciel da Costa afirmou que "tudo que nós podemos fazer nesse negócio é não consentir que o Cidadão seja perseguido por suas opiniões religiosas, enquanto ele as não espalhar ou pregar de um modo sedicioso", bem como não permitir que "o Cidadão seja espionado até no interior de sua família para saber o Governo suas ideias". "Feito isso", finalizava o deputado, "temos Liberdade Religiosa (...), a única de que necessitamos, a única que nos pode ser útil” ${ }^{\prime 2}$. Apesar de ter dado a hora das indicações, e do presidente ter adiado a discussão para a próxima sessão, a fala do deputado mineiro acenderá grande polêmica, ressoando em outros discursos. O fato de ter acusado a comissão de declarar, com o artigo, a apostasia, ou seja,

\footnotetext{
${ }^{60}$ Idem.

${ }^{61}$ Ibidem, p. 186.

${ }^{62}$ Idem.
} 
o ato de renunciar a uma religião ou crença, de abandonar sua fé, será retomado mais adiante, assim como a questão de perseguições a praticantes de outras religiões.

Na sessão seguinte, aos 8 de outubro, o padre e representante de Minas Gerais, Manuel Rodrigues da Costa, prosseguiria o debate, apresentando uma posição muito próxima de seu conterrâneo Maciel da Costa. Afirmaria, em primeiro lugar, que na sessão anterior ouvira proposições que muito o escandalizaram: "Ouvi que era livre ao homem adorar a Deus no seu coração, como bem lhe parecesse, e que também o podia adorar com o culto que melhor the agradasse". Escandalizava-se porque a nação brasileira possuía uma "Religião Revelada, pela qual Deus nos fez conhecer como o devemos adorar, tanto interior como externamente (...) e, portanto, não nos resta mais essa liberdade" ${ }^{63}$. Em longo discurso, retomaria a questão da apostasia, afirmando que "não há Religião nenhuma onde a apostasia não seja crime", requerendo que "não passe, mas seja excluído semelhante Artigo" a fim de "não ser perjuro ao juramento que temos prestado de manter e defender a Religião Católica Romana"64.

O cônego da Capela Imperial temia que, caso fosse aprovada a liberdade religiosa, levantar-se-iam "Altar contra Altar dentro da mesma Nação, uns seguiríamos as máximas que nos ensinam os Santos Evangelhos de Jesus Cristo, e outros os perversos dogmas de Calvino, de Lutero (...) que se quiseram erigir em reformadores". Considerava tal artigo um verdadeiro "escândalo para Povos Cristãos", especialmente para a nação brasileira, que "tem sempre sustentado em toda a sua pureza a Religião Católica Romana"65:

\footnotetext{
Quando a Nação nos elegeu para seus Representantes, e depositou nas nossas mãos a sua autoridade, foi na consideração de que não só sustentaríamos os seus direitos, mas que faríamos a sua felicidade; não foi certamente para lhe darmos o que tanto repugnam com os seus sentimentos, princípios e deveres. ${ }^{66}$
}

Francisco Muniz Tavares, também padre, opõe-se a Rodrigues da Costa em seu discurso. Apesar do passado revolucionário dos dois - o primeiro havia participado da Revolução de 1817 e o segundo da Inconfidência Mineira -, os dois representantes do clero divergiam completamente acerca da matéria do artigo. Rodrigues da Costa, o mais velho dos constituintes envolvidos no debate, no auge de seus 69 anos, mostra-se escandalizado com a proposição da liberdade religiosa. Muniz Tavares, por sua vez,

\footnotetext{
${ }^{63}$ Ibidem, p. 189.

${ }^{64}$ Ibidem, p, 190.

65 Idem.

66 Idem.
} 
temendo principalmente perseguições e intolerância religiosa, vota pela aprovação do artigo. O pernambucano inicia sua fala citando Montesquieu - "aqui sou político, não sou Teólogo" -, dando indícios de sua postura, por assim dizer, pouco ortodoxa, para em seguida expor a sua opinião, já que

graças a Deus não estamos nesses tempos de estupidez em que o Monge São Bernardo prometia ao Sr. de Chantillon em troca do imenso terreno, que lhe dava para a fundação da Abadia de Ligni, um espaço de igual extensão no Paraíso; como já ninguém receia ser queimado vivo, como herege, ou heterodoxo, por discordar da opinião de Teólogos, não devo eu igualmente recear de dizer francamente a minha opinião sobre tão importante matéria. ${ }^{67}$

Continuava, contrapondo diretamente Rodrigues da Costa: “Apesar de tudo quanto acaba de dizer o Nobre deputado, eu reputo, e reputarei sempre a Liberdade Religiosa um dos Direitos mais sagrados que pode ter o homem em Sociedade". O antigo companheiro de prisão de Antonio Carlos concordava com o redator do projeto ao afirmar que, para ele, "a consciência é um santuário, onde poder nenhum humano tem poder de penetrar". Assegurava, como membro do clero, que seguia unicamente a religião católica, tendo "por princípios que ela é a única verdadeira", porém, não desejaria ser perseguido e/ou inquietado caso praticasse outro culto:

Nasci no grêmio dessa Religião, e pretendo, mediante os auxílios da Divina Graça, nela viver, e morrer; mas se por desventura (o que Deus não permita), a Graça me abandonar (...) e eu passar a seguir outra Religião, não desejarei ser perseguido, nem inquietado no exercício dessa Religião adotada, e persuado-me que o Nobre deputado, que acaba de falar, também não gostaria de ser perseguido. Isto posto, como poderei jamais deixar de aprovar este artigo? ${ }^{68}$

Em seu discurso, Muniz Tavares citou "déspotas estúpidos e mal intencionados" que, a fim de promoverem a sua crença, optaram por perseguir seus súditos, gerando intolerância religiosa, que, por sua vez, provocou resistência a seus governos. "Há no homem um princípio de revolta contra todo o constrangimento intelectual; este princípio pode degenerar em furor, pode ser causa de grandes crimes" 69 . Afirmaria também que "o Deus a quem adoro, Deus do amor, e Pai dos homens (...) não quer ser adorado à força", como era prática nos tempos do "hórrido Tribunal, chamado por insolência de Santo

\footnotetext{
${ }^{67}$ Idem.

68 Idem.

${ }^{69}$ Idem.
} 


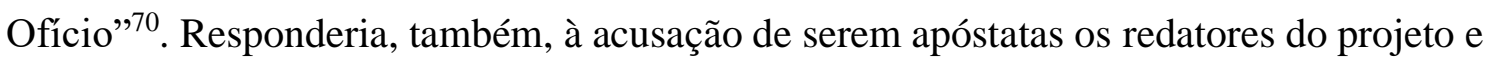
os defensores do artigo, criticando os deputados que se valeram dessa insinuação:

Como é que se pode jamais concluir, que sancionando nós o Artigo, sancionamos a Apostasia? Dizemos nós por ventura que o Governo deixará de proteger a Religião Católica, que aqueles que a professarem serão inibidos dos Direitos Civis e Políticos? (...) Semelhante procedimento não passou pela cabeça de nenhum dos Srs. Deputados, Redatores deste Projeto. Pelo contrário, eles dizem mui positivamente que a Religião do Estado, a Religião por excelência, é a Católica Romana. ${ }^{71}$

Aliás, para o futuro monsenhor, o fato de a Constituição instituir a religião católica como credo oficial era, na verdade, "um favor, e favor muito especial, talvez condenado pelos princípios de mui sã política, por ter tantas vezes a preferência dada a uma Religião sobre as outras acarretado perturbações aos Estados". Finalmente, questionaria: “Como é, pois, (...) que à vista de um tal favor se pode ainda tirar por conclusão que sancionamos a Apostasia?" 72 .

O veterano Rodrigues da Costa pede a palavra para defender-se, afirmando ter sido mal interpretado por Muniz Tavares. Segundo o deputado, seu voto contrário ao parágrafo não equivalia a defender que "aqueles que apostatassem da Religião fossem perseguidos a ferro e a fogo, segundo o sistema antigo". Garantia estar "bem persuadido que nenhum homem pode obrigar outro a exercer aquilo que ele não acreditar", uma vez que a "fé é uma Graça de Deus", sendo os ministros e pastores da Igreja responsáveis por “sustentar no seu rebanho a pureza da Religião, e da sua crença”. Mantinha o seu veto por acreditar que a liberdade religiosa iria “embaraçar o zelo dos Pastores da Igreja, em vez de o auxiliar, como é nosso dever" ${ }^{\prime 73}$. Nesse sentido, para o deputado mineiro, não havia separação entre os negócios da Igreja e do Estado, de forma que um deveria assistir o outro.

O padre Henriques de Resende tornaria a falar, desta vez criticando o discurso de Rodrigues da Costa e posicionando-se a favor de uma razoável liberdade religiosa. Primeiramente, acusaria Rodrigues da Costa de defender a "perfeita intolerância", fruto de seu excesso de zelo - o qual chama de "acre, intolerante e inquisitorial" - em manter o juramento que havia prestado. Tal zelo causaria "mais males do que bens ao

\footnotetext{
${ }^{70}$ Ibidem, p. 191.

${ }^{71}$ Idem.

72 Idem.

${ }^{73}$ Idem, grifo nosso.
} 
Catolicismo", que teria "adquirido muito mais filhos e outros se não teriam segregado de seu seio, se os Ministros do Culto tivessem sido tolerantes". Relembraria o cisma da Inglaterra com a Igreja Católica, chegando inclusive a responsabilizar as "pretensões dos Legados Apostólicos e dos Papas" ${ }^{, 74}$ pelo episódio:

A intolerância tem feito imensos males. Não foi Henrique VIII quem separou a Inglaterra do grêmio da Comunhão Romana, foram as pretensões dos Legados Apostólicos e dos Papas: foi a sua intolerância, que tanto havia indisposto aqueles Povos, de sorte que Henrique VIII não fez senão aproveitar-se dessa indisposição. E tal era o ódio, que sendo ali admitidas muitas seitas, a Católica tem sido banida por causa da sua intolerância. ${ }^{75}$

Observa-se no embate entre os padres Henriques de Resende, Muniz Tavares e Rodrigues da Costa que os dois primeiros representariam a heterodoxia do clero brasileiro, mais engajados com uma religião de Estado do que com a própria Igreja e com Roma. Antes funcionários públicos do que membros do clero, não defendiam na primeira Assembleia Constituinte do Brasil as prerrogativas espirituais ante o poder temporal do Estado, além de assumirem uma postura bastante crítica com relação aos abusos da Igreja. Para o padre João Fagundes Hauck, autor de História da Igreja no Brasil, obra de 1980, a consciência do clero durante a emancipação do país

não é adequada para dar-nos uma ideia da Igreja brasileira; eram funcionários de uma religião de Estado agressivamente única (...) Por parte das autoridades civis era tão abrangente o conceito de padroado que nem se pode falar de Igreja como instituição distinta do poder absoluto do Estado, que absorvia a religião como uma de suas instituições fundamentais. ${ }^{76}$

Já Rodrigues da Costa seria o que Roque Spencer Barros chamou de "um dos poucos campeões da religião romana dispostos a fazer valer no país o catolicismo em sua integridade, para tanto invocando o caráter oficial de sua crença"77. Seria apoiado não por outros membros do clero, mas por deputados que viam na religião católica o fundamento moral da sociedade, nomeadamente Maciel da Costa e Silva Lisboa. Esses homens escandalizavam-se com a possibilidade de se permitir aos brasileiros que abandonassem

\footnotetext{
${ }^{74}$ Ibidem, p. 192.

75 Idem.

${ }^{76}$ HAUCK, João Fagundes. “Quarto período: a Igreja na emancipação...”. op. cit., p. 15.

${ }^{77}$ BARROS, Roque Spencer M. de. "Vida religiosa”. In: HOLANDA, Sérgio Buarque de; CAMPOS, Pedro Moacyr (dirs.). História Geral da Civilização Brasileira. O Brasil Monárquico. Declínio e queda do Império, t. II, v. 4. 2a ed. São Paulo: Difusão Europeia do Livro, 1974, p. 324.
} 
a fé católica, sobretudo porque consideravam que a nação era formada inteiramente por católicos, não sendo uma necessidade ou demanda instituir-se a liberdade religiosa.

Ao finalizar seu discurso, Henriques de Resende mandaria à Mesa uma emenda ao parágrafo. Ciente de que "os inimigos dos princípios liberais" questionariam qualquer decisão da Assembleia no sentido de permitir a liberdade religiosa, o padre considerava mais prudente alterar a redação do parágrafo para uma "razoável liberdade religiosa", pois "os Povos facilmente abraçarão este princípio assim enunciado"78:

os inimigos dos princípios liberais nos espiam; eles lançarão mão de qualquer palavra, de qualquer decisão da Assembleia a este respeito, para irem com ela fazer uma fricção violenta nos princípios do Povo, e dirão: são os Carbonários e os PedreirosLivres que querem destruir o Trono e o Altar (...) Passe também esse parágrafo, mas ajuntando-lhe a palavra razoável. Sei que a Assembleia quer que tudo seja razoável, e os Povos facilmente abraçarão este princípio assim enunciado, e nos artigos 14 e 15 faremos as explicações convenientes. ${ }^{79}$

O próximo a envolver-se no debate será José da Silva Lisboa. Embora reconhecesse ser "já quase pó e cinza” e estar "próximo de aparecer ante o Juiz Eterno", tomaria, porém, parte na discussão "pela sua importância e perigosa consequência". Posicionar-se-ia a favor da supressão do parágrafo por considerá-lo "mal soante e de escândalo aos ouvidos pios", capaz de produzir "no espírito do povo uma terrível impressão" de que se estaria concedendo "ilimitada faculdade aos naturais do Brasil de desertarem da Religião de seus Pais, e publicamente seguirem e professarem seitas e heresias de Países estrangeiros" ${ }^{\text {" }}$. Tributário da tradição tridentina e contrarreformista da supremacia de Roma e da Igreja católica, criticaria os redatores do projeto por terem sido imprudentes e por apresentarem, no referido parágrafo, "uma doutrina que tende a abalar nos entendimentos fracos os, antes imóveis, princípios do Catolicismo".

Esquivando-se de ser rotulado como intolerante, deixaria claro que não fazia apologia a nenhum tipo de perseguição ou violência: "Longe de mim inculcar doutrinas antiquadas e absurdas de absoluta intolerância de opiniões". Porém, acreditava ser o parágrafo desnecessário em uma nação a qual "jamais lhe ocorreu até agora a menor

\footnotetext{
${ }^{78}$ Diário da Assembleia Geral, Legislativa e Constituinte..., op. cit., tomo II, p. 192.

${ }^{79}$ Idem.

${ }^{80}$ Idem.
} 
dúvida da verdade e unidade daquela sua Religião" ${ }^{\circ 1}$, especialmente em se tratando de uma religião

que tem sido, e consequentemente é, o nosso conforto e a esperança de felicidade eterna, e que, aliás, por tantos motivos de credibilidade, tem os caracteres da Revelação Divina, havendo por isso feito época nos Anais da Sociedade, que ainda ora se intitula a Era Cristã ; tendo civilizado a tantas Nações, que, antes de receberem a sua doutrina, eram bárbaras e selvagens, continuando a ser tais, ou cheias de desordens civis e políticas, todas aquelas que ou não a tem abraçado, ou só recebido com cismas e divisões arbitrárias, apartando-se do Centro da União, isto é, do Cabeça visível da Igreja Universal, o Sumo Pontífice de Roma. ${ }^{82}$

Percebe-se, portanto, que Silva Lisboa apresenta uma posição antagônica aos padres Henriques de Resende e Muniz Tavares com relação à Roma e à autoridade do Papa. Para estes, a atitude de Roma perante a solicitação do rei da Inglaterra fora bastante desastrosa e demonstrara a intolerância da instituição da Igreja; para aquele, aproximarse do Sumo Pontífice era essencial para evitar desordens civis e políticas e para auxiliar no processo civilizatório de uma nação. O futuro visconde de Cairu continuaria criticando o parágrafo, declarando que liberdade religiosa, nas atuais circunstâncias no Brasil, equivalia à liberdade de perjúrio, pois daria "a cada indivíduo faculdade real, pleno arbítrio na renúncia, escolha e mudança de Religião" ${ }^{83}$ :

Sr. Presidente, no meu humilde entender, Liberdade Religiosa, considerando as circunstâncias do Brasil, vem a ser Liberdade de Perjúrio e Liberdade de Apostasia, pois, havendo todos os Cidadãos Brasileiros jurado guardar a Religião Católica, o declarar-se agora em Constituição que é seu direito individual ter Liberdade Religiosa é o mesmo que declarar-se que pode perjurar e prescindir de seu Juramento, sendo apóstata da Religião em que nasceu e que publicamente tem professado. ${ }^{84}$

O deputado reconhecia que "do meado do Século passado em diante" muitos filósofos haviam escrito sobre "a necessidade de Tolerância em matérias de Religião, ainda nos Países em que há alguma dominante e mantida pelo Governo", chegando até a recomendar que "não houvesse Religião Dominante do Estado, considerando que assim se evitariam as Guerras Religiosas, as perseguições civis, as antipatias nacionais e se

\footnotetext{
${ }^{81}$ Ibidem, p. 193.

${ }^{82}$ Idem.

83 Idem.

${ }^{84}$ Idem.
} 
promoveria a paz". Contudo, "não obstante estas razões plausíveis", prosseguia Silva Lisboa, "os Estadistas se devem regular pela experiência" ${ }^{85}$, nomeadamente pelo exemplo francês da desastrosa tolerância religiosa absoluta:

Principiando-se por declarações contra a Intolerância, requereuse a Tolerância absoluta do Governo sobre objeto Políticos e Religiosos. Os Cabalistas abusaram logo das sucessivas concessões de tolerância, e derrubaram o Governo estabelecido e as suas próprias novas Constituições, aliás cheias de Declarações dos Direitos do Homem, e de liberdades na Administração e Religião, que o Povo Francês (que antes era mui subordinado e Católico) nunca imaginara, nem reclamara. Os Representantes da Nação por fim foram intolerantíssimos de tudo que se opunha às opiniões do partido dominante, e ocasionaram matanças e horribilidades (sic), que nunca houveram em guerras e perseguições Religiosas. ${ }^{86}$

Por fim, retomava o argumento, já explorado por Maciel da Costa e Rodrigues da Costa, acerca das necessidades da nação, afirmando que "todos os prudentes concordam que a melhor Constituição é a que mais se acomoda às circunstâncias do País a que se destina". No Brasil,

nem existe a vasta instrução, que distingue os Países mais civilizados, que serviria de antídoto contra os desvarios dos infiéis, nem há ostensivamente Nacionais que tenham a fatuidade de professarem Luteranismo, Calvinismo, e outras Seitas dissidentes da Religião Católica. Portanto, a concessão de Liberdade Religiosa é uma liberdade pródiga, não solicitada pela Nação (...) nem ainda reclamada por alguma considerável fração dos Cidadãos Brasileiros. ${ }^{87}$

Digno de nota é a forma como os deputados, entre eles Silva Lisboa, referem-se às diferentes religiões. Observa-se uma hierarquia entre elas, uma vez que a grande maioria dos deputados atribui ao catolicismo o status de "religião", aludindo sempre à “religião católica". Já as demais religiões raras vezes são tratadas como tais, atribuindolhes o caráter de "seitas", o que pode indicar uma tentativa de estigmatizar e desprestigiar seus cultos, dogmas e liturgias ante a pureza e a verdade, tantas vezes defendidas pelos constituintes, do catolicismo.

O grande defensor dos direitos civis dos escravos forros, Silva Lisboa, não reconhecia a existência, no país, de religiões de matriz africana, como por exemplo o

\footnotetext{
${ }^{85}$ Ibidem, p. 194.

${ }^{86}$ Idem.

${ }^{87}$ Idem.
} 
Candomblé. Sabemos, porém, que muitos escravos e até mesmo homens e mulheres brancos professavam essa religião. Em meados de 1829, por exemplo, o episódio da invasão do Candomblé de Accú, nos arredores de Salvador, seria significativo da presença da cultura e religião africanas no Brasil. Segundo João José Reis e Eduardo Silva, no início do século XIX espalhavam-se pelas províncias brasileiras diversos terreiros, que causavam temor e preocupação às autoridades, levando à invasão desses espaços. $\mathrm{O}$ testemunho do professor de grego Luis dos Santos Vilhena demonstra esse receio dos brancos, livres e católicos quanto aos terreiros e associações de negros em Salvador:

Não parece ser muito acerto em política o tolerar que pelas ruas e terreiros da cidade façam multidões de negros de um, e de outro sexo, os seus batuques bárbaros a toque de muitos e horrorosos atabaques, dançando desonestamente e cantando canções gentílicas, falando línguas diversas, e isto com alaridos horrendos, e dissonantes que causam medo e estranheza. ${ }^{88}$

Muito provavelmente Silva Lisboa pensasse como o professor Luis Vilhena a respeito das manifestações religiosas africanas, considerando-as apenas "batuques bárbaros" e expressões "gentílicas" e "horrendas", e não uma religião propriamente dita, como a católica e também todas aquelas identificadas como protestantes. Sob esta ótica, faz sentido a declaração tanto de Silva Lisboa, quanto de Maciel da Costa de que os brasileiros não contavam no seio de sua grande família com números expressivos de praticantes de outras comunhões diversas do catolicismo. A introdução do protestantismo no Brasil, por exemplo, ocorreria no início do século XIX, a partir da vinda da Família Real para o país sob a proteção da Inglaterra. Desde então, os Tratados de Aliança e Amizade e de Comércio e Navegação, firmados em 1810, estabeleceram que os "vassalos de Sua Majestade Britânica", residentes nos territórios portugueses, não seriam

perturbados, inquietados, perseguidos, ou molestados por causa de sua religião, mas antes terão perfeita liberdade de consciência e licença para assistirem e celebrarem o serviço divino e honra do Todo-Poderoso Deus, seja dentro de suas casas particulares, quer nas suas igrejas e capelas. ${ }^{89}$

\footnotetext{
${ }^{88}$ Apud REIS, João José; SILVA, Eduardo. Negociação e conflito: a resistência negra no Brasil escravista. São Paulo: Companhia das Letras, 1989, p. 37-38.

${ }^{89}$ Apud FEITOSA, Pedro Barbosa de Souza. "Que venha o Teu Reino": estratégias missionárias para a inserção do protestantismo na sociedade monárquica (1851-1874). Dissertação (Mestrado em História). Universidade de Brasília, Brasília, 2012, p. 19.
} 
As limitações impostas aos ingleses relacionavam-se à "aparência dos templos, que deviam assemelhar-se às casas de habitação", não podendo ter sinos, e ao "proselitismo, visto que não podiam anunciar e fazer propaganda de sua religião aos brasileiros" $" 90$. A partir da Constituição de 1824, porém, o proselitismo deixou de ser proibido, muito embora se mantivessem as restrições aos direitos políticos e à exterioridade dos cultos aos praticantes de seitas acatólicas. Vários entraves eram impostos aos não católicos na Carta Magna e na legislação ordinária, como a proibição à candidatura de cargos públicos, ao sepultamento em cemitérios municipais e ao casamento legal, isto é, conforme as ordenações tridentinas. Nesse contexto, até a segunda metade do século XIX, quando as leis abolicionistas trouxeram à tona a necessidade de se atrair estrangeiros para o país, os protestantes representavam um número muito pouco expressivo da população nacional. Segundo Feitosa,

num primeiro momento (1810-1850), os grupos protestantes existentes no Brasil eram formados, basicamente, por imigrantes vindos de países como Inglaterra, Alemanha e Suíça. Sob aquelas limitações legais e na condição de estrangeiros em uma sociedade ordenada sob o catolicismo oficial, esses grupos não realizaram um trabalho sistemático de anúncio da religião protestante aos brasileiros. ${ }^{91}$

Tal cenário contribuiu para que alguns constituintes se opusessem ao $\S$, acreditando não ser uma demanda necessária da nação naquele momento. Para Silva Lisboa, por exemplo, "uma vez que se introduzisse a Liberdade Religiosa, não se poderia impedir que se formassem Congregações de diversas Seitas, e se erigissem Templos e Cultos públicos com seus particulares rituais e extravagantes Liturgias"92. Desta forma, não faltariam pretextos para os "libertinos dissentirem do Credo estabelecido", e muitos brasileiros render-se-iam à "simplicidade do culto do Povo Inglês", abandonando os dogmas católicos:

Não faltarão $\log$ o entusiastas que persuadissem e procurassem generalizar, por exemplo, a Religião Anglicana, que tanto se louva, como mais favorável ao progresso da Liberdade Política, sã Moralidade e ativa indústria. A consequência seria certa, ou com muito verossimilhança, que, vendo o nosso Povo a simplicidade do culto do Povo Inglês (com quem sempre teremos

\footnotetext{
${ }^{90}$ FEITOSA, Pedro Barbosa de Souza. “Que venha o Teu Reino...”. op. cit., p. 19.

${ }^{91}$ Ibidem, p. 22.

${ }^{92}$ Diário da Assembleia Geral, Legislativa e Constituinte..., op. cit., t. III, p. 194.
} 
as maiores relações comerciais) consideraria mui dispendiosa, e inútil, a mantença da Religião Católica. ${ }^{93}$

Lisboa ressaltava que, entre os católicos praticantes, ocorria o temor de uma vez estabelecida a liberdade religiosa entre os brasileiros, muitos acabariam abandonando a fé cristã, seduzidos pelas "extravagâncias" de outros cultos. Concluiria sua fala afirmando só ser razoável a tolerância religiosa para os estrangeiros, visto que "tanto convém atrair os industriosos e Capitalistas de todas as Nações ao Brasil”, posição igualmente defendida por Maciel da Costa. Não aplicava essa lógica aos brasileiros, pois, "que corretivo lhes restará, havendo tanta falta de instrução das classes inferiores e servis, sem a influência poderosa da Religião Católica?”. E finalizava, profético: “Céus! Que futuro se nos preparam!"94.

Os próximos oradores seriam os irmãos Francisco Carneiro de Campos e José Joaquim Carneiro de Campos, o primeiro representante da Bahia e o segundo do Rio de Janeiro. Para Francisco, o mais velho dos irmãos, o parágrafo não tratava de teologia, mas sim de uma questão puramente política, por ele assim resumida: "deve, ou não, a Constituição garantir a tranquilidade e Liberdade de Cultos Religiosos com as modificações e declarações contidas nos Artigos deste Capítulo?”. Em outras palavras, “deverá qualquer Cidadão ser molestado ou perseguido por motivo de Religião, ainda que professe outra distinta da Religião Católica Romana, que no Artigo 16 se declara ser a Religião do Estado?"95.

Nesses termos, o deputado posicionar-se-ia como favorável à liberdade religiosa, acrescentando estar persuadido de que "este parágrafo é um dos que mais honra fazem aos ilustres Redatores do Projeto de Constituição”. Reforçaria a sua defesa argumentando que "jamais Jesus Cristo, nosso Divino Mestre, quis que se obrigasse alguém a receber violentamente a Revelação”. Assim, ninguém deveria ser perseguido ou molestado por motivo religioso, sendo uma máxima da moral universal

que não façamos aos outros o que não queremos que se nos faça. Pergunto eu: quereríamos nós sofrer perseguição e constrangimento no exercício de nossa Religião em qualquer ponto da terra, onde nos achássemos? (...) Como pois havemos nós estabelecer outra regra para aqueles que por desgraça tiverem diversa crença? Esses argumentos me parecem incontestáveis. Os que não perturbam a tranquilidade e cumprem as Leis

\footnotetext{
93 Idem.

94 Ibidem, p. 195.

95 Idem.
} 
estabelecidas têm direito a ser protegidos. Deus os vê, Deus os julgará na outra vida. ${ }^{96}$

Por fim, respondendo diretamente a Silva Lisboa, Francisco Carneiro de Campos dirá não acreditar que os brasileiros, uma vez decretada a liberdade religiosa, abandonem a "crença de nossos Pais", o catolicismo:

Os nossos Cidadãos por convicção, e por educação e por hábito, persistirão firmes na crença de nossos Pais; não haja medo que eles prefiram as práticas perniciosas a absurdas do Judaísmo ou Islamismo. Antes à vista da santidade dos nossos dogmas, da pureza da nossa moral, e da pompa de nossas solenidades e cerimônias Religiosas, muitos serão os convertidos ao grêmio da Igreja Católica, que será sempre aumentada pela mantença que se dá a seus Ministros e pela honra e consideração de que eles gozarão no Estado. ${ }^{97}$

Seu irmão José Joaquim, que havia sucedido José Bonifácio na pasta dos Negócios e Estrangeiros, manifesta-se também favoravelmente à liberdade religiosa nos termos do parágrafo. O grande estrategista e defensor do Poder Moderador tomaria, nessa matéria, uma posição mais liberal do que a de José da Silva Lisboa e de Maciel da Costa, por exemplo, expoentes do que chamamos de posição conservadora no/do campo político do liberalismo. Como jurista que era, Carneiro de Campos defende seus princípios baseandose no Direito Público, "tendo unicamente em vista garantir a cada um dos nossos Concidadãos os seus direitos, tanto quanto forem compatíveis com a segurança e felicidade geral de todos"98. A argumentação do ministro perpassa a questão da consciência e da individualidade de cada um, que é livre para adorar a Deus como bem quiser, segundo os ditames de sua própria consciência - algo muito próximo do que Antonio Carlos e Muniz Tavares haviam defendido:

Ora, a minha consciência, a minha crença e as minhas opiniões são de tal sorte minhas que a ninguém mais podem pertencer. Elas residem bem recatadas no santuário o mais impenetrável da minha alma, onde nem as Leis, nem o Governo, nem os homens podem ter ingerência alguma; só Deus ali entra, e só a ele devo dar estreitas contas dos meus pensamentos. ${ }^{99}$

\footnotetext{
96 Ibidem, p. 195-196.

${ }^{97}$ Ibidem, p. 196.

${ }^{98}$ Idem.

${ }^{99}$ Ibidem, p. 197.
} 
Logo em seguida, afirmaria que "o Estado e a Religião são coisas perfeitamente distintas e perfeitamente separadas, uma não pode ter ingerência na outra", desconsiderando e repudiando completamente o regalismo característico da administração luso-brasileira e o modus vivendi do Padroado régio. Nesse sentido, confrontava a posição e o pensamento do padre Rodrigues da Costa, defensor da união entre as duas esferas de poder. De todos os constituintes, o ministro foi o que mais se aproximou da moderna noção de Estado laico, da separação entre os poderes temporal e espiritual, defendendo a não intervenção estatal nos assuntos da Igreja. Diria ele que "o Estado não tem direito de legislar sobre a Religião que cada um abraça", devendo "conservar-se absolutamente imparcial aos dogmas dos diferentes Cultos que entre nós se estabelecem". Entretanto, tributário ainda de uma cosmovisão de Antigo Regime, Carneiro de Campos não defenderia o "princípio insustentável em Moral, como em Política" de que o Estado devesse ser indiferente à falta total de Religião. Procurando conciliar o antigo com o novo, o deputado defenderia uma posição em certo sentido ambígua, haja vista que ele propõe um Estado laico sem abrir mão da religião. Segundo o parlamentar, "tanto importa a uma boa Administração que os Sectários de todos os Cultos vivam à sombra de uma imparcial e igual vigilância, quanto é também essencial que um espírito verdadeiramente religioso anime toda a Nação". Isso porque a religião garantiria a boa moral à sociedade:

\footnotetext{
Em verdade, os meios que possui o Governo para reprimir os crimes são limitados; eles não lhe são conhecidos, senão depois de consumidos. É, portanto, indispensável que haja um meio de prevenir que eles se formem no coração, e aí só pode entrar a Religião. (...) O temor do castigo, reservado aos perturbadores da ordem pública, não pode absolutamente coibir os crimes (...) Só na Religião se encontrará o suplemento necessário às Leis civis e a uma moral sempre incompleta. ${ }^{100}$
}

Esta não será a única vez que Carneiro de Campos apresentará uma posição aparentemente paradoxal. Ocupando o cargo de ministro dos Negócios e Estrangeiros durante os primeiros dias de novembro de 1823, portanto, à época da dissolução da Constituinte, o deputado, considerado um espírito bastante conservador, sobretudo em razão de sua defesa contundente do Poder Moderador, recusar-se-á a assinar o decreto que dissolveu a Constituinte. Considerando-se que a base teórica do quarto poder, grosso

\footnotetext{
${ }^{100}$ Idem.
} 
modo, garante justamente a prerrogativa do chefe do Executivo para vetar leis provenientes das Assembleias e fechar o Parlamento, é de se questionar os motivos que levaram Carneiro de Campos a se recusar a assinar o ato de dissolução. Uma resposta possível pode ser precisamente o trânsito e a fluidez dos liberais entre posições ora mais radicais, ora mais conservadoras, havendo espaço, portanto, para soluções conciliatórias e verdadeiramente moderadas entre os dois extremos do espectro político do liberalismo.

Em seguida, em um discurso extremamente liberal e exaltado, o deputado criticaria a privação aos direitos políticos àqueles que não professarem a religião do Estado, considerando esta uma ideia "além de inútil, porque somente poderia fazer hipócritas, e não verdadeiros Católicos", uma "violência incompatível com tantos protestos de tolerância que tem proferido os ilustres Autores de semelhante proposta". Na ótica de Carneiro de Campos, apesar de os redatores do projeto falarem em tolerância e em liberdade religiosa, não eram, porém, genuinamente tolerantes, uma vez que não respeitavam "um direito inalienável de todo homem, que lhe deve ser conservado ileso tão integralmente como o possuía antes da Associação Política", qual seja, "o ser político" acima do "ser religioso":

E pensam que o respeitam, ou que são tolerantes porque não perseguem a estes desgraçados com ferro e fogo, e só querem que eles sofram a pena capital da perda do ser político, ou mesmo civil? Isto é, querem que pelo simples fato da apostasia fiquem pela Constituição privados d'aqueles direitos, que a mesma Constituição garante a seus talentos e virtudes! Querem que sejam desmembrados do Corpo Político em que estavam incorporados pelo seu nascimento, e fiquem vivendo como estrangeiros no seu País natal! Finalmente querem que o Brasileiro seja menos contemplado que o Estrangeiro que se fez Brasileiro por adoção! Como pois combinam e conciliam os ilustres Membros estas suas opiniões com a profissão de tolerância tantas vezes repetida? ${ }^{101}$

Continuaria seu discurso inflamado, clamando para que os deputados não aberrassem "das mais depuradas Luzes do século em que vivemos". "Para ser livre", prosseguiria Carneiro de Campos, "não basta que a pessoa e os bens do Cidadão estejam defendidos e seguros da opressão", sendo também "necessário que seu espírito, desembaraçado das cadeias da Tirania, possa seguir em liberdade as ideias que ele julga verdadeiras, úteis e necessárias à sua felicidade". O taquígrafo não pôde acompanhar o restante de sua fala porque "o ilustre Deputado se eletrizara de maneira, e falara com tal

${ }^{101}$ Ibidem, p. 198. 
rapidez que o não pudera seguir" ${ }^{102}$. Encerrava-se, portanto, a fala mais liberal em matéria de liberdade religiosa produzida na Assembleia Constituinte de 1823, proferida por uma grande figura do liberalismo conservador.

Carneiro de Campos será considerado pela historiografia como o principal autor da Constituição de 1824, em virtude principalmente da instituição do Poder Moderador, que havia defendido na Constituinte - "possivelmente o mais importante discurso de direito público feito na Assembleia", nas palavras de José Honório Rodrigues ${ }^{103}$. A mesma Carta Magna declararia que a religião oficial do Império continuaria sendo a católica, e que "todas as outras religiões serão permitidas com seu culto doméstico, ou particular, em casas para isso destinadas, sem forma alguma exterior de Templo"104. Comparando-se com o projeto apresentado pela Assembleia, estendia-se a liberdade religiosa a todos os cultos - ainda que com restrições à exterioridade e visibilidade dos mesmos -, e não apenas às comunhões cristãs. Porém, não obstante a contundente crítica daquele deputado, mantinha-se, no artigo 95, inciso III da Carta, a restrição dos direitos políticos daqueles que não professavam a religião do Estado ${ }^{105}$, princípio tão combatido por Carneiro de Campos na Constituinte.

Ademais, tal como definido no artigo 102 da Constituição, cabia ao Imperador nomear os bispos e prover os benefícios eclesiásticos (inciso II), bem como conceder ou negar o beneplácito aos decretos dos concílios, letras apostólicas e quaisquer constituições eclesiásticas (inciso XIV). Instituía-se, deste modo, legalmente, a continuidade da tradição regalista e de ingerência do Estado nos assuntos da Igreja, prática explicitamente criticada pelo ministro e deputado na Assembleia. Percebe-se, assim, que o principal autor da Constituição de $1824^{106}$ não conseguiria alargar o conceito de liberdade religiosa tal como seu espírito liberal ansiava e defendia, tendo êxito apenas em imprimir sua noção conservadora de soberania, representada pelo Poder Moderador, instituído pelos artigos 98, 99 e 101 da Carta $^{107}$.

\footnotetext{
102 Idem.

${ }^{103}$ RODRIGUES, José Honório. op. cit., p. 273.

104 BRASIL. Constituição (1824). Outorgada pelo Imperador d. Pedro I em 25 de março de 1824. Disponível em: http://www.planalto.gov.br/ccivil_03/Constituicao/Constituicao24.htm. Acesso: 14/03/2016.

105 “Art. 95. Todos os que podem ser Eleitores, hábeis para serem nomeados Deputados. Excetuam-se: (...) III. Os que não professarem a religião do Estado".

${ }^{106}$ RODRIGUES, José Honório. op. cit., p. 274.

107 “Art. 98. O Poder Moderador é a chave de toda a organização Política, e é delegado privativamente ao Imperador, como Chefe Supremo da Nação, e seu Primeiro Representante, para que incessantemente vele sobre manutenção da Independência, equilíbrio e harmonia dos mais Poderes Políticos".

“Art. 99. A Pessoa do Imperador é inviolável e Sagrada: Ele não está sujeito a responsabilidade alguma”.
} 
O único representante da Paraíba a tomar parte na discussão, Joaquim Carneiro da Cunha, tomaria a palavra para defender o parágrafo. O ex-revolucionárioa de 1817 , que em 1824 iria assinar o manifesto contra a dissolução da Constituinte, responsável por deflagrar a Confederação do Equador, afirmaria que a moral do catolicismo foi sempre a mesma: "Não faças a outrem aquilo que não quiseres para ti" ${ }^{108}$. Conciliando o antigo e o novo, recorre à pureza original da comunhão cristã, entendida como eixo estruturante da sociedade, argumento que a união entre Estado e Igreja havia sido manchada porque os "Ministros de Jesus Cristo abusaram da Religião", como era o caso do já citado cisma ocorrido entre a Inglaterra e a Igreja.

A recorrente menção à Inglaterra é significativa da influência que esta exercia na política imperial brasileira, tema bastante estudado pela historiografia ${ }^{109}$. Mais uma vez, um constituinte apoiava a atitude inglesa ante os "abusos" de Roma, um forte indício de que a Igreja no Brasil não possuía fortes e consolidados vínculos com a Cúria Romana. Corroboram para tal afirmativa o fato de a Constituição de 1824, ou seja, um poder laico, ter transferido as prerrogativas do padroado régio para a figura de d. Pedro I antes mesmo do reconhecimento da Independência do Brasil pela Santa Sé ${ }^{110}$. Tal autonomia expressarse-ia na futura atuação de parcela do clero nacional, a qual, liderada pelo futuro regente e padre, Diogo Antônio Feijó, vislumbraria a "possibilidade de constituir-se uma Igreja nacional, cujo centro de unidade seria um Concílio Nacional" ${ }^{111}$, onde, entre outras mudanças, extinguir-se-ia a obrigatoriedade do celibato.

\footnotetext{
“Art. 101. O Imperador exerce o Poder Moderador:

I. Nomeando os Senadores, na forma do Art. 43.

II. Convocando a Assembleia Geral extraordinariamente nos intervalos das Sessões, quando assim o pede o bem do Império.

III. Sancionando os Decretos, e Resoluções da Assembleia Geral, para que tenham força de Lei.

IV. Aprovando e suspendendo interinamente as Resoluções dos Conselhos Provinciais.

V. Prorrogando, ou adiando a Assembleia Geral e dissolvendo a Câmara dos Deputados, nos casos que exigir a salvação do Estado, convocando imediatamente outra, que a substitua.

VI. Nomeando e demitindo livremente Ministros de Estado.

VII. Suspendendo os Magistrados nos casos do Art. 154.

VIII. Perdoando e moderando as penas impostas e os Réus condenados por Sentença.

IX. Concedendo Anistia em caso urgente, e que assim aconselhem a humanidade e bem do Estado".

${ }^{108}$ Diário da Assembleia Geral, Legislativa e Constituinte..., op. cit., t. III, p. 198.

${ }^{109}$ Sobre o assunto, cf. BETHEL, Leslie. “O Brasil no século XIX: parte do “império informal britânico'?”.

In: CARVALHO, José Murilo de; CAMPOS, Adriana Pereira (orgs.). Perspectivas de cidadania no Brasil Império. Rio de Janeiro: Civilização Brasileira, 2011, p. 15-35.

${ }^{110}$ Sobre o assunto, cf. CORDEIRO, Cecília Siqueira. A liberdade religiosa na Assembleia Constituinte de 1823. Monografia de final de curso. Universidade de Brasília, Brasília, 2013, capítulo 2. O reconhecimento só veio após a assinatura do Tratado de Paz, Amizade e Aliança (15 de novembro de 1826), no qual Portugal consentia com a Independência do Brasil. O espírito que animava a diplomacia brasileira com relação à Santa Sé pode ser apreendido nas instruções ao enviado do Brasil a Roma, as quais equivaliam a ameaça de um cisma.

${ }^{111}$ HAUCK, João Fagundes. “Quarto período: a Igreja na emancipação...”. op. cit., p. 14.
} 
Nicolau Vergueiro, magistrado e representante de São Paulo, futuro diretor do curso jurídico desta cidade, faria coro aos demais deputados favoráveis ao referido parágrafo que tratava sobre a liberdade religiosa. $\mathrm{O}$ deputado defenderia que a fonte da intolerância não provinha da religião, mas sim “da mistura, que se tem feito, dos poderes do Chefe da Igreja com os do Trono":

Logo que se uniram estes poderes, e se lançaram no mesmo livro de Registro as Leis Eclesiásticas e as Civis, confundiam-se por esta mistura os limites dos dois poderes; e nós, que conhecemos os limites dos nossos, não passemos além deles. $\mathrm{O}$ que nos pertence é a Glória Nacional, e o bem geral da sociedade, e ao Corpo Religioso o conduzir o homem para a felicidade espiritual. Não devemos ir contra a marcha dos Ministros da Religião, nem eles opor-se à nossa, devemos caminhar em harmonia, além do que o metermo-nos nos sentimentos do homem é seguramente a maior das tiranias (Apoiado). ${ }^{112}$

Vergueiro utilizar-se-ia de argumentação semelhante a Carneiro de Campos, advogando em favor da separação dos assuntos da Igreja e do Estado. Em seu discurso defenderia, tal como já fora feito por outros deputados, que a garantia da liberdade religiosa não autorizava "o que é Católico Romano a fazer-se Herege ou Maometano", apenas mostrava ao "Cidadão que ele tem a livre escolha do exercício da Religião"113. Finalizada a sua manifestação, o presidente Martim Francisco deu por adiada a discussão por ter chegado a hora dos pareceres, e a sessão levantou-se, como de costume, por volta das duas horas da tarde.

Aos 9 de outubro, retomou-se pela terceira sessão seguida o debate acerca do parágrafo $3^{\circ}$ do artigo $7^{\circ}$ do projeto de Constituição. Manoel de Souza França seria o primeiro orador do dia, relembrando que havia sugerido à Assembleia que se suprimisse todo o artigo $7^{\circ}$, a fim justamente de "poupar à mesma Assembleia esta divergência de opiniões, em que vejo agora flutuar" ${ }^{\prime 14}$. Declararia que o referido direito assim enunciado permitiu que se fizesse dele "uma tese tão absoluta que ofende aos pios ouvidos dos timoratos em matérias de Religião", acrescentando achar "na verdade bem estranho (...) ser de uma Constituição o tratar-se nela de coisas de outro Mundo" ${ }^{115}$. Para o magistrado e representante do Rio de Janeiro, "se aqui se tem tido (...) lugar questões de semelhante natureza, é só pelo lado de obstar a que o Despotismo torne outra vez a levar o seu império

\footnotetext{
${ }^{112}$ Diário da Assembleia Geral, Legislativa e Constituinte..., op. cit., t. III, p. 199.

${ }^{113}$ Ibidem, p. 200.

${ }^{114}$ Ibidem, p. 205.

${ }^{115}$ Ibidem, p. 205-206.
} 
até o Santuário do coração humano, erigindo em Direito o abuso de dominar as consciências" $" 116$.

Por fim, criticaria veementemente os abusos e tirania da Igreja, nomeadamente a ação do Tribunal do Santo Ofício, esse "gênio do mal que açoitado das luzes da razão desapareceu já dentre as Nações que aviltava”:

Entendamo-nos, Srs., estas questões de Religião nunca teriam lugar, nem cabimento em Assembleias Políticas, como é a nossa, se a mesma Religião se não tivera convertido pelo gênio do mal em modo e maneira honesta de se perseguir a inocência da virtude natural, chegando o abuso da tirania até ao excesso de levantar Juízos privativos com a alcunha de Tribunais de Ofício Santo, ou Santo Ofício, segundo lhe chamam, para perseguir o Cidadão virtuoso, e condená-lo indefeso à morte, como por Mandato de Deus, alucinando os Povos com prestígios de que a Divindade aprova a barbaridade dos assassínios cometidos em seu nome. ${ }^{117}$

Nicolau Vergueiro e Silva Lisboa voltariam a se pronunciar, defendendo novamente os mesmos argumentos das sessões anteriores, embora em campos opostos. $\mathrm{O}$ veterano Silva Lisboa tornaria a advogar que a liberdade religiosa "não tem sido demandada pela Nação, e nem ainda inculcada nos escritos públicos" ${ }^{118}$. Além do mais, respondendo aos deputados que defendiam o parágrafo como uma necessidade das "Luzes do Século", Silva Lisboa buscará inspiração no grego Sólon, para os qual não se deve

fazer ao povo bens à força, e por isso quando este sábio formou a Legislação para a República de Atenas, deu a satisfação de que não tinha feito as melhores Leis, mas só aquelas que o Povo podia suportar. ${ }^{119}$

Nesse sentido, considerava que a nação brasileira não estava pronta, ainda, para uma legislação tão liberal no quesito religioso, tendo em vista a pouca instrução de grande parcela da sociedade, que, devido a seu espírito fraco e dado à libertinagem, abandonaria a religião católica, tão importante para inculcar a "boa moral" nesta mesma sociedade. Na visão conservadora de Lisboa, até mesmo nações civilizadas, como a França, haviam pecado no excesso de liberdade, levando à ruína deste reino outrora "Cristianíssimo":

\footnotetext{
${ }^{116}$ Ibidem, p. 206.

${ }^{117}$ Idem.

${ }^{118}$ Ibidem, p. 207.

${ }^{119}$ Idem.
} 
Foi a imprudência e insolência dos que pregaram a Tolerância absoluta, ridicularizaram as Religiões positivas, e até entronizaram a Deusa da Liberdade, profanando os Templos com hórrida Idolatria, até que o Ateísmo triunfante os destruiu. ${ }^{120}$

Dentre os raros campeões da religião romana descritos por Roque Barros, talvez o grande defensor dessa corrente, anterior à reação ultramontana ${ }^{121}$, tenha sido o futuro visconde de Cairu, José da Silva Lisboa. Mesmo quando alguns membros da Assembleia criticaram os "abusos" da Igreja e defenderam a liberdade religiosa em conformidade com as "Luzes do século", o baiano, nesse assunto, advogaria pelas prerrogativas espirituais e defenderia a religião católica, responsável por civilizar várias partes do mundo ocidental:

Todos de timorata consciência, fiéis a seu juramento, e convencidos de ser a Religião Católica a Religião por excelência, vendo que ela pôs o pé firme na América desde o México até o Cabo de Horne, e que sob o seu abrigo cresceram tantos Estados, não acharão razoável que, com a relaxação proposta, e não pedida, se ponha em risco de se perder a Igreja do Ocidente, como já quase se extinguiu no Oriente. ${ }^{122}$

Quanto à denúncias de abusos e erros da Igreja católica, Lisboa os creditaria à "ferrugem dos Séculos" e não propriamente à ação de seus integrantes, preferindo-os às heresias:

Ainda onde a Religião dominante se acha envolvida em erros causados pela ferrugem dos Séculos, todavia é isso menos mal, para que não venha coisa pior com a faculdade de se poderem seguir as abominações das Heresias. ${ }^{123}$

O padre Henriques de Resende voltaria a se pronunciar, repetindo os argumentos de que o catolicismo já havia sido muito amparado pela Constituição: "este Projeto tanto protege o Catolicismo, que até passa a ser injusto com as outras Seitas"124. Seu discurso

\footnotetext{
120 Idem.

${ }^{121}$ A "vaga ultramontana" teve início com os pontificados de Gregório XVI (1831-1846) e de seu sucessor Pio IX (1846-1878), adversários intransigentes das "liberdades modernas". Os dois defenderiam um catolicismo conservador e imutável, princípios expressos principalmente nas encíclicas Quanta Cura e Syllabus. As ideias ultramontanas encontrariam eco no Brasil a partir da década de 1860, servindo de escopo teórico para a Questão Religiosa (1872-1875). Sobre o assunto, cf. BARROS, Roque Spencer M. de. "Vida religiosa" e "A Questão Religiosa". In: HOLANDA, Sérgio Buarque de; CAMPOS, Pedro Moacyr (dirs.). op. cit., p. 318-365.

${ }^{122}$ Ibidem, p. 207-208.

${ }^{123}$ Ibidem, p. 209.

${ }^{124}$ Idem.
} 
mencionava, ao contrário do que postulara Maciel da Costa e outros, que existiam outras religiões além do catolicismo dentro dos limites do Império do Brasil:

O Estado é o agregado de todos os súditos do Império, todos estes contribuem para o Estado, e o Estado só sustenta o Catolicismo e seus Ministros (...) donde se segue que os indivíduos de todas as Seitas, como Membros do Estado, pagam para sustentação do Culto Católico, e o seu é pago por eles em particular. Ainda faz mais esse projeto: deixou aos Bispos Católicos o direito da censura sobre os Escritos Religiosos dos Católicos, e aos outros não deixou essa garantia. Tudo isso é uma grande favor e proteção particular prestada ao Catolicismo. ${ }^{125}$

Contudo, o padre não achava prudente admitir a liberdade religiosa a toda e qualquer religião, mas apenas a "todas as Religiões positivas" ${ }^{126}$, compatíveis com a realidade brasileira. Para ele,

se admitíssemos as Religião Maometana, que adota a poligamia, aí teríamos a poligamia no Brasil, o que é contra os nossos costumes; se admitíssemos Religiões Idólatras, aí teríamos no Brasil Idolatria, teríamos costumes opostos. O Povo seria desunido, e consequentemente fraco. ${ }^{127}$

Para tanto, defenderia a sua emenda proposta na sessão anterior de uma razoável liberdade religiosa, porque não julgava sensato estabelecer-se tal liberdade “indistintamente, admitindo entre nós Religiões com costumes e moral inteiramente opostos aos nossos, o que de certo viria introduzir a divisão, e, portanto, separação entre indivíduos da mesma Nação"128.

Maciel da Costa discursaria novamente para criticar a disposição do artigo, o conteúdo do $\S 3^{\circ}$ e o redator do projeto, Antonio Carlos. Quanto ao conteúdo, defenderia que o povo brasileiro

não é um agregado de selvagens que se ajuntam para se constituírem pela primeira vez, e para formarem um Estado, onde tudo é preciso criar. O Povo Brasileiro é um Povo feito a muitos respeitos, e a respeito de Religião, perfeito e consumado. Tem um passado, sumamente glorioso, tem um presente, e quer um futuro que deseja preparar. Tem instituições, tem costumes, hábitos e opiniões, que lhe são mui caras, e que procura manter, garantir e segurar em o (sic) novo Pacto Social que contrai. E uma das coisas, que deseja com muita especialidade conservar

\footnotetext{
${ }^{125}$ Idem, grifo nosso.

${ }^{126}$ Idem.

${ }^{127}$ Ibidem, p. 209-210.

${ }^{128}$ Ibidem, p. 210.
} 
ilesas, é a Religião de seus Pais, com a qual está de todo identificado, e por isso o pôs como condição sine qua non na fachada do edifício que levanta. ${ }^{129}$

O fato de o projeto conservar o catolicismo como culto oficial do Império e mantêlo com rendas públicas nada mais era do que uma "estéril declaração", tendo em vista que, ainda segundo deputado, existiria uma "fácil tendência de homens sem instrução, e perdidos por paixões desenfreadas, para o esquecimento e o desprezo de toda a Religião, e para a indiferença, que é o cancro roedor de toda moral". Como se vê, sua posição era a mesma de Silva Lisboa, pois ambos entendiam que aprovar o parágrafo tal qual se encontrava iria ocasionar um “mal horrível” à nação. Maciel da Costa argumentaria que

constituições políticas as mais liberais e mais perfeitas idealmente não servem para nada, se os povos a quem se destinam não estão ainda nos termos de as receberem, e não havendo a instrução pública e boas instituições universalizando ainda o espírito público, e dado bases filosóficas à moral dos Povos, correm os Estados grande risco em se (...) sancionarem certos princípios gerais, que podem cortar os vínculos Religiosos que os prendem e contém, do que temos bem doloroso exemplo na história das revoluções de nossos dias. ${ }^{130}$

Francisco Gê de Acayaba Montesuma, representante da Bahia, que não contava 30 anos completos durante a Constituinte, também discursaria a favor do polêmico parágrafo. Para o deputado,

os ilustres Redatores do Projeto quiseram só declarar que a Constituição na parte Religiosa não seria menos liberal que nas outras. Isto é, que a Constituição Brasileira, reconhecendo os direitos inalienáveis e imprescritíveis do Cidadão, também reconhecia o que o homem tem de prestar a Deus o Culto que lhe ditar seu coração (...) Porque assim como nós queremos que o Cidadão seja livre enquanto Cidadão, também o devemos declarar livre como homem Religioso. ${ }^{131}$

A seguir, o Bispo-Capelão Mor, d. José da Silva Caetano Coutinho, fará um longo discurso, do qual o taquígrafo só pôde resumir que desaprovava "toda a espécie de perseguições, fanatismos ou barbaridades parecidas com os procedimentos do extinto Tribunal intitulado Santo Ofício", que fora tantas vezes mencionado pelos deputados, mas que "igualmente não podia admitir a tolerância legal de todas as Religiões sem

\footnotetext{
${ }^{129}$ Ibidem, p. 210-211.

${ }^{130}$ Ibidem, p. 211, grifo nosso.

${ }^{131}$ Ibidem, p. 212.
} 
necessidade legítima"132. Ou seja, a maior autoridade eclesiástica da Constituinte posicionou-se contra a liberdade de culto, e ao que tudo indica defendeu a religião católica, corroborando com a posição de outro membro do clero, Rodrigues da Costa.

Seguiram-se novo discurso de Antonio Carlos - que praticamente sintetizara todos os argumentos defendidos até então pelos apoiadores do parágrafo, recebendo uma série de apoiados ao longo de sua fala -, de João Faria Lobato e de José Custódio Dias. Faria Lobato apresentaria uma emenda ao artigo, sugerindo que ao invés de se falar em liberdade religiosa, se "dissesse que esse direito individual consistia em ninguém ser inquietado em suas opiniões sobre Religião" 133 , pois assim se evitariam "interpretações sinistras" ao texto do parágrafo, o que acabou sendo rejeitado pela Assembleia. Custódio Dias, por sua vez, posicionar-se-ia ao lado de Montesuma, Muniz Tavares, Antonio Carlos e tantos outros que defenderam a doutrina do parágrafo, encerrando o debate acerca do assunto.

Julgou-se finalmente a matéria discutida e, interrogada a Constituinte, venceu-se que o $\S 3^{\circ}$ do artigo $7^{\circ}$ passava sem modificações. Saíam derrotados Maciel da Costa, Silva Lisboa, Bispo Capelão-Mor e o padre Rodrigues da Costa, que tentaram, ao longo de três sessões, defender o status quo, ou seja, manter as prerrogativas da Igreja e da religião católica. Para tanto investiram no argumento do caráter oficial de seu culto e da noção de que o catolicismo era o fundamento moral da sociedade, servindo-lhe como freio e suplemento às leis civis. Mas o debate acerca da liberdade religiosa iria ressurgir quando da discussão e votação dos artigos 14, 15 e 16 do projeto constitucional, os quais forneciam as "explicações e modificações" - leia-se "limitações" - necessárias ao direito individual elencado no artigo $7^{\circ}, \S 3^{\circ}$.

Aos 29 de outubro, quando o artigo 14 entrou na ordem do dia, o magistrado e representante paulista Francisco de Paula e Mello sugeriu que se discutissem conjuntamente os artigos 14, 15 e 16 "pela conexão que tem entre si" ${ }^{134}$, o que foi acatado pela Assembleia. Entravam em discussão, portanto, os três artigos, nestes termos concebidos:

Art. 14. A liberdade Religiosa no Brasil só se estende às comunhões Cristãs: todos os que as professarem podem gozar dos Direitos Políticos do Império.

\footnotetext{
${ }^{132}$ Idem.

${ }^{133}$ Ibidem, p, 213.

${ }^{134}$ Ibidem, p, 330.
} 
Art. 15. As outras Religiões, além da Cristã, são apenas toleradas, e a sua profissão inibe o exercício dos Direitos Políticos.

Art. 16. A Religião Católica Apostólica Romana é a Religião do Estado por excelência, e única mantida por ele. ${ }^{135}$

A proposta dos autores do Projeto de Constituição, portanto, define uma hierarquização entre as religiões. Em primeiro lugar encontrava-se a religião católica, religião do Estado por excelência e única mantida por ele. Ou seja, era o governo imperial quem distribuía as côngruas ao clero, recolhia o dízimo dos fiéis e nomeava bispos e prelados. Em segundo lugar vinham as "comunhões cristãs", precisamente as religiões protestantes como o luteranismo, calvinismo e anglicanismo. A esses cultos estendiamse a liberdade religiosa e os direitos políticos porque possuíam, apesar das divergências, uma matriz cristã comum: baseavam-se na Bíblia e nos ensinamentos de Jesus Cristo. Entende-se esse artigo à luz das circunstâncias históricas do Brasil à época: desde 1810, devido às fortes relações comerciais e econômicas com a Inglaterra, permitia-se o culto em casas para isso destinadas - sem forma exterior de templos - aos protestantes ingleses que aqui viessem a residir. Os redatores do projeto, portanto, resguardaram os protestantes "úteis" ao país, como era o caso do escocês Lord Cochrane, admitindo-se que gozassem dos direitos políticos, ou seja, que pudessem ser "membros das diversas autoridades nacionais e das autoridades locais, tanto municipais como administrativas", concorrendo "para a eleição dessas atividades"136. Quanto às demais religiões, como, por exemplo, o judaísmo, o islamismo e as religiões de matriz africana - às quais os deputados geralmente referiam-se como "seitas" - declarava-se que seriam apenas toleradas, sendo vedados os direitos políticos a seus praticantes. Nesse sentido, garantia-se que não haveria perseguições aos fiéis, mas que estes, porém, deveriam restringir o seu culto ao ambiente doméstico e particular.

O deputado por São Paulo Manoel Joaquim de Ornelas, afirmando ser a matéria destes artigos “de maior importância, porque a Religião não só é o mais poderoso socorro do coração do homem (...), mas também por ser o mais seguro meio de o manter em sociedade", criticaria o artigo 15. Para o paulista, todas as religiões diversas da católica seriam "falsas e monstruosas", haja vista que "todos conhecem as doutrinas de Lutero, Calvino e outros Heresiarcas, e todos sabem o que eles pensavam dos principais

\footnotetext{
${ }^{135}$ Ibidem, p. 329-330.

${ }^{136}$ Art. 29 do Projeto de Constituição apud MELLO, F. I. Marcondes Homem de. op. cit., p. 42.
} 
fundamentos da nossa Fé"137. Sob tal ponto de vista, oferecia à Mesa uma emenda alterando a redação do artigo 14, acrescentando que o "culto público só é permitido no Brasil aos da Comunhão Católica Apostólica Romana"138. O Diário restringe-se a afirmar que sua proposta foi "apoiada" pela Assembleia. Antonio Carlos também sugeriria uma emenda neste sentido, deixando em evidência que apenas à religião católica "compete o culto externo fora das Igrejas" ${ }^{139}$, embora defendesse, diferentemente de Ornelas, que se deviam estender os direitos políticos a todos os professantes de comunhões cristãs, e não só aos católicos.

O padre mineiro Antonio da Rocha Franco daria a sua primeira contribuição ao assunto, mostrando-se favorável à liberdade religiosa contida no projeto: "Não sei que se possa dar Religião sem liberdade, como seja o seu primeiro Santuário o coração humano, onde não chega a força, nem a violência". Porém, propunha um aditamento aos artigos em questão, a fimm de "fazer extensiva essa liberdade ao Judaísmo, ou Religião Judaica, assim pela muita afinidade que tem com a nossa", seja por sua antiguidade e origens, seja pela "Santidade de suas figuras" $"$. Afinal,

todos sabemos que Maria Santíssima foi Judia, foi Judeu o grande Batista, que não teve maior entre os nascidos (...) foram Judeus os Apóstolos, Jesus Cristo mesmo, o fundador da nossa Igreja, foi Judeu. ${ }^{141}$

Em sessão anterior, Francisco Carneiro de Campos, ao contrário de Rocha Franco, já havia caracterizado as práticas judaicas como "perniciosas e absurdas", equiparandoas ao islamismo.

O padre Henriques de Resende também sugeriria uma emenda, desta vez ao artigo 16. Preocupado com os "fanáticos, os inimigos da Constituição" capazes de se utilizar da liberdade religiosa para "suscitarem os povos", uma vez que "já por aqui [na Assembleia] se diz que se quer destruir a Religião [e] já aparecem pasquins e sonetos dizendo que se quer plantar o Ateísmo", propunha que ao artigo 16 se acrescentasse: "e o Católico que apostatar abraçando outra seita ficará privado do exercício dos direitos políticos" ${ }^{142}$. Desta forma, a Assembleia esclareceria a seus inimigos que não pretendia nem destruir a

\footnotetext{
${ }^{137}$ Diário da Assembleia Geral, Legislativa e Constituinte..., op. cit., t. III, p. 329.

${ }^{138}$ Ibidem, p. 330.

${ }^{139}$ Idem.

${ }^{140}$ Idem.

${ }^{141}$ Ibidem, p. 331.

${ }^{142}$ Idem.
} 
religião, nem promover o ateísmo. Seu aditamento foi também apoiado pelo plenário, revelando esse viés preponderante da Assembleia.

Luís José Carvalho e Mello, que assumiria a pasta de Estrangeiros em 10 de novembro de 1823, substituindo José Joaquim Carneiro de Campos, levantar-se-ia para discursar pela primeira vez sobre a matéria. Posicionou-se como contrário tanto ao método enunciativo do artigo $7^{\circ}$, quanto à liberdade religiosa, que acreditava

encher de pavor e susto as consciências tímidas que se persuadirão de que fica sendo livre a qualquer dos nossos cidadãos, que professam desde o berço a Religião Católica Romana, o abraçar qualquer outra Religião. ${ }^{143}$

Louvava os artigos 14, 15 e 16 por estabelecerem limites à liberdade de culto, pois assim “não ficava tão assustadora a ideia de Liberdade Religiosa, não dando lugar aos timoratos a que pensem que assim se estabelece a ampla e larga liberdade de consciência" ${ }^{\prime 144}$. Para o deputado baiano, cabia ao legislador combinar esta liberdade com a "segurança do culto dominante, (...) evitando os perigos das controvérsias, do proselitismo e querelas de Religião" ${ }^{145}$. Luís José de Carvalho e Melo, futuro redator da Constituição de 1824, defendia, assim, uma razoável e limitada liberdade de culto, mostrando-se contrário a qualquer tipo de perseguição, desde que respeitada a religião do Estado:

\footnotetext{
O ponto está em que o Estado combine por tal modo o uso e prática das diversas Religiões que se conserve a paz. Que a Religião principal do Estado não perca seu lustro e esplendor, e não se sigam perseguições. Por certo não as haverão, guardandose a regra de que seja o culto das [religiões] toleradas particular, e se evitem ofensas de interesses nessa matéria. ${ }^{146}$
}

Essa visão hierarquizante da prática religiosa prevalecerá na Carta Magna de 1824, segundo a qual a religião oficial continuaria a ser a católica, tolerando-se as demais religiões, que só poderiam contar com cultos particulares em casas para isso destinadas, sem forma exterior de templo. Na prática, mantinha-se o que já acontecia com a Igreja Anglicana no Brasil, que era tolerada, como bem relembrou o deputado Carvalho e Mello, desde o "Tratado de 19 de Fevereiro de 1810, e dele não se seguiu ainda o mais leve

\footnotetext{
${ }^{143}$ Ibidem, p. 332

${ }^{144}$ Idem.

145 Ibidem, p. 333.

146 Idem.
} 
perigo, nem receio de desassossego", apesar de que, "deslizando-se os Ingleses algum tanto do que lhes fora permitido, construíram Igrejas com exterior próprio delas o que lhes fora expressamente denegado" ${ }^{147}$. Por fim, Carvalho e Mello concordava, diante dos casos concretos da existência de protestantes no país, em estender os direitos políticos apenas às comunhões cristãs, ou seja, àquelas que professavam a "suavíssima, pura e divina moral", ao passo que as religiões acatólicas possuíam cultos extravagantes "de que se não podem esperar virtudes morais e políticas" ${ }^{\text {"148 }}$. Na Constituição de 1824, porém, os direitos políticos restringiram-se àqueles que professavam a religião de Estado, conforme disposto no artigo 95, inciso III.

Silva Lisboa, o deputado com mais intervenções sobre a matéria, torna a falar e se posicionar contra os artigos 14 e 15 e também contra o constituinte Antonio Carlos, a quem chama "Apologista do Projeto"149. Critica novamente a liberdade religiosa, ainda que só dentro do grêmio das comunhões cristãs (art. 14), porque equivale à "permissão indefinida de serem os Nacionais perjuros, apostatas, infiéis, ímpios" $" 150$. Justificava-se afirmando que "quase todos os Sectários das Comunhões Cristãs, dissidentes da Religião Católica, dizem que só eles estão no verdadeiro Cristianismo da Igreja Reformada, e que os Sectários do Catolicismo estão na Cristandade corrupta"151. Tal situação jamais poderia ser útil a um Império que jurou defender as prerrogativas da religião católica e que era formado por um "povo de Irmãos, desde o Rio Negro até o Uruguai”, que professava e prezava uma única religião desde seu descobrimento:

Congratulamo-nos de pertencer à Terra de Santa Cruz, onde primeiro se arvorou este Símbolo da nossa Redenção, levantando-se o Altar em Porto Seguro pelo Descobridor Cabral na Páscoa de Ressurreição de 1500, assistindo à Missa sobre os montes vizinhos os Indígenas do País, imitando os mesmos Atos de adoração que viam fazer os Descobridores (...) Dando depois em Regimento aos Governadores os Monarcas de Portugal, que, sobretudo, cuidassem da propagação da Fé Católica, declarando prezá-la mais que a riqueza do país. Graças aos Céus! ${ }^{152}$

Silva Lisboa, experiente e fiel católico, criticava a "devassidão da mocidade", que em grande parte se encontrava "corrompida pela superficial leitura de livros ímpios e

\footnotetext{
${ }^{147}$ Ibidem, p. 334.

148 Idem.

${ }^{149}$ Ibidem, p. 335.

${ }^{150}$ Idem.

${ }^{151}$ Ibidem, p. 336.

152 Idem.
} 
obscenos da França degenerada". O combativo deputado argumentava que até mesmo o "Paradoxista Rousseau, entre as suas extravagâncias, reconheceu a necessidade de terem os homens caráter decidido em sua Profissão Religiosa" - o pensador francês franqueara a liberdade na escolha de culto, mas abominava a "inconstância e versatilidade" dos apóstatas. $\mathrm{O}$ ex-censor régio e defensor da Igreja católica não compreendia "donde vem tantas dúvidas contra a Religião Católica" ${ }^{\text {153 }}$, se não porque ela

não dá quartel à apetite animal, e vício algum, e requer até a pureza dos pensamentos, porque destes emanam as ações boas ou más (...) Esta Religião é a que deu proteção contra a inconstância e lascívia do homem ao sexo feminino, declarando-o inviolável, e de toda a vida, o grande Sacramento do casamento, assegurando também a honra e paz das famílias e o estado legítimo dos filhos. Ela também declarou a Castidade como Angélica virtude, no que só discordam os hereges e libertinos, e os revolucionários Legisladores da França ${ }^{154}$

Tais revolucionários postularam que a "Nação não reconhecia votos contra a Natureza", estando, porém, "hoje demonstrada em Inglaterra pelo grande Economista Malthus que a continência pública é o que salva as Nações do excesso da população abusiva e proletária, que ocasiona as Revoluções, pestes e guerras"155. Resumidamente, infere-se do discurso de Silva Lisboa que a Igreja Católica funcionava com um verdadeiro freio político, moral e social, condenando e controlando os excessos da carne, a libertinagem e os instintos animais dos homens, e também o ímpeto revolucionário que tanto mal causara à França, levado a cabo por figuras como Voltaire, "o corifeu dos infiéis do Século passado". Finalizava seu discurso de católico moralista e de súdito fiel afirmando que a liberdade religiosa se destinava "somente para os libertinos, estudantes dos livros ímpios da França" ${ }^{156}$, causadores de desordens.

Na sessão do dia 30 de outubro, Antonio Carlos Andrada Machado, ofereceria uma nova emenda ao artigo 14, concebida em tais termos:

Art. 14. Cada Membro das Comunhões Cristãs pode professar a sua Religião, mas o culto público só lhe pertencerá uma vez que a legislatura lh'o conceda, atentas as circunstâncias do tempo, lugar, e estado de luzes da Nação. Todos, porém, que seguirem estas comunhões podem gozar dos direitos políticos. ${ }^{157}$

\footnotetext{
153 Ibidem, p. 337.

${ }^{154}$ Idem.

${ }^{155}$ Idem.

${ }^{156}$ Ibidem, p. 338.

${ }^{157}$ Ibidem, p. 342.
} 
Percebe-se que o deputado, que desde o princípio defendia ser a consciência individual um santuário, sendo livre ao indivíduo adorar a Deus como melhor lhe convier, redireciona seu discurso ao buscar restringir seu conceito de liberdade religiosa. Não havia, no Projeto de Constituição por ele redigido e apresentado à Assembleia, indícios de que se privaria o culto público das comunhões cristãs, uma vez que o art. 14 originalmente estendia a liberdade religiosa a estas comunhões, sendo apenas toleradas as demais seitas. Agora, porém, acompanhando o movimento majoritário dos debates, apoiava que se proibisse a exterioridade de culto às demais religiões diversas da católica, muito provavelmente convencido de que predominava o princípio de defesa da Igreja católica em detrimentos das demais religiões. Proibição, vale ressaltar, que duraria até que as "circunstâncias do tempo, lugar e estado de luzes da Nação" pedissem o contrário.

Os dias seguintes são muito agitados na Assembleia. Aos 4 de novembro, Francisco Muniz Tavares apresenta à Mesa a sua demissão ao cargo de deputado após artigo publicado no jornal Sentinela da Liberdade na Guarita de Pernambuco, editado por Cipriano Barata. Segundo Muniz Tavares, o "miserável autor" do periódico "só tem por fim plantar a anarquia em minha muito amada Província, sublevar os seus habitantes e fazê-los separar da União Brasílica"158. Acrescentava que o artigo incitava os eleitores da Bahia a cassarem o seu mandato de deputado, fato que considerava uma afronta a sua honra. Além desse episódio, aos 6 de novembro, o secretário Miguel Calmon leria o requerimento do cidadão David Pamplona Corte Real acerca da agressão que sofrera por dois oficiais portugueses da Artilharia Montada que acreditavam ser ele o "Brasileiro Resoluto", autor de carta que criticava a incorporação de militares lusos às fileiras brasileiras. David Pamplona suplicava "mui respeitosamente" à Assembleia que tomasse providências quanto à "segurança pública e individual dos Cidadãos Brasileiros, atacada só porque são reconhecidos por Brasileiros" ${ }^{\text {159 }}$. Tal requerimento inflamaria os deputados, agravando a crise da dissolução, que teria seu fim trágico apenas seis dias depois. Antonio Carlos, por exemplo, afirmaria que

esta matéria deve ser decidida com urgência. É na verdade original que o ser Brasileiro, e ter sentimentos Brasileiros, sirvam de motivo para ser este homem atacado por aqueles que estão ao

${ }^{158}$ Ibidem, p. 350.
${ }^{159}$ Ibidem, p. 369. 
serviço do Brasil. Eis-aqui uma prova de que a Nação está dividida em dois partidos. Cumpre que estejamos alerta. ${ }^{160}$

Montesuma, por sua vez, também requereria a urgência no assunto, por não ser "um caso ordinário" e ser um "negócio de tristes consequências". Para o deputado, o episódio era bastante simbólico:

\begin{abstract}
Não é somente o ato de dar umas pancadas, há muitas circunstâncias que o agravam. Nós não devemos olhar com desprezo para esse cidadão queixoso, que vem procurar asilo neste sagrado recinto, na Representação Nacional (...) Eu vejo que dois Oficiais Portugueses foram atacar a casa de um Cidadão Brasileiro, e como eu tenho aqui falado a favor da minha pátria, e contra tudo o que é Lusitano, receio que a qualquer dia me façam o mesmo. ${ }^{161}$
\end{abstract}

Foi nesse clima conturbado que foram finalizados os debates acerca dos artigos 14, 15 e 16 do projeto de Constituição. O acirramento das animosidades entre os deputados refletir-se-ia em seus discursos. Rodrigues da Costa, ao tratar dos referidos artigos, afirmaria se posicionar antes como político do que como católico e sacerdote, repetindo seus argumentos de que a extensa liberdade religiosa escandalizaria um povo inteiramente católico e afirmando ter recebido cartas de sua província

que relatam quanto susto e sobressalto tem causada nela somente a leitura deste Artigo que aparece no Projeto de Constituição. Artigo que parece querer destruir pela raiz os Santos Mistérios da nossa Fé. ${ }^{162}$

Responderia aos deputados que haviam defendido que "entre os Protestantes se achavam homens mais bem morigerados do que entre os Católicos Romanos" e que, para tanto, valeram-se da "moral da Inglaterra e outros Países", censurando "a imoralidade Portuguesa, asseverando que era maior a corrupção dos costumes entre eles do que entre aqueles". Admitindo que esse pode ser o caso dos portugueses "do Século presente", uma vez que adotam "cegamente os costumes Estrangeiros" ${ }^{163}$, exaltaria, porém, a história desse povo, formado por heróis e pessoas virtuosas os quais admirava:

Mas se consultarmos a História antiga dos nossos maiores, pasmaremos de admiração. Eu vejo um povo todo de Heróis, um povo inteiro praticando pela virtude, e pela Religião ações dos

\footnotetext{
${ }^{160}$ Idem.

${ }^{161}$ Ibidem, p. 388.

162 Ibidem, p. 356.

${ }^{163}$ Ibidem, p. 356.
} 
mais esclarecido Heroísmo, quer na Paz, quer na Guerra. Eu o vejo pegar nas armas, e dar a vida com um júbilo extraordinário pela sua Religião, já defendendo-a e já propagando-a (sic) enfim por todos os lados que a examine. Eu não vejo senão um composto de ações brilhantes, uma Nação de Heróis (...) toda a Assembleia está ao fato das brilhantes ações que praticaram, e que os fizeram dignos de respeito no mundo todo e da admiração da posteridade. ${ }^{164}$

Tal elogio aos portugueses em momento tão delicado, em que o antilusitanismo explicita-se na cena pública, incendiaria a Constituinte. Manoel França interromperia o preopinante pedindo para que o presidente lhe chamasse à ordem, já que o mesmo insistia em posicionar-se contra a liberdade religiosa, artigo que já havia sido aprovado pela Assembleia: "Peço a V. Ex. que não deixe voltar a discussão para o que está vencido (Apoiado, Apoiado)”. Silva Lisboa, por sua vez, sairia em defesa de Rodrigues da Costa, afirmando que "requerer tal ordem é desordem" ${ }^{165}$. Em mais uma longa fala, respaldaria o discurso do Bispo Capelão-Mor e repreenderia, mais uma vez, o relator do projeto, Antonio Carlos: “O Sr. Relator disse que nós aqui não éramos Teólogos, mas Políticos. Para que, pois, implicou ele no Projeto a Constituição com a Religião?"166. Voltaria a atacar a França, que "tem passado pelas hórridas tempestades Políticas (...) desde o fatal dia de S. Bartolomeu no Reinado fanático de Luz IX até o assassinato do piedoso Luís XVI"167, e questionava:

Para quê, pois, se vai buscar apoio em a nova Carta Constitucional da França? Ninguém no Império quer se não a sua Cartilha que aprendeu na Escola, e a Liturgia que a Igreja Ordena no culto público, onde, seja servo, ou livre, rico, ou pobre, se vê o espírito da genuína igualdade e dignidade da natureza humana, na Mesa da Comunhão, e na participação dos Sacramentos ${ }^{168}$.

Assim como o padre Rodrigues da Costa, Silva Lisboa rebateria os deputados que louvavam a moral protestante da Inglaterra:

Muito respeito à Inglaterra, quanto mais não fosse, pelas suas Sociedade de Propagação da Bíblia, Civilização dos Africanos e Extinção do tráfico da Escravatura. Porém (sinto dizer) não posso deixar de notar os fatos que não abonam nas classes inferiores a sua moralidade superior a dos Países Católicos. Como não admitem o Sacramento da Confissão para propiciar a

\footnotetext{
164 Idem.

165 Idem.

${ }^{166}$ Ibidem, p. 357.

${ }^{167}$ Ibidem, p. 357-358.

${ }^{168}$ Ibidem, p. 358.
} 
Deus, humilhando-se e mortificando a soberba (raiz de todos os males), ela é o País em que há mais duelos, suicídios e crimes capitais que manifestam desesperação de espírito. Em nenhum País nas classes inferiores há maior número de mulheres perdidas $^{169}$.

Por fim, elogiaria a religião católica e, por desdobramento, Portugal - "Tanto em Portugal, como no Brasil, a Religião Católica tem inspirado heroicas virtudes" -, bem como os Sumos Pontífices, os quais “escritores Ingleses, ainda Protestantes deste Século, têm reconhecido que de duzentos e cinquenta e seis, apenas trinta tem sido notados de graves erros humanos"170. Seria, assim, contraposto por Carneiro de Campos à medida que os discursos transpareciam, cada vez mais, ataques pessoais:

Dói-me, Sr. Presidente, que no Século das Luzes, no Século 19, e no meio desta Assembleia ainda haja quem pretenda combatêlo, quem nos queira reduzir ao tempo em que até era sacrilégio falar no Diabo! O ilustre Deputado que acabou de falar cansouse, acarretou toda a história, trouxe a campo os Pontífices da Igreja Romana e afinal não provou nada porque não podia provar. O mesmo fez o Reverendo Sr. Deputado a quem não ouvi uma só coisa que se fosse atendível. (...) [Rodrigues da Costa] disse que da sua Província tem recebido cartas em que se manifestam receios de se estabelecer na Constituição a Liberdade Religiosa; pois eu digo que não tenho recebido nenhuma que contenha tal ideia, e creio que de tantos ilustres Deputados que se acham neste Recinto nenhum há também que as tenha recebido. Ao contrário, as de que tenho notícia vindas de diversas Províncias, e até da mesma do ilustre Deputado, dizem que muito se estimaria que se aprovassem estes Artigos. ${ }^{171}$

Caetano Lopes Gama, posicionando-se contrário aos artigos, traria um novo argumento de que, estendidos os direitos políticos às comunhões cristãs, dentre em breve protestantes eleger-se-iam para o Parlamento: "eis aqui como o que hoje constituímos porque somos católicos, pode vir a ser destruído por protestantes quando tiverem nossa autoridade" $" 172$. Para o deputado, portanto, aprovar o artigo era aniquilar a religião do Estado. Já o militar Felisberto Brant Pontes, talvez pela sua experiência com a diplomacia, buscaria apaziguar os ânimos da Assembleia, iniciando seu discurso com elogios aos deputados "tanto pró como contra os Artigos", e declarando estar ciente de que o "único fim" dos parlamentares "é o maior bem da Pátria; discorre-se por princípios diferentes,

\footnotetext{
${ }^{169}$ Ibidem, p. 359.

${ }^{170}$ Idem.

${ }^{171}$ Ibidem, p. 359-360.

${ }^{172}$ Ibidem, p. 360.
} 
mas daquele objeto ninguém se separa, e essa uniformidade de pensar há de ser mui vantajosa à nossa Constituição, de que depende a ventura do Brasil (Apoiado)""173.

Louvava que todos os constituintes, sem exceção, concordassem em declarar que a religião do Estado é a católica, “e que com efeito nós não professamos outra, nem queremos outra". O "único lado" que tomaria nessa matéria é o da "utilidade que nos resulta da tolerância de quaisquer Seitas Religiosas" ${ }^{174}$, principalmente porque o Brasil precisava atrair muitos estrangeiros dada a

determinação de acabarmos com o comércio da escravatura, empregada pela maior parte na lavoura, e que é preciso suprir com colonos, e finalmente a necessidade de aumentarmos a nossa população, o que será dificultosíssimo conseguir admitindo somente ao nosso grêmio indivíduos de uma só Religião. Eu fui encarregado nesta minha última viagem de convidar estrangeiros para o Brasil, e posso asseverar perante esta Augusta Assembleia que por toda a parte da Europa achei a melhor disposição nos ânimos dos indivíduos para virem estabelecer-se no nosso país, com a cláusula única de lhes ser garantida constitucionalmente a sua Religião ${ }^{175}$.

Porém, nem toda a diplomacia de Brant Pontes acalmaria os espíritos mais jovens e exaltados, como o de Montesuma, ou os mais velhos e intolerantes, como o de Rodrigues da Costa e Silva Lisboa. Montesuma replicaria diretamente a Rodrigues da Costa, levando ao momento mais tenso de todo o debate sobre a liberdade religiosa. Criticaria com veemência o elogio do mineiro "à conduta dos Portugueses", afirmando estar "convencido que aquelas expressões não foram filhas do seu coração", chegando a ironizá-lo: "Eu quisera saber como o ilustre Reverendo Deputado sabe que o povo não quer, e o que é que não quer" ${ }^{176}$ :

Só se sabe isso particularmente, ou considera o povo do Brasil tão pouco ilustrado que nem entende o sentido dos Artigos, ou se tem tido representações a si dirigidas como Prelado, e a isto chama ter consultado o Brasil todo, concluindo que ele antes não quer admitir em seu seio os Estrangeiros do que conceder-lhes faculdades de darem a Deus o culto que bom lhe parece segundo a sua crença. Eu ao menos não tenho notícia de que haja sobre isso impugnação pelo povo. ${ }^{177}$

\footnotetext{
173 Ibidem, p. 361.

${ }^{174}$ Idem.

${ }^{175}$ Idem.

${ }^{176}$ Ibidem, p. 363.

${ }^{177}$ Ibidem, p. 364.
} 
A seguir, afirmaria que os inimigos da liberdade religiosa não são o povo brasileiro, mas "talvez alguns Padres cheio de superstições, alguns Vigários avarentos que o querem é arrancar do rebanho, se possível for, quantos vinténs este tenha, a título de benesses, a com a capa de culto Divino". Argumentaria que esses vigários não estão zelando pela fé, mas sim preocupados em "aumentar as suas rendas", e que isso muito mal fazia ao clero brasileiro, que também contava com "homens mui dignos e que o honram", sobretudo porque, diferentemente do que acontecia no mundo todo, nas convulsões políticas "é o Clero quem mais tem trabalhado e feito mais esforços a favor da Causa" ${ }^{178}$.

Rodrigues da Costa pedirá ao presidente que o chame à ordem, já que deputado estava atacando uma classe, o clero, ao que Montesuma replicará: "Eu persuado-me que não faço ataque algum ao Clero quando digo alguns Padres Vigários avarentos". Prosseguirá, então, com seu discurso altamente inflamado, o qual o taquígrafo não pôde acompanhar até o final devido a rapidez com que falara. A seguir, Francisco Carneiro e Nicolau Vergueiro defendem que se tolerem todas as religiões e que não haja perseguições por motivos religiosos, porém, mostram-se convencidos de que se deve permitir o culto público apenas aos católicos, reservando-se casas particulares, sem campanários e outros símbolos externos aos templos das demais seitas, apresentando emendas neste sentido ${ }^{179}$. Apesar de nenhum dos dois compor o Conselho de Estado que elaborou a Constituição de 1824, seus argumentos foram integralmente incorporados na Carta Magna, os quais podem ser apreendidos da longa emenda apresentada por Francisco Carneiro à Assembleia:

A Constituição declara que reconhece a Religião Católica Apostólica Romana como a única verdadeira, e, portanto, a Religião do Estado, e única por ele mantida, e a que é permitido o culto particular e público nos Templos e fora deles por toda a extensão do Império. Quanto às outras Religiões e Seitas que por via dos Colonos, ou quaisquer outros Estrangeiros que as professem, e seus descendentes, tenham já, ou possam vir a ter existência no Império, elas serão toleradas e seus Sectários gozarão do livre exercício de seu culto, quer nas casas de sua habitação, quer dentro do recinto dos seus respectivos Templos e Capelas, construídas sem campanários e na forma usada nos países civilizados; nem serão jamais incomodados, ou privados do uso desse direito, com tanto que respeitem a moral pública e o estabelecimento Religioso da Paz, e que a título de Religião e proselitismo não turbem de modo algum a segurança, paz e

\footnotetext{
${ }^{178}$ Idem.

${ }^{179}$ Ibidem, p. 365 e 370.
} 
tranquilidade do Império, e os direitos que a Constituição garante a seus habitantes. ${ }^{180}$

Julgando-se a matéria enfim discutida, passou-se à votação da mesma, bem como de suas inúmeras emendas. Aprovou-se por 57 votos a primeira parte do artigo 14 conforme emenda apresentada por Antonio Carlos, cuja redação era a seguinte: "Cada Membro das Comunhões Cristãs pode professar a sua Religião no recinto destinado para este fim" ${ }^{181}$. A segunda parte do artigo, aprovada por 38 votos, concebia-se nos seguintes termos, segundo emenda apresentada por Nicolau Vergueiro: “É, porém, livre o culto privado de todas as outras que não forem destrutivas da moral" ${ }^{\text {"182 }}$. O artigo 15 , por sua vez, era aprovado "por grande maioria" 183 nos termos da emenda de Antonio Carlos, excluindo-se a sua segunda parte, que tratava dos direitos políticos, por julgá-la deslocada, "reservando-se, portanto, o tratar dessa matéria em lugar apropriado"184. Tal artigo ficava assim definido: “As outras Religiões, além da Cristã, são apenas toleradas, e só lhe compete o culto doméstico"185. Quanto ao artigo 16, foi aprovado, igualmente por "grande maioria" "186, na forma concedida pela emenda também de Antonio Carlos: "A Religião Católica Apostólica Romana é a Religião do Estado, e a única mantida por ele, e só a ela compete o culto externo fora das Igrejas" ${ }^{187}$.

A enorme quantidade de emendas oferecidas aos artigos, inclusive as duas do relator do projeto, são significativas da complexidade e extensão dos debates sobre a matéria. Ao fim e ao cabo, a Assembleia optou por delimitar a questão dos direitos políticos dos professantes de religiões acatólicas, cristãs ou não, em outro momento que nunca chegou a acontecer, devido a sua dissolução em 11 de abril, seis dias após a votação dos artigos. Além do mais, decretou que a religião do Império era a católica, única mantida pelo Estado, permitindo-se o seu culto externo em Igrejas, cabendo às demais comunhões - que não fossem destruidoras da moral - o culto apenas particular, em recinto a isso destinado. Ou seja, transparece na aprovação desses artigos que o catolicismo continuava sendo um importante aspecto da fisionomia da América portuguesa, agora Império do Brasil. A Igreja católica constituía-se, portanto, como um poder indissociável

\footnotetext{
${ }^{180}$ Ibidem, p. 370.

181 Ibidem, p. 330.

182 Ibidem, p. 365.

183 Ibidem, p. 370.

${ }^{184}$ Idem.

185 Ibidem, p. 330.

${ }^{186}$ Ibidem, p. 370.

${ }^{187}$ Ibidem, p. 330.
} 
do Estado e fundamental a ele, entendida como um freio moral aos desvios de conduta e aos excessos da população.

Percebe-se no discurso dos deputados - o que de certa forma transparece na redação final dos artigos - uma preocupação muito grande em atrair estrangeiros úteis ao Brasil, tanto por motivos de povoamento, quanto de substituição da mão de obra escrava. Contudo, o conceito de "estrangeiros úteis" parecia referir-se, exclusivamente, aos protestantes, nomeadamente ingleses e alemães, tantas vezes invocados nos discursos dos deputados. A esses, professantes de comunhões cristãs diversas da católica, caberia o culto particular em casas para isso destinadas, sem forma alguma exterior de templo. Nesse sentido, dava-se continuidade à legislação de 1810 referente aos ingleses, segundo a qual os súditos da Inglaterra que residissem no Brasil não seriam perseguidos e poderiam cultuar a sua religião livremente, desde que sem exterioridade de culto e templos, e sem proselitismo.

Quanto às demais religiões, entre elas o judaísmo, cuja liberdade religiosa havia sido defendida pelo padre Rocha Franco, reservava-se somente a prerrogativa de cultos domésticos, sendo-lhes garantido que não seriam perseguidos ou violentados por suas opiniões religiosas, desde que respeitassem a religião oficial do Império e a tranquilidade e ordem públicas. No mais, não havia sequer um deputado que questionasse a oficialidade do catolicismo no Império do Brasil: nem mesmo aqueles mais radicais como os padres Henriques de Resende e Muniz Tavares, que tantas vezes criticaram os "abusos" da Igreja em seus discursos. O Brasil, aos olhos dos deputados que se pronunciaram sobre o assunto, parecia ser uma nação se não inteiramente, em sua grande maioria formada por católicos. Negligenciavam-se, tanto pelo lado dos liberais conservadores, quanto dos liberais radicais, as religiões de matriz africana, assumindo-se, por sua vez, que não havia, no Brasil, um número expressivo de nacionais protestantes ou sectários de outros credos. O preconceito traduzia-se na recusa em admitir a existência de outras religiões cristãs ou não cristãs entre os nacionais, uma vez que os deputados se consideravam representantes de uma nação inteiramente católica. A liberdade religiosa, nas circunstâncias atuais do país, referia-se quase que exclusivamente à liberdade de culto para os estrangeiros que residiam ou viessem a residir no Brasil.

Porém, apesar de levantar algumas vozes contrárias - como a de Silva Lisboa, Rodrigues da Costa e Maciel da Costa -, a liberdade de culto como direito individual dos brasileiros foi amplamente defendida, até mesmo porque as "Luzes do Século" evidenciavam que a relação da criatura com o seu criador, do indivíduo com o Ente 
Supremo era um santuário onde poder humano nenhum poderia penetrar. Tratava-se, portanto, de convicção íntima e da consciência de cada indivíduo, sobre a qual o Estado não poderia interferir. As mesmas "Luzes do Século" postulavam que ninguém, brasileiro ou estrangeiro, poderia ser perseguido ou violado por seus pensamentos, de forma que no "novo sistema" não havia espaço para a intolerância tal qual acontecia no Antigo Regime e nos tempos sombrios do Tribunal do Santo Ofício. Entretanto, ainda como um resquício do Antigo Regime, a maioria deputados via na religião o fundamento moral da sociedade, um suplemento às leis civis e um verdadeiro "freio" à libertinagem e aos maus costumes da população. Sobretudo aquela população identificada como inculta e incivilizada, reconhecida no enorme contingente de pessoas livres, pobres, negras e mestiças, o contingente dos cidadãos de segunda classe do texto constitucional de 1824. 


\section{Considerações finais}

No dia 24 de agosto de 1820 eclodia no Porto um movimento regenerador e liberal chamado vintismo. Esse movimento chegaria às províncias do Sul de Portugal, tomando Lisboa em 15 de setembro, além de se espalhar para suas possessões ultramarinas, nomeadamente a colônia portuguesa na América, elevada à condição de Reino Unido desde 1815. Aos 26 de fevereiro de 1821, o Rio de Janeiro, sede da Corte desde 1808, aderia ao movimento. Os liberais dos dois lados do Atlântico identificavam nas práticas absolutistas e despóticas os males que deveriam combater, caminhando, enfim, para as “Luzes do século". Tornava-se cada vez mais impraticável uma administração nos moldes até então praticados pela Coroa lusa. "Cortes e Constituição" transformaram-se, então, nos símbolos mágicos que resolveriam toda a crise portuguesa.

Em Portugal e no Brasil, porém, nem todas as estruturas e tradições do Antigo Regime foram deslegitimadas naquele momento, optando-se por uma alternativa verdadeiramente moderada, antes regeneradora e reformista do que revolucionária. $\mathrm{Na}$ década de 1820, pairava sobre a Europa a ação/reação restauradora da Santa Aliança, procurando restabelecer, pautada nos princípios da legitimidade e hereditariedade, as monarquias atingidas pelo radicalismo revolucionário de finais do século XVIII. Além do mais, a fase do terror e os "excessos de liberdade" advindos da Revolução Francesa tinham deixado suas marcas indeléveis na memória social e ainda assombravam o imaginário das elites da época. Por tudo isso, entendemos que as "Luzes" portuguesas se revelaram de forma mitigada e/ou incompleta, conciliando elementos da modernidade como Cortes, Constituição e representação nacional - com práticas, tradições e liturgias típicas do antigo sistema - nomeadamente a manutenção da monarquia, da escravidão e da autoridade e influência da Igreja.

Nesse sentido, a pesquisa mostrou-nos que as modernas (res)significações das "palavras de ordem do Oitocentos", como voto, representação, cidadania e liberdade conviviam com antigos modos de pensar e de agir, especificamente a escravização dos negros, a importância da liturgia da Igreja católica e a força simbólica do monarca. É por isso que os liberais do lado de lá do Atlântico, com vistas a recuperar a antiga hegemonia da metrópole no interior do Império luso, reivindicaram a volta imediata de d. João VI para Lisboa, identificando o despotismo muito mais nos "ministros inescrupulosos" que o aconselhavam mal do que no próprio soberano. Se na França revolucionária o monarca 
e sua família foram enviados à guilhotina, em Portugal e no Brasil, ao contrário, o rei era um símbolo que assegurava a tranquilidade, ordem e felicidade pública, percebido como um verdadeiro "pai” capaz de guiar a sua nação para a "bem entendida e justa" liberdade, para o progresso, enfim, para inserir o Império luso no rol das civilizações modernas.

Verificamos, ainda, que a questão da sede da monarquia foi o início de uma série de divergências que, lenta e gradativamente, distanciaria os dois povos "irmãos", marcando uma diferenciação, cada vez maior, entre portugueses europeus e portugueses americanos. Do princípio do movimento vintista até meados de 1821, os liberais dos dois lados do Atlântico não defendiam a separação entre a metrópole e sua principal e maior colônia. O ideal do grande Império luso-brasileiro ainda estava muito presente no imaginário das elites políticas da época, treinadas e homogeneizadas pela reformada Universidade de Coimbra, de forma que partilhavam uma cultura política comum. Muito embora os valores, práticas, símbolos e normas dessa cultura política não se expressassem de forma única e idêntica para todos os membros da elite, ocorria um compartilhamento de visão de mundo, comprometida com o fim dos entraves coloniais para, assim, liquidar quaisquer movimentos sediciosos como aqueles ocorridos no Brasil no final do Setecentos. Essa elite, portanto, foi fundamental para empreender reformas educacionais, militares, técnicas e administrativas na colônia durante o governo joanino, sem, contudo, defender a separação da metrópole, principal "ponte" que ligava o Brasil às grandes civilizações europeias.

Porém, uma vez instauradas as Cortes Gerais de Lisboa em janeiro de 1821 sem contar com uma deputação do além-mar, e aprovados decretos "recolonizadores", ganharia forma e adeptos a solução separatista. Tais decretos, datados de 29 de setembro daquele ano, buscavam cercear a autonomia alcançada pelo Brasil desde 1815, quando fora elevado a Reino Unido: extinguiam os tribunais superiores em território brasileiro, subordinavam suas províncias à Lisboa e ordenavam o retorno do príncipe regente à Portugal - e, portanto, são considerados "recolonizadores" pela historiografia brasileira da Independência. A chegada das notícias dos decretos no Rio de Janeiro gerou um verdadeiro clima de guerra entre os portugueses residentes na cidade e os brasileiros, que se sentiam ludibriados e enganados pelos liberais vintistas. Antes mesmo de reivindicarem a separação formal de Portugal, os defensores da chamada "causa do Brasil” pressionavam para que não só d. Pedro ficasse na América, mas que fosse criada uma "Assembleia brasílica” para estabelecer o melhor "regulamento" para o país. 
Agindo de forma cada vez mais independente, d. Pedro assume o posto de protagonista da Independência do Brasil, tomando à frente dos principais acontecimentos daquele momento. Conseguiria, por fim - a duras penas e contando com o auxílio de seu principal ministro, José Bonifácio de Andrada e Silva -, unir as províncias do Brasil em torno de um elo comum: o projeto de uma monarquia constitucional, cujo centro de poder seria o Rio de Janeiro, mas que, graças à convocação de uma Assembleia, contaria com representantes de quase todas as províncias brasileiras. Essa Assembleia Geral, Legislativa e Constituinte seria responsável por estabelecer o ordenamento jurídico e elaborar a Constituição do nascente Império.

A pesquisa empírica permitiu-nos concluir que, apesar de sua dissolução violenta, a mando do próprio Imperador, a importância da Assembleia Constituinte de 1823 é historicamente inquestionável. Os trabalhos dos deputados constituintes, membros das elites políticas da época, foram atentamente acompanhados pelo "povo", pelo menos no que diz respeito à população fluminense: cartas e petições eram enviadas diariamente à Assembleia, jornais e periódicos noticiavam as decisões e discussões do Plenário e os populares se aglomeravam nas galerias da Cadeia Velha para vigiar a conquista ou não de direitos e garantias fundamentais.

Quanto aos deputados constituintes, a "ilha de letrados no mar de analfabetos", pode-se dizer que todos, sem exceção, professavam um liberalismo mais ou menos avançado. Vencidos os arroubos autoritários e absolutistas da comitiva reacionária de d. João - cujo maior expoente será o ministro Vilanova Portugal -, devidamente despachada para Portugal, não restará outra alternativa às elites políticas a não ser a assimilação e defesa do espectro político do liberalismo, sem dúvida constitucionalista. Aprendemos dos/nos discursos dos deputados inúmeras críticas ao antigo sistema, ao despotismo e absolutismo, que representavam os entraves do passado que deveriam ser superados com a modernidade e com as "Luzes" do século.

Entretanto, com relação especificamente à questão da soberania, verificamos algumas nuances importantes capazes de definir dois "níveis" dentro do campo político do liberalismo. Em primeiro lugar, agrupam-se os que chamamos de "liberais radicais". Inspirados nos princípios do abade Sieyès, constituinte francês de 1789, defendiam uma monarquia na qual a nação, representada por uma Assembleia legitimamente eleita por voto popular, detinha a soberania absoluta, de forma que ao monarca caberia apenas o papel de executor das leis. Para os liberais radicais, portanto, prevaleceria a legitimidade do Legislativo sobre o Executivo. Já o grupo dos "liberais conservadores", por sua vez, 
inspirava-se nas ideias monarquianas defendidas por Mournier. Nesse sentido, embora admitissem a soberania nacional como princípio de legitimidade da ordem pública, atribuíam ao Executivo o papel de guardião dos interesses nacionais, a quem caberia o direito de veto às decisões da Assembleia. A soberania, portanto, antes de residir na nação, residiria no rei, aclamado pela mesma. Houve, também, uma terceira via: a possibilidade de trânsito entre esses dois extremos do espectro político do liberalismo, de forma que surgiram, no âmbito da Assembleia, posições conciliadoras e mediadoras entre os dois "níveis".

A discussão da liberdade religiosa na Constituinte de 1823 é significativa dessas correntes atuantes dentro do campo político do liberalismo. Do lado dos radicais, localizamos deputados como os padres Muniz Tavares, Henriques de Resende e Custódio Dias, além do baiano Montesuma. São, no geral, mais jovens, além de possuírem experiência revolucionária (principalmente na Revolução de 1817) e de procederem de províncias do Nordeste, como Pernambuco e Bahia, cuja maior proximidade com os Estados Unidos da América, segundo Evaldo Cabral de Mello, proporcionou um maior trânsito de ideias republicanas a radicais. Destaca-se também, dentro dessa corrente, a presença de membros do clero que, apesar de sua condição eclesiástica, criticam os abusos da Igreja e são mais afeitos aos "ímpios livros franceses" do que aos ditames da Cúria Romana. Nesse sentido, para João Fagundes Hauck, seriam antes funcionários do Estado do que da Igreja, de forma que não houve, por parte de parcela do clero nacional, preocupação em aumentar o domínio espiritual desta no domínio temporal daquele.

Já os deputados identificados com uma orientação mais conservadora do liberalismo foram Maciel da Costa, Carneiro de Campos, Silva Lisboa e o padre Rodrigues da Costa. No geral, eram deputados mais velhos (os dois últimos contavam mais de 60 anos em 1823) que temiam os "excessos de liberdade" e toda a sorte de libertinagem e perturbação da ordem. À exceção de Carneiro de Campos - o grande teórico do Poder Moderador que, contudo, articulou o discurso mais liberal na Constituinte acerca da liberdade religiosa, aproximando-se da defesa de um Estado laico -, os liberais conservadores escandalizavam-se com a possibilidade de instituir-se a liberdade de culto como um direito individual dos brasileiros. Deixando claro que não consentiam com perseguições e violências por motivo religioso, acreditavam ser esse um direito não demandado pela população brasileira, formada inteiramente por católicos romanos. Além do mais, acreditavam que a religião católica representava um importante suplemento às leis civis, já que funcionava como uma espécie de "freio" às libertinagens 
e intenções criminosas. Para eles, portanto, a religião católica era o fundamento moral e civilizador da sociedade brasileira, tão inculta e atrasada.

Ainda com relação à liberdade religiosa, observamos que a posição conciliadora e moderada sairia vitoriosa. Defendida por deputados como Antonio Carlos e Carneiro da Cunha - ambos cinquentenários, a faixa etária majoritária na Assembleia -, essa posição praticamente traduzia a cultura política partilhada pelas elites políticas da Independência. Nesse sentido, conciliavam-se antigos e novos modos de pensar e de agir, modernidade e tradição. Admitia-se a liberdade religiosa como direito individual dos brasileiros (Art. $7^{\circ}$, $\S 3^{\circ}$ ), inspirando-se na moderna acepção de que a consciência do indivíduo é um santuário impenetrável pelo poder do Estado, ou seja, que a relação entre a criatura e o criador é de foro íntimo e particular de cada um. Porém, quando em votação os artigos 14, 15 e 16, que definiam os limites dessa liberdade religiosa, prevaleceram a influência das práticas e liturgias da Igreja católica, ainda inseridas na mentalidade típica do Antigo Regime. Em primeiro lugar, mesmo aqueles favoráveis à liberdade de culto não se mostravam prontos, ainda, para abdicar da condição de súditos de uma nação católica. Não se cogita a possibilidade de um Estado laico, ou pelo menos não se admite a possibilidade de um Estado onde há a falta total de religião, nas palavras de Carneiro de Campos ${ }^{1}$. Na visão da maioria dos deputados, era "essencial que um espírito verdadeiramente religioso anime toda a Nação",2, sendo a verdadeira e única religião a católica, culto por excelência do Império brasileiro e único mantido por ele (Art. 16).

Em segundo lugar, a visão majoritária da Assembleia criou uma hierarquização entre as religiões, já que se estendia a liberdade religiosa apenas às comunhões cristãs. $\mathrm{O}$ culto externo e em Igrejas e templos reservava-se unicamente à religião católica. Já os praticantes das demais comunhões cristãs poderiam professar seu culto em casas para isso destinadas, sem forma exterior de templo (Art. 14). Na prática, mantinha-se o estabelecido desde 1810 com relação aos protestantes ingleses, estendendo tal permissão aos demais cristãos estrangeiros que viessem a se instalar no país. Em nossa percepção, esse dispositivo abrangia a lógica pragmática e utilitarista dos deputados brasileiros, comprometidos em atrair imigrantes "úteis" ao país, seja por substituição futura de mão de obra escrava, seja por motivos de ocupação do vasto território brasileiro. Quanto às demais religiões não cristãs, muitas vezes denominadas "seitas" e "idolatrias" pelos

\footnotetext{
${ }^{1}$ Diário da Assembleia Geral, Legislativa e Constituinte do Império do Brasil (1823). Brasília: Senado Federal, 2003, t. III, p. 197.

2 Idem.
} 
deputados, definiu-se que seriam "apenas toleradas", sendo livre o culto doméstico daquelas que não fossem "destrutivas da moral" (Art. 15).

Levando-se em conta que vários deputados louvaram o fato de não haver, no seio da família brasileira, uma só religião que não fosse a católica, inferimos que as "demais religiões" citadas pelo Art. 15 referem-se especificamente ao islamismo e judaísmo, já que os constituintes ignoravam completamente a existência de religiões de matriz africana no Brasil. Sob essa ótica, tais religiões certamente enquadrar-se-iam no rol de cultos "destrutivos da moral" e dos bons costumes, muito provavelmente por serem largamente praticadas por escravos, e talvez por esse motivo foram tão perseguidas nos anos seguintes.

Por último, não se pode negar que a dissolução violenta da Assembleia em 12 de novembro de 1823 encerrava tragicamente a primeira experiência parlamentar brasileira. Do interior da Cadeia Velha, sitiada pelas tropas leais ao Imperador, saíram pacificamente os deputados, alguns, como os irmãos Andradas, sendo presos e exilados. Quatro meses depois, o Conselho de Estado convocado por d. Pedro para redigir uma Constituição "duplicadamente mais liberal" oferecia uma Carta para ser outorgada pelo Imperador aos 24 de março de 1824. Segundo essa lei fundamental, a religião oficial do Império continuaria sendo a católica, única mantida pelo Estado, e as demais religiões seriam "permitidas com seu culto doméstico, ou particular, em casas para isso destinadas, sem forma alguma exterior de Templo"3. Além do mais, ficavam privados dos direitos políticos os praticantes de religiões acatólicas - matéria que a Assembleia não teve tempo hábil para discutir antes de sua dissolução - e garantia-se a continuidade do padroado régio, reforçando o regalismo e a ingerência do Estado nos assuntos da Igreja, tradição herdada de Portugal

Finalmente, com a dissolução da Constituinte, as "mitigadas Luzes" portuguesas, responsáveis pela dinâmica das transformações políticas ocorridas no Brasil entre 1820 e 1824, davam lugar ao que se pode chamar de "mitigado absolutismo" praticado por d. Pedro. Absolutismo porque, à semelhança do Antigo Regime, fazia uso da força militar para dissolver uma Assembleia legitimamente eleita pelo povo e outorgar uma Constituição, deslegitimando a representação nacional e o poder Legislativo. Absolutismo também porque perseguiu e exilou vozes contrárias a seu governo, além de censurar periódicos que se destinassem a esse fim, como foi o caso do jornal $O$ Tamoio,

\footnotetext{
${ }^{3}$ BRASIL. Constituição (1824). Outorgada pelo Imperador d. Pedro I em 25 de março de 1824. Disponível em: http://www.planalto.gov.br/ccivil_03/Constituicao/Constituicao24.htm. Acesso: 16/05/2016.
} 
editado por Vasconcellos de Drummond, amigo íntimo dos Andradas. Para se usar as palavras de José Honório Rodrigues", a "revolução" da Independência do Brasil, articulada a partir de um liberalismo limitado, trazia consigo os germes da “contrarrevolução", empenhada em frear os espíritos mais liberais.

${ }^{4}$ RODRIGUES, José Honório. Independência: revolução e contra-revolução. A evolução política. v. 1. Rio de Janeiro: Francisco Alves, 1975 


\section{Referências bibliográficas}

\section{Fontes:}

BLAKE, Augusto Vitorino Sacramento. Dicionário bibliográfico brazileiro. Rio de Janeiro: Typographia Nacional, 1883. 7 volumes.

BRASIL. Atas do Conselho de Estado. Conselho dos Procuradores Gerais das Províncias do Brasil, 1822-1823. (Direção: José Honório Rodrigues). Brasília: Senado Federal, 1973.

BRASIL. Diário da Assembleia Geral, Legislativa e Constituinte do Império do Brasil (1823). 3 tomos (edição fac-símile). Brasília: Senado Federal, 2003.

Cartas Andradinas. Correspondência particular de José Bonifácio, Martim Francisco e Antonio Carlos dirigida a A. de M. Vasconcellos de Drummond. Rio de Janeiro: Anais da Biblioteca Nacional do Rio de Janeiro, 1890.

CARVALHO, José Murilo de; NEVES, Lúcia Maria B. Pereira das; BASILE, Marcelo (orgs.). Guerra literária: panfletos da Independência (1820-1823), 4 v. Belo Horizonte: UFMG, 2014. Documentos para a História da Independência, v. 1 (Lisboa - Rio de Janeiro). Rio de Janeiro: Oficinas Gráficas da Biblioteca Nacional, 1923.

LIMA JÚNIOR, Augusto de. Cartas de d. Pedro a d. João VI relativas à Independência do Brasil. Rio de Janeiro: Jornal do Comércio, 1941.

LIMA SOBRINHO, Barbosa. Antologia do Correio Braziliense. Rio de Janeiro: Cátedra; Brasília: Instituto Nacional do Livro, 1977.

MELLO, F. I. Marcondes Homem de. A Constituinte perante a História (1862). Brasília: Senado Federal, 1996.

\section{Bibliografia:}

ALEXANDRE, Valentim. "O nacionalismo vintista e a questão brasileira: esboço de análise política”. In: PEREIRA, Miriam Helpern; FERREIRA, Maria de Fátima Sá e Melo; SERRA, João 
B. (coords.). O Liberalismo na Península Ibérica na primeira metade do século XIX, v. 1. Lisboa: Sá da Costa, 1982, p. 287-307.

BAKER, Keith Michael. "Soberania”. In: FURET, François; OZOUF, Mona (orgs.). Dicionário Crítico da Revolução Francesa. São Paulo: Nova Fronteira, 1989, p. 882-895.

BARROS, Roque Spencer M. de. "Vida religiosa". In: HOLANDA, Sérgio Buarque de; CAMPOS, Pedro Moacyr (dirs.). História Geral da Civilização Brasileira. O Brasil Monárquico. Declínio e queda do Império, t. II, v. 4. $2^{\text {a }}$ ed. São Paulo: Difusão Europeia do Livro, 1974, p. 316-337.

BASILE, Marcelo. "Deputados da Regência: perfil socioprofissional, trajetórias e tendências políticas". In: CARVALHO, José Murilo de; CAMPOS, Adriana Pereira (orgs.). Perspectivas de cidadania no Brasil Império. Rio de Janeiro: Civilização Brasileira, 2011, p. 87-122.

BERNSTEIN, Serge. "Culturas políticas e historiografia”. In: AZEVEDO, Cecília [et al.] (orgs.). Cultura política, memória e historiografia. Rio de Janeiro: Editora FGV, 2009, p. 29-46.

BETHEL, Leslie. “O Brasil no século XIX: parte do 'império informal britânico'?”. In: CARVALHO, José Murilo de; CAMPOS, Adriana Pereira. (orgs.). Perspectivas de cidadania no Brasil Império. Rio de Janeiro: Civilização Brasileira, 2011, p. 15-36.

BOURDIEU, Pierre. O campo político. In: Revista Brasileira de Ciência Política, nº 5. Brasília: julho de 2011, 193-216.

Razões práticas: sobre a teoria da ação. $9^{a}$ ed. Campinas: Papirus, 1996.

CABRAL, Flávio José Gomes. Os patriotas. Pernambuco foi palco da primeira República do país. In: Revista de História, novembro de 2009, s/ página.

CARVALHO, José Murilo; NEVES, Lúcia M. Bastos Pereira das; BASILE, Marcello (orgs.). Às armas cidadãos. Panfletos manuscritos da Independência do Brasil. São Paulo: Companhia das Letras, 2012.

CARVALHO, José Murilo de. “A involução da participação eleitoral no Brasil: 1821-1930”. In: CARVALHO, José Murilo de; CAMPOS, Adriana Pereira (orgs.). Perspectivas de cidadania no Brasil Império. Rio de Janeiro: Civilização Brasileira, 2011, p. 37-58. 
A construção da ordem: a elite política imperial. Brasília: UnB, 1981.

CARVALHO, Manuel E. Gomes de. Os deputados brasileiros nas Cortes Gerais de 1821. (1912) Brasília: Senado Federal, 1979.

CINTRA, Francisco Assis. O homem da Independência: história documentada de José Bonifácio, do seu pseudo-patriarcado e da política do Brasil em 1822. São Paulo: Companhia Melhoramentos, 1921.

CORDEIRO, Cecília Siqueira. A liberdade religiosa na Assembleia Constituinte de 1823. Monografia de final de curso. Universidade de Brasília, Brasília, 2013.

COSTA E SILVA, Alberto da (coord.). Crise colonial e Independência: 1808-1830, v. 1. Rio de Janeiro: Objetiva, 2011 (Coleção História do Brasil Nação: 1808-2010, dir. SCHWARTZ, Lilia Moritz)

COSTA, Emília Viotti da. "Introdução ao estudo da Emancipação Política do Brasil". In:

Da Monarquia à República: momentos decisivos. 9ª ed. São Paulo: Editora UNESP, 2010.

. "José Bonifácio: homem e mito". In: MOTA, Carlos Guilherme (org.). 1822: dimensões. São Paulo: Perspectiva, 1972, p. 102-159.

DIAS, Maria Odila Leite da Silva. “A interiorização da metrópole”. In: . A interiorização da metrópole e outros estudos. $2^{\text {a }}$ ed. São Paulo: Alameda, 2005, p. 7-38.

. "Aspectos da ilustração no Brasil". In: DIAS, Maria Odila Leite da Silva. A interiorização da metrópole e outros estudos. $2^{\text {a }}$ ed. São Paulo: Alameda, 2005, p. 39-126.

FALCÓN, Francisco C.;MATTOS, Ilmar R. de. "O Processo de Independência no Rio de Janeiro". In: MOTA, Carlos Guilherme (org.). 1822: dimensões. São Paulo: Perspectiva, 1972, p. 292-339.

FEITOSA, Pedro Barbosa de Souza. "Que venha o Teu Reino": estratégias missionárias para a inserção do protestantismo na sociedade monárquica (1851-1874). Dissertação (Mestrado em História). Universidade de Brasília, Brasília, 2012. 
FURET, François. “Antigo Regime”. In: FURET, François; OZOUF, Mona (orgs.). Dicionário Crítico da Revolução Francesa. São Paulo: Nova Fronteira, 1989, p. 621-631.

HAUCK, João Fagundes. “Quarto período: a Igreja na emancipação (1808-1840)”. In: et al. História da Igreja no Brasil. Ensaio de interpretação a partir do povo. Segunda Época: A Igreja no Brasil no século XIX. Petrópolis: Editora Vozes, 1980.

HOLANDA, Sérgio Buarque de. Raízes do Brasil. 26a ed. São Paulo: Companhia das Letras, 1995.

HOLANDA, Sérgio Buarque de; CAMPOS, Pedro Moacyr (dirs.). História Geral da Civilização Brasileira. O Brasil Monárquico. O processo de emancipação, t. II, v. 1. $4^{\text {a }}$ ed. São Paulo: Difusão Europeia do Livro, 1974.

JANCSÓ, István; PIMENTA, João Paulo G. Peças de um mosaico ou apontamentos para o estudo da emergência da identidade nacional brasileira. In: Revista de História das Ideias, vol. 21, 2000, p. $389-440$.

KIRSCHNER, Tereza Cristina. José da Silva Lisboa, visconde de Cairu. Itinerários de um ilustrado luso-brasileiro. São Paulo: Alameda; Belo Horizonte: PUC-Minas, 2009.

Um pouco de historiografia: a representação do passado colonial brasileiro a partir da Independência. In: Anais do XXVI Simpósio Nacional de História - ANPUH. São Paulo, julho de 2011, 1-33.

KOSELLECK, Reinhart. “'Espaço de experiência' e 'horizonte de expectativa': duas categorias históricas". In: Futuro passado: contribuição à semântica dos tempos históricos. Rio de Janeiro: Contraponto/PUC-Rio, 2006, p. 305-328.

LEITE, Renato Lopes. Republicanos e libertários: pensadores radicais no Rio de Janeiro (1822). Rio de Janeiro: Civilização Brasileira, 2000.

LUSTOSA, Isabel. "O debate sobre os direitos do cidadão na imprensa da Independência". In: RIBEIRO, Gladys Sabina; FERREIRA, Tânia Maria Tavares Bessone da Cruz. (orgs.). Linguagens e práticas da cidadania no século XIX. São Paulo: Alameda, 2010, p. 11-24. 
LYNCH, Christian Edward. "A vocação sociológica do legislador: o pensamento político do Marquês de Caravelas". In: RIBEIRO, Gladys Sabina (org.). Brasileiros e cidadãos: modernidade política, 1822-1930. São Paulo: Alameda, 2008, p. 149-174.

LYRA, Maria de Lourdes Viana. A unidade brasileira: uma questão preliminar no processo de Independência. In: Revista do Instituto de Estudos Brasileiros, vol. 34. São Paulo, 1992, p. 121138.

MATTOS, Ilmar Rohloff. O tempo saquarema: a formação do Estado Imperial. $2^{\text {a }}$ ed. São Paulo: Haucitec, 1990.

MAXWELL, Kenneth. “A geração de 1790 e a ideia do império luso-brasileiro". In:

Chocolate, piratas e outros ensaios tropicais. Rio de Janeiro: Paz e Terra, 1999, p. 157-207

MELLO, Evaldo Cabral de. A outra Independência. O federalismo pernambucano de $1817 \mathrm{e}$ 1824. São Paulo: Editora 34, 2004.

MOTA, Carlos Guilherme (org.). 1822: dimensões. São Paulo: Perspectiva, 1972.

NEVES, Guilherme Pereira das. "A religião do império e a Igreja". In: GRINBERG, Keila; SALLES, Ricardo (orgs.). O Brasil Imperial, volume I: 1808-1831. Rio de Janeiro: Civilização Brasileira, 2009, p. 377-428.

NEVES, Lúcia M. Bastos Pereira das. "Constituição: usos antigos e modernos de um conceito no Império do Brasil". In: CARVALHO, José Murilo de; NEVES, Lúcia M. Bastos Pereira das (orgs.). Repensando o Brasil do Oitocentos: cidadania, política e liberdade. Rio de Janeiro: Civilização Brasileira, 2009, p. 181-205.

. "O governo de D. João: tensões entre ideias liberais e as práticas do Antigo Regime". In: CARVALHO, José Murilo de; CAMPOS, Adriana Pereira. Perspectivas de cidadania no Brasil Império. Rio de Janeiro: Civilização Brasileira, 2011, p. 203-226.

Corcundas e constitucionais: a cultura política da Independência (1820-1822). Rio de Janeiro: Revan/FAPERJ, 2003. 
OLIVEIRA, Cecília Helena L. de Salles. "Repercussões da revolução: delineamento do império do Brasil, 1808/1831". In: GRINBERG, Keila; SALLES, Ricardo (orgs.). O Brasil Imperial, volume I: 1808-1831. Rio de Janeiro: Civilização Brasileira, 2009, p. 15-54.

“Estado, nação e escrita da História: propostas para debate". In: CARVALHO, José Murilo de; NEVES, Lúcia M. Bastos Pereira das (orgs.). Repensando o Brasil do Oitocentos: cidadania, política e liberdade. Rio de Janeiro: Civilização Brasileira, 2009, p. 239-266.

A astúcia liberal. Relações de mercado e projetos políticos no Rio de Janeiro (18201824). Bragança Paulista: EDUSF/Ícone, 1999.

PEREIRA, Nilo. Conflitos entre a Igreja e o Estado no Brasil. $2^{\mathrm{a}}$ ed. Recife: Editora Massangana, 1982.

OLIVEIRA, Miguel de. História Eclesiástica de Portugal. 2ª ed. Lisboa: União Gráfica, 1948.

PEREIRA, Vantuil. “A longa "noite da agonia”". In: Revista de História, janeiro de 2012, s/ página.

PIRES, Heliodoro. Temas de História Eclesiástica do Brasil. São Paulo: São Paulo Editora S/A, 1946.

PRADO JÚNIOR, Caio. "O Tamoio e a Política dos Andradas na Independência do Brasil”. In: . A evolução política do Brasil e outros estudos. 12a ed. São Paulo: Brasiliense, 1980, p. 180-190.

REIS, João José; SILVA, Eduardo. Negociação e conflito: a resistência negra no Brasil escravista. São Paulo: Companhia das Letras, 1989.

RIBEIRO, Gladys Sabina. "Nação e cidadania no jornal O Tamoio. Algumas considerações sobre José Bonifácio, sobre a Independência e sobre a Constituinte de 1823”. In: . (org.). Brasileiros e cidadãos: modernidade política, 1822-1930. São Paulo: Alameda, 2008, p. 37-64.

RIBEIRO Gladys Sabina; PEREIRA, Vantuil. "O Primeiro Reinado em revisão". In: GRINBERG, Keila; SALLES, Ricardo (orgs.). O Brasil Imperial, volume I: 1808-1831. Rio de Janeiro: Civilização Brasileira, 2009, p. 137-174. 
RODRIGUES, José Honório. A Assembleia Constituinte de 1823. Petrópolis: Editora Vozes, 1974.

RODRIGUES, José Honório. Independência: revolução e contra-revolução. A evolução política. v. 1. Rio de Janeiro: Francisco Alves, 1975.

Independência: revolução e contra-revolução. As forças armadas, v. 3. Rio de Janeiro: Biblioteca do Exército, 2002.

SCHAWRCZ, Lilia M.; STARLING, Heloisa M. Brasil: uma biografia. São Paulo: Companhia das Letras, 2015.

SILVA, M. Beatriz Nizza da. A repercussão da revolução de 1820 no Brasil: eventos e ideologias. In: Revista de História das Ideias, v. 2 (1978-1979), p. 1-52.

SOUZA, Octávio Tarquínio de. História dos Fundadores do Império do Brasil, vol. 1 (A vida de José Bonifácio), 2a ed. Rio de Janeiro: José Olympio, 1957.

História dos Fundadores do Império do Brasil, vol. 2 (A vida de d. Pedro I), 2 tomos, $3^{\mathrm{a}}$ ed. Rio de Janeiro: José Olympio, 1957.

TOMAZ, Fernando. "Brasileiros nas Cortes constituintes de 1821-1822". In: MOTA, Carlos Guilherme (org.). 1822: dimensões. São Paulo: Perspectiva, 1972, p. 74-101.

WEREBE, Maria José Garcia. "A Educação”. In: HOLANDA, Sérgio Buarque de; CAMPOS, Pedro Moacyr (dirs.). História Geral da Civilização Brasileira. O Brasil Monárquico. Declínio e queda do Império, t. II, v. 4. $2^{a}$ ed. São Paulo: Difusão Europeia do Livro, 1974, p. 366-383. 